\author{
Jorge Luiz Rabelo
}

\title{
ESTUDO DA RECARGA DO AQÜÍFERO GUARANI NO SISTEMA JACARÉ-TIETÊ
}

Tese apresentada à Escola de Engenharia de São Carlos da Universidade de São Paulo, como parte dos requisitos para a obtenção do Título de Doutor em Engenharia Civil (Hidráulica e Saneamento).

Orientador: Prof. Dr. Edson Cezar Wendland

São Carlos

(2006) 
Dedico este trabalho em homenagem a três grandes mulheres, admiráveis pelo exemplo de força e generosidade: Carminha, minha mãe-de-criação, Mara, minha irmã, e Alvaceli, minha esposa. 


\section{AGRADECIMENTOS}

Ao Prof. Edson Wendland, pela grande colaboração e presteza na orientação deste trabalho.

À CAPES e à FAPESP, pelo apoio financeiro.

Aos professores do SHS, em especial aos Profs. Fazal Chaudhry e Rodrigo Porto, e ao Prof. Lázaro Zuquette, do SGS, pelo apoio e incentivo.

Às funcionarias do SHS, Fernanda, Flávia, Pavi e Sá, pelo indispensável apoio técnico.

À Diretoria do comitê de bacia CBH-TJ, em especial ao Eng. Braz Passalacqua, e aos técnicos do DAEE-Araraquara, em especial ao Geo. Luiz Galvão e Engs. Reinaldo Passerini, José Teixeira, Paulo Luiz e Milton Silva, pela inestimável colaboração no acesso e levantamento de dados.

Ao Geo. Urandi Corrêa, por ceder gentilmente informações e dados de grande valia sobre a área de estudo.

Aos colegas do LHC, em espacial a Quaresma, Anderson, Mariano, Carlos, Luis, Marcelo, Fábio e Francisco pela troca de conhecimentos e profícua amizade constituída.

Aos meus familiares e amigos que me apoiaram, incentivaram ou simplesmente emprestaram, em algum momento, a convivência da qual retirei traços que me acompanham e me influenciam profissionalmente:

Renato Rabelo (em memória), Maria de Brotas (em memória) e Carminha, José Renato, Antônio (Tito), Agnaldo (Mundo, em memória), Mara, Corro e Lena, Conchita e Maria Pinheiro, João Moura e Hans Schuster.

Às minhas filhas, Gabriela, pela colaboração e compreensão, e Laís, além disso, pelo apoio gráfico.

À minha esposa, Alvaceli, pela resistência às dificuldades encontradas e por compactuar com os propósitos deste trabalho, agradeço sinceramente. 


\section{RESUMO}

RABELO, Jorge Luiz. (2006). Estudo da recarga do Aqüifero Guarani no sistema Jacaré-Tietê. Tese (Doutorado) - Escola de Engenharia de São Carlos, Universidade de São Paulo, São Carlos, 2006.

Este trabalho visa avaliar a recarga e o sistema de fluxo do Aqüifero Guarani com o auxílio de um modelo numérico, aplicado à área delimitada pelas bacias hidrográficas dos rios Jacaré-Guaçú e Jacaré-Pepira (sub-bacias do Rio Tietê, na região central do Estado de São Paulo, Brasil). Com este fim, foi estabelecido um modelo conceitual para o sistema de escoamento subterrâneo. Técnicas em SIG foram utilizadas no armazenamento, processamento e análise de dados levantados em intensa revisão bibliográfica, bem como, gerados mapas com as características dimensionais e hidrogeológicas. Os fenômenos hidrológicos mais significativos foram selecionados, resultando na construção do modelo conceitual para estimativa de fluxo e recarga do aqüífero, que possui na área de estudo significativa extensão de afloramento. Foram atribuídas seis zonas de recarga correspondentes a formações e estruturas geológicas que compõem o aqüifero semiconfinado e livre. O modelo foi calibrado pelas vazões de base, obtidas de hidrogramas diários, e pelos níveis estáticos de poços. Uma análise de sensibilidade foi realizada envolvendo os parâmetros de ajuste da calibração. Os resultados mostram existir interação entre as recargas do aqüifero, provenientes das duas bacias, e indicam que o aqüífero essencialmente drena a sua recarga através dos rios. Os fluxos laterais (fluxo subterrâneo entre bacias), a descarga profunda e a explotação por poços representam pequenas saídas em comparação à recarga total, contudo, a ação dos poços apresenta efeitos com alguma tendência regional no entorno dos maiores centros urbanos da área de estudo. A determinação das vazões de base identificou os trechos ao longo dos rios nos quais o aqüífero os carrega e é carregado. Apesar do aqüífero essencialmente abastecer os rios, os trechos nos quais os rios o carregam são significativos e importantes por serem trechos nas quais o aqüifero é potencialmente mais vulnerável.

Palavras-chave: Aqüífero Guarani; recarga de aqüífero; modelo de fluxo 


\section{ABSTRACT}

RABELO, Jorge Luiz. (2006). Study of the Guarani Aquifer recharge in JacaréTietê system. Ph.D. Thesis. - Escola de Engenharia de São Carlos, Universidade de São Paulo, São Carlos, 2006.

This work aims to assess the recharge and flow system of the Guarani Aquifer with the aid of a numeric model, applied to the area delimited for the hydrographic basins of the rivers Jacaré-Guaçú and Jacaré-Pepira (sub-basin of the Tietê River, in the central region of São Paulo State, Brazil). Thus, a conceptual model for groundwater flow system was established. GIS based tools was used in the storage, processing and analysis of data raised in intense bibliographical revision as well as generated maps with the dimensional and hydrogeologic characteristics. Main hydrologic phenomena were selected, leading to a groundwater conceptual model for evaluation of recharge and groundwater flow, taking into account the significant outcrop region in the study area. The geologic formations and structures were attributed to six corresponding zones of recharge that compose the semi-confined and free aquifer. The model was calibrated by the baseflow from daily hydrograms and by the static level from wells. It was carried out a sensitivity analysis including the calibration parameter set. The results show that there is interaction between aquifer recharge from the two basins and that the aquifer mainly drain its recharge into the rivers. The lateral flows (groundwater flows between basins), the deep discharge and the groundwater exploitation from wells represent small exits in comparison to the total recharge; however, the action of the wells presents effect with some regional trend in the vicinity of the biggest urban centers of the study area. The determination of the baseflows identified the stretches to long of the rivers in which the aquifer loads and is loaded. Despite the aquifer essentially supplying the rivers, the stretches in which the rivers load it are significant and important for being stretches in which the aquifer is potentially more vulnerable.

Keywords: Guarani Aquifer; aquifer recharge; model of flow 


\section{LISTA DE FIGURAS}

Figura 1 - Mapa simplificado da América do Sul com a localização do Sistema Aqüifero Guarani, fonte: ARAÚJO et al., 1999

Figura 2 - Estratigrafia e sistema de fluxo previsto entre seções geológicas típicas do Sistema Aqüífero Guarani, na região de Ribeirão Preto - SP (adaptado de SMA, 2004)

Figura 3 - Sistema de fluxo e potenciometria do SAG, obtidas a partir da informação de diversos poços (adaptado de ARAÚJO et al, 1999)

Figura 4 - Mecanismos de infiltração (LERNER, 1990)

Figura 5 - Mecanismos de infiltração, característicos da área de estudo 29

Figura 6 - Limites de sensibilidade dos métodos às estimativas de recarga, em relação ao tempo, espaço e fluxo, segundo SCANLON et al. (2002)

Figura 7 - Esquema conceitual de fluxos entre a superfície e o aqüífero, no qual: P- precipitação, ET - evapotranspiração, ES - escoamento superficial, $\mathrm{Rt}$ - recarga em trânsito e $\mathrm{R}$ - recarga do aqüífero

Figura 8 - Faixas de valor de condutividade hidráulica $K(\mathrm{~m} / \mathrm{dia})$ para diversos materiais (adaptado de HEATH, 1983)

Figura 9 - Condições de contorno no aqüífero, adaptado de ANDERSON e WOESSNER (1992)

Figura 10 - Fronteira não alinhada ao sistema de coordenadas, adaptado de FORTUNA (2000)

Figura 11 - Exemplos de malhas bi-dimensionais: (a) estruturada e (b) nãoestruturada

Figura 12 - Localização do sistema Jacaré formado pelas bacias contíguas do Jacaré-Guaçu (mais ao norte) e do Jacaré-Pepira (mais ao sul), em relação ao Estado de São Paulo

Figura 13 - Mapa geológico da área de estudo (fontes: mapas digitalizados IPT 2003; CORRÊA, 1995)

Figura 14 - Seções de derrames basálticos da Formação Serra Geral (GIAMPÁ e SOUZA, 1982) 
Figura 15 - Contornos das bacias do sistema Jacaré na região dos exutórios

Figura 16 - Isoietas médias anuais na UGRHI -TJ; distribuição de postos pluviométricos utilizados e contorno de sub-bacias (IPT, 2003)

Figura 17 - Localização de estações fluviométricas (E1 a E12) em relação à drenagem e formações geológicas

Figura 18 - Distribuição de poços cadastrados do Aqüífero Guarani, em regiões de aqüífero livre e confinado, nas bacias do JacaréGuaçu e Jacaré-Pepira

Figura 19 - Distribuição de poços cadastrados do Aqüifero Guarani, em regiões de aqüífero livre e confinado, nas bacias do JacaréGuaçu, Jacaré-Pepira e entorno

Figura 20 - Estratigrafia característica da região de São Carlos (FREITAS, 1996)

Figura 21 - Poço do SAAE em Ibitinga, com dispositivo para monitoramento do nível d'água; cota topográfica 512 m e NE 426 m, em 1995, fonte DAEE (1995)

Figura 22 - Poço desativado na cidade de Araraquara com difícil acesso a medição do nível d'água; rebaixamento de 38 m do NE (1978 2005)

Figura 23 - Poço do SAAE em Itirapina; rebaixamento de 4,5 m do NE (1999 - 2005)

Figura 24 - Poço do SAAE em Cambaratiba, distrito de Ibitinga; cota topográfica 450 m e NE 424 m, em 2005.

Figura 25 - Início do Rio Jacaré-Guaçu, no encontro dos ribeirões do Lobo e do Feijão, em região de Formação Serra Geral.

Figura 26 - Tributários do Rio Jacaré-Guaçu em região de Formação Serra Geral: (a) Ribeirão Bonito, distante 7 km do Rio Jacaré-Guaçu; (b) queda d'água no Ribeirão do Lobo, distante $5 \mathrm{~km}$ do Rio Jacaré-Guaçu.

Figura 27 - Rio Jacaré-Pepira, na cidade de Brotas, em região de Formação Serra Geral

Figura 28 - Mecanismos de recarga do modelo conceitual 
Figura 29 - Mecanismos de recarga no Aqüífero Guarani, proveniente de sistemas aqüíferos. 1. Percolação do aqüífero de formações do Grupo Bauru e equivalentes; 2. Escoamento externo ao aqüífero Bauru-basaltos; 3. Recarga interna por infiltração proveniente do aqüífero Bauru-basaltos; 4. Recarga externa por infiltração proveniente do aqüífero Bauru-basaltos; 5 . Recarga direta

Figura 30 - Estações fluviométricas nos rios principais (E1 a E8) e nos rios das bacias-referência (E9 a E12), utilizadas na estimativa de fluxo de base do Aqüífero Guarani

Figura 31 - Modelo digital de superfície das Bacias do Jacaré-Guaçu e Jacaré-Pepira

Figura 32 - Cotas de base e topo (em m.s.n.m) e espessura do Aqüífero

Guarani (em m), respectivamente (a), (b) e (c)

Figura 33 - Níveis piezométricos atribuídos à área das bacias e do seu entorno

Figura 34 - Distribuição dos erros atribuídos à estimativa dos níveis piezométricos

Figura 35 - Seções hidrogeológicas

Figura 36 - Perfis hidrogeológicos com os valores de cotas de base e topo do Aqüífero Guarani e nível potenciométrico. (a) seção longitudinal (A-B), sentido NW-SE, (b) seção transversal (C-D), sentido N-S.

Figura 37 - Trechos de interação rio-aqüífero

Figura 38 - Detalhe de poços e rio com configuração de malha mista

Figura 39 - Trecho da malha apresentando complexidade devido à elevada concentração de poços e contornos na região de São Carlos.

Figura 40 - Detalhe de zonas de recarga, na região de Araraquara, atribuídas à malha, como exemplo de dados tipo estrutura.

Figura 41 - Zonas de recarga atribuídas por formações

Figura 42 - Trechos da malha com atribuição de condição de contorno de $2^{\circ}$ tipo

Figura 43 - Seqüência de ajustes de parâmetros utilizados na calibração 
Figura 44 - Dados calculados versus observados (ou estimados) para o modelo calibrado: dados de carga hidráulica $(h)$ e vazão $\left(Q_{b}\right)$, figuras (a) e (b), respectivamente

Figura 45 - Isolinhas de carga hidráulica estimada e calculada

Figura 46 - Vazões de base estimada e calculada para o Aqüífero Guarani, referentes às estações fluviométricas ao longo dos rios JacaréGuaçu (E1 a E6) (a) e Jacaré-Pepira (E7 e E8) (b)

Figura 47 - Escoamentos de base decorrentes da especificação de cargas hidráulicas

Figura 48 - Interacao rio-aqüífero (trechos de recarga e descarga), em relação às formações geológicas mostradas em seções, em plano (lado esquerdo) e em corte (lado direito)

Figura 49 - Distribuição da condutividade hidráulica na área de estudo

Figura 50 - Influência dos parâmetros de ajuste de calibração (PACs) em relação aos valores de RMSEH (a) e RMSEQ (b).

Figura 51 - Localização da área complementar de drenagem, em relação à área de drenagem correspondente às estações fluviométricas E1 e E7

Figura 52 - Efeito dos poços sobre os níveis estáticos - rebaixamento da carga hidráulica

Figura 53 - Superfície piezométrica do Aqüífero Guarani (cotas em m.s.n.m) e o efeito local de poços sobre o rebaixamento dos níveis estáticos (NE)

Figura 54 - Distribuição da transmissividade na área de estudo 145

Figura 55 - Hidrograma da estação E1 - Rio Jacaré-Guaçu

Figura 56 - Hidrograma da estação E2 - Rio Jacaré-Guaçu 162

Figura 57 - Hidrograma da estação E3 - Rio Jacaré-Guaçu 163

Figura 58 - Hidrograma da estação E4 - Rio Jacaré-Guaçu 164

Figura 59 - Hidrograma da estação E5 - Rio Jacaré-Guaçu 165

Figura 60 - Hidrograma da estação E6 - Rio Jacaré-Guaçu 166

Figura 61 - Hidrograma da estação E7 - Rio Jacaré-Pepira 167

Figura 62 - Hidrograma da estação E8 - Rio Jacaré-Pepira 168

Figura 63 - Hidrograma da estação E9 - Rio São João, tributário do Jacaré-Guaçu 
Figura 64 - Hidrograma da estação E10 - Ribeirão Pinheiros, tributário do Jacaré-Pepira

Figura 65 - Hidrograma da estação E11 - Ribeirão da Onça, tributário do Jacaré-Guaçu

Figura 66 - Hidrograma da estação E12 - Córrego do Gregório, tributário do Jacaré-Guaçu 


\section{LISTA DE TABELAS}

Tabela 1 - Estratigrafia e hidroestratigrafia do SAG (ARAÚJO et al., 1999) 22

Tabela 2 - Propriedades geométricas e hidráulicas das Fms. Botucatu e Pirambóia (ARAÚJO et al., 1999) 22

Tabela 3 - Síntese das avaliações de reservas do SAG 26

Tabela 4 - Adequação de métodos de estimativa de recarga (KINZELBACH et al., 2002; SCANLON et al., 2002)

32

Tabela 5 - Faixas de valor de armazenamento específico $S_{s}\left(m^{-1}\right)$ para diversos materiais (adaptado de DOMENICO, 1972)

Tabela 6 - Faixas de valor de rendimento específico $S_{y}$ para diversos materiais (adaptado de MORRIS e JOHNSON, 1967)

Tabela 7 - Coluna litoestratigráfica de parte da Bacia do Paraná (IPT, 1981; IPT, 2003)

Tabela 8 - Precipitação média anual histórica nas sub-bacias do sistema Jacaré, segundo divisão das sub-bacias em IPT (2003).

Tabela 9 - Volumes anuais em estações fluviométricas ao longo dos rios Jacaré-Guaçu, Jacaré-Pepira e tributários (fonte: DAEE/CTH, ANA, 2004)

Tabela 10 - Características hidrodinâmicas do Aqüífero Guarani na área de estudo, segundo DAEE (1974)

Tabela 11 - Características hidrodinâmicas do Aqüífero Guarani, segundo CORRÊA (1995).

Tabela 12 - Características hidrodinâmicas do Aqüífero Guarani, segundo IPT (2003)

Tabela 13 - Característica dos dados utilizados no modelo numérico

Tabela 14 - Vazões estimadas ao longo dos rios, Jacaré-Guaçu (estações

E1 a E6) e Jacaré-Pepira (estações E7 e E8)

Tabela 15 - Valores anuais de recarga do Aqüífero Guarani, distribuídos por formações e estruturas geológicas

Tabela 16 -Balanço hídrico com valores anuais obtidos para o Aqüífero Guarani para a área total de estudo 


\section{SUMÁRIO}

RESUMO V V

ABSTRACT

1 INTRODUÇÃO 16

2 REVISÃO BIBLIOGRÁFICA 18

2.1 SISTEMA AQÜÍFERO GUARANI 18

2.1.1 Características geológicas 19

2.1.2 Hidrogeologia 21

2.1.3 Clima e hidrologia 25

2.1.4 Disponibilidade hídrica 25

2.2 RECARGA DE AQÜÍFEROS 27

2.2.1 Processos de recarga - paralelos com a área de estudo 28

2.2.2 Métodos de quantificação de recarga 32

2.2.2.1 Métodos de traçadores 36

2.2.2.2 Métodos físicos 39

2.2.2.3 Métodos de modelo computacional 42

2.3 INCERTEZA NOS MODELOS DE ÁGUA SUBTERRÂNEA 43

2.3.1 Fontes de incerteza associadas a informações prévias $\quad 44$

2.3.1.1 Cargas hidráulicas 45

2.3.1.2 Fluxos 47

2.3.1.3 Parâmetros hidráulicos 49

2.3.2 Erros na definição do modelo conceitual 53

2.3.3 Erros no desenvolvimento do modelo numérico 54

2.3.3.1 Erros de modelagem 56

2.3.3.1.1 Características e incertezas na aplicações das condições de contorno $\quad 59$

2.3.3.1.2 Aplicação de condições iniciais 60

2.3.3.2 Erros de discretização geométrica e temporal 61

2.3.3.3 Erros na solução numérica 64

2.3.4 Aplicação de elementos de modelagem - aspectos de incerteza 65

2.4 CONTRIBUIÇÃO DA REVISÃo AO MODELO PROPOSTO 68 
3 ÁREA DE ESTUDO 69

$\begin{array}{lll}3.1 & \text { GEOLOGIA } & \mathbf{7 0}\end{array}$

3.2 HIDROLOGIA 75

$\begin{array}{lll}3.2 .1 & \text { Precipitação } & 77\end{array}$

3.2.2 Drenagem e Fluviometria 79

$\begin{array}{llcc}3.2 .3 & \text { Poços } & 83\end{array}$

$\begin{array}{lll}3.2 .4 & \text { Evapotranspiração } & 85\end{array}$

3.3 HIDROGEOLOGIA 86

3.3.1 Características regionais 86

3.3.2 Características dimensionais $\quad 87$

3.3.3 Características das camadas confinantes e semiconfinates $\quad 88$

3.3.4 Recarga e fluxo natural 90

3.3.5 Características Hidrodinâmicas 91

3.4 DADOS DE CAMPO 92

4 METODOLOGIA 100

$\begin{array}{lll}4.1 & \text { MODELO CONCEITUAL } & 100\end{array}$

4.2 OBTENÇÃO E PROCESSAMENTO DE DADOS EM SIG 105

$\begin{array}{lll}\text { 4.2.1 Dados armazenados } & 106\end{array}$

$\begin{array}{lll}\text { 4.2.2 Dados processados } & 107\end{array}$

4.2.2.1 Fisiografia da bacia e domínio do aqüífero 107

4.2.2.2 Superfície potenciométrica 111

4.2.2.3 Perfis Hidrogeológicos 113

$\begin{array}{ll}\text { 4.2.2.4 Interação rio-aqüífero } & 116\end{array}$

4.3 MODELO NUMÉRICO 117

$\begin{array}{ll}\text { 4.3.1 Aquisição de dados } & 118\end{array}$

$\begin{array}{ll}\text { 4.3.2 Geração de malha } & 119\end{array}$

4.3.3 Recarga e condições de contorno 122

$\begin{array}{ll}\text { 4.3.4 Calibração do modelo } & 124\end{array}$

$\begin{array}{lll}\text { 4.3.5 Análise de sensibilidade } & 134\end{array}$

5 RESULTADOS E DISCUSSÃO 137

6 CONCLUSÕES 147

7 REFERÊNCIAS 149

APÊNDICE A - Hidrogramas $\quad 160$ 
APÊNDICE B - Programas - Interpolacão de cargas hidráulicas e exportação de dados em formato SPA

ANEXO A - Poços - dados para calibração

ANEXO B - Poços - dados de explotação 


\section{INTRODUÇÃO}

Este trabalho visa estimar a recarga e o sistema de fluxo do Aqüífero Guarani por meio de um modelo numérico, estabelecido por um modelo conceitual de escoamento subterrâneo, na área delimitada pelas bacias hidrográficas contíguas dos rios Jacaré-Guaçu e Jacaré-Pepira (sub-bacias do Rio Tietê, na região central do Estado de São Paulo), denominadas de sistema Jacaré. Esta área, de $6.748 \mathrm{~km}^{2}$, possui $46 \%$ de afloramento do Aqüífero Guarani (2,6\% de toda a área de afloramento do Aqüífero). Para isso, foram utilizados recursos de sistema de informações geográficas (SIG) (Arcview, ESRI, 2002), como forma de georeferenciar, armazenar, visualizar e gerar dados, bem como, fornecê-los em formato específico para elaboração do modelo numérico.

Para implementação do trabalho visando os propósitos acima, foi feita uma revisão dos trabalhos mais significativos sobre a região das bacias e similares, abrangendo dados provenientes de fontes governamentais e acadêmicas, sobre a geologia de superfície e de subsuperfície, envolvendo o Guarani livre e confinado, ou semiconfinado. Foram também compilados dados sobre a fisiografia, hidrografia, distribuição de poços de captação de água, precipitação e drenagem dos rios principais, sendo estes dados classificados e apresentados como características geológicas, hidrológicas e hidrogeológicas da área de estudo. Os dados da fisiografia e geometria subterrânea, digitalizados pontualmente, foram generalizados para toda a área das bacias através de interpolação por krigagem. Sobre os dados de geometria subterrânea, foi adicionalmente utilizada técnica de operação de rasters para generalizar a distribuição dos dados de espessura e confinamento do Aqüífero.

Adicionalmente ao estudo específico sobre a área de estudo e seu entorno, foi realizado um estudo mais geral sobre as características do Aqüífero Guarani, envolvendo, sobretudo, sua geologia e hidrogeologia como forma de estabelecer parâmetros iniciais, posteriormente detalhados para a área de estudo. Uma 
revisão sobre tipos e processos de recarga foi feita, visando estabelecer paralelos com o sistema de recarga e sua implementação no modelo conceitual adotado. Como forma de auxiliar a construção dos modelos conceitual e numérico, no que diz respeito às decisões relacionadas a fontes de erro, foi feita uma revisão sobre incertezas na construção de modelos aplicados a aqüiferos.

A partir da análise dos dados georeferenciados pelo SIG, foi proposto inicialmente um modelo conceitual, e posteriormente ajustado, após obtenção dos primeiros resultados do modelo numérico. Este último teve início com a geração da malha, definida pelo contorno das bacias, drenagem e poços, e posteriormente atribuído os demais dados como estruturas, seguido da implementação numérica e de sua calibração e análise de sensibilidade.

A área de estudo formada pelas duas bacias foi escolhida principalmente pelo fato do Aqǘfero Guarani - reconhecidamente um dos maiores mananciais subterrâneos transfronteiriços do mundo (aproximadamente $1.200 .000 \mathrm{~km}^{2}$ ), caracterizado como aqǘfero confinado - apresentar-se aflorante em parte significativa da área de estudo; por apresentar fortes indícios de conexão hidráulica entre as duas bacias (CORRÊA, 1995); por possuir uma estratigrafia de confinamento e semiconfinamento típica do Sistema Aqüifero Guarani (SAG) e por incluir áreas com grande diversidade de atividades urbana, agrícola e industrial. Segundo a OAS/GEF (2001), o conhecimento do comportamento do Aqüifero Guarani, sobretudo nas áreas sujeitas à recarga direta, naturalmente mais vulneráveis, tem uma importância maior para sua conservação e fornecimento de subsídios aos intentos de proteção ambiental e desenvolvimento sustentável, que visem assegurar a qualidade e a quantidade de seu manancial às futuras gerações. 


\section{REVISÃO BIBLIOGRÁFICA}

Este capítulo é dividido em três partes: na primeira, são apresentadas as características do SAG, na segunda, são identificados e analisados as formas e métodos de estimativa de recarga, e na terceira, são identificadas as fontes de incerteza relacionadas à elaboração de modelos. Este estudo preliminar visou dar subsídios à elaboração dos modelos conceitual e numérico, ainda que elementos aqui apresentados e comparados não tenham sido empregados neste trabalho.

\subsection{SISTEMA AQÜÍFERO GUARANI}

Nesta seção é apresentada uma visão geral das características mais relevantes do SAG, permitindo-se comparar posteriormente suas semelhanças, diferenças e peculiaridades, com a área de estudo, bem como, comparar aspectos comuns, porém, que incidem com valores médios diferentes, como a espessura do aqüífero, parâmetros hidráulicos e sistema de fluxo.

Segundo o relatório da UNESCO/PHI (2003), existem no mundo 261 bacias hidrográficas transfronteiriças compartilhadas por 145 paises, sendo aproximadamente um terço dessas bacias pertencentes a mais de dois paises. $O$ Aqüífero Guarani, localizado no centro-sul da América do Sul, abrange partes da Argentina, Brasil, Paraguai e Uruguai. Neste que é o continente mais rico do planeta em recursos hídricos, o Aqüífero chama atenção por sua extensão e volume armazenado de água, sendo considerado um dos maiores mananciais de água doce subterrânea transfronteiriço do mundo. Estendendo-se desde a Bacia Sedimentar do Paraná até a Bacia do Chaco Paraná, perfaz uma área de aproximadamente 1,2 milhão de $\mathrm{km}^{2}$, sendo um aqüífero caracteristicamente confinado por um dos maiores derrames de rochas vulcânicas do mundo, possui 
aproximadamente $10 \%$ de sua área livre de confinamento. O conjunto formado pelas rochas sedimentares de arenitos e o confinamento basáltico é o que se denomina Sistema Aqüifero Guarani (SAG). De sua extensão total, $225.500 \mathrm{~km}^{2}$ cabem à Argentina, $839.800 \mathrm{~km}^{2}$ ao Brasil, $71.700 \mathrm{~km}^{2}$ ao Paraguai e $58.500 \mathrm{~km}^{2}$ ao Uruguai (Figura 1).

O Aqüífero configura-se como um manancial estratégico, devido a sua característica hidrogeológica, extensão e localização - pertencente ou próxima a regiões de grande importância sócio-econômica para os quatro países.

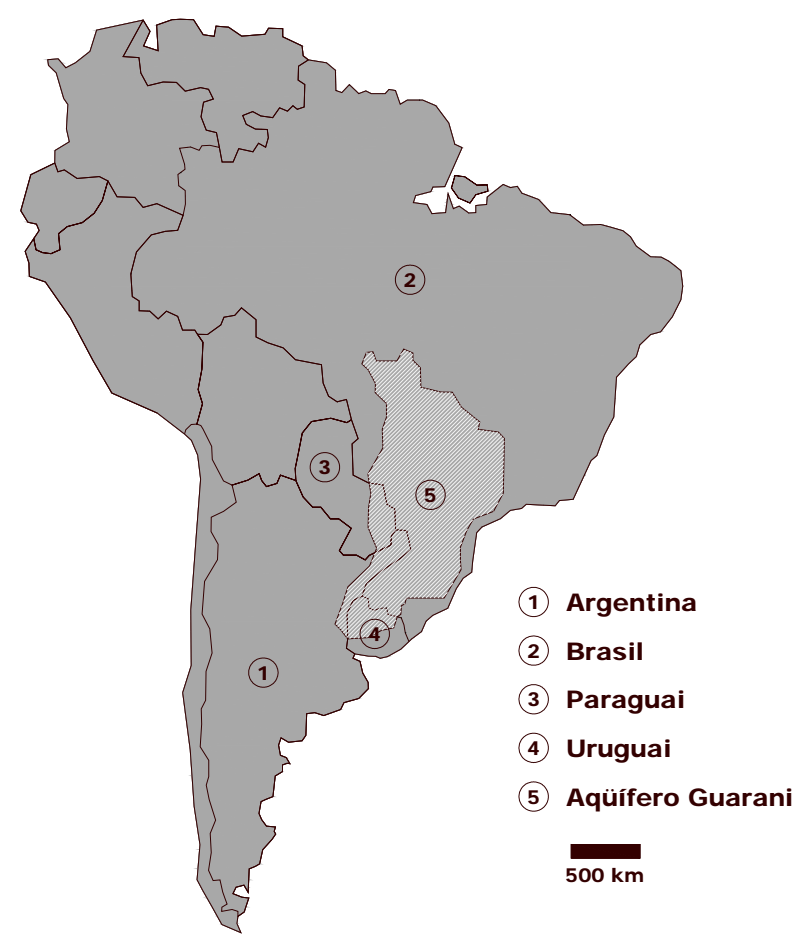

Figura 1 - Mapa simplificado da América do Sul com a localização do Sistema Aqüifero Guarani, fonte: ARAÚJO et al., 1999

\subsubsection{Características geológicas}

A litoestratigrafia do SAG é formada por uma distribuição de rochas que dão ao sistema sua maior identidade. Ela inclui rochas dos períodos Triássico, Jurássico e Cretáceo, estratificada, de modo geral, numa seqüência que inclui o Aqüífero Guarani, uma estrutura subjacente e outra sobrejacente. O Aqüífero Guarani é composto por arenitos que compreendem duas formações, dos 
períodos Triássico e Jurássico, no Brasil, respectivamente, as formações Pirambóia e Botucatu. Os arenitos do período Jurássico, de origem eólica e maior capacidade hídrica, constituem-se nos melhores reservatórios subterrâneos, enquanto os do Triássico, de origem flúvio-lacustre/eólico possuem elevado nível de argila, que compromete sua eficiência hidráulica. A estrutura subjacente ao Aqüífero compreende uma formação de baixa permeabilidade e caracteriza-se como um aquitardo (Permo-Triássico). Acima, o Aqüífero Guarani é recoberto por sucessivas camadas de derrame basáltico, provenientes de atividade vulcânica, que formam rochas consolidadas, descontínuas, caracterizadas em parte como aquitardo e em parte como um aqüífero (do período Cretáceo, no Brasil, denominadas como Formação Serra Geral). Por sua vez, estas são recobertas, em partes da Bacia do Paraná, por arenitos caracterizados como um aqüífero superior da seqüência (período Cretáceo, no Brasil, denominados como formações do Grupo Bauru). A Formação Botucatu compõe o principal sistema aqüífero do Aqüífero Guarani (ROCHA, 1997).

O Aqüífero Guarani tem uma espessura média de 250 metros, variando de poucos metros (nas bordas da bacia) a aproximadamente $800 \mathrm{~m}$ (em sua parte central), como nas partes norte dos Estados de São Paulo, Paraná e ao sul do Estado de Mato Grosso do Sul. A profundidade de seu topo, em relação ao nível do solo, varia de zero (região de afloramento) até $1.000 \mathrm{~m}$ na Argentina. A Formação Serra Geral tem como principais condicionantes estruturais soerguimentos com formação de arcos e sistemas de falhas (ARAÚJO et al., 1999)

A Figura 2 mostra uma seção geológica típica do conjunto desta estratificação geológica. 


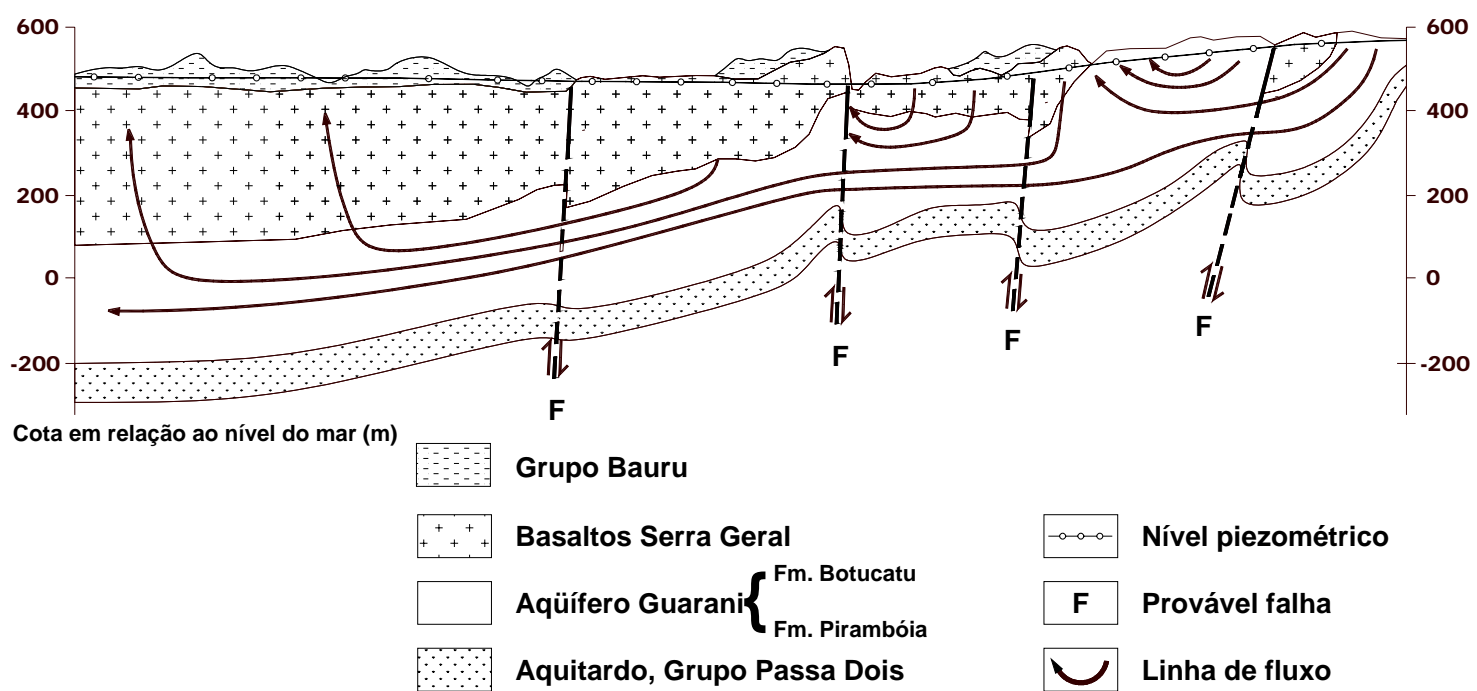

Figura 2 - Estratigrafia e sistema de fluxo previsto entre seções geológicas típicas do Sistema Aqüífero Guarani, na região de Ribeirão Preto - SP (adaptado de SMA, 2004)

\subsubsection{Hidrogeologia}

Para simplificação da descrição das características hidrogeológicas das estruturas que compõem o SAG, é adotado como exemplo a nomenclatura das formações denominadas no Brasil, podendo, em geral, ser atribuídas as mesmas características às formações correspondentes nos demais países, como mostra a Tabela 1.

De um modo geral, o Aqüífero Guarani é caracterizado por uma unidade confinada de arenitos com valores elevados de condutividade hidráulica, $K$, que diminui com a profundidade devido ao aumento da proporção de argilas (CAMPOS, 1999).

Valores médios sobre a geometria e parâmetros hidráulicos são apresentados por ARAÚJO et al., 1999 (Tabela 2) e em BORGHETTI et al. (2004) são referenciados valores, válidos para o Aqüífero Guarani, de condutividade hidráulica, $K$, entre 0,2 e 4,6 m/dia (média de $3 \mathrm{~m} / \mathrm{d}$ ) e valores mais comuns de transmissividade, $T$, entre 150 e $800 \mathrm{~m}^{2} /$ dia. 
Tabela 1 - Estratigrafia e hidroestratigrafia do SAG e do seu entorno (ARAÚJO et al., 1999)

\begin{tabular}{|c|c|c|c|c|c|}
\hline $\begin{array}{c}\text { Unidade } \\
\text { Hidroestratigráfica }\end{array}$ & Período & Brasil & Argentina & Paraguai & Uruguai \\
\hline Aqüífero superior & Cretáceo & Grupo Bauru & $\begin{array}{l}\text { Fm. Quebrada } \\
\text { Monardes }\end{array}$ & Fm. Acaray & Fm. Ascencio \\
\hline $\begin{array}{l}\text { Aquitardo / aqúífero } \\
\text { (confinante de topo) }\end{array}$ & Cretáceo & Fm. Serra Geral & Fm. Serra Geral & $\begin{array}{l}\text { Fm. Alto } \\
\text { Paraná }\end{array}$ & Fm. Arapey \\
\hline \multirow[t]{2}{*}{ Aqüífero Guarani } & & & Fm. Taquarembó & Fm. Missiones & $\begin{array}{l}\text { Fm. } \\
\text { Tacuarembó }\end{array}$ \\
\hline & Triássico & $\begin{array}{l}\text { Fms. Pirambóia / } \\
\text { Rosário do Sul }\end{array}$ & Fm. Buena Vista & Fm. Missiones & Fm. Buena Vista \\
\hline $\begin{array}{l}\text { Aquitardo } \\
\text { (confinante de base) }\end{array}$ & $\begin{array}{l}\text { Permo- } \\
\text { Triássico }\end{array}$ & Fm. Rio do Rasto & $\begin{array}{l}\text { Fm.Victorino } \\
\text { Rodrigues }\end{array}$ & $\begin{array}{l}\text { sem } \\
\text { denominação }\end{array}$ & Fm.Yaguary \\
\hline
\end{tabular}

Tabela 2 - Propriedades geométricas e hidráulicas das Fms. Botucatu e Pirambóia (ARAÚJO et al., 1999)

\begin{tabular}{l|c|c}
\hline Parâmetro & Formação Botucatu & Formação Pirambóia \\
\hline \hline Variação da espessura & $4-484(\mathrm{~m})$ & $25-770(\mathrm{~m})$ \\
Espessura média & $138(\mathrm{~m})$ & $139(\mathrm{~m})$ \\
Variação da porosidade & $17-30(\%)$ & $14-24(\%)$ \\
Condutividade hidráulica média $(K)$ & $8,7(\mathrm{~m} / \mathrm{d})$ & $1,9(\mathrm{~m} / \mathrm{d})$ \\
Variação da transmissividade $(T)$ & $2,4-552\left(\mathrm{~m}^{2} / \mathrm{d}\right)$ & não confiáveis \\
\hline
\end{tabular}

A provável recarga do Aqüífero Guarani dá-se segundo dois mecanismos principais: por infiltração direta, através de sua zona de afloramento nos estados brasileiros (São Paulo, Goiás, Mato Grosso do Sul, Paraná e Santa Catarina), leste do Paraguai e norte do Uruguai e, indiretamente, através das formações sobrepostas que incluem o sistema de fraturas da Formação Serra Geral (Figura 2 e Figura 3). De fato, a zona aqüífera de basaltos nada mais é do que o prolongamento do aqüífero sedimentar sobrejacente (formações do Grupo Bauru). Este fato tem grande interesse prático porque onde a capa sedimentar é pouco espessa ou descontínua, não oferecendo condições de captação, constitui um meio aqüífero de transferência de água para o sistema aqüífero fraturado. Tendo em vista essa característica, segundo ROSA FILHO et al. (2003), o aqüífero fraturado nos basaltos pode ser considerado como componente do mesmo sistema hidrogeológico, ainda que, parcialmente. Localmente, onde as espessuras do basalto se tornam pequenas, ou os fendilhamentos atinjam o topo 
deste sistema aqüífero, desde que os níveis potenciométricos do basalto sejam superiores àqueles do Aqüífero Guarani confinado, é possível a infiltração vertical descendente. Inversamente, onde os níveis potenciométricos do Aqüífero Guarani (Figura 2) sobrepujam os do sistema aqüífero sobrejacente, verifica-se fluxos ascendentes. Tendo em vista a localização da superfície potenciométrica em muitos lugares se apresentar acima do topo dos reservatórios sedimentares do Aqüífero Guarani, as rochas basálticas da Formação Serra geral funcionam também como reservatório, além de seu caráter de barreira hidráulica.

Essas características, ao mesmo tempo em que conferem uma maior potencialidade ao sistema hídrico do SAG, estabelecem uma maior complexidade em seu sistema de fluxos e uma via de contaminação através da Formação Serra Geral, proveniente de atividades industriais, agrícolas e domésticas desenvolvidas ao longo da região que compõe o Grupo Bauru, bem como, das formações correspondentes, nos demais países que compõem o SAG.

Três arcos estruturais principais (Arco Assunção, Arco Ponta Grossa e Arco Rio Grande), que constituem soerguimentos basais, juntamente com a localização das zonas de recarga, inclinação preferencial do Aqüífero Guarani e as variações de sua espessura, condicionam o sistema principal de fluxo no SAG. Os níveis de carga hidráulica, obtidos a partir da investigação de diversos poços (Figura 3), confirmam o fluxo principal. O fluxo é preferencialmente direcionado ao Rio Paraná, que percorre a Bacia de NE-SW e configura o principal destino da descarga de base do SAG, enquanto que a principal área de descarga subterrânea localiza-se entre os rios Paraná e Uruguai, na Argentina, a oeste do Arco Rio Grande (ARAÚJO et al., 1999). 


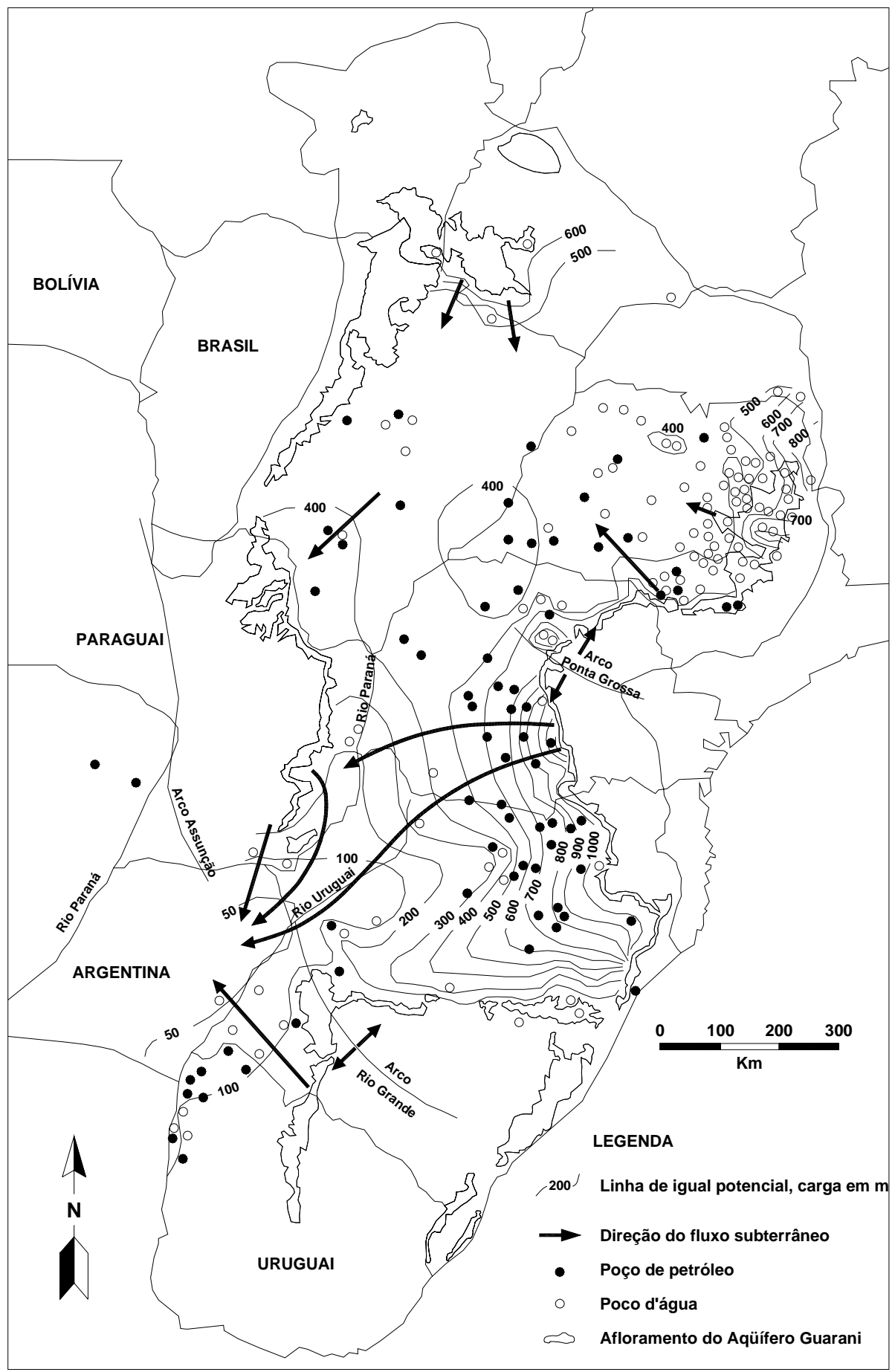

Figura 3 - Sistema de fluxo e potenciometria do SAG, obtidas a partir da informação de diversos poços (adaptado de ARAÚJO et al., 1999) 


\subsubsection{Clima e hidrologia}

Uma grande variação das características climáticas é observada nas bacias que abrangem o Aqüífero, devido ao seu longo comprimento, o qual, se estende por $20^{\circ}$ de latitude ou aproximadamente $2.200 \mathrm{~km}$. O clima da região varia de subtropical, em sua região norte, a temperado e quase semi-árido em sua parte mais ao sul. As temperaturas médias variam de $11^{\circ}$ a $29^{\circ} \mathrm{C}$ e as precipitações anuais variam de 1.000 a $1.800 \mathrm{~mm}$, respectivamente correspondente às regiões SW e NE (DNM, 1992). A evapotranspiração, fortemente associada à incidência de chuvas, no Brasil, aponta para valores anuais da ordem de $980 \mathrm{~mm}$ em regiões com precipitação em torno de $1.400 \mathrm{~mm}$ (BRAGA et al., 1991).

Além dos aspectos climáticos, a geometria, parâmetros hidráulicos e condições de recarga e descarga do aqüífero determinam a quantidade de água subterrânea que flui através deste. Estima-se para as regiões de afloramento do Aqüífero Guarani que 15\% (REBOUÇAS, 1976) a 19\% (ANA, 2005) da precipitação infiltram diretamente no mesmo e são restituídos aos rios, enquanto que as infiltrações indiretas, ao longo do aqüífero confinado, são de mais difícil quantificação.

\subsubsection{Disponibilidade hídrica}

O conhecimento sobre a disponibilidade hídrica é essencial às pretensões de gestão dos aqüíferos, sendo composta pelas estimativas das reservas ativas ou reguladoras e reservas permanentes. As reservas reguladoras, que correspondem à porção do manancial sujeita a flutuações sazonais do nível da água, são comumente estabelecidas pela relação entre escoamento de base e precipitação, enquanto as reservas permanentes, que correspondem ao volume de água do aqüífero situado abaixo da zona de flutuação sazonal, são estabelecidas pelos parâmetros de armazenamento e dimensões do aqüífero. Complementarmente, a reserva explotável é uma estimativa freqüentemente desejada, estabelecida a partir da disponibilidade hídrica, atribuindo-se um 
percentual, em geral, sobre as reservas reguladoras. Sobre a disponibilidade hídrica do Aqüífero Guarani, as referências mais citadas são os trabalhos de REBOUÇAS (1976), ROCHA (1997) e CHANG (2001); os respectivos achados referentes às reservas encontram-se na Tabela 3.

Em REBOUÇAS (1976), a reserva permanente foi estimada para uma área total de $800.000 \mathrm{~km}^{2}$, espessura média de $300 \mathrm{~m}$ e coeficiente de armazenamento de $20 \%$, enquanto a reserva reguladora foi subdividida em infiltração direta e indireta. A infiltração direta considerou a recarga como sendo 15\% da precipitação média anual $(1.500 \mathrm{~mm})$, distribuída sobre uma área de $87.000 \mathrm{~km}^{2}$; já a infiltração indireta foi estimada considerando a condutividade hidráulica $\left(5.10^{-8}\right.$ $\mathrm{m} / \mathrm{s})$, diferença de potencial hidráulico médio $(100 \mathrm{~m})$ e espessura média da camada infiltrante $(400 \mathrm{~m})$.

Em ROCHA (1997) é apresentada uma avaliação para toda a área do SAG, incluindo Argentina, Brasil, Paraguai e Uruguai. Foram utilizados os parâmetros de espessura média $(250 \mathrm{~m})$; porosidade efetiva $(15 \%)$ e coeficiente de armazenamento $\left(10^{-4}\right)$. Foi considerado o índice de $25 \%$ para a reserva explotável, em relação à reserva reguladora, justificado pelo uso racional do manancial.

Em CHANG (2001) foi estimada a reserva reguladora proveniente da recarga direta, para uma área de afloramento de $89.936 \mathrm{~km}^{2}$. Foi considerado um valor médio da recarga (4\%) em relação à precipitação (considerada entre 1.300 e $1.500 \mathrm{~mm})$.

Apesar dos valores favoráveis de disponibilidade hídrica, sinais de superexplotação são observados localmente devido à má distribuição da demanda, decorrente do consumo elevado dos recursos hídricos em regiões de maior concentração populacional, p. ex., nas cidades de Ribeirão Preto e Bauru - SP (GEF, 2002).

Tabela 3 - Síntese das avaliações de reservas do SAG

\begin{tabular}{|c|c|c|c|}
\hline \multirow{2}{*}{ Reservas } & \multicolumn{3}{|c|}{ Fontes } \\
\hline & Rebouças (1976)* & Rocha $(1997)^{\star \star}$ & Chang $(2001)^{*}$ \\
\hline Ativa (infiltração direta) & $22 \mathrm{~km}^{3} / \mathrm{ano}$ & $160 \mathrm{~km}^{3} / \mathrm{ano}$ & $5,2 \mathrm{~km}^{3} / \mathrm{ano}$ \\
\hline Ativa (infiltração indireta) & $138 \mathrm{~km}^{3} / \mathrm{ano}$ & & \\
\hline Permanente & $48.021 \mathrm{~km}^{3}$ & $37.000 \mathrm{~km}^{3}$ & \\
\hline Explotável & & $40 \mathrm{~km}^{3} / \mathrm{ano}$ & \\
\hline
\end{tabular}

${ }^{*}$ ) Aplicável à região brasileira do SAG; $\left(^{* *}\right)$ Aplicável à região total do SAG 


\subsection{RECARGA DE AQÜÍFEROS}

Para o gerenciamento sustentável de recursos hídricos subterrâneos (abrangendo avaliações de quantidade e qualidade), a recarga de aqüífero é o elemento mais requerido. Entretanto, a recarga se configura, freqüentemente, na quantidade hidrogeológica menos conhecida, não podendo ser medida em escala espacial razoável. Em vão, grande esforço tem sido empregado para se estabelecer um único método de recarga seguro, devido à complexidade dos fenômenos e grande variedade de situações encontradas (KINZELBACH et al., 2002), ou, colocado de outro modo, a diversidade de métodos seja, provavelmente, imprescindível e reflita a grande variabilidade dos processos pelos quais se dá a recarga. Embora a variabilidade espacial (em escalas local e intermediária) possa não ser crítica para a avaliação de recursos hídricos, é crítica para o transporte de contaminantes, devido às recargas pontuais e aos fluxos preferenciais que podem permitir, rapidamente, a migração de contaminantes através da zona não saturada até o aqüifero (SCANLON et al., 2002). Contudo, este processo é atenuado nas regiões em que o Aqüifero Guarani se apresenta confinado, ficando sua vulnerabilidade dependente, sobretudo, das características da Formação Serra Geral.

A recarga é definida, de modo geral, como "a entrada de água, na zona saturada, disponível, tanto à superfície do nível freático como ao restante do fluxo da zona saturada" (FREEZE e CHERRY, 1979). Essa definição, portanto, não exclui as contribuições de fluxos laterais ao reservatório do aqüífero, contudo, mais comumente, a recarga é atribuída ao fluxo descendente que atinge o nível freático e/ou passa a compor o reservatório conformado pelo aqüífero. Os elementos naturais que influenciam a recarga podem ser agrupados pela relação que os mesmos possuem com a hidrometeorologia, a geomorfologia e a geologia, como descrito a seguir:

a) a hidrometeorologia, abrangendo elementos da hidrologia e do clima (precipitação, evapotranspiração, drenagem e temperatura), desempenha um papel destacado, por caracterizar as regiões com diferentes graus de umidade que, alteram essencialmente a recarga, devido, p.ex., à profundidade do nível freático (espessura da zona vadosa), à variação temporal do nível 
potenciométrico, à periodicidade e quantidade de infiltração, ao regime de vazão da drenagem entre outros (WINTER, 2001; SANFORD, 2002);

b) a geomorfologia, abrangendo elementos de topografia, solo e vegetação, altera a quantidade e distribuição da infiltração, devido às diferentes situações de: inclinação dos terrenos, interação da zona radicular com o solo e necessidade hídrica das cultura (SALAMA, 1994; ALLISON et al., 1990);

c) a geologia, abrangendo a distribuição espacial e litoestratigrafia das formações, interfere na quantidade e distribuição da infiltração e percolação da água, devido às correspondentes características hidráulicas (que podem variar de diversas ordens de grandeza) dos sistemas aqüíferos, formados pelas respectivas rochas (COOK, et al., 1992; LERNER, 1990; REBOUÇAS, 1976).

A atividade antrópica é, em alguns casos, também elemento a interferir na recarga. Essa interferência se dá, essencialmente, através de alteração das condições de permeabilidade do solo e da redistribuição espacial de recarga (decorrentes de construções e atividades em áreas urbanas), uso de irrigação (mananciais subterrâneo ou de superfície), desmatamento ou troca de cobertura nativa por vegetação de necessidade hídrica naturalmente incomum (ALLISON et al., 1990; LEDUC, et al., 2001). Todas essas atividades alteram a recarga, inclusive, por, na maioria das vezes, modificarem a interação entre os recursos hídricos subterrâneos e de superfície.

\subsubsection{Processos de recarga - paralelos com a área de estudo}

As diversas etapas no processo de recarga de aqüífero, ainda que possuam dificuldades de quantificação e monitoramento, são, como idéia geral, bem conhecidas. Em LERNER et al. (1990), os principais mecanismos de recarga foram conceitualmente definidos e as respectivas terminologias, apresentadas (Figura 4). No referido trabalho, a recarga direta corresponde à água, incorporada ao aqüífero, que excede o déficit de umidade e evapotranspiração (ET) do solo; a recarga indireta corresponde à água que percola através do leito de mananciais de superfície, até o nível freático, enquanto a recarga localizada é formada pela 
água acumulada próximo ao solo, em superfícies planas e desprovidas de canais definidos.

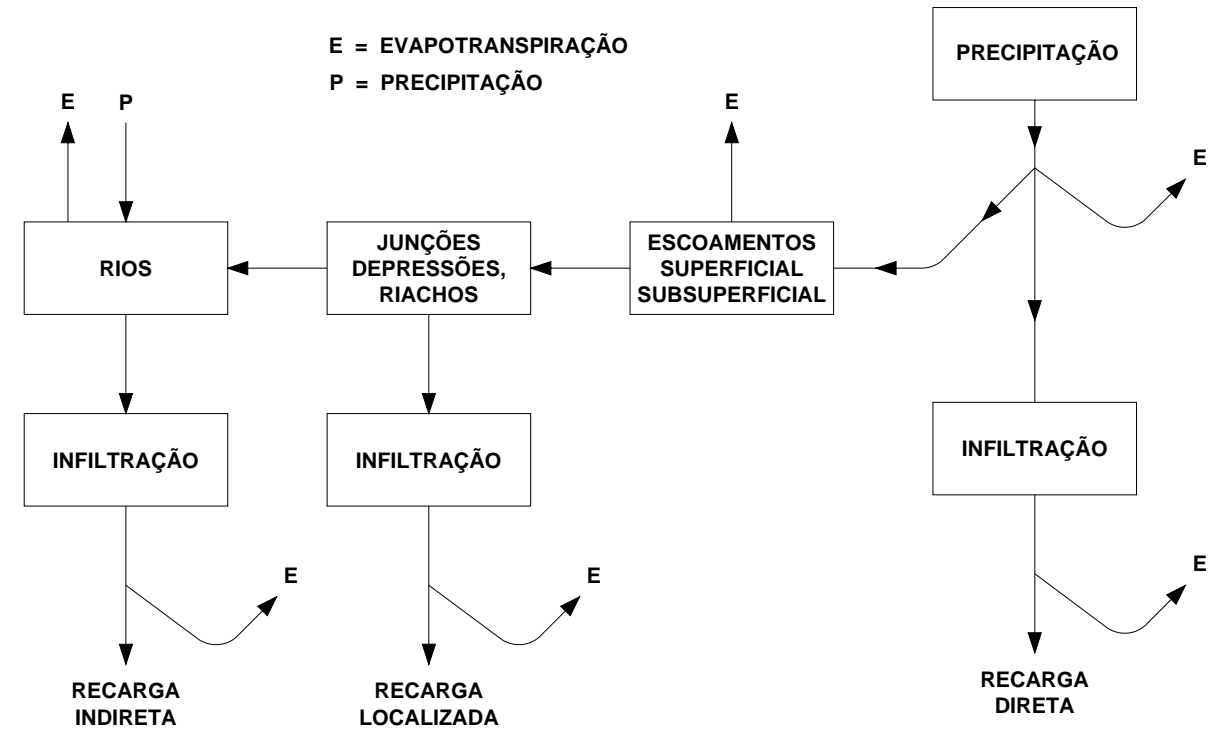

Figura 4 - Mecanismos de infiltração (LERNER, 1990)

As definições dos tipos de recarga circunstanciados por LERNER et al. (1990), segundo os próprios autores, são mais adequadas a regiões secas. Nessas regiões, os solos são geralmente rasos, com evapotranspiração elevada após a infiltração, e os rios intermitentes recarregam o aqüífero (rio influente). Assim, adaptando-se as definições anteriores às características de umidade da área de estudo deste trabalho (Figura 5), seguem:

a) a recarga direta corresponde ao fluxo descendente de água, que atinge o nível freático do Aqüífero Guarani em suas regiões de afloramento;

b) a recarga indireta corresponde à recarga, por drenança, fornecida ao Aqüífero Guarani através das camadas semiconfinantes, compostas principalmente pela Formação Serra Geral. Ela é fiel à definição de fluxo de macro-poro, descrita em de VRIES e SIMMERS (2002), que a estabelece como fluxo descendente de água através de falhas e fissuras; 


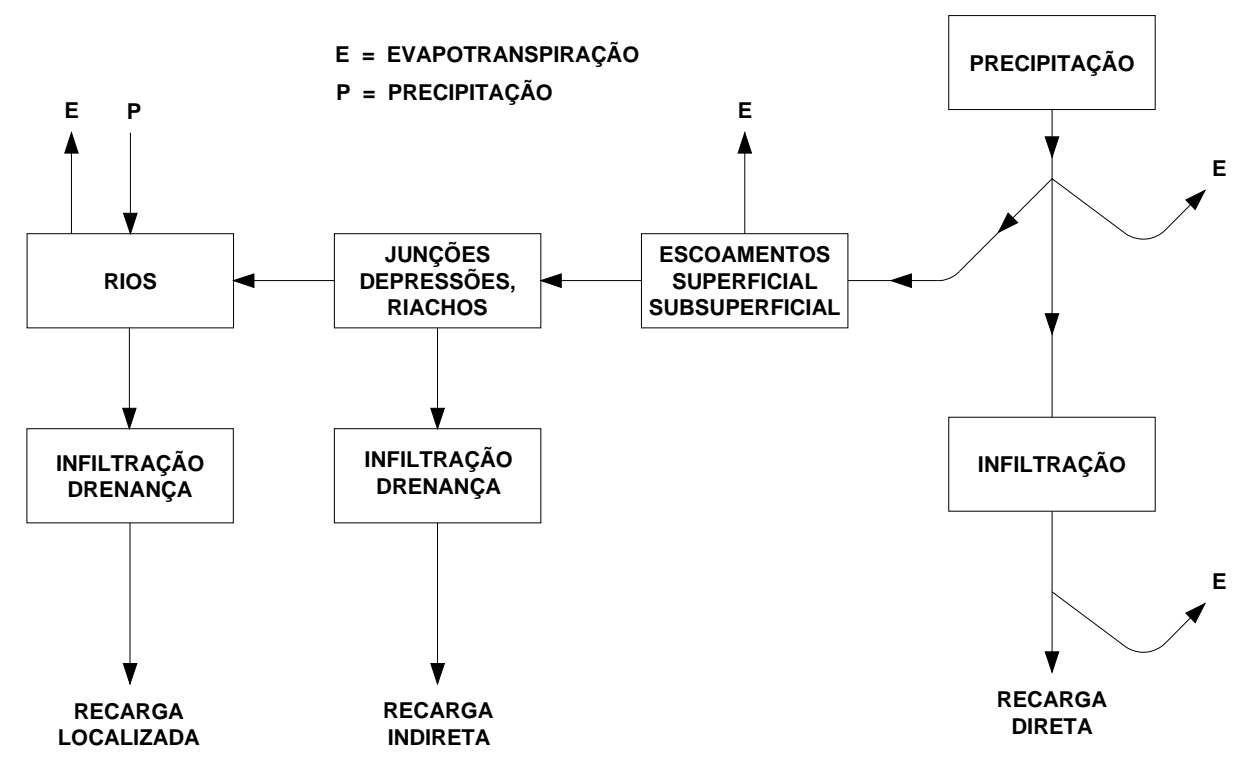

Figura 5 - Mecanismos de infiltração, característicos da área de estudo

c) a recarga localizada, diferentemente da definição de LERNER et al. (1990), tem uma origem diferente na área de estudo. Por pertencer a uma região úmida, os rios são carregados pelo aqüífero em sua maioria, podendo localmente, em condições favoráveis de diferença piezométrica rio-aqüífero, drenar água ao aqüífero através de falhas e fissuras dos basaltos nos leitos dos rios da região, caracterizando uma recarga localizada. CONTIM NETO (1987), analisando a interação rio-aqüífero na área de estudo, concluiu que estas áreas de recarga localizadas podem variar em intensidade e em extensão, ao longo do tempo, devido a variações sazonais do nível piezométrico.

A seguir, mais algumas definições de recarga são apresentadas e discutidas.

A recarga sobre uma certa área é, comumente, igualada à infiltração excessiva sobre essa mesma área. Entretanto, a água decorrente desse excesso, não necessariamente atinge o nível freático e/ou passa a compor o aqüífero, podendo se converter em escoamento subsuperficial, em seguida, superficial e, posteriormente, evapotranspirada. Este processo determina a quantidade potencial de água que, através do solo, pode (ou não) alcançar a zona saturada (recarga potencial), e a que realmente atinge o aqüífero (recarga real). O termo recarga potencial foi introduzido por RUSHTON (1988) apud de VRIES e 
SIMMERS (2002), definido como o excesso de precipitação, a mais da evapotranspiração, o qual, pode sair por algum sistema local de descarga ou por evaporação da zona saturada, mas pode tornar-se recarga "permanente" do aqüífero. Entre as dificuldades de se estabelecer as recargas potencial e real, estão a de identificar os sistemas locais de descarga e decidir o intervalo de tempo (entre recarga e evapotranspiração), segundo o qual, a incorporação da água ao aqüífero caracteriza melhor um dos dois tipos de recarga.

Em HEALY e COOK (2002) é utilizada a terminologia net recharge, referida comumente como recarga efetiva, a qual corresponde à variação do armazenamento do aqüífero, após tempo suficiente para refletir o efeito dos demais elementos do seu balanço hídrico, descrito adiante. A diferença entre a recarga real e efetiva é igual à soma da evapotranspiração do aqüífero, fluxo de base e fontes. Em termos espaciais, a recarga efetiva corresponde à parte da recarga real que sai do aqüífero apenas fora do seu domínio (do aqüífero). Na área de estudo (Aqüífero Guarani), a recarga efetiva foi estimada em 1,5\% da precipitação, por CORRÊA (1995).

Não obstante a variedade de processos envolvidos na recarga, bem como, a sua sensibilidade aos diversos fatores, investigados por diversos trabalhos, acima mencionados, a recarga mantém características previsíveis em relação a alguns parâmetros naturais mais gerais:

a) nas regiões úmidas, a recarga ocorre preferencialmente nas áreas topograficamente elevadas e a descarga nas regiões mais baixas (rios e lagos), enquanto nas regiões pouco úmidas, a recarga ocorre em áreas mais baixas (canais e cursos efêmeros), com descarga subterrânea;

b) a recarga é, geralmente, menor em regiões vegetadas, que em não vegetadas. Áreas irrigadas podem contribuir com quantidades significativas de recarga, dependendo das características das culturas, manejo e solo;

c) a recarga em regiões menos úmidas é muito mais susceptível aos efeitos climáticos. Nessas regiões, à medida que as taxas de evapotranspiração e precipitação aproximam-se entre si, a recarga se torna mais dependente de chuvas intensas (esporádicas) e de características do solo (recarga clima/solodependente). Diferentemente, segundo SANFORD (2002), em regiões mais úmidas, ou de relevo mais baixos, a espessura da zona não saturada é pequena e a taxa de recarga tende a ser controlada pela quantidade de água que o 
aqüífero pode transmitir entre suas regiões de recarga e descarga (recarga transmissão-dependente), onde a transmissão é controlada pelas características hidrogeológicas.

\subsubsection{Métodos de quantificação de recarga}

Os métodos que estimam a recarga de aqüíferos são classificados, segundo vários aspectos, por diversos autores (KINZELBACH et al., 2002; SCANLON et al., 2002). Considerando-se o meio hidrológico, no qual as informações de recarga são obtidas, os métodos podem ser classificadas como pertencentes a três zonas (ou grupos): saturada, não saturada e de águas superficiais. Em cada um dos grupos, os métodos podem ser classificados como: físico, de traçador e de modelo computacional.

A Tabela 4 discrimina os métodos mais significativos, especificando sua adequação em relação ao clima. KINZELBACH et al. (2002) atribuiu para alguns métodos ordens de precisão, distribuídas em três classes, baseadas nas magnitudes dos erros associados: classe 1 - até um fator 2, classe 2 - até um fator 5 e classe 3 - até um fator 10 ou superior.

Tabela 4 - Adequação de métodos de estimativa de recarga (KINZELBACH et al., 2002; SCANLON et al., 2002)

\begin{tabular}{|c|c|c|c|c|}
\hline \multirow{2}{*}{ Zona } & \multirow{2}{*}{ Técnica } & \multirow{2}{*}{ Classe } & \multicolumn{2}{|c|}{ Clima } \\
\hline & & & Seco & Úmido \\
\hline \multirow[t]{5}{*}{ Água superficial } & Balanço Hídrico do Canal & $2-3$ & 国 & 凶 \\
\hline & Medidores de Seepage & - & 凶 & $\boldsymbol{x}$ \\
\hline & Modelos de Bacias & - & 凶 & 凶 \\
\hline & Traçadores isotópicos & 3 & 凶 & 凶 \\
\hline & Descarga de Base & 1 & & 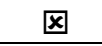 \\
\hline \multirow[t]{6}{*}{ Não-saturada } & Lisímetros & 1 & 可 & 可 \\
\hline & Plano de Fluxo Zero & - & 冈 & 凶 \\
\hline & Lei de Darcy & 3 & 凶 & 凶 \\
\hline & $\begin{array}{l}\text { Traçadores [histórico }-\left({ }^{36} \mathrm{Cl},{ }^{3} \mathrm{H}\right) \text {, } \\
\text { ambiental }(\mathrm{Cl})]\end{array}$ & $2-3$ & 凶 & \\
\hline & Traçadores Aplicados & $2-3$ & & 冈 \\
\hline & Modelagem Numérica & - & $\mathbf{x}$ & 凶 \\
\hline \multirow[t]{5}{*}{ Saturada } & Flutuação do Nível Freático & $2-3$ & & 凶 \\
\hline & Lei de Darcy & 3 & & 冈 \\
\hline & Traçadores [históricos $\left.-\left(\mathrm{CFCs},{ }^{3} \mathrm{H} /{ }^{3} \mathrm{He}\right)\right]$ & $2-3$ & 凶 & 凶 \\
\hline & Traçadores ambientais $\left(\mathrm{Cl},{ }^{14} \mathrm{C}\right)$ & 3 & $\mathbf{x}$ & \\
\hline & Modelagem Numérica & - & 凶 & 可 \\
\hline
\end{tabular}

冈 Adequado; ( ) Inadequado; (-) Sem classificação 
Diversos desses métodos de recarga são baseados na relação de balanço hídrico. Uma das maneiras mais comuns de estimá-la é aplicar o balanço hídrico sobre o domínio estudado, no qual, a recarga é expressa a partir dos demais componentes do balanço (método de recarga residual), medidos ou supostamente conhecidos. No balanço, a recarga pode ser expressa em função dos componentes extra-aqüífero (Relação 1) ou do aqüífero (Relação 2):

$$
R=P+Q_{i n}^{s w}-R_{0}-E T^{s w}-E T^{u z}-\Delta S^{s w}-\Delta S^{u z}
$$

no qual, $R$ é a água que atinge a zona saturada (recarga real), $P$, a precipitação, $Q_{i n}^{s w}$, o fluxo superficial de entrada, $R_{0}$, o fluxo superficial de saída (runoff), $E T^{s w} \mathrm{e}$ $E T^{u z}$, a evapotranspiração nos mananciais de superfície e na zona não saturada, respectivamente, $\Delta S^{s w}$ e $\Delta S^{u z}$, as variações do armazenamento nos meios indicados;

$$
R=Q_{\text {out }}^{g w}-Q_{i n}^{g w}+Q^{b f}+E T^{g w}+\Delta S^{g w}
$$

no qual, $Q_{i n}^{g w}, Q_{o u t}^{g w}, E T^{g w}$ e $\Delta S^{g w}$ são os fluxos de entrada e saída, evapotranspiração e variação do armazenamento, respectivamente, no aqüífero, e $Q^{b f}$, o fluxo de base.

A principal vantagem do método é a de não utilizar pressuposições relacionadas aos mecanismos de controle dos componentes do balanço, permitido aplicá-lo sobre amplas variações de escalas de espaço e tempo (centímetros e segundos a quilômetros e séculos). Como desvantagem, a precisão da recarga depende da precisão da medição (ou estimativa) dos demais elementos do balanço. Métodos diversos são utilizados para determinação de seus componentes (CEY et al., 1988; LINSLEY e FRANZINI, 1978; HILLEL, 1980). Valores pequenos de recarga, em comparação aos demais elementos do balanço (sobretudo a ET), resultam em grande incerteza na determinação da recarga residual, o que contraindica o método para regiões de baixa umidade (SCANLON et al., 2002). 
Para cada método, existem restrições de escalas de espaço, tempo e fluxo, bem como, de adequação e incerteza. SCANLON et al. (2002) sistematizou os limites de aplicação de alguns dos métodos mais significativos, em relação aos três aspectos de restrição (Figura 6).

A despeito da variedade de métodos, existem algumas características gerais a se considerar. Os métodos baseados em águas superficiais e em zona saturada são mais aplicáveis a regiões de clima úmido, enquanto os métodos de zona não-saturada, a regiões áridas. Os métodos baseados em zona nãosaturada, geralmente, estimam recargas sobre pequenas áreas, diferentemente dos métodos baseados nas duas outras zonas. Os métodos baseados em zona saturada, originalmente estimam a recarga com maior confiança que os métodos baseados nas outras zonas, devido ao fato dos métodos baseados em zona saturada estimarem a recarga real, enquanto os métodos baseados nas outras zonas, estimarem a recarga potencial. A seguir, os métodos são tratados sucintamente. 

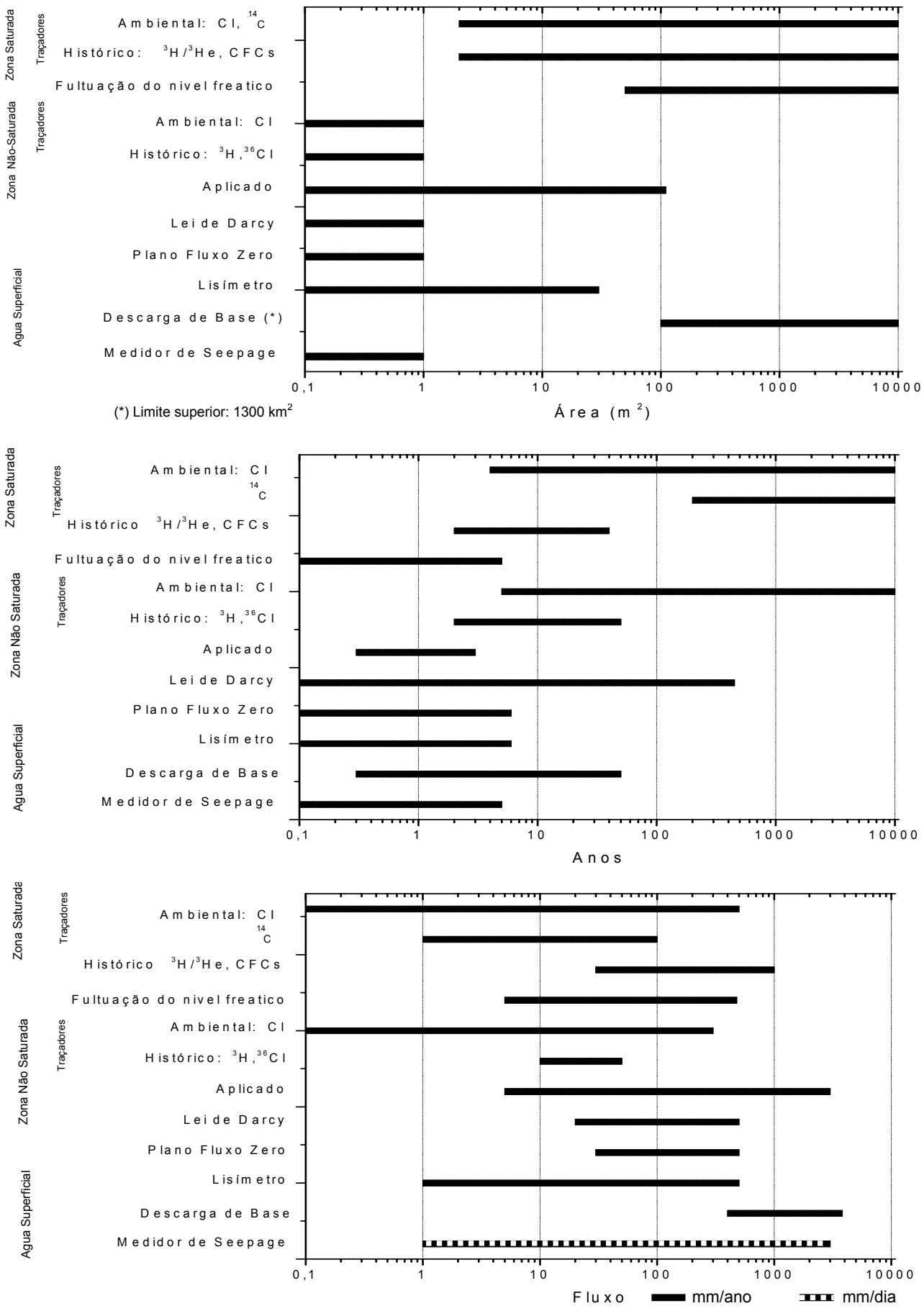

Figura 6 - Limites de sensibilidade dos métodos às estimativas de recarga, em relação ao tempo, espaço e fluxo, segundo SCANLON et al. (2002) 


\subsubsection{Métodos de traçadores}

O uso de traçadores permite as estimativas de recarga ao longo dos maiores intervalos de tempo, contudo, apresentam a desvantagem de não permitir a obtenção de informações sobre a variação da recarga ao longo do processo. Seu uso requer também uma boa estimativa da porosidade, a qual é relativamente fácil em meios não consolidados, porém, difícil em meios fraturados. As determinações nas zonas não saturadas geram informações localizadas de recarga. A seguir, são apresentados alguns métodos de traçadores mais significativos.

A. Traçador ambiental de zona não saturada

O uso do traçador conservativo no meio não-saturado, cloreto $(\mathrm{Cl})$, se baseia na presença do $\mathrm{Cl}$ na precipitação (proveniente de aerossol salino do mar) e do aumento de sua concentração no solo, devido à evaporação. A partir de seu balanço de massa, estima-se a recarga a partir das determinações de concentração de $\mathrm{Cl}$ no meio não-saturado e na chuva:

$$
P C_{p}=D C_{u z} \quad D=\frac{P C_{p}}{C_{u z}}
$$

no qual, $C_{p}$ é a concentração na precipitação $P, D$ é a drenagem estimada do meio não-saturado, de concentração $C_{u z}$. É o método capaz de medir as menores taxas de recarga, e sua incerteza aumenta fortemente com o crescimento do fluxo de recarga, devido à diminuição da sensibilidade da concentração de $\mathrm{Cl}$. O método é adequado a regiões de clima seco, podendo também ser aplicado ao meio saturado. Quando aplicado numa mesma área, normalmente estima valores de recarga ligeiramente maiores que na zona não saturada, devido à presença de fluxos preferenciais (JOHNSTON, 1987). O método tem como desvantagens: a interferência na concentração de cloretos no solo devido à presença de minerais e vegetação; a indisponibilidade de séries de 
concentração de $\mathrm{Cl}$ na chuva (alguns trabalhos utilizam séries de 3 a 10 anos) (KINZELBACH et al., 2002).

\section{B. Traçador ambiental de zona saturada}

Em aqüíferos confinados, o fluxo horizontal pode ser estimado por datação da água por ${ }^{14} \mathrm{C}$ em diversos pontos. A velocidade, $v$, pode então ser estimada entre isócronas do aqüífero (SILVA, 1983), e a recarga, $R$, estimada por:

$$
R=v n A / S
$$

na qual, $A$ e $S$ são as áreas da secção transversal e da zona de recarga do aqüífero, respectivamente, e $n$ a porosidade. Com meia-vida elevada (5200 anos), o ${ }^{14} \mathrm{C}$ determina tempos de residência longos. Devido a isso, as informações obtidas, não são relevantes como informações atuais de recarga (KINZELBACH et al., 2002).

\section{Traçadores aplicados à zona não saturada}

Os traçadores (químicos ou isotópicos) aplicados superficialmente (ou subsuperficialmente) ao solo são carreados pela infiltração da chuva ou irrigação. Com a determinação da velocidade do pico de concentração do traçador, através do perfil da zona não saturada, juntamente com a respectiva umidade média do solo (acima do pico), estima-se a taxa de recarga, $R$ :

$$
R=v \theta=\frac{\Delta z}{\Delta t} \theta
$$

na qual, $v$ é a velocidade do pico de concentração na profundidade $\Delta z$, após o intervalo de tempo, $\Delta t$, decorrido da aplicação e $\theta$ é o conteúdo volumétrico de água. Entre os traçadores, o trítio $\left({ }^{3} \mathrm{H}\right)$, o brometo e os corantes são os mais aplicados (RICE et al., 1986), principalmente os dois últimos, por serem mais baratos e terem menor restrição ambiental. Como principais limitações, podem ser aplicados apenas localmente e em áreas restritas, portanto, mais sujeitos a fluxos preferenciais, contudo, é ainda o método de maior alcance espacial entre os que utilizam traçadores na zona não saturada (SCANLON et al., 2002); o perfil no solo 
pode ser acompanhado até pequenas profundidades (aproximadamente $1 \mathrm{~m}$, caso do brometo), não sendo, portanto, adequada a utilização em regiões áridas.

\section{Traçadores históricos de zona não saturada}

Traçadores, geralmente resultantes de eventos globais, como testes nucleares, são descritos como traçadores históricos, p.ex ${ }^{3} \mathrm{H}$ e ${ }^{36} \mathrm{Cl}$, gerando picos de concentração na atmosfera e, levada ao solo pela água. Aplicáveis apenas à zona não saturada, a utilização desses traçadores é descrita pelo mesmo formalismo dos traçadores aplicados manualmente ao solo. Entretanto, diferentemente dos últimos, o perfil de concentração pode ser acompanhado a profundidades, teoricamente, só limitadas pela superfície do meio saturado. A máxima taxa de recarga estimada é condicionada a esse limite, entretanto, restrições operacionais para coleta de amostras, a profundidades elevadas, a tornam inadequada para estimativas muito superiores a $50 \mathrm{~mm} / \mathrm{ano}$. A avaliação espacial é localizada. (SCANLON et al., 2002).

E. Traçadores históricos de zona saturada

Os CFCs (clorofluorcarbonetos) e ${ }^{3} \mathrm{H} /{ }^{3} \mathrm{He}$ (trítio/hélio-3) são os traçadores (históricos) mais utilizados (COOK et al., 1998). Por meio deles, a recarga é estimada pela datação das águas do aqüífero - a idade é o tempo decorrido desde a entrada da água no meio saturado. Com os CFCs, a datação é feita pela comparação de suas concentrações na chuva e no aqüífero, enquanto a razão, ${ }^{3} \mathrm{H} /{ }^{3} \mathrm{He}$, é determinada pelo decaimento do trítio em hélio, ao longo do percurso. Em aqüíferos livres, a idade das águas cresce com a profundidade e a velocidade vertical diminui com a profundidade. A taxa de recarga é estimada, datando-se a água em vários pontos do perfil e determinando-se o gradiente de velocidade vertical:

$$
\frac{d t}{d z}(\text { determinado }) \rightarrow \frac{d z}{d t}=v \quad R=v_{s} n
$$

no qual, $t$ é a idade da água, $z$, a profundidade, $n$, a porosidade, $R$, a recarga, $v$, a velocidade vertical e $v_{s}$, a velocidade vertical no nível freático. Entre as desvantagens, os CFCs são pouco solúveis em climas quentes e o método 
encontra-se ainda em desenvolvimento, (KINZELBACH et al., 2002); a tomada de amostras é complexa e cara, em comparação a outros métodos.

\subsubsection{Métodos físicos}

\section{A. Plano de fluxo-zero}

Descrito primeiramente por Richards (1956), o método se baseia na existência de um plano limiar para a água ser evapotranspirada ou drenada. Este plano, onde teoricamente o fluxo é zero, separa as regiões do solo de fluxos ascendentes e descendentes. Para implementar esse método, são necessárias medidas do potencial da matriz, ao longo do perfil do solo não-saturado (para localização do plano), e do conteúdo de água no solo sob o plano para estimar a recarga. Tecnicamente, apresenta dificuldades para localização do plano, quando da presença de frentes descendentes de umidade (SCANLON et al., 2002). A avaliação espacial da recarga é localizada.

\section{B. Lisímetro}

Projetado para medições diretas de drenagem, o lisímetro consiste num recipiente que, preenchido com solo (vegetado ou não) e localizado sob o nível do terreno, pode estimar a recarga local através do meio não-saturado. Aplicando-se o balanço hídrico, estima a ET por meio de medições (em separado) de precipitação e umidade do solo. O fluxo mínimo que pode ser medido depende do seu sistema de drenagem e de sua área superficial (normalmente de 2 a $10 \mathrm{~m}^{2}$ ). Não é adequado a regiões de zona radicular profunda, o que leva a superestimar a recarga. Devido ao restrito alcance e à limitação na mobilidade, os lisímetros são menos utilizados para estimar recarga e mais para estimar ET, servindo como referência para comparação entre diferentes métodos (WENDLAND e CUNHA, 2003).

C. Medidores de seepage (infiltrômetros)

Este método consiste, geralmente, num cilindro parcialmente fincado no leito de ribeirões, visando medir diretamente o fluxo entre o aqüífero e o pequeno 
rio, através do leito. Por ser um método bastante localizado, devido às pequenas dimensões do dispositivo de captação (geralmente inferior a $1 \mathrm{~m}^{2}$ ), estima muito localmente a recarga. Em CEY et al. (1998), cinco métodos (incluindo traçadores, físicos e de água superficial) foram utilizados para comparação entre si, tendo, apenas o método de seepage, falhado na estimativa de recarga de um pequeno canal.

\section{Lei de Darcy}

Para estimar a recarga, pode-se utilizar a Lei de Darcy em meio nãosaturado (tanto em regiões de clima seco, como úmido), bem como, em meio saturado. No meio não-saturado a recarga $R$ é dada por:

$$
R=-K(\theta) \frac{d h}{d z} \quad \operatorname{com} \quad \theta=\theta(\psi) \quad \text { e } \quad h=\psi+z
$$

na qual, $K$ é a condutividade hidráulica, $h$, a carga total, $\psi$, o potencial da matriz, $z$, a coordenada vertical e $\theta$, o conteúdo de umidade. Sua aplicação requer medidas (ou estimativas) do gradiente vertical de carga, bem como, da condutividade no perfil do solo. A determinação (em laboratório) da condutividade é particularmente difícil, devido a heterogeneidade, variação com a umidade e sistema de coleta de amostras. Apesar de ser um método local, se a espessura da zona vadosa for grande e o método for aplicado em profundidades maiores, pode estimar a recarga representativa de áreas significativas (SCANLON et al., 2002).

Em meio saturado, a recarga $R$ é estimada por:

$$
R=q A / S \quad \text { para } \quad q=-K \frac{d h}{d x}
$$

na qual, $A$ é a seção transversal do aqüifero, $S$, a área de contribuição da recarga, $K$ e $\frac{d h}{d x}$ a condutividade e o gradiente hidráulico do meio saturado, respectivamente. O gradiente hidráulico é, na prática, calculado entre contornos potenciométricos. A recarga por esse método é incerta, principalmente, pela 
variabilidade de $K$ e dificuldade de determinar os parâmetros geométricos com exatidão.

E. Flutuação do nível freático

O método se baseia na premissa de que, a recarga do aqüífero livre é inteiramente atribuída à elevação do seu nível freático, $\Delta h$, (correspondente à variação do armazenamento $\Delta S^{g w}$ ), não sendo computado o efeito sobre os demais componentes do balanço hídrico (Relação 2). Assim, considerando-se um intervalo de tempo $(\Delta t)$, pequeno o suficiente para que essa premissa seja válida, se expressa a recarga $R$ como:

$$
R=S_{y} \frac{\Delta h}{\Delta t}
$$

na qual $S_{y}$ é o rendimento específico. Aplicável apenas a aqüíferos livres, o método é mais indicado quando aplicado em níveis freáticos rasos, que variam muito e rapidamente (horas a alguns dias). A recarga total, ao longo de um período longo, é computada somando-se as contribuições individuais de cada evento. A estimativa de recarga pode considerar o efeito sobre grandes áreas (milhares de $\mathrm{m}^{2}$ ), entretanto, o método não é válido em "situações estacionárias", onde a recarga é constante e igual à drenagem do nível freático (HEALY e COOK, 2002). Incerteza é imputada ao método pela dificuldade de determinar o rendimento específico com exatidão.

\section{F. Descarga de base}

Em regiões de clima úmido, a drenagem das bacias é formada por rios mantidos com a recarga dos aqüíferos (descarga de base). Nesses casos, é possível estimar a recarga do aqüífero a partir das informações de descarga dos rios, visando separar a parte referente à contribuição das águas subterrâneas. $\mathrm{O}$ método pressupõe que, a condição de baixos fluxos nos rios corresponde à descarga do aqüífero. Diversas técnicas existem para implementar essa tarefa a partir da análise de hidrogramas. Além das técnicas manuais (geométricas), p.ex., Smoothed Mínima (IH, 1980), diversas técnicas analíticas, p.ex., Recursive Digital 
Filter (NATHAN e McMAHON, 1990) e Deslocamento da Curva de Recessão, que estima diretamente a recarga (RORABOUGH, 1964), foram propostas. Embora as técnicas analíticas sejam baseadas em considerações físicas, utilizam elementos subjetivos para a separação.

ARNOLD et al. (1995) encontraram, para a bacia do Upper Mississipi, boa coincidência entre as recargas calculadas pela técnica Deslocamento da Curva de Recessão e pelo método de balanço hídrico, utilizando modelo de bacias (156 $\mathrm{mm} /$ ano e $148 \mathrm{~mm} / \mathrm{ano}$, respectivamente).

Segundo KINZELBACH et al. (2002), os métodos que utilizam separação de fluxo de base são "um dos poucos e, provavelmente, os melhores métodos disponíveisl" para estimativas regionais de recarga em regiões úmidas. Entretanto, SCANLON et al., 2002, reporta-se à adequação do método ao tamanho das bacias. Segundo este trabalho, $1.300 \mathrm{~km}^{2}$ é a área máxima recomendável, devido à dificuldade em se distinguir, nos hidrogramas, o fluxo superficial e subterrâneo, do efeito de armazenamento (bankstorage) em grandes sistemas, bem como, devido à consideração de recarga uniforme.

\subsubsection{Métodos de modelo computacional}

\section{A. Modelos de bacias}

Também conhecidos como modelos de chuva-vazão, geralmente, estimam a recarga como um termo residual do balanço hídrico (Relação 1), podem ser aplicados em escala regional e são mais precisos em regiões úmidas, devido à possibilidade de calibração do modelo a partir de fluxos superficiais perenes (SCANLON et al., 2002). Podem ser usados em qualquer escala de tempo e espaço, limitadas pela precisão e alcance dos dados dos componentes do balanço hídrico.

\section{B. Modelos de zona não saturada}

Estimam a recarga, teoricamente, para todos as profundidades da zona vadosa, utilizando comumente soluções numéricas da equação de Richards. As simulações podem ser implementadas sobre quaisquer condições de solo, clima e 
vegetação (KINZELBACH et al., 2002). A quantidade elevada de parâmetros envolvidos como dados de entrada limita a confiabilidade das predições. Normalmente é necessária a comparação dos resultados por outros métodos, como lisímetros e traçadores.

\section{Modelos de aqüíferos}

A recarga estimada em modelos de fluxo de aqüíferos podem ter diferentes abordagens, a depender das características do modelo conceitual implementado numericamente. Entre esses aspectos, estão a dimensionalidade adotada (1D, 2D ou 3D), as características consideradas de confinamento e as formas como são distribuídos os parâmetros e variáveis utilizados na sua determinação, p.ex., condutividade hidráulica, carga hidráulica, coeficientes de recarga (em relação à precipitação), fluxos, fontes etc. De um modo geral, após rodar o modelo no modo direto, é preciso executar o modelo no modo inverso (ou calibração do modelo direto), buscando obter a recarga por meio do ajuste entre os resultados, gerados pelo modelo, e os valores observados. Segundo SANFORD, 2002, um problema de unicidade surge: devido à correlação entre a recarga e a condutividade hidráulica, resulta que, quando apenas os níveis da carga hidráulica são observados, só é possível estimar a relação entre ambos (recarga/condutividade). Assim, torna-se necessário ter informações sobre o fluxo, p.ex., o fluxo de base, para a obtenção de uma estimativa única de recarga. A incerteza, contudo, associada à estimativa da recarga, está associada não só ao modelo, mas a todo o sistema de dados. Uma avaliação especifica desses aspectos é descrita na seção seguinte.

\subsection{INCERTEZA NOS MODELOS DE ÁGUA SUBTERRÂNEA}

O estudo da hidrogeologia impõe algumas dificuldades adicionais em relação à hidrologia de superfície por motivos intrínsecos ao meio. Estes motivos estão todos relacionados às condições naturais que estabelecem especificidades ao entendimento do comportamento do fluxo subterrâneo e sua interação com o meio. As dificuldades adicionais, entretanto, longe de estabelecerem uma impossibilidade ao seu estudo, têm representado um desafio estimulante aos 
pesquisadores que se dedicam a desvendá-las ao longo de décadas. Tal interesse é plenamente justificado pela importância dos recursos hídricos subterrâneos (manancial e fluxo) para as atividades sócio-econômicas e ao estudo de conseqüências ambientais.

Considerando comumente grandes extensões como objeto de estudo, bem como, a variabilidade espacial do meio e o elevado custo de medições pontuais numerosas, o estudo sobre o manancial subterrâneo dá-se por um enfoque, em geral, menos hidráulico e mais hidrológico. Por estas razões está sujeito principalmente a determinações indiretas de seus parâmetros, variáveis e condições de contorno. Assim, a hidrogeologia - representada pela hidrologia de aqüíferos - se caracteriza por abarcar um vasto e fértil campo propício à aplicação de simulações e modelos dos mais variados. A grande variabilidade natural dos parâmetros hidráulicos, teoricamente contínuos, vinculados às formações que permeiam o fluxo subterrâneo e às tensões hidrológicas, permite aos pesquisadores, numerosas considerações para simplificar este ambiente real, tornando efetivamente possível seu estudo como um todo. Essas simplificações compõem as bases do modelo conceitual adotado e implementado posteriormente pelo modelo matemático para simular o comportamento do aqüífero. A implementação desses modelos, entretanto, requer dados os quais, juntamente com os modelos conceitual e matemático, possuem incertezas associadas, quaisquer que sejam as configurações adotadas entre os mesmos. $O$ sucesso atribuído à execução desses modelos tem como um de seus parâmetros principais a avaliação das incertezas envolvidas nos seus dados e previsões.

O objetivo deste texto é identificar e avaliar as fontes de incerteza e de erro, que envolvem as etapas de construção e aplicação de modelos numéricos de fluxo em aqüíferos, abrangendo dados, modelo conceitual e modelo numérico.

\subsubsection{Fontes de incerteza associadas a informações prévias}

Os conceitos de erro e incerteza possuem significados distintos, todavia, estão muito ligados entre si. A relação muito próxima entre ambos faz surgir, freqüentemente, confusão na atribuição de valores. Numa definição informal, o 
erro na determinação de uma grandeza significa a diferença entre o valor real (verdadeiro) da grandeza e o valor resultante de sua determinação. $O$ valor verdadeiro de uma grandeza seria o valor obtido numa determinação perfeita. Obviamente, os valores verdadeiros são indetermináveis por natureza, o que leva a se recorrer a valores convencionalmente verdadeiros, conhecidos como "valor atribuído" ou "melhor estimativa". A incerteza, por sua vez, caracteriza o "grau de confiança" da determinação, sendo uma indicação dos limites máximos (superior e inferior) dos erros, que se supõe, possam ter sido cometidos na determinação da grandeza.

Considerando o exposto, é direcionada, nesta seção, a atenção às fontes de erro, entretanto, não apenas aos erros ligados a medições, mas também aos relacionados à concepção típica de modelos de fluxo aplicados à água subterrânea. Esses erros são discutidos a seguir, no processo de determinação de variáveis e parâmetros hidráulicos, na definição do modelo conceitual e no desenvolvimento e implementação do modelo numérico.

\subsubsection{Cargas hidráulicas}

Os valores de carga hidráulica $(h)$ sempre compõem o conjunto de informações a ser utilizado na implementação do modelo. Tratadas como variáveis, parâmetros, ou no estabelecimento de condições de contorno, são fundamentais na solução do problema direto ou em sua calibração. Em relação aos erros atribuídos à carga hidráulica, um conjunto de três origens pode ser identificado: as decorrentes dos instrumentos de medição, da operação ao estabelecer o nível da água, e da medição da elevação deste nível em relação ao nível de referência. No último conjunto, encontram-se duas das maiores fontes de erro, entre elas a decorrente da dificuldade de se determinar o nível estático do aqüífero a partir de poços ou piezômetros, em regiões onde existe grande interferência entre poços de bombeamento em atividade, ou recém desligados. Este efeito, quando em regiões de superexploração do aqüífero, leva a um rebaixamento conjunto do nível estático na região, provocado pela superposição dos cones de depressão. A segunda fonte de erro é proveniente de medições de 
níveis d'água de mananciais de superfície, como rios e lagos, com a intenção de atribui-los à carga hidráulica do aqüífero. Nestes casos, o erro decorre da incerteza da interação local rio-aqüífero, freqüentemente associada à complexidade litoestratigráfica.

Os dados com medidas de campo dos valores de $h$ podem refletir a presença de efeito transiente não previsto pelo modelo adotado. Tal efeito pode ser influenciado por diversos fatores como: tempo decorrido na tomada das medições, variação da pressão atmosférica, valores de recarga e descarga presentes na região de fluxo, bem como, valores de parâmetros hidráulicos e características geológicas.

Na implementação dos modelos numéricos, os valores de carga medidos pontualmente em poços ou piezômetros são atribuídos a células ou elementos da grade discretizada, representando regiões do espaço físico da área modelada. Entretanto, medidas de carga podem estar influenciadas por heterogeneidades de pequena escala, que transferidas para grandes regiões estabelecem erros na simulação das cargas. Esta fonte de erro é conhecida como efeito de escala (scaling effect) como discutido por GELHAR (1986).

Apenas devido às fontes instrumentais, sob condições "ideais" de experimento, ANDERSON e WOESSNER (1992) afirmam que os erros são da ordem de poucos centímetros. Apesar disso, estudos regionais podem gerar erros muito maiores a depender da precisão dos experimentos.

Freqüentemente os valores de $h$ são utilizados pelos modelos a partir de mapas de nível freático, e até, simplesmente, de mapas planialtimétricos. As incertezas envolvendo os valores de $h$ por estas fontes, principalmente em casos de grande escala, costumam ser maiores que quando determinados por experimentos de campo, considerando-se as respectivas fontes de erro. Assim, é recomendável, principalmente quando da simulação de grandes áreas, a utilização de pontos amostrais com valores de $h$ determinados em campo a partir de medidores de nível georeferenciados com altimetria. Esses valores assim obtidos servem para comparar dados já existentes e permitir avaliar melhor a qualidade dos dados de carga hidráulica fornecidos ao modelo, sobretudo, estabelecendo uma melhor qualidade a esses valores utilizados como referência no processo de calibração. 


\subsubsection{Fluxos}

As medidas de fluxo subterrâneo são, em geral, estimativas, uma vez que, com raras exceções de medições localizadas (medições de seepage em rios e lagos, CEY et al., 1998), fontes surgentes, fluxos de base, fluxo lateral resultante da contribuição entre aqüiferos vizinhos, CHERKAUER e McBRIDE (1988) - e fluxos através do nível freático, são todos métodos indiretos de determinação. Devido a isso, estimativas de fluxo têm sido associadas a erros maiores que as associadas a cargas hidráulicas (de VRIES e SIMMERS, 2002). Esses são alguns dos fluxos principais, cujos valores são utilizados como condições de contorno, condições internas ou restrições nos modelos para solução do problema direto ou inverso. Esses dados são obtidos por métodos indiretos específicos a cada tipo de fluxo e podem apresentar grandes desvios entre resultados de diferentes métodos possuindo mesmo objetivo, entretanto, pode-se obter uma faixa de variação plausível para os mesmos. Como exemplo, podem-se citar as conclusões sobre a determinação do fluxo de base obtidas a partir das técnicas indiretas, Recursive Digital Filter e Smoothed Minima, nos trabalhos de NATHAN e McMAHON (1990) e ARNOLD et al. (1995).

O fluxo através do nível freático estabelece a recarga direta do aqüífero, oriunda da precipitação, e é uma das mais importantes estimativas na definição do sistema de água subterrânea, podendo também estabelecer o volume de água que ascende do aqüífero diretamente à zona não-saturada (oriunda da evapotranspiração) e à superfície (descarga). Apesar de sua importância, não existe um método universalmente reconhecido para estimá-lo em decorrência do sucesso limitado dos mesmos. Esses métodos podem ser caracterizados em dois grandes grupos: os que são baseados em modelos de balanço hídrico do aqüífero (STOERTZ e BRADBURY, 1989), e os que são baseados em modelos da zona não-saturada (KRISHNAMURTHI et al., 1977). A idéia geral do primeiro grupo é de que as cargas do nível freático são especificadas em todas as células, ou nós, do seu domínio, e o cálculo do balanço hídrico entre essas e as células vizinhas estabelece o fluxo entre as mesmas. A diferença entre o fluxo que entra e que sai de todas as células do nível freático estabelece as taxas de recarga, ou descarga, que devem ocorrer verticalmente através do mesmo. A incerteza dos métodos 
que utilizam essa abordagem está relacionada fortemente aos erros de interpolação dos valores de carga do nível freático e dos valores atribuídos à condutividade hidráulica. Em relação ao segundo grupo, os métodos se caracterizam por estimar a recarga a partir de dados de precipitação e infiltração locais, através da zona não-saturada (ANDERSON e WOESSNER, 1992). Entre os dados necessários para sua estimativa, constam as informações de clima, solo e vegetação, enquanto o modelo deve ser capaz de considerar os principais fluxos envolvidos, entre a precipitação na superfície e o nível freático do aqüífero (Figura 7).

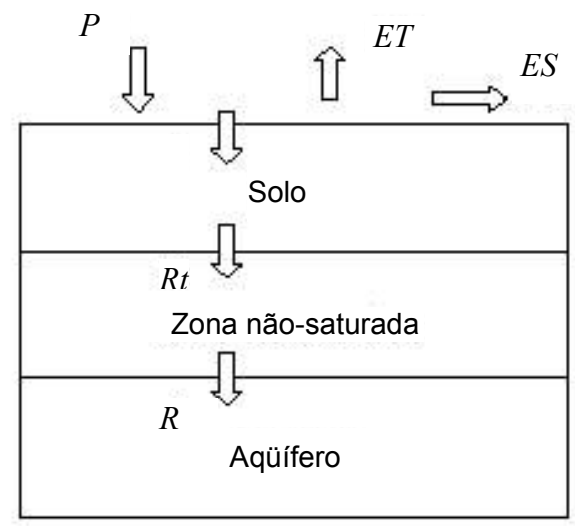

Figura 7 - Esquema conceitual de fluxos entre a superfície e o aqüífero, no qual: $P$ - precipitação, ET - evapotranspiração, $E S$ - escoamento superficial, $R t$ recarga em trânsito e $R$ - recarga do aqüífero

Ambas as abordagens precisam de dados em quantidade e qualidade suficientes à calibração dos modelos. Assim, incertezas adicionais podem ser atribuídas à estimativa do fluxo através do nível freático:

a) aqüíferos com características comuns, aprestam, em geral, significativas variações espaciais e temporais nas taxas de recarga e descarga através do nível freático (STEENHUIS et al.,1985 e STOERTZ e BRADBURY, 1989), entretanto, devido às dificuldades de obtenção de dados que permitam estabelecer essas taxas para toda a área de interesse, é usual atribuir uma distribuição espacial uniforme da taxa de recarga a um valor percentual da precipitação anual média. Resultados da calibração de modelos de fluxo mostram, em geral, melhores resultados quando os mesmos incorporam a variação espacial da recarga por zonas, procedimento este tornado comum a partir da segunda metade da década de 1980 (ANDERSON e WOESSNER, 1992); 
b) efeitos de escala, produzidos pela inadequada discretização da malha e zoneamento dos dados de precipitação. Tal efeito pode estimar, até mesmo, valores inversos de fluxo através de regiões do nível freático em comparação com a estimativa realizada por discretização da malha e zoneamento de precipitação mais adequados.

\subsubsection{Parâmetros hidráulicos}

As informações prévias acerca dos parâmetros hidráulicos, condutividade hidráulica $(K)$, transmissividade $(T)$ e coeficientes de armazenamento $\left(S_{X}\right)$, são normalmente obtidas de testes de condutividade hidráulica e principalmente de teste de bombeamento e recuperação, envolvendo um ou mais poços. A determinação de valores de condutividade hidráulica realizada a partir de medições hidrométricas de alcance pontual, como as decorrentes da medição direta de seepage (drenagem surgente) e de slug-test (teste por elevação pontual da carga hidráulica em tubo-teste) ou utilizando mini piezômetros, conduzem freqüentemente a resultados com grande variação da condutividade, mesmo em áreas próximas entre si, em conseqüência da heterogeneidade pontual dos solos (CEY et al., 1998). A interpretação dos testes de bombeamento que determina a transmissividade local $T$ também contém erros: assume usualmente a homogeneidade e isotropia na transmissividade de campo, possui erros na medição do rebaixamento, ou ascensão, do nível d'água no poço durante o teste. A interpretação é estabelecida por modelos teóricos que não representam corretamente as características do aqüífero. Na maioria dos casos, os valores de $K$ são obtidos indiretamente da relação $T=b . K$, na qual, $b$ é a espessura do aqüífero. Um dos maiores problemas, entretanto, é estabelecer o espaço do aqüífero sob influência do teste: se o teste é de curta duração, o espaço de influência pode ser da ordem de metros, se for de duração muito maior esta ordem pode ser de quilômetros. Mesmo conhecendo-se precisamente o tempo de duração do teste não é possível determinar o referido espaço de influência com exatidão, uma vez que, outras propriedades do meio interferem nesta determinação, p. ex., os coeficientes de armazenamento $S_{x}$, um parâmetro também a ser determinado e associado a incertezas, porém, normalmente, sujeito 
a variações muito menores que as de $T$. Contudo, sabe-se que dentro do espaço sob influência do teste, $T$ obtida por solução analítica é, para tempos longos de teste, a média geométrica das propriedades elementares do meio (MEIER et al., 1998). Se a permeabilidade das rochas for constituída por uma cadeia de fraturas interconectadas, o espaço no qual $T$ é determinada, pode se tornar extremamente grande ou potencialmente infinito. Sua região de influência é estimada em função da distribuição dos comprimentos da conectividade, como verificado no trabalho de BOUR e DAVY (1998).

Os valores de $T$ são disponíveis localmente em apenas alguns pontos do aqüífero, formando, p. ex., um conjunto de algumas dezenas em 1000 km². Além disso, independentemente dos erros discutidos, não é surpreendente este parâmetro variar de cinco ordens de grandeza em aqüíferos regionais, p.ex., de $10^{-3}$ a $10^{2} \mathrm{~m}^{2} / \mathrm{d}$. Por outro lado, é preciso determinar a priori os valores de transmissividade em um número comumente muito maior de pontos para levar a cabo o modelo na solução dos problemas direto ou inverso. Assim, torna-se necessário o "tratamento" dos dados experimentais. Segundo MONTENEGRO et al. (1999), a não-simetria dos valores de $T$, observada experimentalmente, tem levado a se considerar uma distribuição log-normal para a mesma, permitindo que $y=\log (T)$ seja usada como variável, tratando o problema de sua variação por uma abordagem gaussiana. A necessidade de se completar o conjunto de informações - principalmente os valores de carga e parâmetros hidráulicos - a serem alocados em todos os pontos requeridos pelo modelo, bem como, a necessidade de avaliar sua incerteza associada, tem levado ao uso da geoestatística, promovendo um melhor ajuste entre os resultados observados em campo e gerados pelo modelo.

Nas simulações transientes torna-se necessário estabelecer o valor de armazenamento para cada ponto da malha. As cargas hidráulicas variam como resultado da transferência de água armazenada no meio poroso, tornando a simulação estacionária quando este processo encerra; daí a necessidade do modelo em especificar o parâmetro que descreve a capacidade do aqüífero em transferir água do armazenamento. Esta capacidade, conhecida como armazenamento, é representada por um dos parâmetros seguintes: armazenamento específico $\left(S_{S}\right)$, coeficiente de armazenamento $(S)$ ou rendimento específico $\left(S_{y}\right)$. Numa descrição sucinta dos mesmos, o coeficiente de armazenamento específico $\left(S_{S}\right)$, usado em modelos tri-dimensionais, é igual ao 
volume de água liberado do armazenamento por volume unitário de meio poroso por unidade de declínio na carga hidráulica. O coeficiente de armazenamento $(S)$, usado em modelos bi-dimensionais, assumindo valores verticais médios, é igual ao volume de água liberado do armazenamento por unidade de área superficial do aqüífero por unidade de declínio na carga hidráulica, sendo, em aqüíferos confinados, $S=b S_{s}$. O rendimento específico $\left(S_{y}\right)$, utilizado em aqüíferos livres, é igual ao volume de água liberado do armazenamento por unidade de área por unidade de declínio na carga hidráulica. $S$ e $S_{S}$ medem o volume de água liberado da compressão da matriz do aqüífero e expansão da água, enquanto $S_{y}$ mede a água drenada pelo efeito gravitacional em resposta ao declínio do nível freático.

Os valores de armazenamento obtidos de situações de campo não são facilmente determinados, e os valores $S$ e $S_{y}$ obtidos de testes de bombeamento, sobretudo os de $S_{y}$ (NEUMAN, 1979), são sujeitos a erros. Contudo, a variação de qualquer dos parâmetros de armazenamento é relativamente pequena, comparada à variação da condutividade hidráulica (Figura 8, Tabela 5 e Tabela 6). Devido a esses aspectos, o armazenamento é, na pratica, estabelecido como uniforme em cada unidade hidroestratigráfica ${ }^{(1)}$ de um aqüífero ou camada confinante, eventualmente apresentando distribuição por zonas. Assim, a sua atribuição, uniforme ou estabelecida a partir de zonas, requer uma investigação iterativa entre os resultados do modelo numérico e as características observáveis e estimadas do aqüífero.

(1) Introduzida por MAXEY (1964) apud ANDERSON \& WOESSNER (1992), é a representação de estrutura ou camada com mesma característica hidráulica 


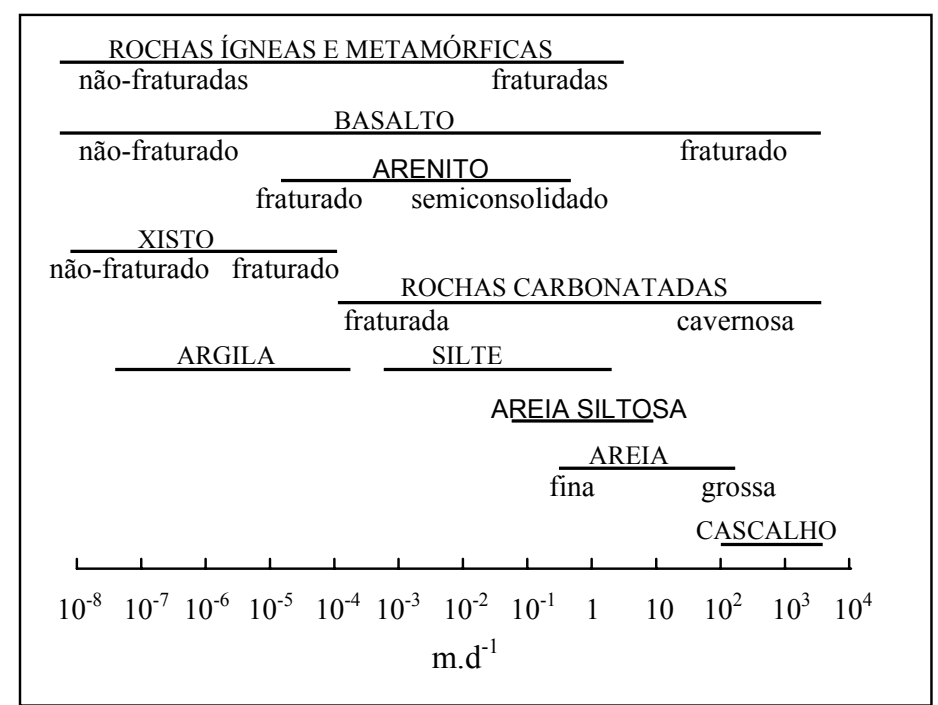

Figura 8 - Faixas de valor de condutividade hidráulica $\mathrm{K}(\mathrm{m} / \mathrm{dia})$ para diversos materiais (adaptado de HEATH, 1983)

Tabela 5 - Faixas de valor de armazenamento específico $\mathrm{S}_{\mathrm{s}}\left(\mathrm{m}^{-1}\right)$ para diversos materiais (adaptado de DOMENICO, 1972)

\begin{tabular}{l|c}
\hline \multicolumn{1}{c}{ Material } & Armazenamento especifico $S_{s}\left(\mathrm{~m}^{-1}\right)$ \\
\hline \hline Argila & $2,0 \times 10^{-2}-9,2 \times 10^{-4}$ \\
Areia pouco densa & $1,0 \times 10^{-3}-4,9 \times 10^{-4}$ \\
Areia densa & $2,0 \times 10^{-4}-1,3 \times 10^{-4}$ \\
Cascalho arenoso denso & $1,0 \times 10^{-4}-4,9 \times 10^{-5}$ \\
Rocha fissurada & $6,9 \times 10^{-5}-3,3 \times 10^{-6}$ \\
Rocha não-fissurada & menor que $3,3 \times 10^{-6}$ \\
\hline
\end{tabular}

Tabela 6 - Faixas de valor de rendimento específico $S_{y}$ para diversos materiais (adaptado de MORRIS e JOHNSON, 1967)

\begin{tabular}{l|c}
\hline \multicolumn{1}{c}{ Material } & Rendimento específico $S_{y}(-)$ \\
\hline \hline Arenito fino & $0,02-0,40$ \\
Arenito médio & $0,12-0,41$ \\
Areia fina & $0,01-0,46$ \\
Areia média & $0,16-0,46$ \\
Areia grossa & $0,18-0,43$ \\
Cascalho fino & $0,13-0,40$ \\
Cascalho médio & $0,17-0,44$ \\
Cascalho grosso & $0,13-0,25$ \\
Silte & $0,01-0,39$ \\
Argila & $0,01-0,18$ \\
Xisto & $0,22-0,33$ \\
Rocha calcárea & $0-0,36$ \\
\hline
\end{tabular}




\subsubsection{Erros na definição do modelo conceitual}

O objetivo do modelo conceitual é o de simplificar a situação real, considerando processos hidrológicos que permitam uma representação mais simples da geometria do aqüífero e das formações geológicas que compõem as unidades hidroestratigráficas. Teoricamente, entretanto, quanto mais fiel for o modelo conceitual ao sistema de campo, mais preciso poderá ser o seu modelo numérico, sendo crítica a relação entre simplificação e precisão. Falhas nas predições de modelos numéricos são freqüentemente atribuídas a erros no modelo conceitual. Esquematicamente, segundo ANDERSON e WOESSNER (1992), os erros atribuídos à construção do modelo conceitual podem ser identificados em três momentos: definindo as unidades hidroestratigráficas, o balanço hídrico e o sistema de fluxo.

i. Definindo as unidades hidroestratigráficas: as informações geológicas oriundas de mapas geológicos, mapas de seções transversais, construção de poços, juntamente com as informações das propriedades hidrogeológicas, e eventualmente testes geofísicos, permitem definir as unidades hidroestratigráficas. No processo de definição das unidades hidroestratigráficas, várias formações geológicas podem ser combinadas em uma única unidade estratigráfica ou uma formação geológica pode ser, p.ex., dividida em duas dessas unidades: aqüífero e camada confinante. Entretanto, para que estas unidades definidas representem corretamente o comportamento do aqüífero, é necessário que os parâmetros hidráulicos correspondentes sejam conhecidos. $\mathrm{Na}$ prática, muitas vezes esses dados são escassos e com elevada faixa de incerteza associada.

ii. Preparando os balanços hídricos: todo o sistema de fluxo (entradas e saídas) mais a variação do armazenamento, no domínio relacionado ao aqüífero, deve compor o modelo conceitual. Assim, uma estimativa de cada uma das contribuições de fluxo deve ser realizada, priorizando os dados com menor incerteza e sumarizando um balanço hídrico para mensurar inicialmente os fluxos e a variação no armazenamento hídrico do sistema aqüífero, este último, apenas para modelos transientes. Como visto, as determinações de fluxo em aqüíferos estão associadas, em geral, às maiores fontes de incerteza. Enquanto a 
estimativa de alguns fluxos pode ser realizada por diversos métodos, como o fluxo de base, outros, como a contribuição de fluxo lateral entre aqüíferos, são em geral estimados pelo resultado de balanços hídricos ou por imposição de condições de contorno nos modelos matemáticos. Durante o modelo de calibração, estes balanços hídricos, com as estimativas iniciais, são comumente alterados pelos dados calculados do modelo.

iii. Definindo o sistema de fluxo: o sistema hidroestratigráfico representa o cerne do modelo conceitual. Assim, deve ser estimado através dele, o movimento de água subterrânea com base em informações hidrológicas como: precipitação, evapotranspiração, drenagem superficial (escoamento em rios) e runoff (escoamento total, incluindo as partes sobre o terreno e internamente ao mesmo), bem como, pelos valores de carga hidráulica para estabelecer o sistema geral do nível d'água. Tal sistema permite estimar as direções do fluxo subterrâneo. Uma forma usual muito utilizada para diminuir a incerteza sobre o sistema de fluxo definido é a de utilizar análise química da água. Entre os métodos utilizados para inferir direção de fluxo (SWENSON, 1968) e mensurá-lo (KRABBENHOFT et al., 1990) estão os que utilizam medidas de concentração de íons $\left(\mathrm{Ca}^{+2}, \mathrm{Mg}^{+2}, \mathrm{Na}^{+}, \mathrm{SO}_{4}^{-2}, \mathrm{HCO}_{3}^{-} \mathrm{e} \mathrm{Cl}^{-}\right)$, de temperatura da água e de seu $\mathrm{pH}$.

\subsubsection{Erros no desenvolvimento do modelo numérico}

Na sua grande maioria, os modelos matemáticos utilizados na simulação e análise de sistemas de água subterrânea são resolvidos por aproximações que utilizam os métodos numéricos de diferenças finitas (MDF) e elementos finitos (MEF). Pode-se, portanto, identificar os erros associados ao modelo numérico como decorrentes da solução numérica das equações diferenciais parciais (EDP), que representam o movimento de fluxo no meio subterrâneo. Uma descrição sucinta dessas equações é posta a seguir.

Considerando-se meios heterogêneos e anisotrópicos, compostos por camada semiconfinante, bem como, admitidas fontes (como poços), o fluxo é expresso para regime transiente, como: 


$$
\frac{\partial}{\partial x}\left(T_{x} \frac{\partial h}{\partial x}\right)+\frac{\partial}{\partial y}\left(T_{y} \frac{\partial h}{\partial y}\right)=S \frac{\partial h}{\partial t}-R+L \quad ; \quad L=-K_{z}^{\prime} \frac{h_{S}-h}{b^{\prime}}
$$

A expressão (10) representa o fluxo geral em aqüíferos semiconfinados, no qual $h[\mathrm{~L}]$ é a sua carga hidráulica; $T_{x}$ e $T_{y}\left[\mathrm{~L}^{2} / \mathrm{T}\right]$ são as componentes do tensor de transmissividade; $S[-]$ é o coeficiente de armazenamento; $R[L / T]$ é o termo de fonte, podendo representar ganhos devido à recarga ou perdas devido a poços; $L[\mathrm{~L} / \mathrm{T}]$ é a drenança através da camada confinante (recarga indireta); $K_{z}^{\prime}[\mathrm{L} / \mathrm{T}]$ e $b{ }^{\prime}$ [L] são a condutividade hidráulica vertical e a espessura da camada confinante, respectivamente, e $h_{s}[\mathrm{~L}]$ é a carga no aqüífero sobre a camada confinante. A referida expressão é também reconhecida por representar modelos quase tridimensionais, por estabelecer, além do fluxo horizontal, o fluxo entre camadas (ANDERSON e WOESSNER, 1992).

Para aqüíferos não-confinados, entretanto, a expressão (10), deve ter os seguintes termos substituídos: $T_{x}=K_{x} h$ e $T_{y}=K_{y} h$, ainda, pela utilização das hipóteses de Dupuit (1863), e da eliminação do termo de drenança L. A Relação 10 é então reescrita como:

$$
\frac{\partial}{\partial x}\left(K_{x} h \frac{\partial h}{\partial x}\right)+\frac{\partial}{\partial y}\left(K_{y} h \frac{\partial h}{\partial y}\right)=S_{y} \frac{\partial h}{\partial t}-R
$$

na qual, $K_{x}$ e $K_{y}$ [L/T] são as componentes do tensor de condutividade hidráulica e $S_{y}[-]$ é definido como o rendimento específico. $R[\mathrm{~L} / \mathrm{T}]$ pode representar, também, a recarga direta. A expressão (11) é conhecida como equação de Boussinesq (BEAR, 1979).

Considerando-se a situação mais geral, de modelos tri-dimensionais, em meios heterogêneos e anisotrópicos o fluxo é expresso por:

$$
\frac{\partial}{\partial x}\left(K_{x} \frac{\partial h}{\partial x}\right)+\frac{\partial}{\partial y}\left(K_{y} \frac{\partial h}{\partial y}\right)+\frac{\partial}{\partial z}\left(K_{z} \frac{\partial h}{\partial z}\right)=S_{S} \frac{\partial h}{\partial t}-R^{*}
$$


no qual, $S_{S}[1 / \mathrm{L}]$ e $R^{*}[1 / \mathrm{T}]$ são o coeficiente de armazenamento específico e o termo de fonte, respectivamente.

$\mathrm{Na}$ maioria das vezes, os erros decorrentes das soluções numéricas das EDPs apresentam-se atuando conjuntamente, o que, em geral, dificulta a identificação dos mesmos. Entretanto, para avaliar a qualidade da solução numérica torna-se importante identificar as principais fontes de erro relacionadas ao modelo numérico (FORTUNA, 2000). É possível classificá-las como segue.

\subsubsection{Erros de modelagem}

Nas representações do fluxo subterrâneo através de um modelo numérico, estes erros são representados por eventuais simplificações nas EDPs, como supor que coeficientes são constantes e que termos podem ser desprezados. Como exemplo, está a consideração de que $T$ é constante em períodos de tempo, durante a simulação de problemas transientes em aqüíferos livres. Em situações específicas da geometria do aqüífero e de valores elevados de $K, \frac{d h}{d x}$ ou período de tempo, pode-se estabelecer diferenças maiores entre a solução numérica e o comportamento do problema físico (ANDERSON e WOESSNER, 1992).

Os modelos de água subterrânea podem ser caracterizados de diversas formas, principalmente, quanto a sua dimensionalidade (uma, duas ou três dimensões), temporalidade (estacionário ou transiente), uniformidade (isotrópico ou anisotrópico), homogeneidade (homogêneo ou heterogêneo), sistema de confinamento (confinado, livre, semiconfinado ou drenante). Como variadas combinações entre essas características principais são possíveis, quanto mais geral e representativo das condições de campo for o modelo concebido, maiores serão as necessidades por condições auxiliares (contorno e iniciais). Condições iniciais ou de fronteira especificadas incorretamente, por "falta" ou "excesso", freqüentemente fazem com que a solução não seja única ou mesmo fisicamente plausível, representando uma importante componente dos erros de modelagem, daí o necessário cuidado na definição das mesmas. 
Nos modelos de fluxo de água subterrânea, as condições de contorno representam restrições hidrogeológicas definidas matematicamente por três conhecidos tipos de condição:

a) carga especificada (condição de $1^{\circ}$ tipo ou de Dirichlet), para qual as cargas hidráulicas são conhecidas ou atribuídas, $h=h_{0}$, aplicável principalmente para representar a carga em pontos do aqüífero, podendo coincidir com o nível de corpos d'água (rios, lagos , etc) ou poços de monitoramento;

b) fluxo especificado (condição de $2^{\circ}$ tipo ou de Neumann), para qual o fluxo normal, $q_{o}$, através do contorno é conhecido,

$$
q_{o}=-K \frac{\partial h}{\partial x},
$$

(caso unidimensional), aplicável, entre outros, na representação de divisores de água do aqüífero, fluxo lateral entre aqüíferos vizinhos e fluxo de saída do aqüífero (descarga profunda);

c) fluxo dependente de carga, ou carga-dependente (condição de $3^{\circ}$ tipo, Cauchy, Robin ou mista), para a qual o fluxo através do contorno é calculado em função de um valor de carga conhecido. Sua caracterização matemática é dada pela definição da combinação linear das duas condições anteriores.

$$
K \frac{\partial h}{\partial x}+\alpha h=\beta .
$$

Essa expressão representa a situação de fluxo dependente da diferença de cargas entre o aqüífero ( $h$ e sua correspondente vizinhança externa, carga fonte $h_{o}$ ), separadas por uma camada ou interface semipermeável, na qual $\alpha=-K^{\prime} / B^{\prime}$ e $\beta=-h_{o} K^{\prime} / B^{\prime}$, sendo $K^{\prime}$ e $B$, respectivamente, a condutividade hidráulica e espessura da camada semipermeável (BEAR, 1979). Assim, em situações práticas, a expressão (14) é substituída pela expressão equivalente,

$$
q=\frac{\left(h_{o}-h\right)}{\sigma^{\prime}}
$$


na qual, $\sigma^{\prime}=B^{\prime} / K^{\prime}$ representa a resistência hidráulica da camada. Esse fluxo é também conhecido como leakage e essa condição é utilizada na prática para representar diversas situações, como o fluxo entre aqüíferos drenantes separados por camadas semipermeáveis, fluxo de base ao longo de corpos d'água tendo como interface semipermeável o sedimento dos respectivos leitos, drenos e evapotranspiração dependente do nível freático. A Figura 9 esboça algumas aplicações das condições de contorno mencionadas.

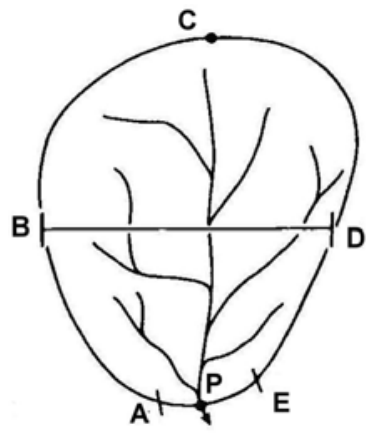

(a)

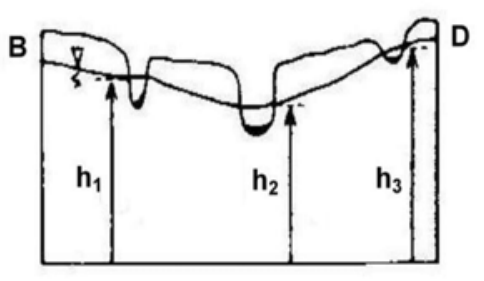

(b)

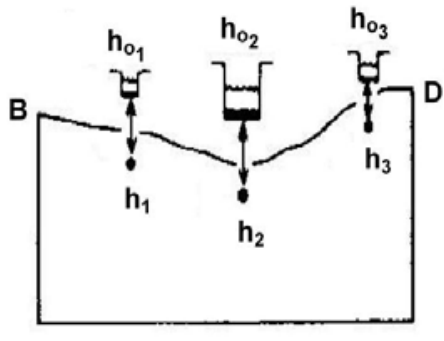

(c)

Figura 9 - Condições de contorno no aqüífero, adaptado de ANDERSON e WOESSNER (1992)

(a) - A bacia, delimitada pelo perímetro ABCDE, coincidente com o divisor de águas do aqüífero, ao longo do qual, é especificada a condição de contorno de fluxo nulo. No trecho $A E$ é aplicada a condição de fluxo especificado de saída do aqüífero, e em $\mathrm{P}$ pode ser utilizada a condição de carga especificada no rio.

(b) - Aplicação da condição de carga especificada coincidente com o nível dos rios (seção transversal BD da bacia).

(c) - Aplicação da condição de fluxo dependente da carga para representar o efeito leakage nos rios parcialmente penetrantes (seção transversal BD da bacia).

Todas as opções mencionadas para representar condições de contorno podem ser utilizadas também no interior do domínio para simular fontes ou contornos internos (por exemplo, para simular rios, lagos drenos etc, localizados no interior da malha). Segundo ANDERSON e WOESSNER (1992), a distinção entre as condições de contorno e condições internas, para o caso de cargas 
especificadas, é por vezes tênue, como exemplo, o caso de um rio que atravessa o domínio do problema, simulado por uma condição interna totalmente penetrante, significa, na prática, o estabelecimento de dois domínios que podem ser tratados de forma independente pela condição de contorno do $3^{\circ}$ tipo. Entretanto, caso o rio não esteja em condição inteiramente penetrante, ele será mais apropriadamente simulado no interior do domínio como condição interna atribuída como fonte.

\subsection{Características e incertezas na aplicações das condições de contorno}

Após o estabelecimento do modelo conceitual, as condições de contorno a serem especificadas possuem incerteza não apenas quanto a sua intensidade ou valor, mas, freqüentemente, também quanto a sua distribuição espacial. Devido a esse fato, é preferível utilizar predominantemente as condições de contorno físicas visíveis, como extensão de corpos d'água, afloramentos impermeáveis etc. Esses contornos físicos são mais facilmente especificados espacialmente e as correspondentes inferências quantitativas feitas pelas condições de contorno hidráulicas menos sujeitas a erros. As demais condições de contorno, incluindo as que se relacionam a aspectos físicos, como os fluxos do sistema sinalizados pela topografia, são características mais transitórias que podem variar localmente ou mesmo desaparecer completamente com a variação de condições hidrológicas, embora os divisores de aqüíferos regionais sejam, em geral, mais permanentes que os demais contornos hidráulicos (ZHENG et al., 1988).

Ressalvas têm sido encontradas, na simulação de rios em modelos regionais utilizando a condição de contorno de $1^{\circ}$ tipo, como no trabalho de JORGENSEN (1989), no qual, tal procedimento levou a erros significativos na determinação de cargas hidráulicas nas zonas vizinhas aos rios.

Apesar de um modelo conceitual, ocasionalmente, poder ser inteiramente especificado por condições de $2^{\circ}$ tipo (modelo representado pela Figura 9 (a), ignorando-se a condição de contorno em "P"), esse procedimento inviabiliza a unicidade na solução das equações diferenciais governantes. De forma mais direta, significa que a solução do problema estacionário fica sem uma referência 
de elevação para o cálculo dos valores de carga hidráulica, sendo necessário pelo menos um ponto de contorno com a condição de carga especificada.

Para a simulação de corpos d'água parcialmente penetrantes pode-se usar a condição de contorno de carga-dependente, leakage (Relação 15). Esta opção, entretanto, requer a atribuição da característica hidráulica de cada trecho ao longo do corpo d'água, além da especificação dos respectivos valores de carga hidráulica da fonte, para cada ponto da malha. Nos casos em que se podem utilizar ambas as condições de contorno, apesar da aparente vantagem da condição de $1^{\circ}$ tipo em relação à de $3^{\circ}$ tipo, a melhor escolha só é estabelecida após a calibração do modelo.

\subsection{Aplicação de condições iniciais}

As condições iniciais constituem o segundo grupo de condições auxiliares a serem definidas durante o procedimento de construção de modelos transientes e que, igualmente às condições de contorno, estão associadas a incertezas. As condições iniciais são representadas pela distribuição de carga hidráulica para todo o sistema no inicio da simulação e fornecem um cenário do estado estacionário calibrado do aqüífero, servindo como referência inicial à evolução das simulações transientes. Segundo FRANKE et al. (1987), a relevância da qualidade destes dados calibrados é de que o modelo hidrológico e seus parâmetros estarão consistentes entre si e a resposta do modelo nos primeiros intervalos de tempo refletirá corretamente a propagação do modelo de tensões hidrológicas. Por outro lado, um aspecto a se considerar é quanto ao nível de interação entre as tensões hidrológicas no domínio do aqüífero e as condições de contorno estabelecidas inicialmente e consideradas constantes num período de tempo. Ao longo do período de simulação devem-se verificar as possíveis mudanças no fluxo ou cargas nas seções, tidas como contorno do aqüífero modelado, devido à ação de tensões hidrológicas, como o bombeamento de poços. Essas tensões impostas ao sistema podem causar, p.ex., um deslocamento no divisor de águas do aqüífero efetivamente considerado pelo modelo. Segundo ANDERSON e WOESSNER (1992), nestes casos, a solução 
pode apresentar grandes diferenças se o contorno é fixado na antiga posição do divisor de águas do aqüífero a partir da imposição da condição de fluxo nulo (condição de $2^{\circ}$ tipo). De modo geral, isso vale para os casos nos quais as tensões hidrológicas internas se propagam até os contornos. Uma sugestão apresentada por MARSILY (1986), para avaliar essa influência, é checar as variações das taxas de fluxo através dos contornos com condições de carga especificada, $\left.\frac{\partial q}{\partial t}\right|_{h_{o}}$, e checar as variações temporais de carga nos contornos com condições de fluxo especificado, $\left.\frac{\partial h}{\partial t}\right|_{q_{o}}$. As variações devem indicar valores nulos ou muito baixos ao longo de todo o período simulado, comprovando a manutenção das características gerais do sistema.

\subsubsection{Erros de discretização geométrica e temporal}

A solução numérica não gera soluções contínuas como as analíticas, mas sim valores para pontos determinados. Trata-se, portanto, de uma etapa fundamental na solução numérica de um problema específico, a escolha dos pontos para os quais a solução será obtida, o que é determinado pela discretização do domínio do modelo representado pela malha. O ajuste deficiente entre partes do domínio modelado e a malha adotada impõem dificuldades maiores quando da atribuição de valores, p.ex. fluxo, aos respectivos pontos desse domínio. Nesse processo, é comum a determinação de valores em pontos da malha a partir da interpolação de valores vizinhos, que em geral produz bons resultados. Como exemplo, a Figura 10 ilustra uma malha comumente utilizada no MDF onde a fronteira $F$ não está alinhada às linhas $x=$ cte. e $y=$ cte. do sistema de coordenadas cartesiano; o cálculo da componente de fluxo $q$ normal à $F$ no ponto $P$ exige interpolações tendo como informação valores de pontos adjacentes a $\mathrm{P}$, introduzindo imprecisões que podem diminuir a qualidade da solução numérica (FORTUNA, 2000). 


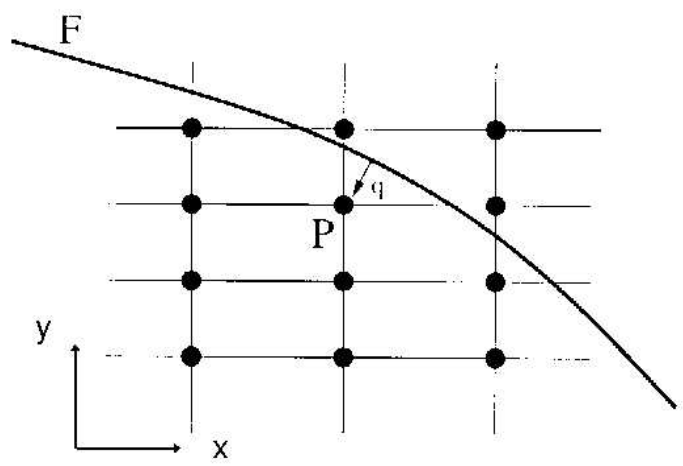

Figura 10 - Fronteira não alinhada ao sistema de coordenadas, adaptado de FORTUNA (2000)

O refinamento da malha é, em geral, o procedimento comumente utilizado para minimizar este problema, com o respectivo aumento do custo computacional da solução numérica. Entretanto, em se tratando de um domínio com contorno bastante irregular, o MEF permite o uso de malhas não-estruturadas estabelecendo um melhor ajuste entre a malha e o domínio. As malhas estruturadas introduzem dificuldades quando a geometria do problema apresenta apêndices que não permitem que o domínio físico seja mapeado em um único bloco. A Figura 11 mostra exemplos dessas malhas que, em uma rápida definição, podem ser descritas por possuírem os vértices, cada qual, com vizinhança local isomorfa - caso de malhas estruturadas. Em duas dimensões corresponde, na maior parte dos casos, a uma grade quadrada deformada por alguma transformação de coordenadas. As malhas não-estruturadas podem apresentar vizinhos locais arbitrariamente variados. Em geral, correspondem a triangulações com vizinhança local não-isomórfica.

A escolha da malha também pode influir decisivamente na qualidade da solução numérica. Um exemplo disto é a utilização de dois pontos muito próximos numa malha onde a distância média entre os pontos é significativamente maior, podendo induzir erros significativos na solução final do problema. Matematicamente isso é interpretado como a inclusão de uma quasesingularidade na matriz (dois pontos com mesma equação), dificultando a solução do sistema de equações. Este efeito é a princípio mais susceptível às malhas não-estruturadas, entretanto, diversas técnicas disponíveis avaliam a qualidade dessas malhas e programas automatizados para geração de malhas possuem, 
internamente em seus códigos, a implementação dessas técnicas com o objetivo de minimizar a ocorrência do exemplo mencionado.

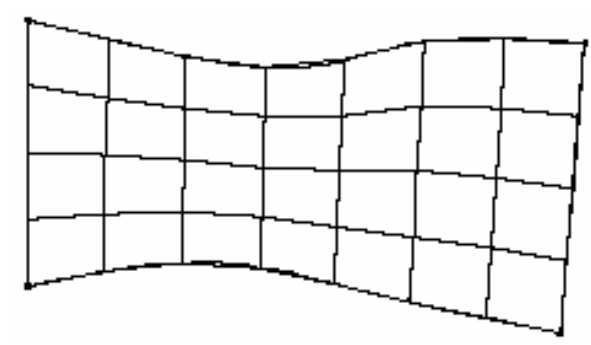

(a)

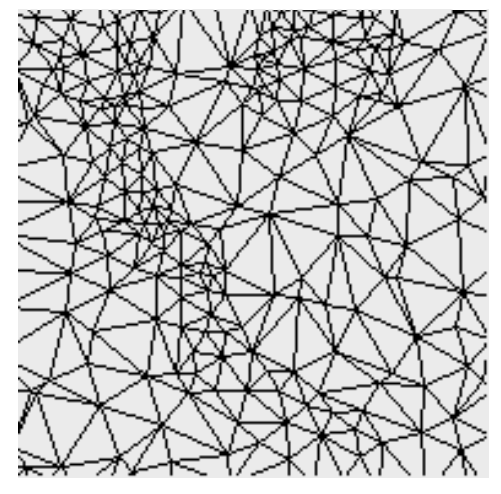

(b)

Figura 11 - Exemplos de malhas bi-dimensionais: (a) estruturada e (b) nãoestruturada

Assim como a construção da malha, a discretização do tempo pode influenciar fortemente a solução em modelos transientes. Esta discretização corresponde à escolha do intervalo de tempo, $(\Delta t)$, que separa os instantes de cada solução numérica para o conjunto total de pontos da malha. Em termos ideais, é desejável o menor espaçamento nodal $(\Delta x)$ e o menor intervalo de tempo $(\Delta t)$ para que a representação numérica se aproxime melhor da representação analítica da equação diferencial governante. Na prática, entretanto, é mais viável a utilização de intervalos de tempo maiores, baseados inicialmente em critérios de estabilidade da solução numérica. A escolha de $\Delta t$ pode também ser influenciada pelas necessidades especificas do código computacional a ser utilizado. Uma sugestão apresentada por MARSILY (1986), aplicável ao MDF, é a de iniciar atribuindo a $\Delta t$ o máximo valor para a formulação explícita (formulação menos estável que a implícita), que para a simulação bi-dimensional de um aqüífero confinado, homogêneo e isotrópico vale:

$$
\frac{T}{S}\left[\frac{\Delta t}{(\Delta x)^{2}}+\frac{\Delta t}{(\Delta y)^{2}}\right] \leq \frac{1}{2},
$$


na qual, $T$ e $S$ são os parâmetros de transmissividade e armazenamento, $\Delta x$ e $\Delta y$ os espaçamentos da malha nas direções ortogonais $x$ e $y$. Outros aspectos da modelagem, como o interesse em determinar a solução logo após o inicio da aplicação de tensões hidrológicas, contribuem para estabelecer o valor de $\Delta t$ nas simulações. Resultados obtidos de simulações transientes que chegam próximas de situações estacionárias podem, em geral, utilizar maiores intervalos de tempo. Tal procedimento decorre da melhor aproximação entre as soluções numérica e analítica verificadas para um maior número de intervalos de tempo de simulação. Apesar dos modelos de fluxo serem pouco susceptíveis a oscilações, em relação a modelos de transporte, a escolha inadequada de $\Delta t$ pode provocar a obtenção de resultados com oscilações que não correspondem à realidade (ANDERSON e WOESSNER, 1992). Assim, a prudência em relação à definição de $\Delta t$ sugere uma investigação a partir dos resultados obtidos da simulação desejada. O maior valor obtido de $\Delta t$, para o qual não gere variações significativas nos resultados, pode ser tomado como o melhor valor.

\subsubsection{Erros na solução numérica}

Os erros referentes à solução numérica estão associados aos processos de discretização numérica, convergência e arredondamento, inerentes às técnicas numéricas de solução. Associada à discretização numérica, estão os erros incorridos no processo de representação das equações diferenciais parciais em equações algébricas que, p.ex., no MDF representa o erro de truncamento das séries de Taylor empregadas na representação dessas equações. Nessa representação, aumentando-se a ordem de discretização - p.ex. de $O(\Delta x)$ para $\mathrm{O}(\Delta x)^{2}$ - reduz-se esses erros, entretanto, o aumento continuado da ordem de discretização não garante a melhoria da qualidade da solução numérica, uma vez que, isso torna a solução numérica mais sujeita a instabilidades a depender do grau de refinamento da discretização geométrica utilizada (FORTUNA, 2000). Os erros de convergência são definidos como a diferença entre a solução fornecida pelos métodos numéricos iterativos e a solução exata das equações algébricas. 
Diminuindo-se a tolerância do critério de convergência, podem-se reduzir esses erros com o aumento do custo computacional no cálculo da solução numérica. Os erros de arredondamento, devido à representação finita dos números pelo computador, têm, contudo, seu efeito minimizado pela utilização de precisão aumentada na representação aritmética desses números, procedimento esse tornado viável, devido às atuais configurações comumente disponíveis de hardware dos computadores.

\subsubsection{Aplicação de elementos de modelagem - aspectos de incerteza}

Como forma de exemplificar aspectos de incerteza dos elementos que compõem os modelos de fluxo de água subterrânea, é considerado o Sistema Aqüífero Guarani (SAG). A seguir, são considerados aspectos de incerteza decorrentes da distribuição das formações geológicas referentes a modelo conceitual, fluxos, e parâmetros hidráulicos.

Uma das principais fontes de incerteza na construção desses modelos corresponde à recarga do aqüífero. No exemplo em questão, a recarga natural ocorre segundo dois mecanismos principais: por meio de infiltração direta das águas de chuva, na área de afloramento, e de forma retardada em parte da área confinada, por infiltração vertical (drenança) ao longo de descontinuidades das rochas do pacote confinante, onde a carga piezométrica favorece os fluxos descendentes. As sub-bacias nessas zonas consideradas de afloramento, contudo, apresentam comumente alguma parcela de condição mista de recarga decorrente de camadas confinantes (CORRÊA, 1995). Tal condição é estabelecida, nessas áreas da porção brasileira do SAG, pela presença intercalada de rochas vulcânicas confinantes, caracterizadas por rochas basálticas fraturadas da Formação Serra Geral sobre o Aqüífero Guarani, este, majoritariamente composto por rochas sedimentares da Formação Botucatu sobre a Formação Pirambóia. Contudo, fora das referidas zonas de afloramento do Aqüífero Guarani encontram-se, freqüentemente, zonas onde o nível da superfície potenciométrica é superior ao topo dos reservatórios sedimentares, invertendo o fluxo descendente sobre o aqüífero. Assim, as rochas vulcânicas da Formação 
Serra Geral funcionam também como reservatórios, além de seu caráter de barreira hidráulica (ROSA FILHO et al., 2003). Considerando-se essas possibilidades de fluxo, tem-se que o comportamento hidráulico do Aqüífero Guarani estabelece incertezas ainda na elaboração do modelo conceitual, devido à distribuição das referidas formações geológicas. A minimização deste problema caminha, portanto, no sentido de se conhecer melhor a conexão hidráulica entre os Aqüíferos Serra Geral e Guarani, estudo realizado principalmente por meio da aplicação de métodos hidroquímicos, isotópicos ou geofísicos (PORTELA FILHO et al., 2002).

Qualquer que seja a ocorrência dessas formações, consideradas pelo modelo, é necessário estabelecer a distribuição dos respectivos parâmetros hidráulicos, p.ex., K, T e S. Na aplicação de modelos no SAG, parte desses dados já está disponível junto a instituições governamentais ou privadas, considerandose o número de trabalhos nele realizados, dada a sua grande importância sócioeconômica. Entretanto, faz-se necessário dados de qualidade assegurada, comumente para fins de calibração do modelo ou estabelecimento de suas condições auxiliares. Assim, uma das formas práticas e usuais para determinação desses parâmetros é através do método Theis-Jacob, que utiliza as curvas de rebaixamento e recuperação obtidas de testes de bombeamento de poços, determinando diretamente os valores de $T$ e $S$ e estimando $K$ pela relação $T=b . K$. Os valores de $T$ e $S$ obtidos por esse método não estão isentos de aproximações grosseiras devido aos passos de manipulação gráfica (PIUCl e DINIZ, 1985). Apesar dessas fontes de erro serem bastante reduzidas quando da utilização de aplicativos, que automatizam a interpretação de testes de bombeamento baseados em métodos como o de Theis-Jacob, persistem ainda os erros decorrentes dos aspectos aproximativos inerentes a esses métodos, como discutido anteriormente neste capítulo. Esses aplicativos são comumente escolhidos e aplicados a partir de sua capacidade, adequação às características gerais do aqüífero e às condições operacionais disponíveis aos testes de bombeamento.

Os dados obtidos de $S$, contudo, são um indicador da ocorrência de formações com características predominantemente confinadas ou livres, auxiliando na definição ou reformulação das unidades hidroestratigráficas e do 
modelo conceitual. Isto é realizado a partir do conjunto de dados de $S$, verificando-se a tendência dos mesmos aos valores típicos de $S_{y}$ ou $S_{s}$.

A melhor característica hidráulica da Formação Botucatu, em relação à Pirambóia, estabelece, a despeito de sua dificuldade, a necessidade de se estimar uma distribuição dos parâmetros hidráulicos ao longo da espessura do Aqüífero Guarani, através destas formações. Um valor médio para esses parâmetros é atribuído pelos modelos bi-dimensionais horizontais, enquanto que para os modelos tri-dimensionais ou bi-dimensionais de perfil, podem ser alocados valores variáveis. Qualquer que seja a opção pela dimensão do modelo aplicado, a simulação das características hidráulicas, dada a presença dessas formações, configura fontes de incerteza. Para uma caracterização mais adequada, são buscados dados das características hidráulicas e estratigráficas da área de estudo, entretanto, quando muito localizados, em comparação à área de estudo, mostram-se inadequados à simulação do Aqüífero (VIVES et al., 2001), sendo um exemplo do processo conhecido como scaling effect.

Devido às diversas fontes de erro mencionadas, que interferem nos resultados do modelo numérico, faz-se necessária a indicação de que este é capaz de reproduzir medidas de campo, p.ex., de carga e vazão. Tal procedimento é realizado duante a calibração do modelo, feito pela variação dos seus parâmetros de ajuste, como parâmetros hidráulicos, recarga e condições de contorno. Finalmente, segundo ANDERSON e WOESSNER (1992), os resultados da calibração devem ser avaliados qualitativamente e quantitativamente, mas, mesmo na avaliação quantitativa, o juízo do quão bom é o ajuste entre modelo e realidade é subjetivo. Em seguida, é importante a nálise de sensibilidade como forma de quantificar a incerteza no modelo calibrado, sobretudo em modelos não hipotéticos, causada pela incerteza das estimativas dos parâmetros do aqüifero e condições de contorno. Apesar de intimamente relacionadas às incertezas, as técnicas de calibração e análise de sensibilidade são um capítulo à parte e estão fora do escopo deste texto. 


\subsection{CONTRIBUIÇÃO DA REVISÃO AO MODELO PROPOSTO}

Considerando-se o propósito de determinar a recarga e o sistema de fluxo do Aqüífero Guarani, bem como, considerando-se as características e dimensão da área de estudo, conclui-se que a técnica de estimativa de recarga por meio de modelagem numérica de aqüífero é das mais adequadas entre as apresentadas. Contudo, a complexidade hidrogeológica da área de estudo pode fazer com que o modelo não consiga reproduzir satisfatoriamente comportamentos localizados do aqüífero, sobretudo nas regiões de transição entre aqüifero livre e confinado (ou semiconfinado), representadas pelas intercalações de arenitos e basaltos.

Apesar do levantamento sistemático de dados, a possível implementação de um modelo tri-dimensional, ainda que em apenas algumas regiões da área de estudo, requereria dados hidráulicos (como drenança e condutividade vertical), vazões de base ao longo da hidrografia e dados estratigráficos - como forma de assegurar a interação local rio-aqüífero - que não são estimáveis ou disponíveis nem em quantidade, nem em qualidade, nem em distribuição espacial suficientes, introduzindo incertezas no valor e distribuição destes parâmetros do aqüifero. Assim, um modelo bi-dimensional apresenta-se como uma solução mais adequada à realidade de dados e características do aqüífero.

As incertezas de diversas origens, descritas anteriormente, e que influenciam as predições do modelo, freqüentemente não podem ser quantificadas individualmente de modo satisfatório. Contudo, as fontes de incerteza descritas, sobretudo as de origem experimental, são uma refêrencia à seleção de dados de campo e definição do modelo conceitual. Assim, faz-se necessário avaliar o efeito das incertezas sobre o modelo, por meio da análise de sensibilidade após sua calibração. 


\section{3 ÁREA DE ESTUDO}

A área objeto de estudo é delimitada pelo conjunto das duas bacias contíguas dos rios Jacaré-Guaçu e Jacaré-Pepira (sistema Jacaré), abrangendo importantes centros urbanos, bem como, diversificadas atividades agro-pecuária e industrial. A região perfaz uma área de drenagem de $6.748 \mathrm{~km}^{2}$, com $140 \mathrm{~km}$ de comprimento, $70 \mathrm{~km}$ de largura máxima e 447,5 km de perímetro, localiza-se na porção central do Estado de São Paulo, entre os paralelos $21^{\circ} 37^{\prime}$ e $22^{\circ} 31^{\prime}$ de latitude sul e os meridianos $47^{\circ} 43^{\prime}$ e $49^{\circ} 02^{\prime}$ de longitude oeste. Pertencentes à Bacia Hidrográfica Tietê/Jacaré, os rios Jacaré-Guaçu e Jacaré-Pepira deságuam na região do curso médio do Rio Tietê (Figura 12). A área de estudo é atualmente classificada no Estado de São Paulo como pertencente à Unidade de Gerenciamento de Recursos Hídricos 13 do sistema de bacias Tietê-Jacaré (UGRHI-TJ). As Bacias Hidrográficas do Jacaré-Guaçu $\left(4.161 \mathrm{~km}^{2}\right.$ ) e Jacaré-

Pepira (2.587 $\mathrm{km}^{2}$ ) apresentam características semelhantes, tanto em ocupação e desenvolvimento como em sua geologia, pedologia, climatologia, hidrologia e hidrogeologia (DAEE, 1974; CORRÊA, 1995). 


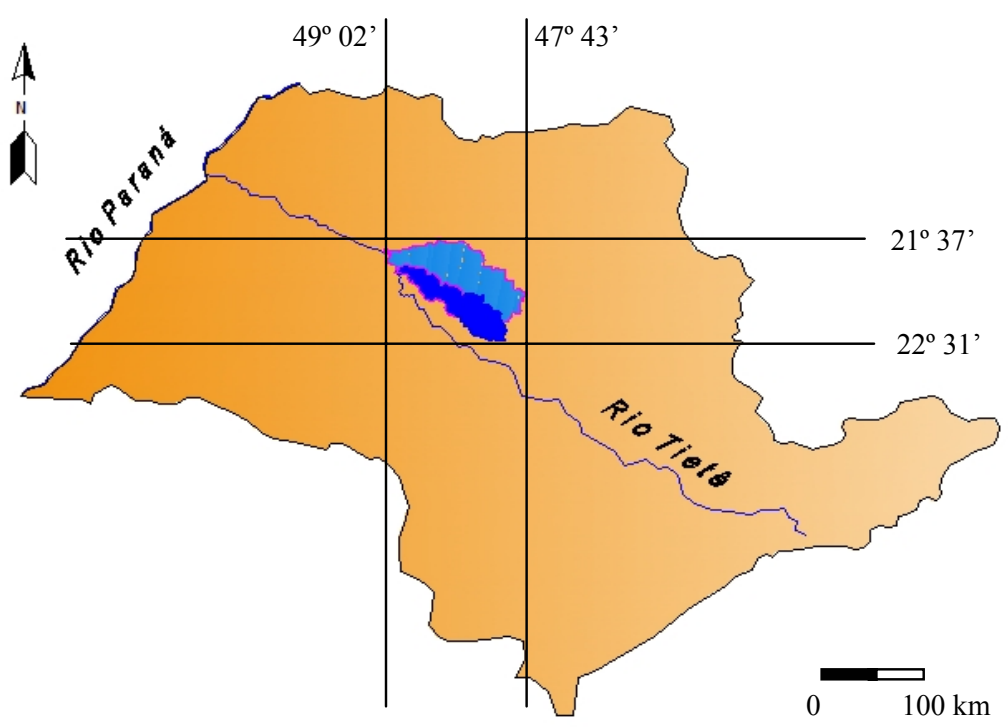

Figura 12 - Localização do sistema Jacaré formado pelas bacias contíguas do Jacaré-Guaçu (mais ao norte) e do Jacaré-Pepira (mais ao sul), em relação ao Estado de São Paulo

\subsection{GEOLOGIA}

A litoestratigrafia do SAG inclui rochas dos períodos Triássico, Jurássico e Cretáceo, que dão ao sistema sua maior identidade. Os arenitos do período Jurássico, de origem eólica e maior produtividade hidráulica, constituem-se nos melhores reservatórios das bacias do sistema Jacaré, enquanto os do Triássico, de origem flúvio-lacustre/eólico possuem, em geral, maior teor de argila em sua parte inferior, que diminui relativamente sua eficiência hidráulica. A estrutura abaixo dos arenitos do Juarássico e Triássico - que compõem o Aqüífero Guarani - compreende uma formação de baixa permeabilidade e caracteriza-se como um aquitardo do período Permo-Triássico. Acima, o Aqüífero Guarani é recoberto por sucessivas camadas de derrame basáltico da Formação Serra Geral (Cretáceo), provenientes de atividade vulcânica, que formam rochas consolidadas descontínuas, caracterizadas em parte como aquitardo e em parte como aqüífero, que por sua vez é recoberto por arenitos da Formação Bauru (Cretáceo Superior), caracterizados como aqüífero superior da seqüência. 
As unidades geológicas que afloram na área das bacias hidrográficas do sistema Jacaré são os sedimentos clásticos, predominantemente arenosos, as rochas ígneas basálticas do Grupo São Bento (Mesozóico da Bacia do Paraná), as rochas sedimentares do Grupo Bauru, os sedimentos pertencentes à Formação Itaqueri e depósitos correlatos (das serras de São Carlos), de idade cretácea a cenozóica, e pelos sedimentos aluvionares associados à rede de drenagem. A sucessão em que ocorrem essas formações na área de estudo e a respectiva caracterização das rochas estão inclusas na descrição geral da estratigrafia da Bacia do Paraná, acrescida das ocorrências de rochas mais recentes (Quaternário e Terciário) específicas da área de estudo (Tabela 7).

O Grupo São Bento compõe a maioria das formações envolvidas na área de estudo: Formações Serra Geral, Botucatu e Pirambóia (Figura 13). Os sedimentos arenosos da Formação Pirambóia afloram na área, em duas manchas principais, ao longo das sub-bacias do Médio Jacaré-Guaçu e Médio Jacaré-Pepira. Manchas menores são observadas a leste e sudeste, geralmente junto aos vales das drenagens, onde já foram erodidas as unidades superiores (SCHNEIDER et al., 1974; SOARES, 1973, apud MATOS, 1987). Esta Formação é composta por uma sucessão de camadas arenosas de coloração avermelhada a esbranquiçada. Segundo SOARES (1975), a espessura tem valor máximo em torno de $350 \mathrm{~m}$ na Bacia do Tietê, e dados de perfuração de poços (DAEE, 1998) obtiveram espessura máxima de 146 m em São Carlos.

Os arenitos da Formação Botucatu afloram em uma expressiva área nas bacias dos rios Jacaré-Guaçu e Jacaré-Pepira, que se estende desde a região de Itirapina, a leste, até as proximidades da Barragem de lbitinga, a oeste, onde aqueles rios se afunilam para desaguar no Rio Tietê (reservatório de lbitinga). Dali para o oeste, os arenitos encontram-se recobertos pela capa representada pelos basaltos da Formação Serra Geral e pelos sedimentos do Grupo Bauru. A Formação Botucatu é constituída por arenitos avermelhados com estratificação cruzada tangencial de médio a grande porte, de granulação fina a média, com grãos bem selecionados e apresentando alta esfericidade (IPT, 2003). Segundo sondagens, a espessura no Estado provavelmente excede os $200 \mathrm{~m}$ e dados de perfuração de poços na área de estudo (DAEE, 1998) indicaram espessura máxima de 192 m em lbaté. 
Tabela 7 - Coluna litoestratigráfica de parte da Bacia do Paraná (IPT, 1981; IPT, 2003)

\begin{tabular}{|c|c|c|c|c|c|}
\hline \multicolumn{2}{|c|}{$\begin{array}{l}\text { Era / } \\
\text { Sist. }\end{array}$} & Grupo & Formação & \multicolumn{2}{|l|}{ Tipos de Rochas (Litologia) } \\
\hline \multirow{2}{*}{$\begin{array}{l}\text { O } \\
\text { ON } \\
\text { Oे } \\
\text { U. }\end{array}$} & \multirow{2}{*}{ 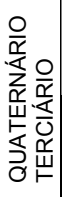 } & & & \multicolumn{2}{|c|}{$\begin{array}{l}\text { Sedimentos Aluvionares (Qa): aluviões em geral, incluindo depósitos de terraço. } \\
\text { Cobertura da Serra de São Carlos e similares (TQi): arenitos conglomeráticos. }\end{array}$} \\
\hline & & & Itaqueri (KTi) & \multicolumn{2}{|c|}{$\begin{array}{l}\text { Predominantemente arenitos com cimento argiloso com lentes alongadas de } \\
\text { folhelhos e com conglomerados limíticos. }\end{array}$} \\
\hline \multirow{7}{*}{ 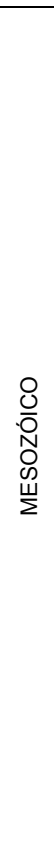 } & \multirow{5}{*}{ 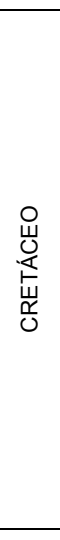 } & \multirow{4}{*}{ BAURU } & Marília (Km) & \multicolumn{2}{|c|}{$\begin{array}{l}\text { Arenitos de granulação fina e grossa, compreendendo bancos maciços com } \\
\text { tênues estratificações cruzadas de médio porte. Subordinadamente ocorrem } \\
\text { lentes de siltitos, argilitos e arenitos muito finos. Presença comum de nódulos } \\
\text { carbonáticos. }\end{array}$} \\
\hline & & & $\begin{array}{l}\text { Adamantina } \\
(\mathrm{Ka})\end{array}$ & \multicolumn{2}{|c|}{$\begin{array}{l}\text { Arenitos finos e muito finos, podendo apresentar cimentação e nódulos } \\
\text { carbonáticos com lentes de siltitos arenosos e argilitos ocorrendo em bancos } \\
\text { maciços, estratificação plano-paralela e cruzada de pequeno a médio porte. }\end{array}$} \\
\hline & & & $\begin{array}{l}\text { Santo } \\
\text { Anastácio } \\
\text { (Ksa) }\end{array}$ & \multicolumn{2}{|c|}{$\begin{array}{l}\text { Arenitos muito finos e médios, mal selecionados, subordinadamente de caráter } \\
\text { aroosiano, geralmente maciços, apresentando localmente cimento e nódulos } \\
\text { carbonáticos. }\end{array}$} \\
\hline & & & Caiuá (Kc) & \multicolumn{2}{|c|}{$\begin{array}{l}\text { Arenitos finos a médios, com grãos bem arredondados, com coloração arroxeada } \\
\text { típica, apresentando abundantes estratificações cruzadas de grande e médic } \\
\text { porte. Localmente ocorrem cimento e nódulos carbonáticos. }\end{array}$} \\
\hline & & & $\begin{array}{l}\text { Serra Geral } \\
\quad(J K s g)\end{array}$ & \multicolumn{2}{|c|}{$\begin{array}{l}\text { Rochas vulcânicas toleíticas dispostas em derrames basálticos, com coloração } \\
\text { cinza a negra, textura afanítica, com intercalações de arenitos intertrapeanos, } \\
\text { finos a médios, apresentando estratificação cruzada tangencial. Ocorrem } \\
\text { esparsos níveis vitrofíricos não individualizados. }\end{array}$} \\
\hline & 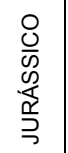 & $\begin{array}{l}\text { SÃO } \\
\text { BENTO }\end{array}$ & $\begin{array}{l}\text { Botucatu } \\
\text { (JKb) }\end{array}$ & \multicolumn{2}{|c|}{$\begin{array}{l}\text { Arenitos eólicos avermelhados de granulação fina a média, com estratificações } \\
\text { cruzadas de médio a grande porte. Ocorrem restritamente depósitos fluviais de } \\
\text { natureza areno-conglomerática e camadas localizadas de siltitos e argilitos } \\
\text { lacustres. }\end{array}$} \\
\hline & 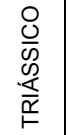 & & $\begin{array}{l}\text { Pirambóia } \\
\text { (TJp) }\end{array}$ & \multicolumn{2}{|c|}{$\begin{array}{l}\text { Depósitos de arenitos finos a médios, avermelhados, síltico-argilosos, com } \\
\text { estratificação cruzada ou plano-paralela, com níveis de folhelhos e arenitos } \\
\text { argilosos variegados e raras intercalações de natureza areno-argilosa. }\end{array}$} \\
\hline \multirow{4}{*}{ 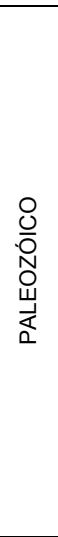 } & \multirow{4}{*}{ 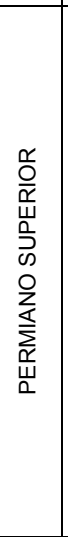 } & \multirow{4}{*}{$\begin{array}{l}\text { PASSA } \\
\text { DOIS }\end{array}$} & $\begin{array}{c}\text { Rio do } \\
\text { Rasto (Prr) }\end{array}$ & $\begin{array}{l}\text { Depósitos de planícies costeiras compreendendo } \\
\text { arenitos muito finos a médios, esverdeados a } \\
\text { avermelhados e, subordinadamente, argilitos e siltitos } \\
\text { avermelhados. }\end{array}$ & \multirow{3}{*}{$\begin{array}{l}\text { Formação } \\
\text { (Pc): Corumbata } \\
\text { possivelmente marinhos } \\
\text { de planícies de maré } \\
\text { incluindo argilitos } \\
\text { folhelhos e siltitos cinza } \\
\text { arroxeados r ou } \\
\text { avermelhados, com } \\
\text { intercalações de bandas } \\
\text { carbonáticas, silexitos } \\
\text { camadas de arenitos } \\
\text { finos. }\end{array}$} \\
\hline & & & Teresina $(\mathrm{Pt})$ & $\begin{array}{l}\text { Depósitos possivelmente marinhos prodeltáicos, } \\
\text { compreendendo folhelhos e argilitos cinza escuros a } \\
\text { esverdeados ou avermelhados, finamente laminados, } \\
\text { em alternância com siltitos e arenitos muito finos, } \\
\text { presença de restritas lentes de calcários oolíticos e } \\
\text { sílex. }\end{array}$ & \\
\hline & & & $\begin{array}{l}\text { Serra Alta } \\
\text { (Psa) }\end{array}$ & $\begin{array}{l}\text { Depósitos essencialmente marinhos incluindo siltitos, } \\
\text { folhelhos e argilitos cinza escuros a pretos, com } \\
\text { laminação plano-paralela. }\end{array}$ & \\
\hline & & & Irati $(\mathrm{Pi})$ & \multicolumn{2}{|c|}{$\begin{array}{l}\text { Siltitos, argilitos e folhelhos sílticos de cor cinza clara a escura, folhelhos } \\
\text { pirobetuminosos, localmente em alternância rítmica com calcários creme } \\
\text { silicificados e restritos níveis conglomeráticos. }\end{array}$} \\
\hline
\end{tabular}

O conjunto das Formações Botucatu e Pirambóia encontra-se distribuído em toda a área de estudo, na maior parte confinado pela Formação Serra Geral. As rochas eruptivas da Formação Serra Geral constituem um conjunto de derrames de basaltos toleíticos de espessura individual bastante variável, na área de estudo variando desde poucos metros a 350 m (DAEE, 1998); os derrames são constituídos por rochas de coloração cinza escura a negra, nos mais espessos a 
zona central é maciça, microcristalina e apresenta-se fraturada por juntas subverticais de contração (disjunção colunar), possuindo na base e topo uma distribuição de basalto vesicular com diaclasamento predominantemente horizontal (GIAMPÁ e SOUZA, 1982) (Figura 14).

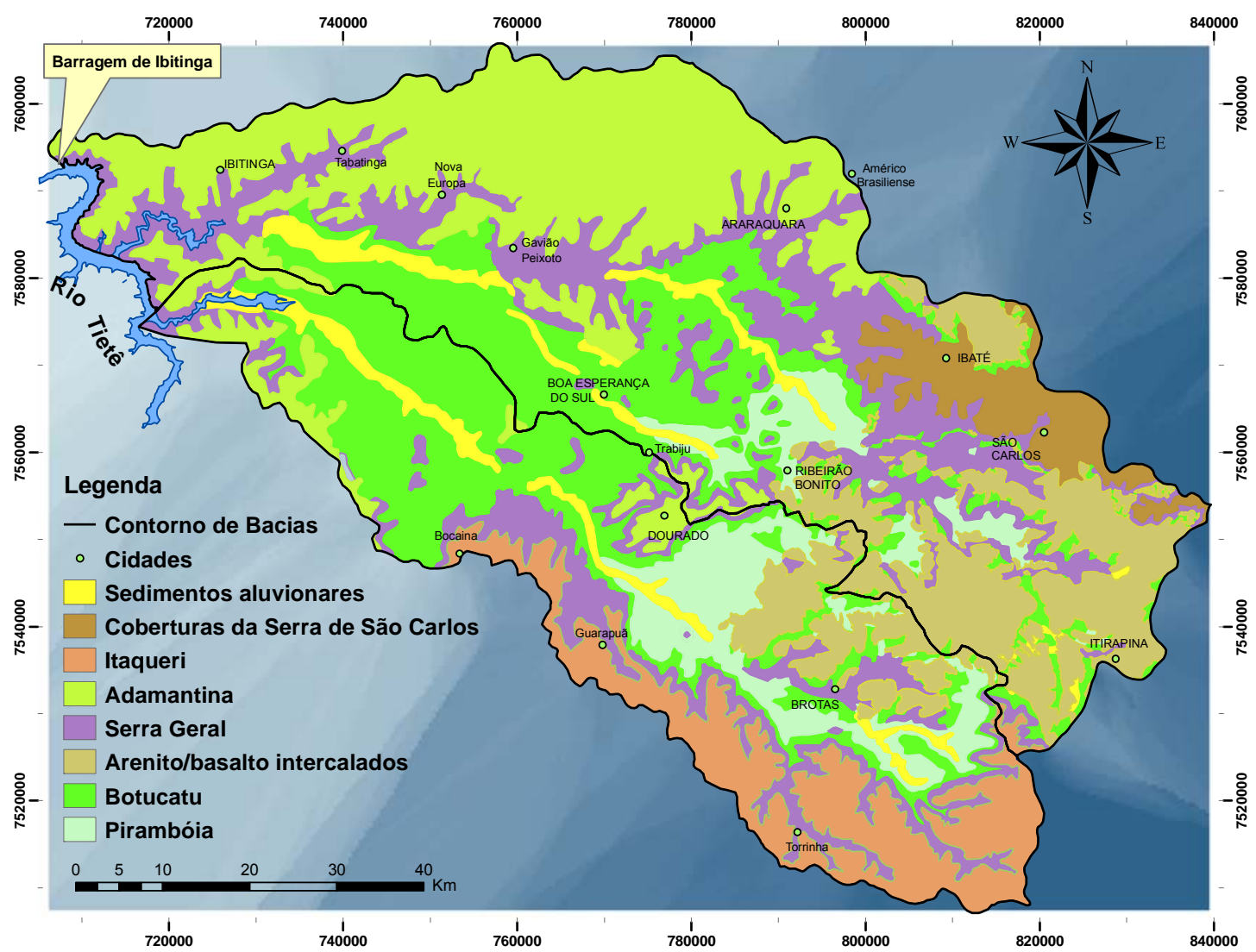

Figura 13 - Mapa geológico da área de estudo (fontes: mapas digitalizados IPT 2003; CORRÊA, 1995)

Nos derrames intercalam-se arenitos com as mesmas características dos arenitos da Formação Botucatu, a maioria com estrutura típica de dunas e outros indicando deposição subaquosa (IPT, 2003). Ocorrência significativa de arenitos intercalados por derrames é identificada por ALMEIDA e BARBOSA (1953), na parte leste da área de estudo, denominada de arenitos intercalares. Esta ocorrência foi mapeada e estudada por CORREAA (1995), sendo considerada estruturas integrantes das Formações Botucatu e Pirambóia, e aqui denominada de arenito/basalto intercalados. Regiões com presença de arenitos intercalados, indicadas por CORREAA (1995), coincidentes com regiões de afloramento do Aqüífero Guarani (Formações Botucatu e Pirambóia), indicadas por IPT (2003), 
foram delimitadas por determinarem uma característica diferenciada destas formações (Figura 13).

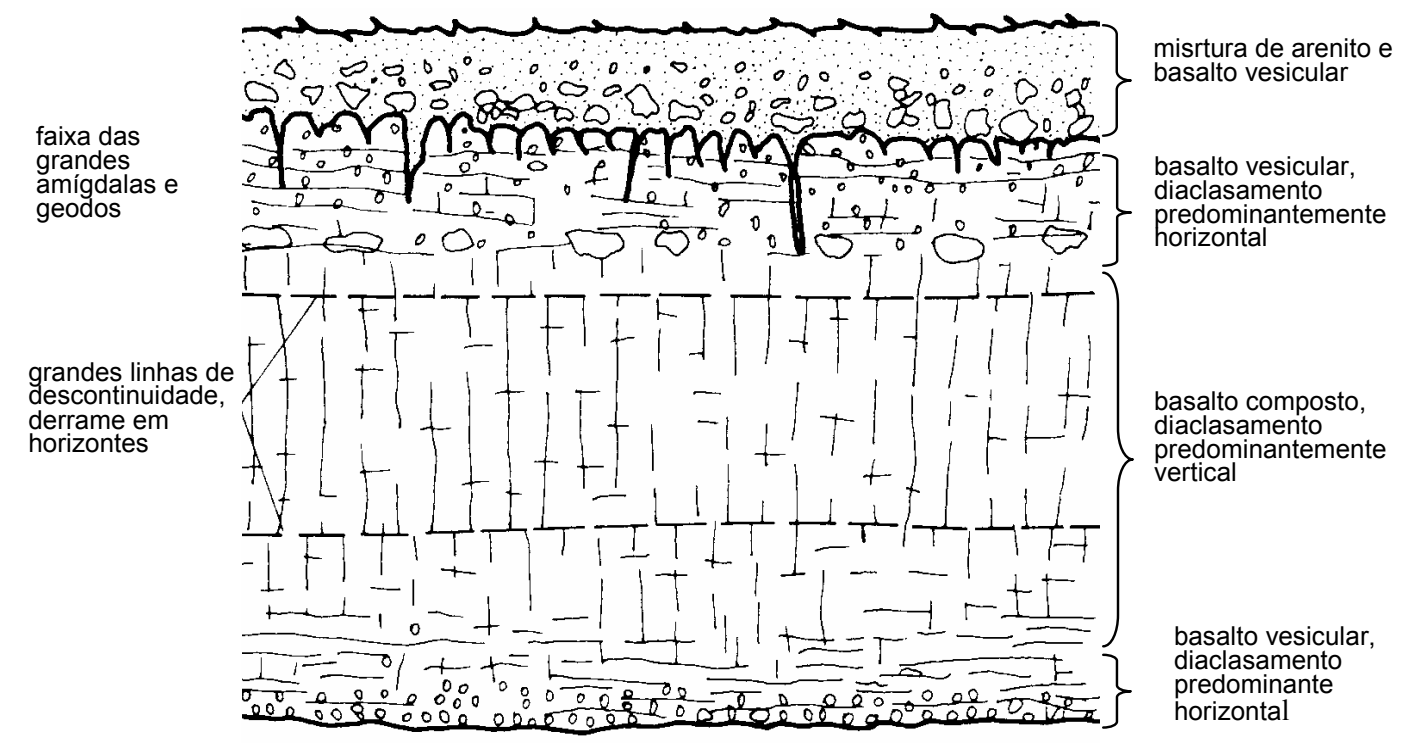

Figura 14 - Seções de derrames basálticos da Formação Serra Geral (GIAMPÁ e SOUZA, 1982)

Entre as unidades sedimentares existentes acima dos derrames basálticos da Formação Serra Geral, integrantes do Grupo Bauru, a Formação Adamantina é a unidade geológica que ocupa uma das maiores áreas de exposição na Bacia do Jacaré estendendo-se desde as proximidades da Barragem de Ibitinga, de onde segue para leste-nordeste, até a região de Araraquara. Em geral, os sedimentos desta Formação apresentam espessura preservada e bastante regular de aproximadamente $100 \mathrm{~m}$, obtida de poços perfurados para água subterrânea no Estado de São Paulo (FERNANDES, 1998), sendo possivelmente menor na área de estudo, por tratar-se de área de borda das formações do Grupo Bauru (IPT, 2003).

Entre os sedimentos pertencentes ao Cenozóico, encontra-se a Formação Itaqueri, já considerada pertencente à seqüência do Grupo Bauru (SOARES et al., 1980) e também como pós-Bauru (COTTAS e BARCELOS, 1981; PONÇANO et al., 1982). A Formação é admitida com idade do Cretáceo ao Terciário (IPT, 1993; MELO, 1995). Ocorre na porção sudeste da área de estudo, numa mancha que se estende pelas serras de Itaqueri e de São Pedro, nas cabeceiras do Rio JacaréPepira. Constitui-se de um pacote de até 120 metros de espessura, de camadas 
alternadas de arenitos com cimento argiloso, folhelhos e conglomerados, estes situados tanto na base quanto no interior do pacote. Os arenitos são de granulação variada, podem ser argilosos e apresentar intensa silicificação (IPT, 1993).

As Coberturas da Serra de São Carlos são depósitos observados na região de São Carlos, ocupando o topo do divisor de águas da parte nordeste da Bacia Hidrográfica do Jacaré-Guaçu, estendendo-se desde a região de São Carlos até a região de lbaté. Trata-se de arenitos conglomeráticos provenientes das serras vizinhas, cuja deposição é sincrônica da escavação da Depressão Periférica, em regime de transporte curto e violento, sob um agente de grande competência e com regime intermitente que permitiu a deposição contemporânea de seixos e argilas (CHRISTOFOLETTI e QUEIROZ NETO, 1966 apud IPT, 1981). Existem registros estratigráficos de ausência da Formação Serra Geral entre os sedimentos da Serra de São Carlos e a Formação Botucatu (PERRONI, 2005).

Os depósitos quaternários se constituem essencialmente de sedimentos aluvionares, cuja distribuição é governada pelos grandes cursos d'água e pela evolução do relevo. $\mathrm{Na}$ área de estudo encontram-se aluvionares mais expressivos nos vales dos rios Jacaré-Guaçu e Jacaré-Pepira. De resto, sedimentos aluvionares existem junto à grande maioria dos cursos d'água da área, mas em dimensões não representáveis na escala adotada (1:250.000).

\subsection{HIDROLOGIA}

A confluência dos rios Jacaré-Guaçu e Jacaré-Pepira determina os exutórios das respectivas bacias hidrográficas, próximos à Barragem de Ibitinga, localizada na calha do Rio Tietê, a aproximadamente $410 \mathrm{~m}$ de altitude. O exutório corresponde ao final do escoamento de uma drenagem total de $3.170 \mathrm{~km}$, que tem suas maiores cotas nas nascentes a aproximadamente $900 \mathrm{~m}$ de altitude e que possui declividade média de $1,1 \%$.

Neste trabalho, os exutórios de ambas as bacias foram considerados em suas posições naturais (calha do Rio Tietê) (Figura 15), e não nos limites do reservatório criado pelo represamento das águas dos respectivos rios, como em 
IPT (2003) (Figura 16). Este procedimento gerou uma área, para as duas bacias, $398 \mathrm{~km}^{2}$ superior a obtida pelo procedimento adotado em IPT (2003).

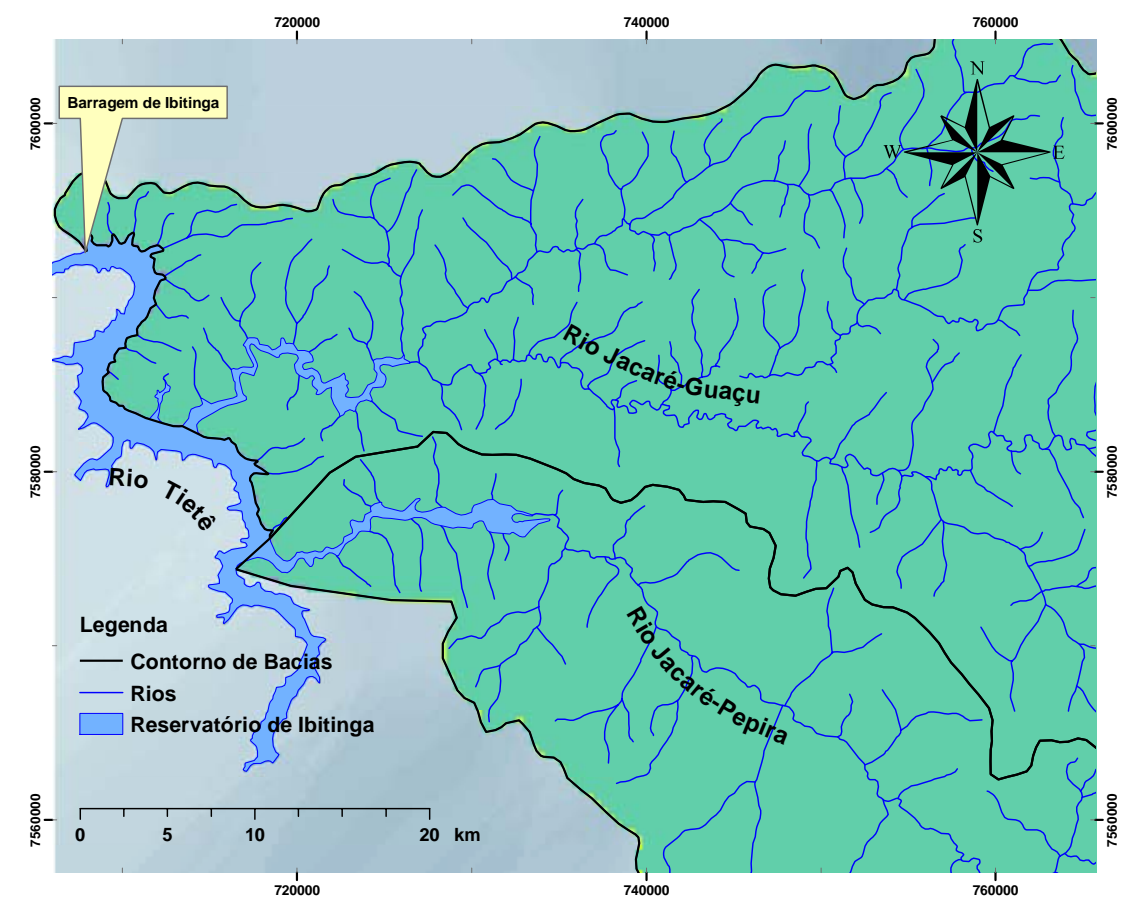

Figura 15 - Contornos das bacias do sistema Jacaré na região dos exutórios 


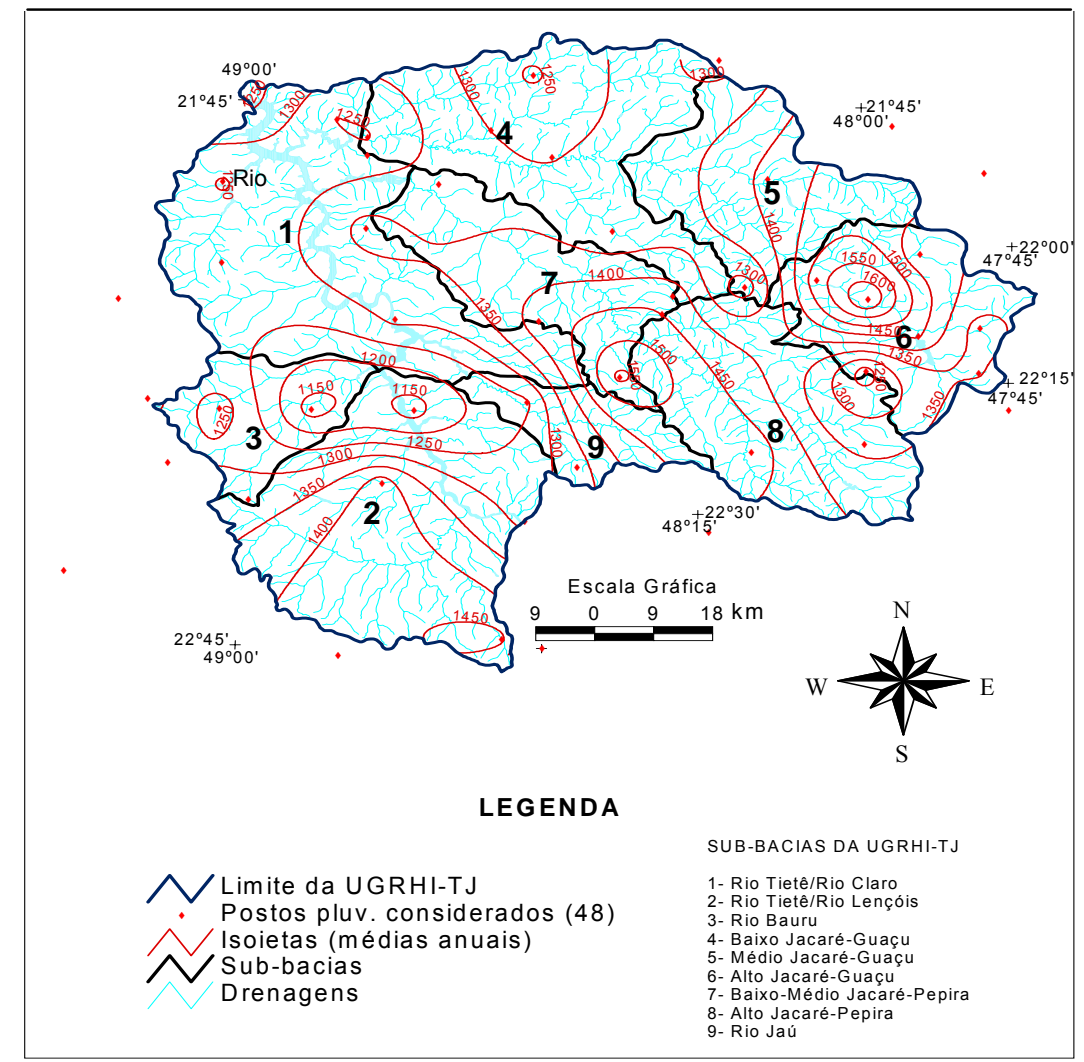

Figura 16 - Isoietas médias anuais na UGRHI -TJ; distribuição de postos pluviométricos utilizados e contorno de sub-bacias (IPT, 2003)

\subsubsection{Precipitação}

$\mathrm{Na}$ área de estudo como na maior parte do Estado, o período chuvoso ocorre de outubro a março, sendo o trimestre mais chuvoso de dezembro a fevereiro. O período mais seco vai de abril a setembro, com o trimestre mais seco entre junho e agosto. Em SANT'ANNA NETO (1995) é apresentada uma carta síntese da variação têmporo-espacial das chuvas, definindo oito "unidades regionais" e 25 "subunidades homogêneas" para o Estado de São Paulo, estando a área de estudo compreendida na unidade Cuestas Basálticas, subunidade São Carlos/São Pedro; e na unidade oeste, subunidade Vale Médio do Rio Tietê. As duas unidades juntas abrangem uma área igual à aproximadamente três vezes a área de estudo, contudo, alguns resultados são apreciados em seguida. A 
primeira unidade corresponde à região mais elevada do centro oeste paulista, com altitudes entre 700 e 900 metros, apresentando chuvas médias anuais entre 1.500 e $1.800 \mathrm{~mm}$ e cerca de 40 a $50 \%$ das chuvas anuais localizadas no trimestre mais chuvoso. A segunda unidade corresponde à região central do Estado, no entorno da Cidade de Bauru, abrangendo a parte leste da área de estudo, registra altitudes entre 300 e 500 metros e chuvas médias anuais entre 1.300 e $1.500 \mathrm{~mm}$. Tem como características, forte estiagem no inverno e grande variação de ano para ano. Cerca de 75 a $80 \%$ das chuvas ocorrem no período mais chuvoso, e 20 a 25\% no período mais seco. Num período de 23 anos (19711993), para o conjunto das duas unidades, nove anos apresentaram-se com padrão normal, nove chuvosos e cinco secos, sendo considerado por SANT'ANNA NETO (1995) os seguintes valores de precipitação anual para definir os anos secos e chuvosos: anos normais/habituais, 1.423 a 1.628 mm; anos com tendência a chuvosos, 1.628 a $1.730 \mathrm{~mm}$; anos chuvosos, superiores a $1.730 \mathrm{~mm}$; anos com tendência a secos, 1.320 a $1.423 \mathrm{~mm}$.

Em IPT (2003) foram considerados dados de séries históricas disponíveis de 48 postos pluviométricos com área de influência na UGRHI-TJ e determinadas as isoietas de médias anuais (Figura 16).

A UGRHI-TJ foi objeto de divisão em unidades hidrográficas, utilizando-se de critérios hidrológicos e climáticos, sendo os limites definidos a partir dos divisores principais e das bacias de captação dos rios de maior porte, além de outros aspectos fisiográficos. Neste processo as bacias dos rios Jacaré-Guaçu e Jacaré-Pepira foram divididas em cinco sub-bacias: Baixo, Médio e Alto JacaréGuaçu, Baixo-Médio e Alto Jacaré-Pepira, respectivamente sub-bacias 4, 5, 6, 7 e 8. As precipitações anuais médias para as sub-bacias que compõem o sistema Jacaré encontram-se na Tabela 8.

Em MATOS (1987), resultados pluviométricos obtidos da análise de dados de 57 estações, distribuídas na área das duas bacias, referentes a um período de 15 anos (1970 a 1984), indicam precipitações anuais médias de 1550 e 1500 mm, para as regiões montantes, respectivamente, das bacias do Jacaré-Guaçu e Jacaré-Pepira, e $1400 \mathrm{~mm}$ para a região jusante de ambas as bacias. O referido trabalho analisou a variação do regime de chuvas para a região e obteve valores inferiores a $10 \%$ nesse período. 
Apesar dos três trabalhos mencionados apresentarem resultados relativamente próximos, quando considerados na área de estudo, o do IPT (2003) foi tomado como referência neste trabalho por ter utilizado series históricas em uma avaliação sistemática e mais específica para a área de estudo. A precipitação média na ára das duas bacias, determinada pelo método de isoietas, foi de $1371,2 \mathrm{~mm}$.

Tabela 8 - Precipitação média anual histórica nas sub-bacias do sistema Jacaré, segundo divisão das sub-bacias em IPT (2003).

\begin{tabular}{c|l|c|c}
\hline \multicolumn{1}{c}{ Sub-bacia $\mathrm{N}^{\mathrm{N}}$} & \multicolumn{1}{c}{ Área $\left(\mathrm{km}^{2}\right)$} & Precipitação Anual (mm) \\
\hline \hline 4 & Baixo Jacaré-Guaçu & 1.708 & 1.257 \\
\hline 5 & Médio Jacaré-Guaçu & 1.066 & 1.341 \\
\hline 6 & Alto Jacaré-Guaçu & 1.113 & 1.402 \\
\hline 7 & Baixo /Médio Jacaré-Pepira & 1.052 & 1.290 \\
\hline 8 & Alto Jacaré-Pepira & 1.411 & 1.395 \\
\hline TOTAL & $6350^{(*)}$ & \\
\hline
\end{tabular}

\subsubsection{Drenagem e Fluviometria}

A bacia do Rio Jacaré-Guaçu, com $4.161 \mathrm{~km}^{2}$ de área de captação, é limitada ao Sul pela bacia do Rio Jacaré-Pepira, ao Norte pela bacia do Rio São Lourenço, a Nordeste pela bacia do Rio Mogi-Guaçu, a Leste pela bacia do Rio Piracicaba e a Oeste pelo Rio Tietê. O Rio Jacaré-Guaçu tem como principais tributários os rios: Monjolinho, Chibarro, Itaqurrê e Boa Esperança do Sul, e ribeirões: das Cruzes, São João, da Onça e Bonito. O Rio Jacaré-Guaçu é formado pela junção dos ribeirões do Lobo e do Feijão. Essa confluência se dá em uma altitude de aproximadamente $700 \mathrm{~m}$ acima do nível do mar, a jusante da Usina Hidrelétrica do Ribeirão do Lobo, servindo de limite para três municípios, Brotas, Itirapina e São Carlos.

Com $2.587 \mathrm{~km}^{2}$ de área de captação, a bacia do Rio Jacaré-Pepira é limitada ao Norte e Nordeste pela bacia do Rio Jacaré-Guaçu, a Sudeste e Sul pelas bacias dos rios Jaú e Piracicaba, respectivamente, a Leste pela bacia do

\footnotetext{
${ }^{(*)}$ As áreas das bacias foram reavaliadas neste trabalho devido a considerações diferentes (das feitas em IPT, 2003) sobre seus contornos na região dos exutórios das Bacias Hidrográficas do Jacaré-Guaçu e Jacaré-Pepira.
} 
Rio Corumbataí e a Oeste pelo Rio Tietê. O Rio Jacaré-Pepira é formado pela junção dos ribeirões do Jardim e Tamanduá, cujas nascentes se localizam aproximadamente na cota topográfica de 900 m, na serra de São Pedro.

A confluência dos rios Jacaré-Guaçu, Jacaré-Pepira e Tietê ocorre dentro do lago criado pela Barragem de Ibitinga (Figura 15), em uma cota aproximada de $410 \mathrm{~m}$.

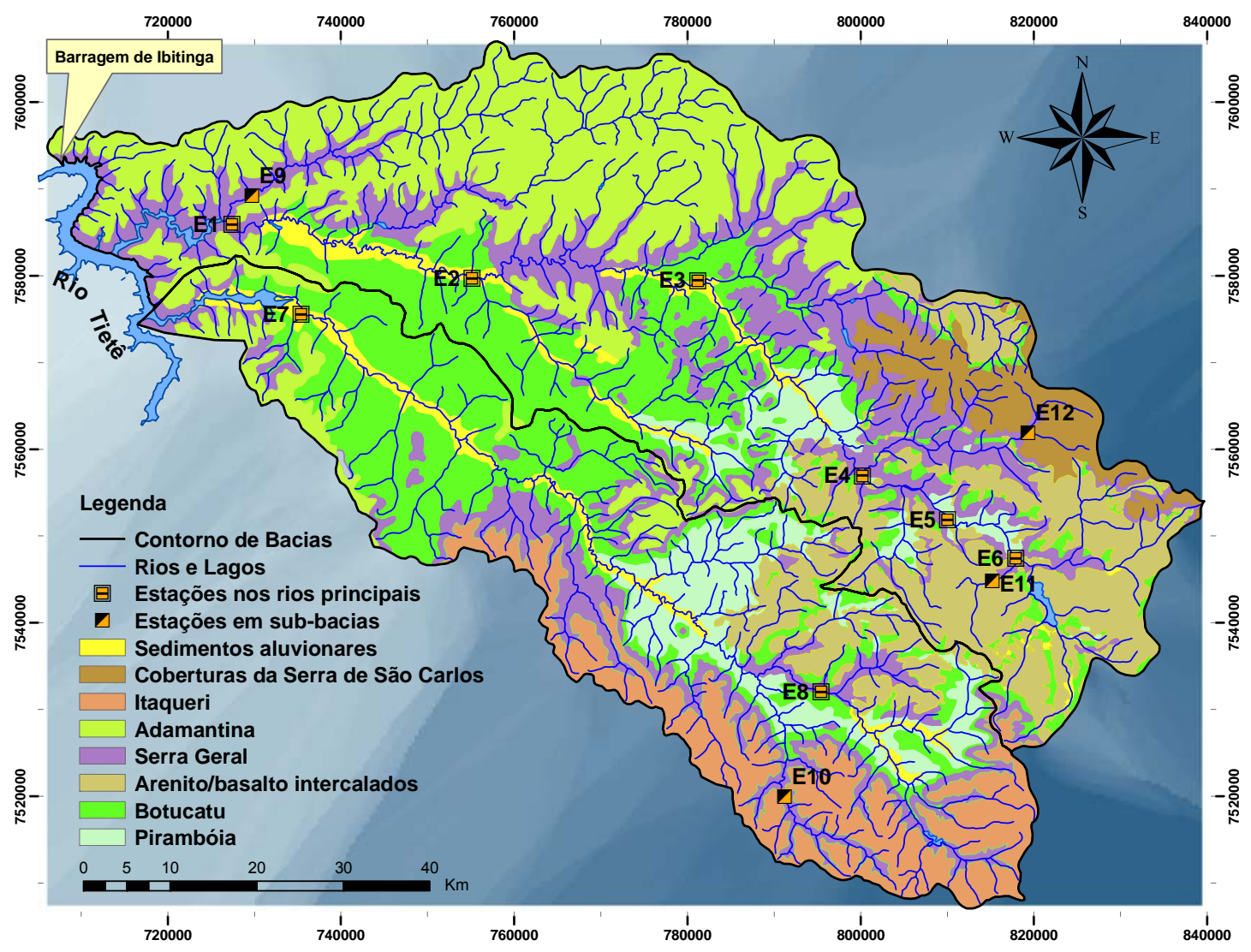

Figura 17 - Localização de estações fluviométricas (E1 a E12) em relação à drenagem e formações geológicas

Foram selecionadas 12 estações fluviométricas na área de estudo, 9 estações na bacia do Jacaré-Guaçu e 3 estações na bacia do Jacaré-Pepira (Figura 17 e Tabela 9), tendo sido analisadas as séries históricas, abrangendo dados de vazão de 1938 a 2004, com períodos de registro de aproximadamente 2 a 35 anos, por estação, com média de 10,6 anos. Os dados foram obtidos junto ao $\mathrm{DAEE} / \mathrm{CTH}^{1}$ e $\mathrm{ANA}^{1}$, esta última, portadora dos dados provenientes das

\footnotetext{
${ }^{1}$ DAEE - Departamento de Águas e Energia Elétrica do Estado de São Paulo,

CTH - Centro Tecnológico de Hidráulica do Estado de São Paulo.
} 
estações então operadas pelo DNAEE ${ }^{2}$. O objetivo principal do estudo das séries fluviométricas neste trabalho foi o de estimar os volumes drenados pelo Aqüífero Guarani, ao longo dos rios principais. Este procedimento é descrito no modelo conceitual.

Tabela 9 - Volumes anuais em estações fluviométricas ao longo dos rios JacaréGuaçu, Jacaré-Pepira e tributários (fonte: DAEE/CTH, ANA, 2004)

\begin{tabular}{|c|c|c|c|c|c|c|c|}
\hline No & $\begin{array}{l}\text { Vol. total } \\
\text { Vt }\left(10^{6} \mathrm{~m}^{3}\right)\end{array}$ & $\begin{array}{l}\text { Vol. de base } \\
\operatorname{Vb}\left(10^{6} \mathrm{~m}^{3}\right)\end{array}$ & $\begin{array}{c}\mathrm{Vb} / \mathrm{Vt} \\
(\%)\end{array}$ & $\begin{array}{c}\text { Formação } \\
\text { ou } \\
\text { sedimentos }\end{array}$ & $\begin{array}{c}\text { Área de } \\
\text { drenagem } \\
\left(\mathrm{km}^{2}\right)\end{array}$ & $\begin{array}{l}\text { UTM-E } \\
\text { UTM-N }\end{array}$ & Rio \\
\hline $\mathrm{E} 1$ & $1.481,8$ & $1.050,0$ & 70,9 & $\begin{array}{c}\text { formações } \\
\text { conjuntas }\end{array}$ & 3.532 & $\begin{array}{l}727412 \\
7585930\end{array}$ & Jacaré-Guaçu \\
\hline E2 & $1.218,9$ & 889,2 & 72,9 & $\begin{array}{l}\text { formações } \\
\text { conjuntas }\end{array}$ & 2.842 & $\begin{array}{l}755130 \\
7579710\end{array}$ & Jacaré-Guaçu \\
\hline E3 & 764,0 & 553,8 & 72,5 & $\begin{array}{l}\text { formações } \\
\text { conjuntas }\end{array}$ & 1882 & $\begin{array}{l}781183 \\
7579476\end{array}$ & Jacaré-Guaçu \\
\hline $\mathrm{E} 4$ & 359,5 & 282,7 & 78,6 & $\begin{array}{l}\text { formações } \\
\text { conjuntas }\end{array}$ & 805 & $\begin{array}{l}800211 \\
7556963\end{array}$ & Jacaré-Guaçu \\
\hline E5 & 246,5 & 199,0 & 80,7 & $\begin{array}{l}\text { formações } \\
\text { conjuntas }\end{array}$ & 607 & $\begin{array}{l}810032 \\
7551884\end{array}$ & Jacaré-Guaçu \\
\hline E6 & 199,6 & 164,9 & 82,6 & $\begin{array}{l}\text { formações } \\
\text { conjuntas }\end{array}$ & 516 & $\begin{array}{l}817887 \\
7547410 \\
\end{array}$ & Jacaré-Guaçu \\
\hline E7 & 792,9 & 692,9 & 87,4 & $\begin{array}{l}\text { formações } \\
\text { conjuntas }\end{array}$ & 2.403 & $\begin{array}{l}735394 \\
7575576\end{array}$ & Jacaré-Pepira \\
\hline E8 & 216,2 & 125,1 & 79,9 & $\begin{array}{l}\text { formações } \\
\text { conjuntas }\end{array}$ & 537 & $\begin{array}{l}795413 \\
7532021\end{array}$ & Jacaré-Pepira \\
\hline E9 & 127,6 & 77,3 & 60,6 & Adamantina & 337 & $\begin{array}{l}729734 \\
7589258\end{array}$ & São João \\
\hline E10 & 49,7 & 31,5 & 63,4 & Itaqueri & 100 & $\begin{array}{l}791224 \\
7519995\end{array}$ & $\begin{array}{l}\text { Ribeirão } \\
\text { Pinheiros }\end{array}$ \\
\hline E11 & 66,9 & 62,8 & 93,9 & Botucatu & 47 & $\begin{array}{l}815201 \\
7544851\end{array}$ & $\begin{array}{l}\text { Ribeirão da } \\
\text { Onça }\end{array}$ \\
\hline E12 & 11,1 & 7,3 & 65,8 & Cob. SSC $\left(^{(*)}\right.$ & 22 & $\begin{array}{l}819321 \\
7561890\end{array}$ & $\begin{array}{l}\text { Córrego do } \\
\text { Gregório }\end{array}$ \\
\hline
\end{tabular}

$\left({ }^{*}\right)$ Coberturas da Serra de São Carlos

A quantidade significativamente menor de estações consideradas na bacia do Jacaré-Pepira, em relação à do Jacaré-Guaçu, é atribuída à escassez dessas estações na primeira. Entre as estações, 6 estão ao longo do Jacaré-Guaçu (E1 a E6) e 2 ao longo do Jacaré-Pepira (E7 e E8), as demais (E9 a E12) foram escolhidas de modo a representar mais fielmente a drenagem de formações e sedimentos específicos, em bacias-referência, distribuídos entre as formações Adamantina (E9), Itaqueri (E10), Botucatu (11) e Sedimentos da Serra de São Carlos (E12), visando estabelecer as contribuições de escoamento de base, originárias das mesmas, nos dois rios principais.

\footnotetext{
${ }_{1}^{1}$ ANA - Agência Nacional de Águas.

2 DNAEE - Departamento Nacional de Águas e Energia Elétrica.
} 
A análise e tratamento das séries fluviométricas diárias incluiu a determinação de vazões totais anuais médias, vazões mínimas anuais médias e separação do escoamento de base a partir da geração dos respectivos hidrogramas.

Para a separação dos escoamentos de base foi utilizado o método Recursive Digital Filter (NATHAN e McMAHON, 1990). Esse método foi escolhido por ser de fácil automação (implementação numérica por planilha eletrônica), apresentar boa coincidência com os métodos tradicionais de separação manual e por apresentar bons resultados para bacias de diferentes tamanhos e médias pluviométricas, em comparação a outros métodos automatizados, sobretudo quando da utilização de dados diários de vazão (ARNOLD e ALLEN, 1999). Contudo, esse método requer algum conhecimento sobre as quantidades de vazão total e/ou de base para servir como referência. Os hidrogramas com separação de fluxo de base, utilizados neste trabalho, encontram-se no Apêndice A e a estratégia e critério utilizados na sua aplicação são descritos no modelo conceitual.

Os valores de $\mathrm{Vb}$ e $\mathrm{Vb} / \mathrm{Vt}$, nos quais $\mathrm{Vb}$ e $\mathrm{Vt}$ são, respectivamente, os volumes de base e volume total, obtidos do método de separação, para as estações localizadas nos dois rios principais (E1 a E8), indicam quantidades do escoamento de base proveniente do conjunto de sistemas aqüíferos que compõem o SAG na região de estudo. Estes sistemas, que englobam o Aqüífero Guarani (formações Botucatu/Pirambóia), o aqüifero Bauru-basaltos (formação Serra Geral e formações do Grupo Bauru) e sedimentos mais recentes, são referenciados na Tabela 9 como "formações conjuntas". Para os valores de Vt, o efeito conjunto do total das formações é mais claro e dispensa descrição.

Para a bacia do Jacaré-Guaçu, os resultados de vazão indicam uma proporção significativamente maior de escoamento de base na sua parte montante em relação à jusante, enquanto na bacia do Jacaré-Pepira esse comportamento se inverte. Esses dados são coerentes com a proporção de confinamento do Aqüifero Guarani, que guarda também relação inversa entre essas regiões das bacias, como observado na Figura 17.

Para as estações localizadas em rios que drenam as formações Serra Geral e do Grupo Bauru (E9, E10 e E12), é verificada menor proporção de escoamento de base, quando comparada a de estações nos rios principais. Contrariamente, a 
drenagem da Formação Botucatu (E11) indica componente de vazão de base significativamente superior às demais.

\subsubsection{Poços}

Os dados referentes aos poços cadastrados na área de estudo, obtidos inicilalmente junto ao Comitê da Bacia Hidrográfica do Tietê/Jacaré - CBH-TJ, produzidos pelo IPT (2003), foram em um segundo momento sistematizados, tendo como fonte apenas o acervo do DAEE por possuir centralização e maior quantidade de informação. Foi identificado um total de 246 poços cadastrados, até março de 2005, na área das duas bacias, tendo como aqüífero principal de captação o Aqüífero Guarani (formações Botucatu/Pirambóia). Após tratamento desses dados, restaram 231 poços (Figura 18).

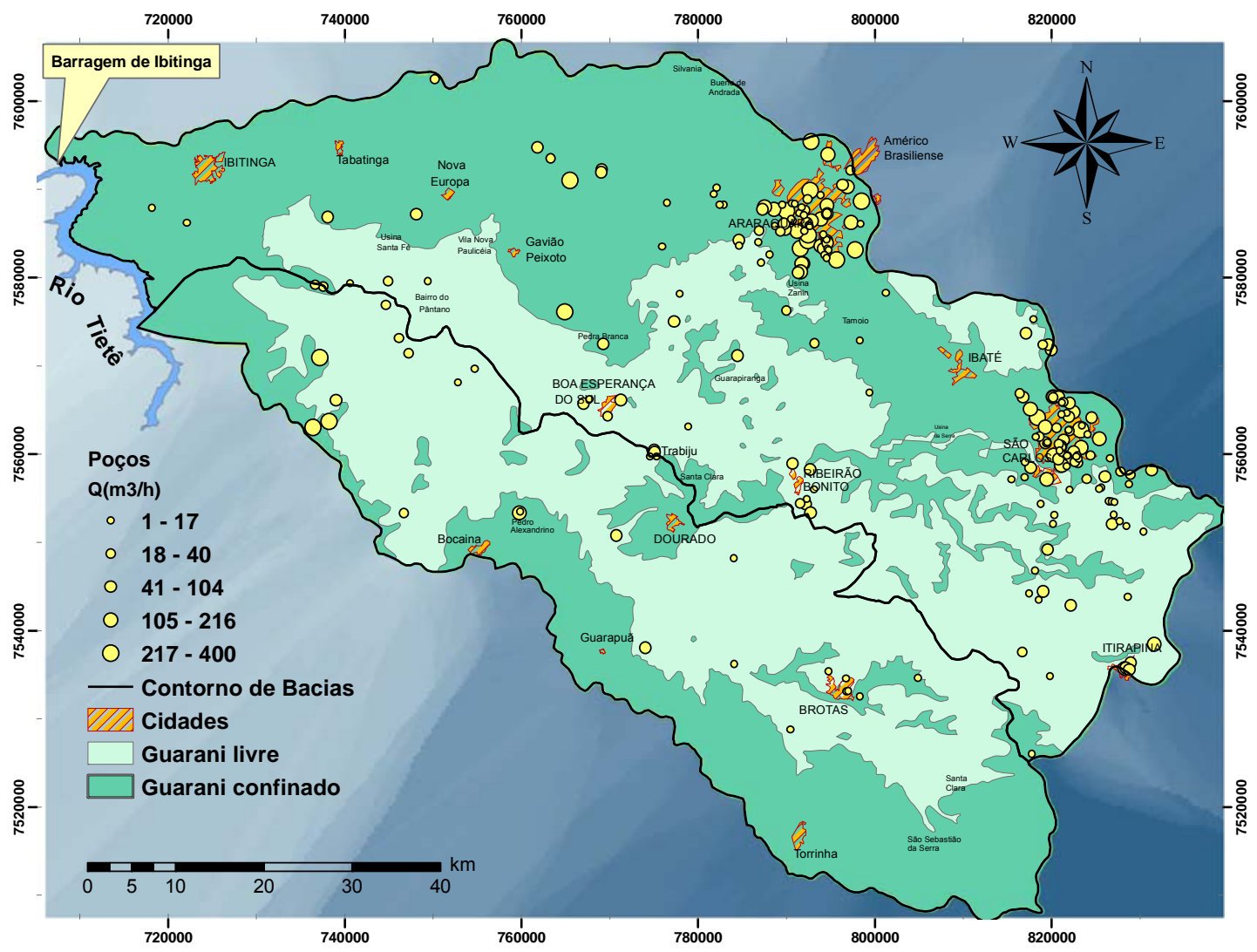

Figura 18 - Distribuição de poços cadastrados do Aqüífero Guarani, em regiões de aqüífero livre e confinado, nas bacias do Jacaré-Guaçu e Jacaré-Pepira 
Os demais foram descartados por possuírem dados contraditórios de posicionamento (em coordenadas UTM) e/ou entre dados de vazão e posição em relação às formações do Grupo Bauru e Formação Serra Geral (Anexo B). Esse processo de tratamento foi implementado com a utilização do georeferenciamento e ferramentas de visualização SIG.

As vazões variam significativamente entre os 231 poços identificados, de 1 a $400 \mathrm{~m}^{3} / \mathrm{h}$, com média de $61,3 \mathrm{~m}^{3} / \mathrm{h}$ e desvio-padrão de $81,2 \mathrm{~m}^{3} / \mathrm{h}$. Ente os 231 poços identificados, $14 \%$ não tinham dados de vazão definidos. A esses foi atribuído o valor médio de vazão. A maioria, 146 poços, encontra-se na região de aqüifero confinado, com uma vazão média de $73,8 \mathrm{~m}^{3} / \mathrm{h}$, enquanto o restante, 85 poços, na região de aqüífero livre, possui vazão média de $39,7 \mathrm{~m}^{3} / \mathrm{h}$.

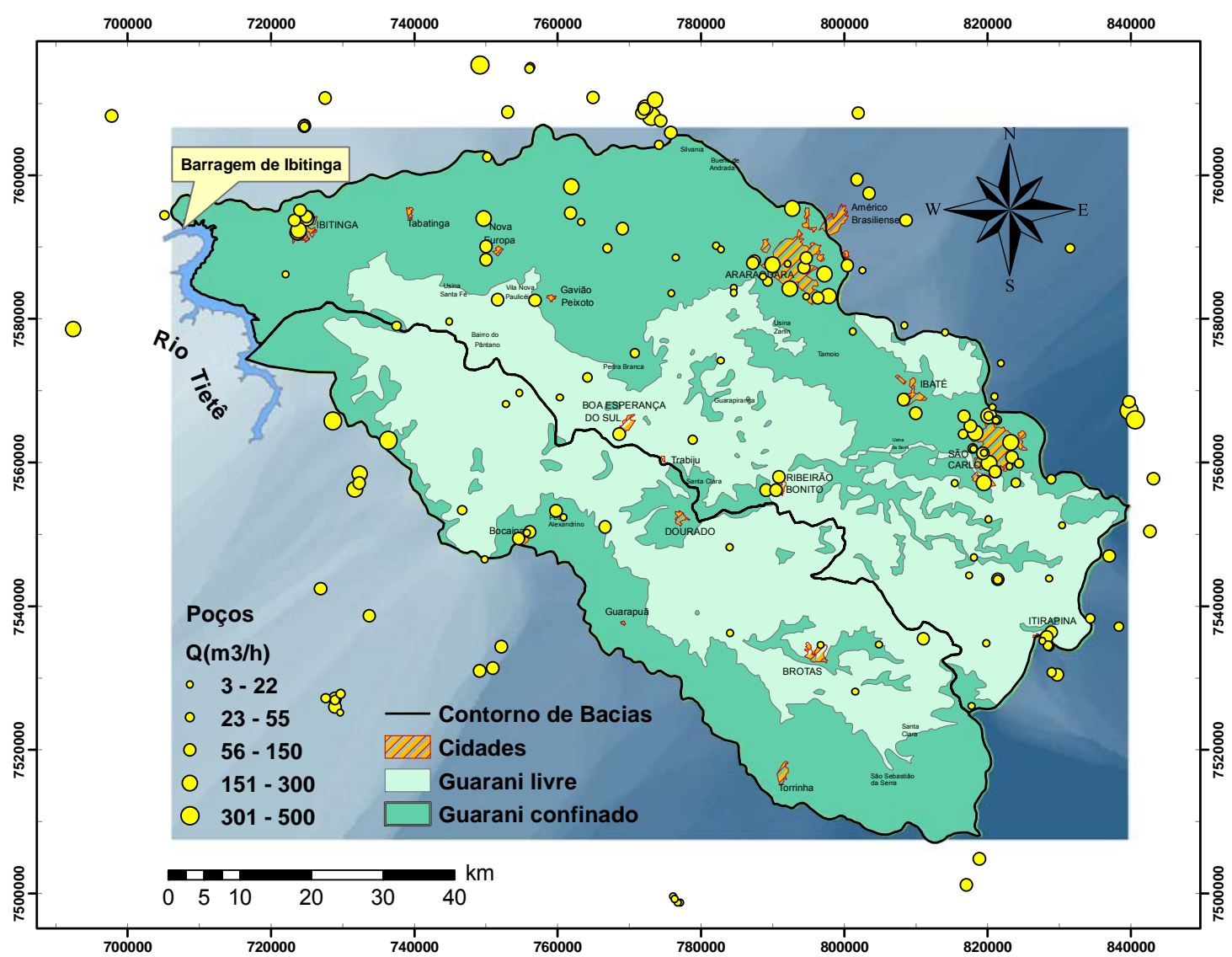

Figura 19 - Distribuição de poços cadastrados do Aqüífero Guarani, em regiões de aqüífero livre e confinado, nas bacias do Jacaré-Guaçu, Jacaré-Pepira e entorno 
Um outro conjunto de poços, num total de 170 (Figura 19), contendo dados hidráulicos e estratigráficos mais confiáveis, foi selecionado visando estimar a superfície potenciométrica para a região das bacias e seu entorno, bem como, fornecer dados sobre a estratigrafia local (Anexo A). Na escolha, foi considerada a necessidade de tomar dados mais bem distribuídos, alguns fora do limite das bacias, para investigar possíveis contribuições de fluxo lateral na área de estudo. A avaliação da qualidade desses dados e sua complementação se deram em parte com uma campanha de medições de NE e posicionamento de um número selecionado de poços desse conjunto. O detalhamento sobre essa campanha de medição encontra-se na seção 3.4 .

\subsubsection{Evapotranspiração}

Em solos vegetados, o processo combinado de evaporação pela superfície do solo e transpiração pelas plantas é considerado evapotranspiração. Provavelmente, entre os processos hidrológicos, é o mais difícil de ser quantificado devido à grande quantidade de parâmetros dependentes. Esses parâmetros podem ser agrupados em dois conjuntos: os referentes aos elementos meteorológicos e os referentes aos elementos físico-biológicos. Assim, a quantificação deste processo hidrológico está sujeita à incerteza desses elementos, como descrito nos métodos indiretos que estimam a evapotranspiração potencial (PENMAN, 1956; THORNTHWAITE, 1948). Em DAEE (1974), os dados de evaporação obtidos dos postos meteorológicos da área de estudo foram considerados bastante deficientes e duvidosos, devido à deficiência de séries de dados de evaporação de tanque Classe-A.

Em CUNHA (2003), os modelos de Penman e Thornthwaite foram comparados, juntamente com o método de utilização de lisímetro (evapotranspiração real), em uma região de afloramento, localizada em região mais a montante da área de estudo. Os dois primeiros mostraram-se inadequados para estimar a evapotranspiração real em regiões com invernos muito secos e presença de solo arenosos, características da área de estudo, e o método utilizando lisímetro mediu uma evapotranspiração real de $651 \mathrm{~mm}$, monitorado 
durante um ano. MATOS (1987) estimou a evapotranspiração total anual, em 12 estações meteorológicas distribuídas na região da área de estudo e seu entorno. Foram utilizados os métodos de Thornthwaite e Mather, Penman, Turc e medidas diretas em tanque Classe $A$, obtendo melhores resultados pelo método Thornthwaite e Mather, para evapotranspiração real e para solos profundos (armazenamento de solo igual a $150 \mathrm{~mm}$ ), mais adequado aos solos das bacias do sistema Jacaré. Foram obtidas deste trabalho isolinhas de evapotranspiração real anual de 960 a 1100 mm, com valores crescentes de SE-NW (montante para jusante) das bacias.

Quando comparados os dois últimos trabalhos, para uma mesma região (região montante da área de estudo), verifica-se os valores de 960 e $651 \mathrm{~mm}$, respectivamente, para os trabalhos de MATOS (1987) e CUNHA (2003), o que corresponde a um desvio relativo, em torno da média, de 38,4\%. Contudo, neste trabalho foram considerados, como referência, os valores de evapotranspiração obtidos dos referidos trabalhos.

\subsection{HIDROGEOLOGIA}

\subsubsection{Características regionais}

O Aqüífero Guarani no Estado de São Paulo, constituído pelas formações Botucatu e Pirambóia, está intercalado entre as camadas permianas do Grupo Passa Dois e os derrames basálticos cretáceos da Formação Serra Geral. Tratase de um aqüífero livre apenas nas bordas da bacia e confinado em $90 \%$ de sua extensão (DAEE, 1974). A distinção entre as regiões do Guarani livre e confinado

pode ser feita baseada na análise do coeficiente de armazenamento, já que o mesmo é inversamente proporcional ao grau de confinamento (TEISSEDRE et al., 1982).

Segundo estudo hidrogeológico realizado na região Administrativa 6 Ribeirão Preto - SP (DAEE, 1974), dos 300 m de espessura local da Formação Pirambóia, os 100 a 200 m superiores, adjacentes à base da Formação Botucatu, 
são considerados aqüífero de média qualidade, devido ao pequeno teor de finos na areia. Devido à semelhança entre essa porção superior da Formação Pirambóia e a Formação Botucatu, é difícil distinguir a transição entre elas. Segundo a amostragem de poços na região, ambas são consideradas como um aqüífero unificado, sendo a parte inferior da Formação Pirambóia, que jaz sobre a Formação Corumbataí, principalmente argilosa, definida como aquitardo, não sendo considerada como importante fonte regional de água, excluindo-se solução de pequenos problemas de abastecimento localizado. Em PIUCI e DINIZ (1985), os poços que penetram inteiramente o Guarani não apresentam conteúdo técnico suficiente que justifique a separação entre as duas formações aqüíferas, e as características gerais das rochas indicam a condição de isotropia do Aqüífero Guarani.

\subsubsection{Características dimensionais}

As rochas que constituem o Aqüífero Guarani abrangem toda a área de captação das bacias estudadas $\left(6.748 \quad \mathrm{~km}^{2}\right)$, superficialmente ou subsuperficialmente, estando parcialmente cobertas por derrames basálticos em seus limites (Figura 13). Segundo dados obtidos de processamento do SIG, o Aqüífero aflora em $46 \%$ da área de estudo (aproximadamente $3.100 \mathrm{~km}^{2}$ ), estendendo-se pelo centro da área de estudo, desde o extremo leste da região de Itirapina até as proximidades do reservatório de lbitinga, expandindo-se a noroeste, com surgências a nordeste e algumas exceções, principalmente, na região central do divisor das duas bacias (Serra de Dourado). Sedimentos recentes de idade Quaternária também recobrem o Guarani ao longo dos rios Jacaré-Guaçu e Jacaré-Pepira na forma de sedimentos aluvionares. Considerando-se a interação hidráulica natural entre o aqüífero e os dois rios principais, estabelecida através destes sedimentos, não foi feita distinção das áreas de ocorrência dos aluvionares em relação à área identificada como Guarani livre ou não-confinado.

De acordo com CORREAA (1995), segundo características das isolinhas de contorno estrutural de base, isópacas e piezometria, o Aqüífero tem um mergulho 
SE-NW, com espessuras saturadas variando de 150 a 250 m na região. Em IPT (2003), dados de poços em regiões da área de estudo indicaram espessuras máximas do Aqüífero: a NW (município de Bocaina) $229 \mathrm{~m}$, a NE (município de Araraquara) 263 m e no centro-norte (município de Gavião Peixoto) 140 m. Uma comparação desses dados com os obtidos neste trabalho, a partir do processamento com SIG, é feita na seção 4.2.2.1.

\subsubsection{Características das camadas confinantes e semiconfinates}

O aquitardo da base do Aqüífero Guarani é constituído por diferentes litótipos, correspondentes à base da Formação Pirambóia e à Formação Corumbataí, esta última de idade paleozóica. É representado, do topo para a base, por arenitos argilosos, siltitos arenosos, argilitos folhelhos, bancos de calcário e eventuais intercalações de lentes arenosas de diferentes níveis (PIUCI e DINIZ, 1985). Esse aquitardo funciona hidraulicamente como camada semiconfinante da base do Aqüífero Guarani, e dependente das cargas hidráulicas entre este e o Guarani por entrada ou saída de água por drenança. Pela inexistência de valores calculados de condutividade vertical, e pela característica das rochas, que indica ser essa condutividade muito baixa, esta camada é comumente considerada como limite impermeável da base do Aqüifero (DAEE, 1974; CORRÊA, 1995).

Pelas características gerais, já apresentadas, dos derrames basálticos, que incluem intercalações de arenitos, diaclasamentos verticais e horizontais, e por grandes linhas de descontinuidade transversais, o confinamento do topo do Aqüífero Guarani é caracterizado, sobremodo, por uma camada semiconfinante. Esta camada é definida pelo contorno estrutural de base da Formação Serra Geral que se comporta como uma unidade aqüífera constituída por camadas com porosidade predominantemente secundária (fraturamento), apresentando-se litologicamente homogênea e hidraulicamente anisotrópica, com circulação em meio fraturado; é um aqüífero em condições livres em toda a área estudada. Segundo ROSA FILHO et al. (2003), a formação funciona também como reservatório, além de seu caráter de barreira hidráulica. 
Neste trabalho, de forma simplificada, o Aqüífero Guarani é classificado ou subdividido comumente em áreas onde ele é simplesmente livre ou confinado, contudo, isso não deve diminuir o entendimento hidrogeológico de aqüífero semiconfinado.

Acima do Aqüífero Serra Geral, as formações do Grupo Bauru, na sua maioria Formação Adamantina, formam o Aqüífero Bauru, constituindo-se no aqüífero superior da seqüência, formado por camadas de porosidade primária intersticial na qual ocorrem condições livres. Os derrames basálticos superiores encontram-se, em geral, recobertos pelos sedimentos da Formação Adamantina, ao passo que os derrames inferiores são recobertos pelos arenitos da Formação Botucatu, compondo os arenitos intercalares, aqui denominados de arenito/basalto intercalados. Na região de São Carlos ocorre a seqüência completa, da base para o topo: Aqüífero Guarani (formações Pirambóia/Botucatu), basaltos inferiores (intrusões), derrames basálticos superiores (extrusões) e Formação Adamantina (CORRÊA, 1995) (Figura 20). Os derrames basálticos superiores juntamente com as formações do Grupo Bauru, ou mais recentes, formam o pacote de estratigrafia e espessura variáveis ao longo da área de estudo, compondo a unidade hidroestratigráfica denominada de Aqüífero Baurubasaltos.

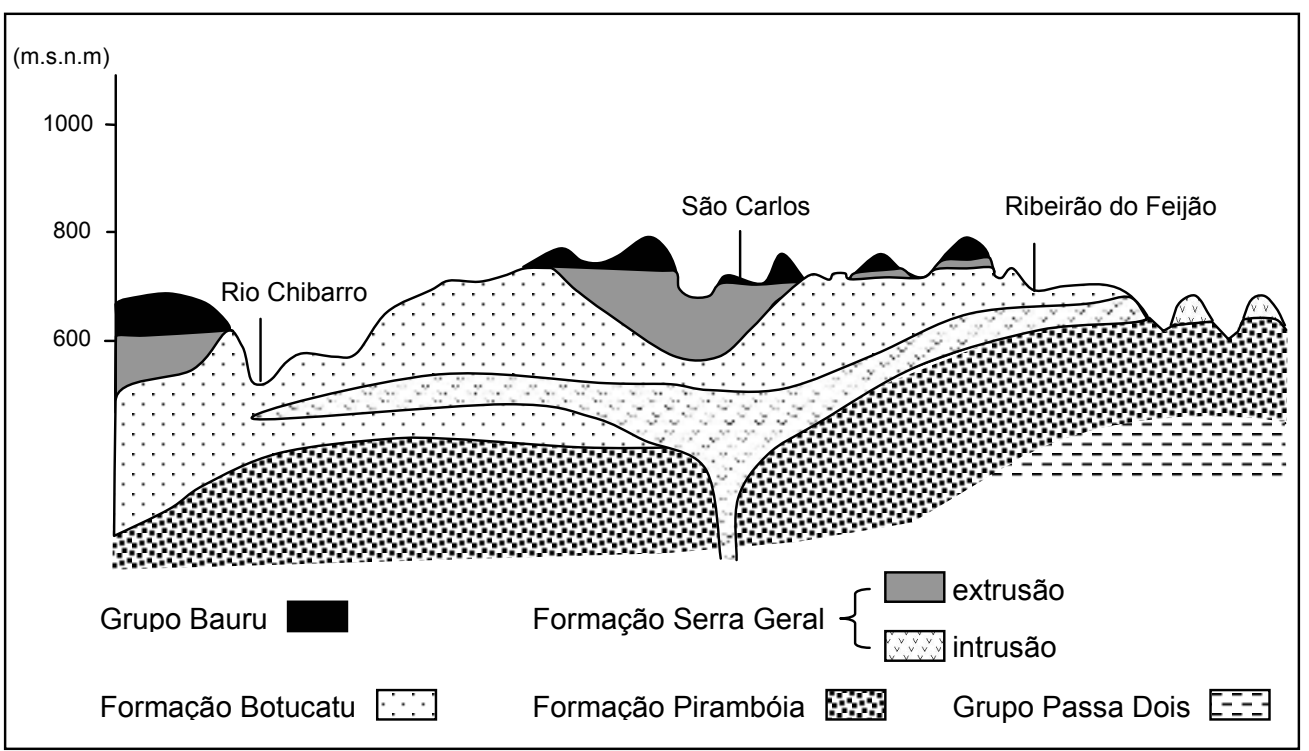

Figura 20 - Estratigrafia característica da região de São Carlos (FREITAS, 1996) 


\subsubsection{Recarga e fluxo natural}

A recarga natural ocorre segundo dois mecanismos principais: por meio de infiltração (direta) das águas de chuva, na área de afloramento, e de forma retardada (indireta) na área confinada, por infiltração vertical (drenança) ao longo de descontinuidades das rochas do pacote confinante, onde a carga potenciométrica favorece os fluxos descendentes. A disposição geral das áreas sujeitas a essas duas formas de recarga é apresentada na Figura 18 e Figura 19. Contudo, as áreas consideradas de afloramento, apresentam comumente alguma parcela de condição mista de recarga, decorrente de camadas semiconfinantes. Tal condição é estabelecida pela presença intercalada de rochas basálticas fraturadas da Formação Serra Geral e os arenitos das Formações Botucatu e Pirambóia (arenitos intercalares) (ALMEIDA e BARBOSA, 1953; CORRÊA, 1995), e aqui mencionada como arenito/basalto intercalados. Fora das zonas de afloramento do Aqüífero Guarani, encontram-se regiões onde o nível da superfície potenciométrica é superior ao topo do aqüífero, invertendo o fluxo descendente sobre o aqüífero, como verificado na área de estudo, próximo ao reservatório de Ibitinga. CORRÊA (1995) conclui que as áreas de recarga encontram-se definidas graças à ocorrência conjunta de pluviosidade elevada associada a solos permeáveis, aos gradientes topográficos e à direção de inclinação das camadas geológicas. Na região de Ribeirão Preto, reconhecida por possuir características hidrogeológicas semelhantes às da área de estudo (DAEE, 1974), foi realizado um balanço hídrico utilizando-se dados de investigações isotópicas, e em seguida verificado por um modelo numérico simplificado, obtendo-se valores de recarga efetiva do Aqüífero Guarani em torno de 17\% da precipitação (SMA, 2004).

Os níveis piezométricos registrados em DAEE (1974) revelam uma tendência regional do fluxo subterrâneo de SE-NW, em direção à calha do Rio Tietê, e secundariamente em direção ao vale dos principais rios (Jacaré-Guaçu e Jacaré-Pepira). Segundo (CORRÊA, 1995), esses vales, cuja influência sobre o Aqüífero diminui de SE-NW, constituem verdadeiros drenos do Aqüífero ao Rio Tietê. Esse interflúvio sugere uma indiferenciação do Aqüífero na região próxima aos exutórios das duas bacias. Finalmente, pela observação dos níveis piezométricos, sugere a ocorrência de fluxo subterrâneo lateral, no sentido N-S 
(em direção ao vale do Rio Jacaré-Guaçu), entre Araraquara e Ibitinga, bem como, um fluxo na região da Serra de São Pedro (bacia do Jacaré-Pepira), no sentido N-S.

\subsubsection{Características Hidrodinâmicas}

Dados de características hidrodinâmicas do Aqüífero Guarani, para a região das duas bacias de estudo e seu entorno (UGRHI-TJ), foram sistematizados em DAEE (1974), CORRÊA (op cit). e IPT (2003). A Tabela 10, Tabela 11 e Tabela 12 apresentam os valores obtidos, respectivamente, em cada um dos trabalhos. Foram investigados valores de condutividade hidráulica $(K)$, transmissividade $(T)$, coeficiente de armazenamento $(S)$, porosidade efetiva $(n)$ e capacidade específica (Q/s). Em DAEE (1974), os dados de $T$, S e $n$ foram obtidos de análise de testes de bombeamento (de poços distribuídos na Região Administrativa 6, que engloba a região de estudo), enquanto $K$ foi obtido por experimentos de amostras utilizando permeâmetro. Os dados no trabalho de CORREAA (op cit) foram obtidos de análise de testes de bombeamento (de poços na área e entorno das bacias do Jacaré-Guaçu e Jacaré-Pepira), enquanto $K$ foi obtido diretamente da relação $K=$ $T / b$, sendo $b$ a espessura saturada do aqüífero.

Tabela 10 - Características hidrodinâmicas do Aqüífero Guarani na área de estudo, segundo DAEE (1974)

\begin{tabular}{l|c|c|c|c}
\hline Unidade Geológica & $K(\mathrm{~m} / \mathrm{d})$ & $T\left(\mathrm{~m}^{2} / \mathrm{d}\right)$ & $n(\%)$ & $S(-)$ \\
\hline \hline Formação Botucatu & 3,5 & 200 a 540 & 25 & $10^{-3}$ a $10^{-5}$ \\
Formação Pirambóia & 2 a 3 & 300 & 15 a 20 & $10^{-3}$ a $10^{-5}$ \\
\hline
\end{tabular}

Tabela 11 - Características hidrodinâmicas do Aqüífero Guarani, segundo CORRÊA (1995).

\begin{tabular}{l|c|c|c|c}
\hline $\begin{array}{l}\text { Característica } \\
\text { Hidrodinâmica }\end{array}$ & \multicolumn{1}{c}{ Máximo } & Mínimo & \multicolumn{1}{c}{ Média } & Desvio-padrão \\
\hline \hline $\mathrm{Q} / \mathrm{s}\left(\mathrm{m}^{3} / \mathrm{h} / \mathrm{m}\right)$ & 15,2 & 0,04 & 2,4 & 2,4 \\
$T\left(\mathrm{~m}^{2} / \mathrm{d}\right)$ & 663,0 & 17,0 & 118,2 & 113,5 \\
$K(\mathrm{~m} / \mathrm{d})$ & 4,3 & 0,2 & 0,8 & 0,8 \\
\hline
\end{tabular}


Tabela 12 - Características hidrodinâmicas do Aqüífero Guarani, segundo IPT (2003)

\begin{tabular}{l|c|c|c}
\hline Condições de Confinamento & \multicolumn{1}{c}{$T\left(\mathrm{~m}^{2} / \mathrm{d}\right)$} & $n(\%)$ & $\mathrm{Q} / \mathrm{s}\left(\mathrm{m}^{3} / \mathrm{h} / \mathrm{m}\right)$ \\
\hline \hline Livre & - & 20 & 0,15 a 10 \\
Confinado & 350 a 500 & - & 0,5 a 10 \\
\hline
\end{tabular}

\subsection{DADOS DE CAMPO}

A implementação do modelo estacionário requer conhecimento do nível estático (NE), de forma bem distribuída, do Aqüifero Guarani em diversos pontos da área de estudo, bem como, de sua estratigrafia local. Essas informações são importantes para estimar a relação rio-aqüifero que norteia o modelo conceitual, calibração e definição de condições de contorno do modelo numérico. Com esse propósito, foi realizada uma campanha de campo visando completar e avaliar a qualidade de dados de um conjunto de poços cadastrados, bem como, investigar características locais da drenagem na área das bacias.

Em relação aos poços, foi selecionado um conjunto de 170 unidades (Figura 19), contendo dados hidráulicos e estratigráficos mais confiáveis (Anexo A). Foram selecionados visando estimar a superfície potenciométrica para a região das duas bacias e seu entorno, bem como, fornecer dados sobre a estratigrafia local. Na escolha, foi considerada a necessidade de tomar dados bem distribuídos, alguns fora do limite das bacias, para investigar possíveis contribuições de fluxo lateral na área de estudo. A avaliação da qualidade desses dados e sua complementação se deram com uma campanha de medições de NE e coordenadas de posição de um número selecionado de poços desse conjunto. Ao tentar obter informações em áreas com maior escassez de dados, foi necessário incluir informação de poços mais antigos, obtendo-se um conjunto final de dados com idade média de doze anos. As medições de NE, contudo, se mostraram inadequadas ou até impraticáveis em diversos poços, quer pelo poço se encontrar em funcionamento, quer por não dispor de dispositivo para monitoramento (conduto para acesso ao nível d'água, Figura 21) ou esse dispositivo se encontrar em condições inadequadas de funcionamento. 


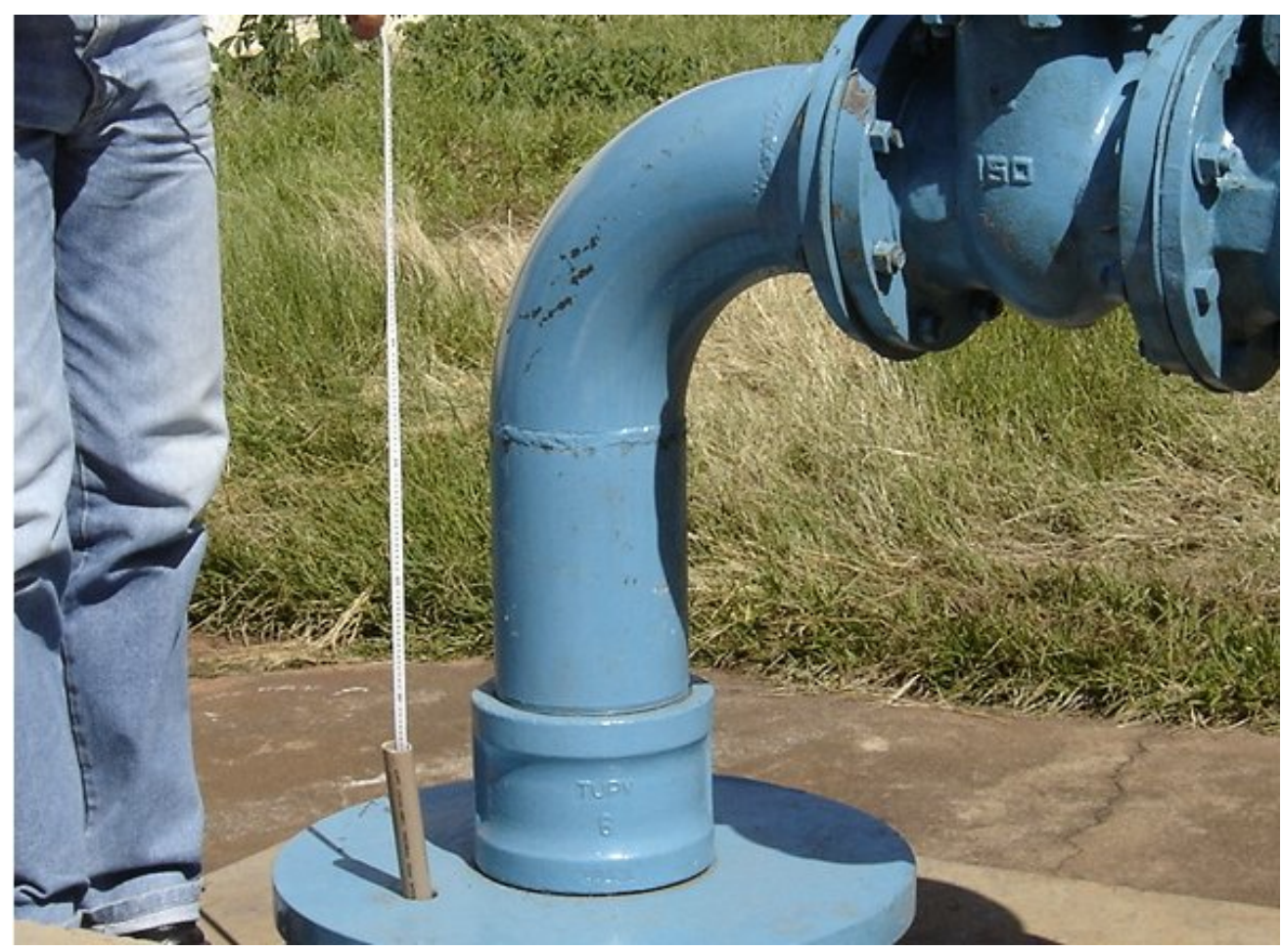

Figura 21 - Poço do $S A A E^{1}$ em Ibitinga, com dispositivo para monitoramento do nível d'água; cota topográfica $512 \mathrm{~m}$ e NE $426 \mathrm{~m}$, em 1995², fonte DAEE (1995)

Nos poços em atividade, era necessário agendar com o proprietário o desligamento do poço com antecedência de várias horas ou até mais de dia, o que dificultou a medição dos poços inicialmente pretendidos. Diante da baixa eficiência na inspeção dos NEs, o número de medições, previsto inicialmente em 28, foi reduzido para 15, nos municípios de Araraquara, Ibitinga e Itirapina. Dentre as medições, um terço foi realizado em poços desativados, que comumente se encontram em condições ruins de conservação e de difícil acesso à medição (Figura 22).

\footnotetext{
${ }^{1}$ SAAE - Serviço Autônomo de Água e Esgoto.

${ }^{2}$ A má condição do conduto de monitoramento neste poço, não permitiu que o medidor de nível chegasse até à superfície da água, não sendo possível determinar o NE em 2005.
} 

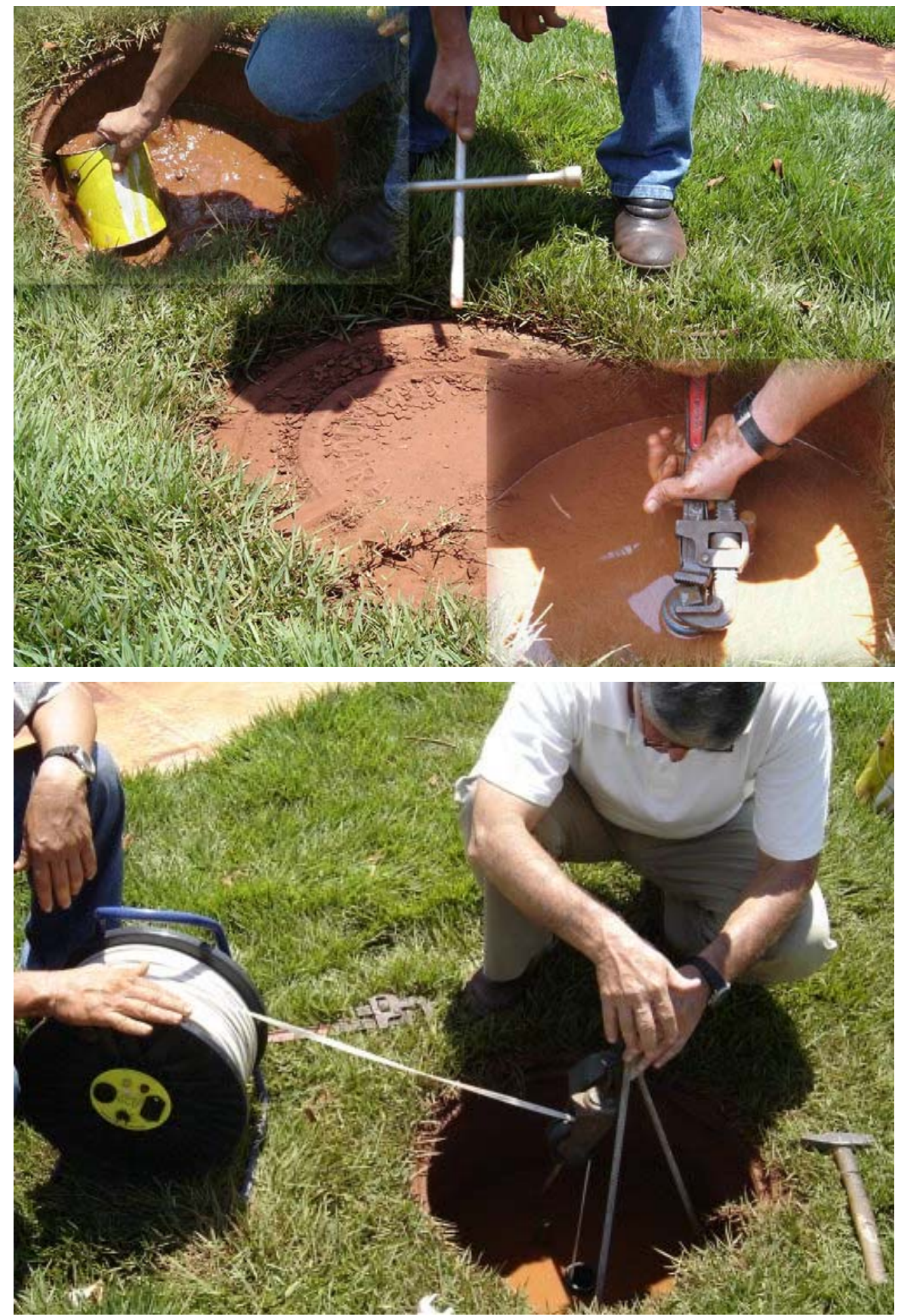

Figura 22 - Poço desativado na cidade de Araraquara com difícil acesso a medição do nível d'água; rebaixamento de 38 m do NE (1978 - 2005)

Apesar do número restrito de medições, foi possível identificar características importantes em relação aos dados de interesse na área de estudo: 
a) os níveis estáticos da parte montante da área das bacias, representados por poços em Itirapina, mostraram relativamente pequena variação num período aproximado de treze anos. De quatro poços pesquisados, os NEs atuais apresentaram rebaixamentos inferiores a 11 metros (poços posteriores a 1991) em relação aos níveis originais (Figura 23);

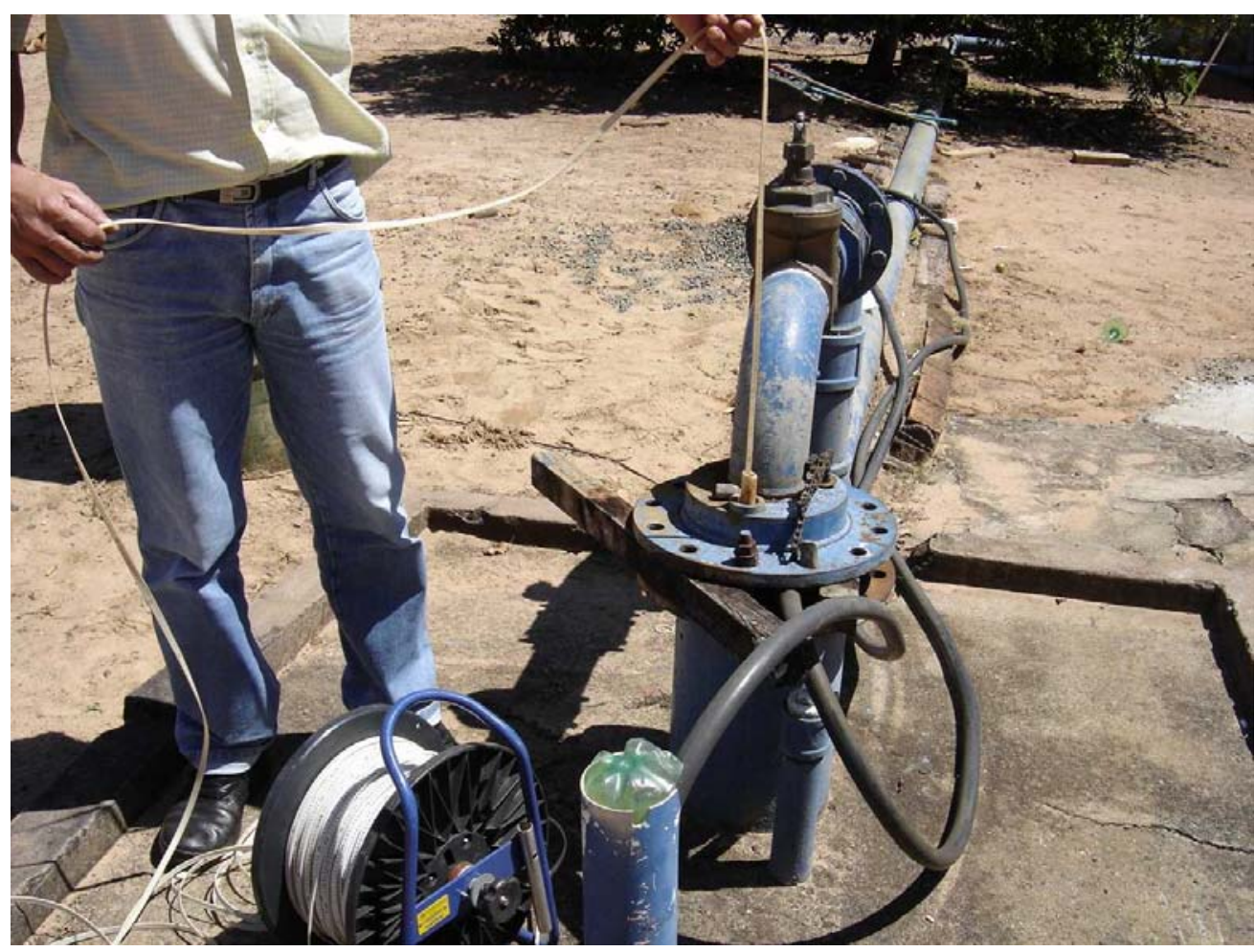

Figura 23 - Poço do SAAE em Itirapina; rebaixamento de 4,5 m do NE (1999 2005)

b) na parte próxima ao exutório das bacias, os NEs representados pelos poços de lbitinga mostraram proximidade com a cota dos lagos na área (aproximadamente $410 \mathrm{~m}$ ), formados pelo represamento do Rio Tietê na barragem de Ibitinga (Figura 21 e Figura 24);

c) nas regiões de grande concentração de poços, representadas pela região de Araraquara, foi observado um rebaixamento médio de $32 \mathrm{~m}$ entre os poços observados (NE de referência quando da construção dos poços). Os dois maiores rebaixamentos observados foram de $39 \mathrm{~m}$, e $50 \mathrm{~m}$, respectivamente, em um poço desativado, construído em 1978, e próximo a poços mais recentes de industria cervejeira (Figura 22) e em um poço desativado na área da penitenciaria 
municipal, construido em 1990. Este fato indica que nessas regiões é difícil determinar o NE, devido à interferência conjunta da explotação de poços na região. Em regiões com essa característica mais generalizada, portanto, é pouco provável se estabelecer um nível potenciométrico representativo.

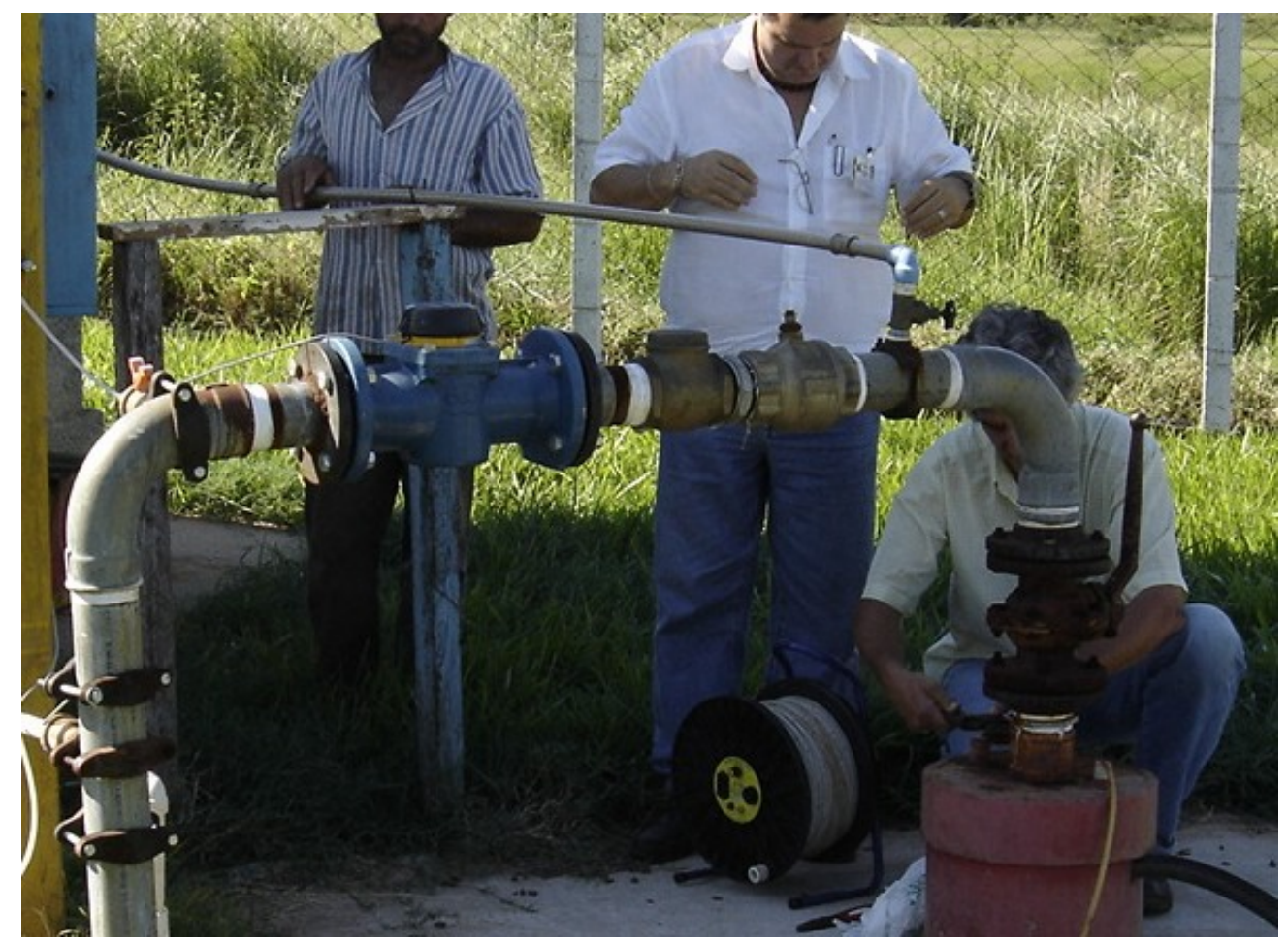

Figura 24 - Poço do SAAE em Cambaratiba, distrito de Ibitinga; cota topográfica 450 m e NE 424 m, em 2005.

d) de modo geral, o NE no Aqüífero Guarani pode estar em desacordo com poços vizinhos por influências locais, p.ex., por heterogeneidade estratigráfica, sobretudo na região de arenito/basalto intercalados (observado na região de Itirapina), e por contribuição do aqüífero Bauru-basaltos, quando o poço que capta água preferencialmente do Guarani possui filtro também nessas formações superiores (observado na região de lbitinga);

e) os dados de coordenadas de poços (em UTM), comumente apresentam desvios que podem ser significativos, sobretudo se em áreas de transição de formação geológica. Medições refeitas nessa campanha identificaram diferenças de posicionamento de até $2100 \mathrm{~m}$, em relação aos respectivos dados cadastrais de poços. 


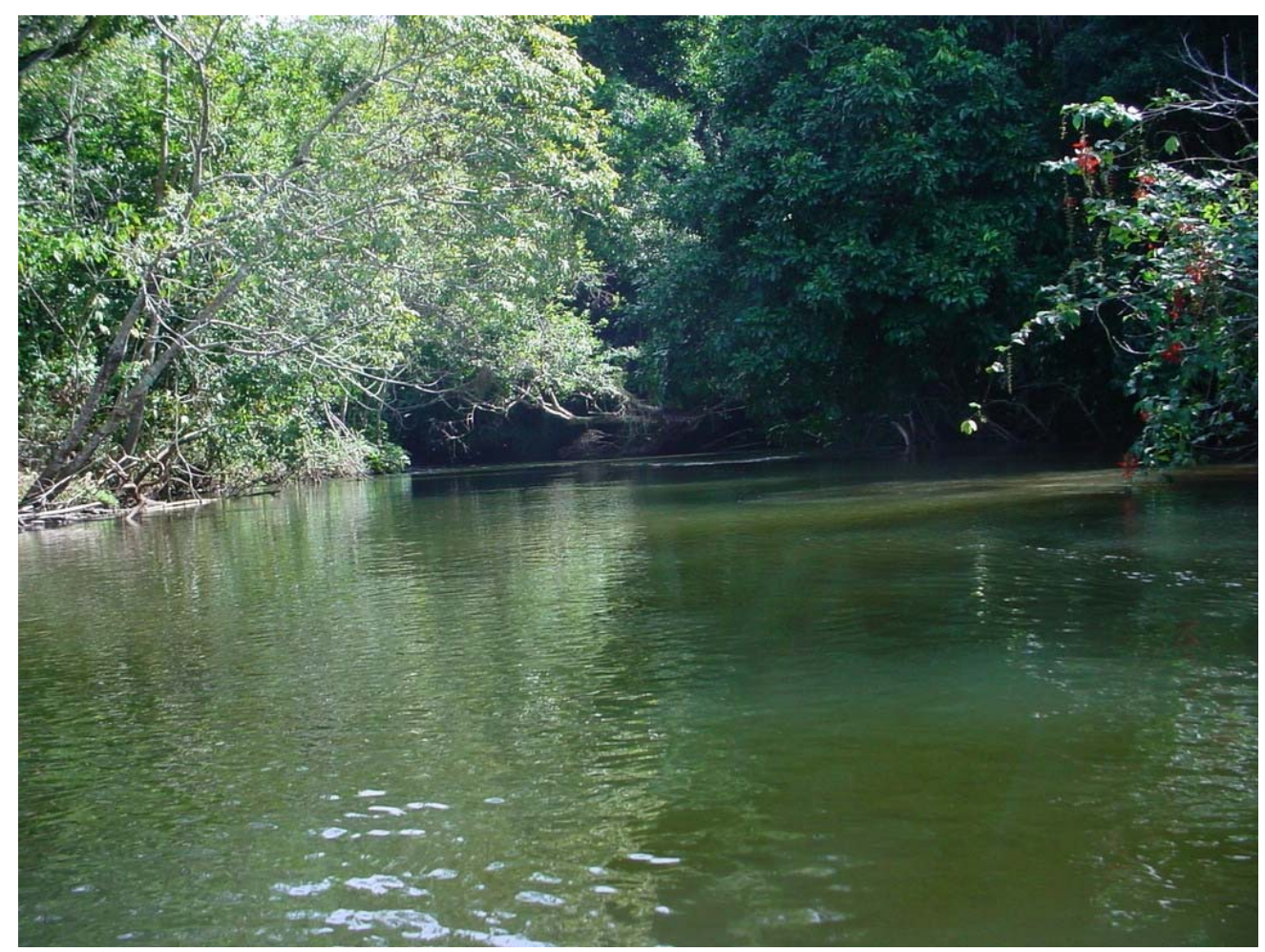

Figura 25 - Início do Rio Jacaré-Guaçu, no encontro dos ribeirões do Lobo e do Feijão, em região de Formação Serra Geral.

Em relação à drenagem, foram observados os leitos dos rios principais e de alguns tributários, verificando, em campo, como ocorrem os basaltos referenciados nos mapas geológicos e em trabalhos correlatos. Dificilmente visíveis no Rio Jacaré-Guaçu, por já iniciar com profundidade (Figura 25), os basaltos ao longo do leito foram observados em alguns de seus tributários, em área de mesma característica geológica (Figura 26) e no Rio Jacaré-Pepira, na cidade de Brotas (Figura 27). 

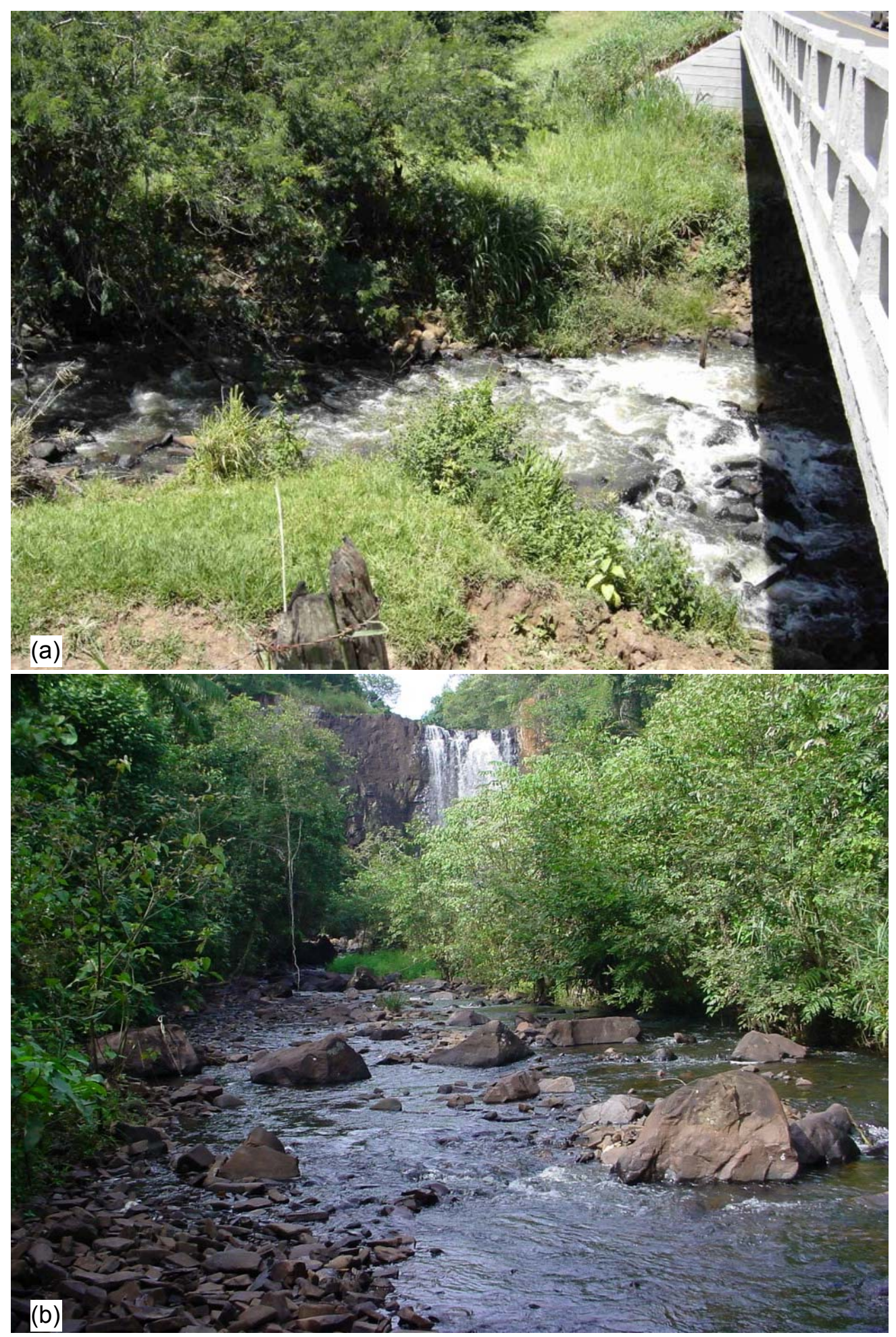

Figura 26 - Tributários do Rio Jacaré-Guaçu em região de Formação Serra Geral: (a) Ribeirão Bonito, distante 7 km do Rio Jacaré-Guaçu; (b) queda d'água no Ribeirão do Lobo, distante 5 km do Rio Jacaré-Guaçu. 
Esses afloramentos ao longo dos leitos se constituem de basaltos, geralmente fraturados em blocos, com diferente distribuição e formas, característicos das regiões de basalto. Nas regiões de contatos de diferentes formações (Serra Geral, Botucatu/Pirambóia), o leito acompanha a direção de fraqueza, caracterizada pelo contato litológico.

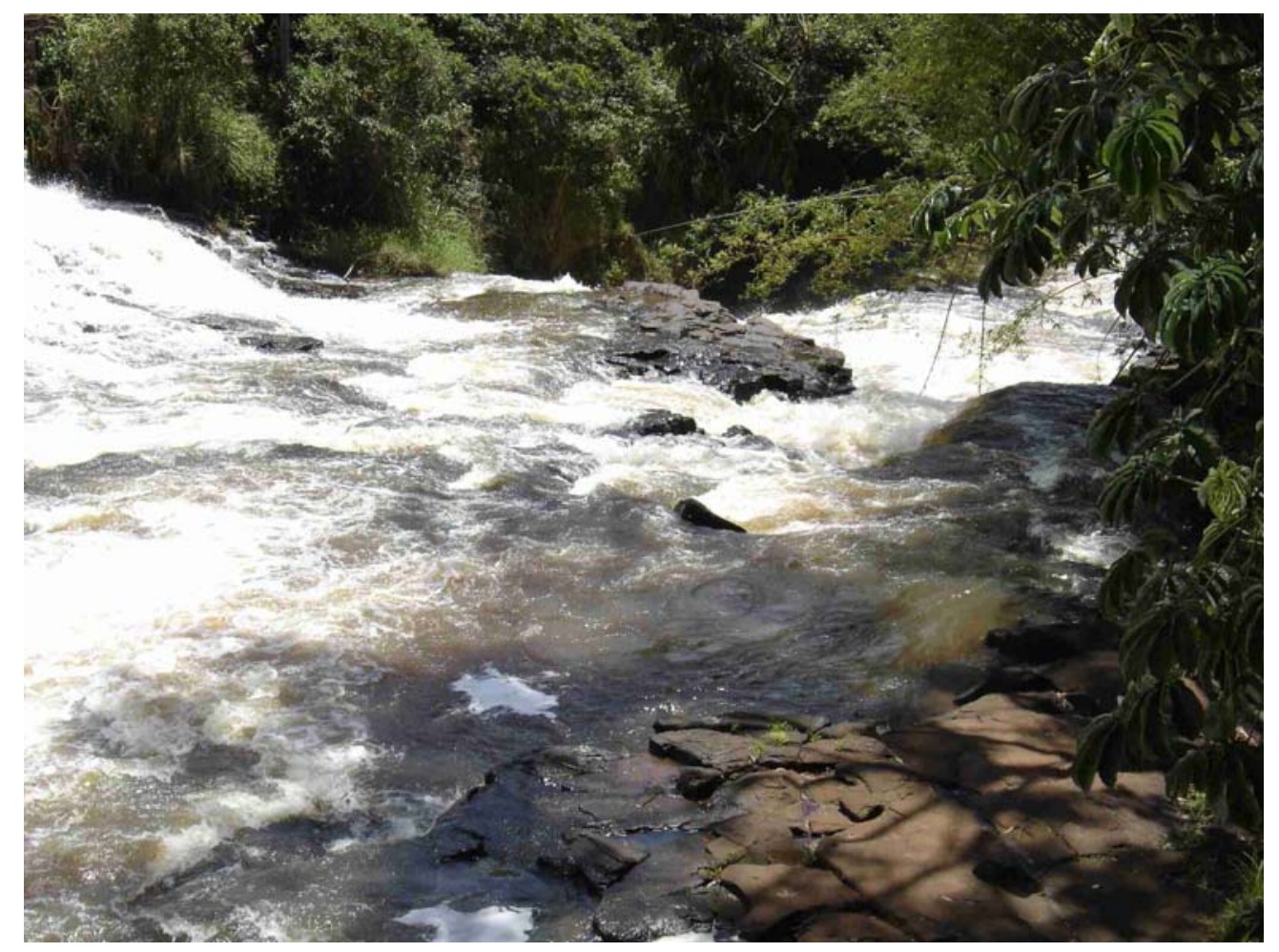

Figura 27 - Rio Jacaré-Pepira, na cidade de Brotas, em região de Formação Serra Geral 


\section{METODOLOGIA}

\subsection{MODELO CONCEITUAL}

Quantificar quaisquer dos processos hidrológicos ocorrentes nas bacias requer o uso de simplificações, que são comumente estabelecidas nos modelos conceituais. Sua utilização é necessária à implementação do modelo numérico. $\mathrm{O}$ modelo conceitual proposto para as bacias objeto de estudo é direcionado à construção de modelo numérico de fluxo subterrâneo, bi-dimensional horizontal, heterogêneo e isotrópico, visando, sobretudo, estimar a recarga do Aqüífero Guarani. Todas as informações obtidas, referentes à área de estudo, visaram dar subsídios para estabelecer as unidades hidroestratigráficas, o balanço hídrico e o sistema de fluxo do modelo conceitual do aqüífero. A seguir são discriminadas as simplificações consideradas pelo modelo.

\section{A. Unidade hidroestratigráfica}

O Aqüífero Guarani, na área de estudo, delimitado pelo conjunto das bacias do Jacaré-Guaçu e Jacaré-Pepira foi considerado como uma unidade hidroestratigráfica, possuindo regiões individualizadas de recarga, descarga de base e fluxo lateral, limitada inferiormente pela base da Formação Pirambóia e superiormente pelo topo das Formações Botucatu/Pirambóia. Foi considerado, inicialmente, um valor único para a condutividade hidráulica, posteriormente, distribuído espacialmente no processo de calibração do modelo. Estas simplificações são baseadas nas seguintes constatações:

i - semelhança hidrogeológica entre a Formação Botucatu e maior parte da Formação Pirambóia;

ii - isotropia do Aqüífero Guarani, quando considerado regionalmente; 
iii - confluência entre os dois rios principais na direção do Rio Tietê, com fortes características de proximidade e paralelismo entre si, bem como, semelhança topográfica e geomorfológica entre as duas bacias;

iv - semelhança de níveis piezométricos nas bacias - principalmente nas respectivas partes jusantes - , de parâmetros hidrodinâmicos e estratigrafia (obtidos de poços no Guarani em ambas as bacias).

\section{B. Recarga}

Inicialmente, foi estabelecida uma simplificação geral do sistema de recarga, considerando-se apenas dois tipos, as que chegam diretamente ao aqüífero e as que passam primeiramente através de estruturas sobrejacentes ao aqüífero, respectivamente, as recargas direta e indireta (Figura 28). O sistema de recarga proposto considerou uma interação entre os aqüíferos Guarani e Bauru-basaltos que prevê a recarga indireta do Guarani por dois modos: infiltração interna, diretamente do aqüífero Bauru-basaltos ao Guarani, e infiltração externa do escoamento do aqüífero Bauru-basaltos ao Guarani (Figura 29)

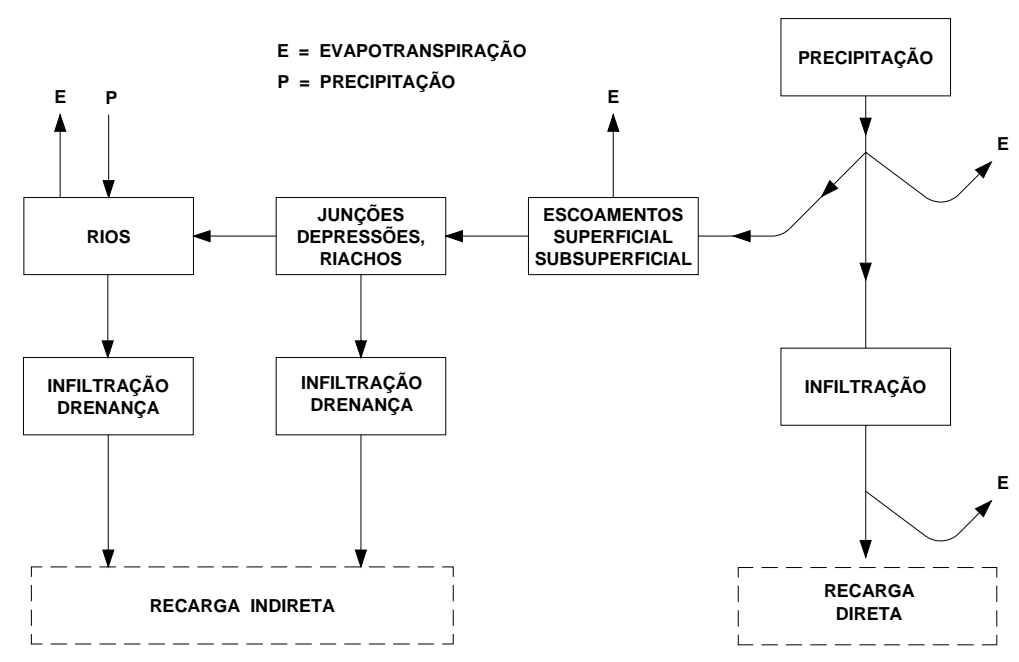

Figura 28 - Mecanismos de recarga do modelo conceitual

Foram consideradas seis zonas de recarga, correspondentes às respectivas estruturas geológicas existentes na área das bacias: formações Adamantina, Itaqueri e Serra Geral, Sedimentos da Serra de São Carlos, formações Botucatu/Pirambóia e arenito/basalto intercalados (Figura 13). As quatro primeiras 
estruturas (ou regiões) são onde o aqüífero é semiconfinado (recarga indireta). A região denominada de arenito/basalto intercalados é formada pelas formações Botucatu/Pirambóia aflorantes, porém com característica diferenciada de recarga. Essa diferenciação, em relação à região denominada como Botucatu/Pirambóia, é atribuída à grande incidência de áreas de transição entre as duas estruturas: basaltos e formações Botucatu/Pirambóia, possibilitando infiltração diferenciada na interface dos dois tipos de estrutura.

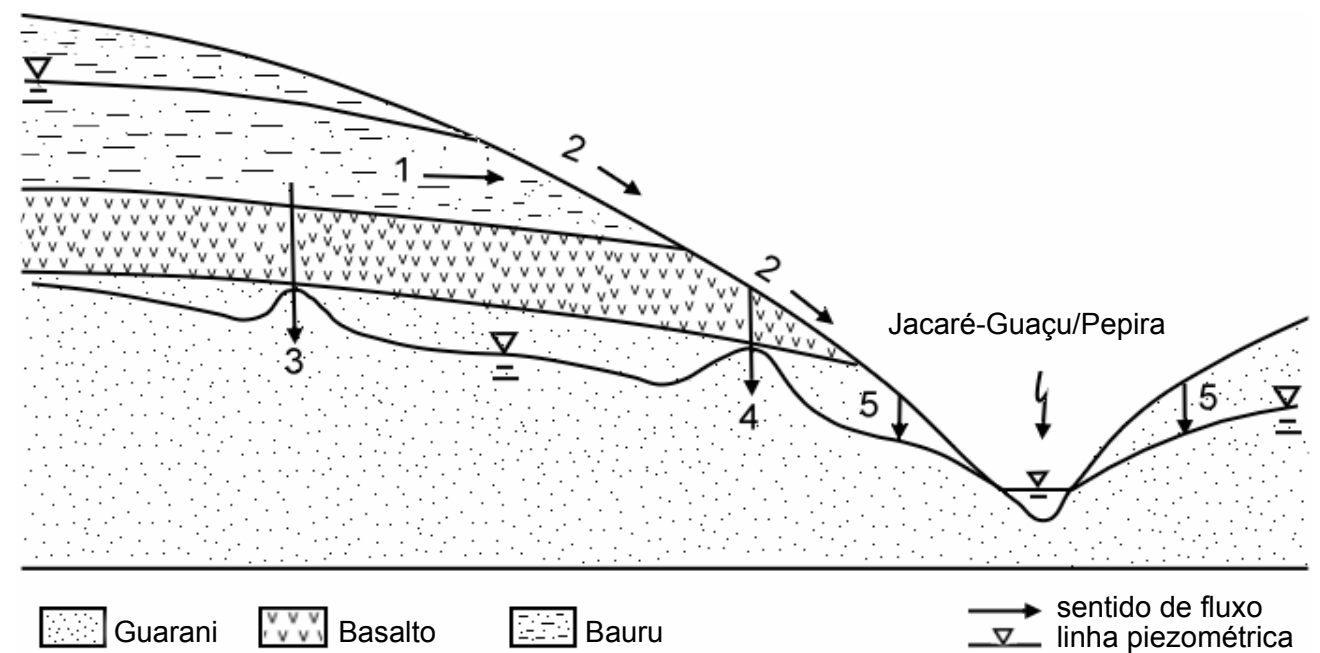

Figura 29 - Mecanismos de recarga no Aqüífero Guarani, proveniente de sistemas aqüíferos. 1. Percolação do aqüífero de formações do Grupo Bauru e equivalentes; 2. Escoamento externo ao aqüífero Bauru-basaltos; 3. Recarga interna por infiltração proveniente do aqüífero Bauru-basaltos; 4 . Recarga externa

por infiltração proveniente do aqüífero Bauru-basaltos; 5. Recarga direta

A distribuição de zonas de recarga utilizada é baseada no argumento de que a localização das estruturas geológicas está associada, na área das bacias, a características que influenciam sobremodo a recarga, como a pluviosidade, tipo de solo e gradiente topográfico.

\section{Descarga}

O fluxo de base, proveniente do Guarani, acontece ao longo de toda a drenagem das bacias, nas regiões onde existe interação rio-aqüífero. Essa interação pode existir mesmo em regiões de aqüífero semiconfinado, desde que exista proximidade entre o nível potenciométrico do Guarani e o nível do rio. Esta condição é verificada principalmente na região próxima aos exutórios das bacias, 
onde o aqüífero é confinado pelos basaltos da Formação Serra Geral, e níveis estáticos de poços apresentam cotas próximas às dos lagos das represas da região.

A descarga total $\left(Q_{t}\right)$ ao longo dos rios principais é composta dos escoamentos superficial $\left(Q_{s}\right)$ e de base total $\left(Q_{b t}\right)$. $Q_{b t}$ é composto do somatório dos escoamentos de base advindos do Aqüífero Guarani $\left(Q_{b G}\right)$ e do sistema aqüífero Bauru-basaltos $\left(Q_{b B / b}\right)$. O modelo numérico bi-dimensional horizontal necessita, para sua calibração, dos escoamentos ao longo dos rios principais, provenientes apenas do Guarani $\left(Q_{b G}\right)$,

$$
Q_{b G}=Q_{b t}-Q_{b B / b}
$$

Neste trabalho, a estimativa de $Q_{b t}$ foi obtida diretamente da separação de base de $Q_{t}$. As estimativas de vazões de base foram realizadas aplicando-se o método de separação de escoamento de base, Recursive Digital Filter (NATHAN e McMAHON, 1990). $Q_{b B / b}$ foi obtida do somatório das contribuições das vazões de base específica de bacias-referência das formações do Bauru. A vazão de base específica $\left(Q_{b}{ }^{\prime}\right)$ foi definida como:

$$
Q_{b}{ }^{\prime}=Q_{b} / A,
$$

na qual $Q_{b}$ é o escoamento de base da bacia-referência de área de drenagem $A$. Foi determinada a vazão de base específica em bacias-referência características de cada uma das formações ou estruturas: Formação Adamantina ( $\left.Q_{b}{ }^{\prime}{ }_{A D A}\right)$, Formação Itaqueri $\left(Q_{b}{ }^{\prime}{ }_{\text {TAA }}\right)$, e Sedimentos da Serra de São Carlos $\left(Q_{b}{ }^{\prime}{ }_{S S C}\right)$. Essas bacias foram escolhidas segundo os critérios de representatividade do escoamento em cada tipo de formação ou estrutura, e o de possuir respectivos dados fluviométricos (Figura 30). Assim,

$$
Q_{b G}=Q_{b t}-\left(A_{A D A} Q_{b}{ }_{A D A}+A_{I T A} Q_{b}^{\prime}{ }_{I T A}+A_{S S C} Q_{b}^{\prime}{ }^{\prime} S C\right)
$$

na qual $A_{A D A}, A_{I T A}$ e $A_{S S A}$ são as áreas, respectivamente das três formações, contidas na área de drenagem, correspondentes ao ponto de interesse no rio principal onde se estima o valor de $Q_{b G}$. Foram selecionados seis pontos ao longo 
do Rio Jacaré-Guaçu e dois ao longo do Rio Jacaré-Pepira, correspondentes às respectivas estações fluviométricas.

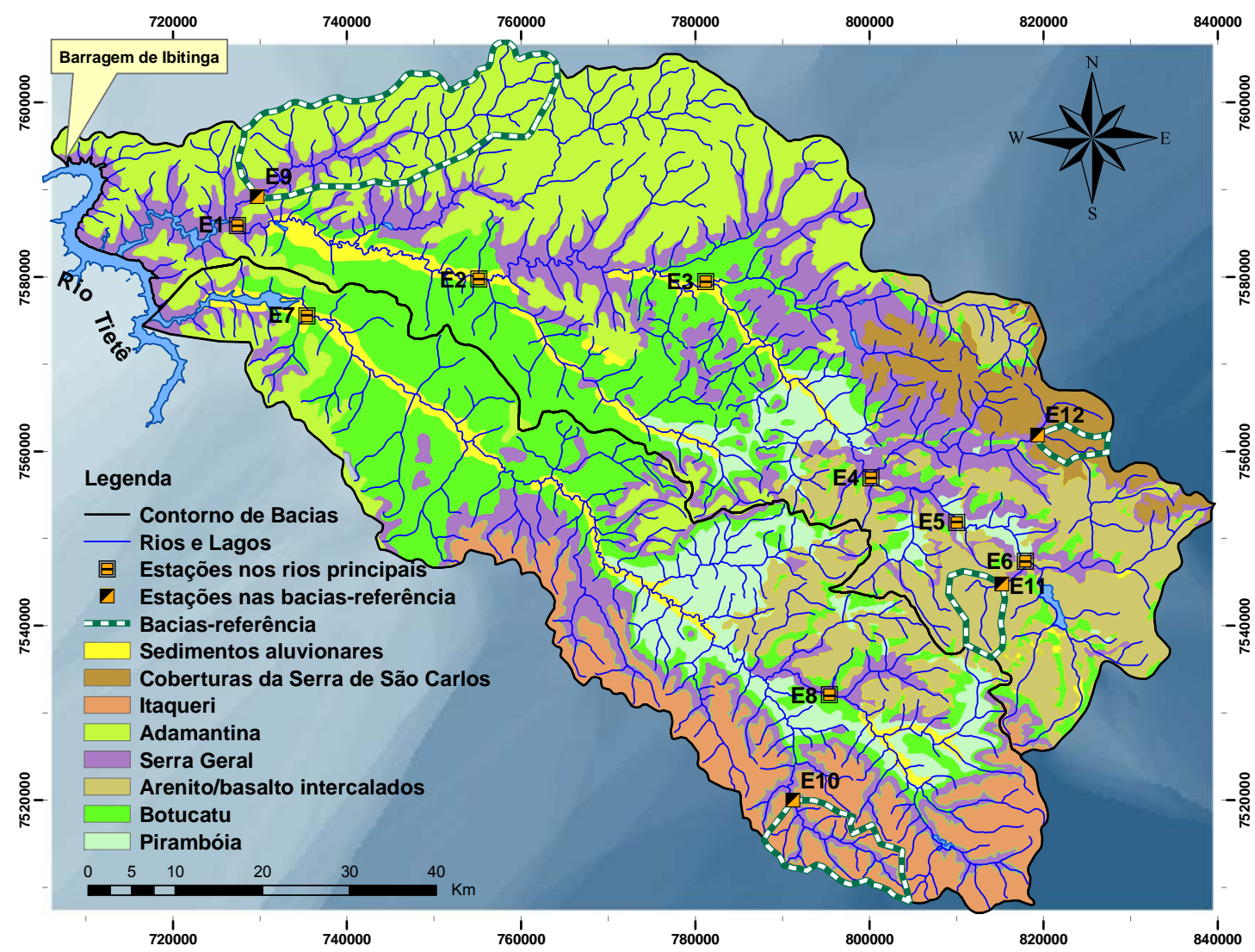

Figura 30 - Estações fluviométricas nos rios principais (E1 a E8) e nos rios das bacias-referência (E9 a E12), utilizadas na estimativa de fluxo de base do Aqüífero Guarani

Apenas para as estações fluviométricas localizadas na região montante da bacia do Jacaré-Guaçu (estações E4, E5 e E6), foi adotado procedimento diferente para estimar os escoamentos de base:

$$
\begin{aligned}
& Q_{b G}=Q_{b}{ }^{\prime}{ }_{B O T} \cdot Q_{t} \cdot \frac{A_{B O T}}{A}, \text { no qual } \\
& Q_{b B O T}{ }^{\prime}=\left(\frac{Q_{b}}{Q_{t}}\right)_{B O T}
\end{aligned}
$$


é a vazão de base específica, relação entre as vazões de base e total, da baciareferência de Formação Botucatu, e $\frac{A_{B O T}}{A}$ é a relação entre a área da Formação Botucatu e de drenagem, correspondente ao ponto de interesse no rio principal onde se estima o valor de $Q_{b G}$. Este procedimento foi adotado por levar a resultados mais consistentes, que o método anterior, em relação ao conjunto dos escoamentos de base obtidos das demais estações fluviométricas. Tal comportamento pode estar associado à presença significativamente maior, nesta região, da Formação Botucatu em relação às formações do sistema Baurubasaltos (média de $80 \%$ nas sub-bacias correspondentes às três estações).

Os valores de escoamento de base, estimados nos locais das estações fluviométricas ao longo dos rios principais, são apresentados na seção 4.3.4.

Um outro tipo de descarga, mais comumente referido como escoamento ou fluxo lateral, representa a interação hidráulica entre o aqüífero da área de estudo e o aqüífero de seu entorno (fluxo subterrâneo entre bacias). Neste trabalho, essa contribuição foi estimada inicialmente a partir das estimativas dos gradientes hidráulicos e da condutividade para a área de estudo e seu entorno, aplicando-se a Lei de Darcy. A descrição dessa estimativa é feita na seção 4.3.3. Posteriormente, essa estimativa foi ajustada numericamente durante o processo de calibração.

\subsection{OBTENÇÃO E PROCESSAMENTO DE DADOS EM SIG}

O SIG tem sido utilizado como a forma mais adequada de gerenciamento de grandes quantidades de dados hidrológicos, por dispor de bons recursos de armazenamento, processamento e visualização. Ao mesmo tempo, dispõe de possibilidades de exportação e importação de arquivos em diversos formatos, que permitem compartilhar dados e recursos entre diferentes programas. Neste trabalho, essa interatividade se dá entre o sistema Arcview (ESRI, 2002) e o Simulador de Processos em Aqüíferos - SPA (WENDLAND, 2003), o que permitiu fornecer ao modelo numérico todos os dados georeferenciados necessários, incluindo-se dados pesquisados e processados. Entretanto, o SPA utiliza dados 
de entrada tipo ASCII, em uma formatação específica, não suportada pelo Arcview. Devido à grande quantidade de dados a serem transferidos do SIG ao SPA, e para manter a interatividade entre os programas, foi desenvolvido um aplicativo, em Visual Basic e ambiente ArcGIS, para exportar de forma automática os dados no formato SPA. O código fonte, bem como, as instruções de instalação e utilização do aplicativo encontram-se no Apêndice B.

\subsubsection{Dados armazenados}

Após pesquisa bibliográfica sobra a área de estudo, foram identificadas as fontes de dados tendo como origem principalmente trabalhos do meio acadêmico e instituições governamentais de assistência e pesquisa. Neste trabalho, os dados foram digitalizados, georeferenciados e classificados nos seguintes grupos, utilizado o sistema Arcview, como discriminado a seguir.

\section{A. Características superficiais das bacias}

Foram utilizados os seguintes mapas digitalizados (dados vetoriais) em escala 1:250. 000 (IPT, 2003) e em escala 1:100. 000 (CORRÊA, 1995):

i. contornos das bacias hidrográficas dos rios Jacaré-Guaçu e JacaréPepira;

ii. fisiografia - planialtimetria, com curvas de nível espaçadas de $50 \mathrm{~m}$;

iii. hidrografia - sem cotas altimétricas, apenas coordenadas $x, y$ (planimetria);

iv. geologia de superfície

Os dados de poços incluem informações construtivas, hidráulicas e hidrogeológicas, enquanto os dados fluviométricos discriminam características hidrológicas e de funcionamento da estação. Tanto os dados de poços como de estações fluviométricas foram obtidos dos acervos do DAEE e ANA.

B. Geologia de subsuperfície 
Foram utilizados os seguintes mapas digitalizados (dados vetoriais) em escala 1:100.000 (CORRÊA, 1995):

i. contornos estruturais de base e isópacas da Formação Pirambóia;

ii. contornos estruturais de base e isópacas da Formação Botucatu.

iii. isópacas da Formação Serra Geral

\subsubsection{Dados processados}

No processamento foram utilizadas duas técnicas com finalidades distintas: a de interpolação de dados no domínio das bacias, e a de operação de rasters. Na primeira, optou-se sempre pelo método de krigagem ordinária e na segunda, foram utilizados os três grupos de operadores: aritimético, booleano e relacional. Os arquivos tipo raster foram obtidos, convertendo-se os dados vetoriais, ou os interpolando por krigagem, ou por meio de operação entre rasters já existentes. $O$ grid - espaçamento $\Delta x, \Delta y$, em plano horizontal, dos valores interpolados nos rasters - foi padronizado em $400 \times 400 \mathrm{~m}$. Este valor foi adotado por ser considerado adequado para representar as variações dos diversos conjuntos de dados, e por não elevar significativamente o esforço computacional. A unidade de todos os dados representando cotas foi em metros sobre o nível médio do mar (m.s.n.m).

\subsubsection{Fisiografia da bacia e domínio do aqüífero}

Esses dados foram gerados com os objetivos de definir o domínio do aqüífero para a implementação do modelo numérico e o de estimar as cotas das formações que compõem o Aqüífero Guarani. Os dados processados são discriminados a seguir.

\section{A. Planialtimetria}

Interpolações de cotas planialtimétricas, gerando-se o modelo digital do terreno (Figura 31), arquivo tipo raster com valores de cotas planialtimétricas (Ra) 
que variaram de 408 a 1100 m, com declividade média de 2,6\%. Estas cotas foram utilizados na atribuição das cargas ao longo dos rios e no processo de correção das cotas estimadas de topo e base do aqüífero.

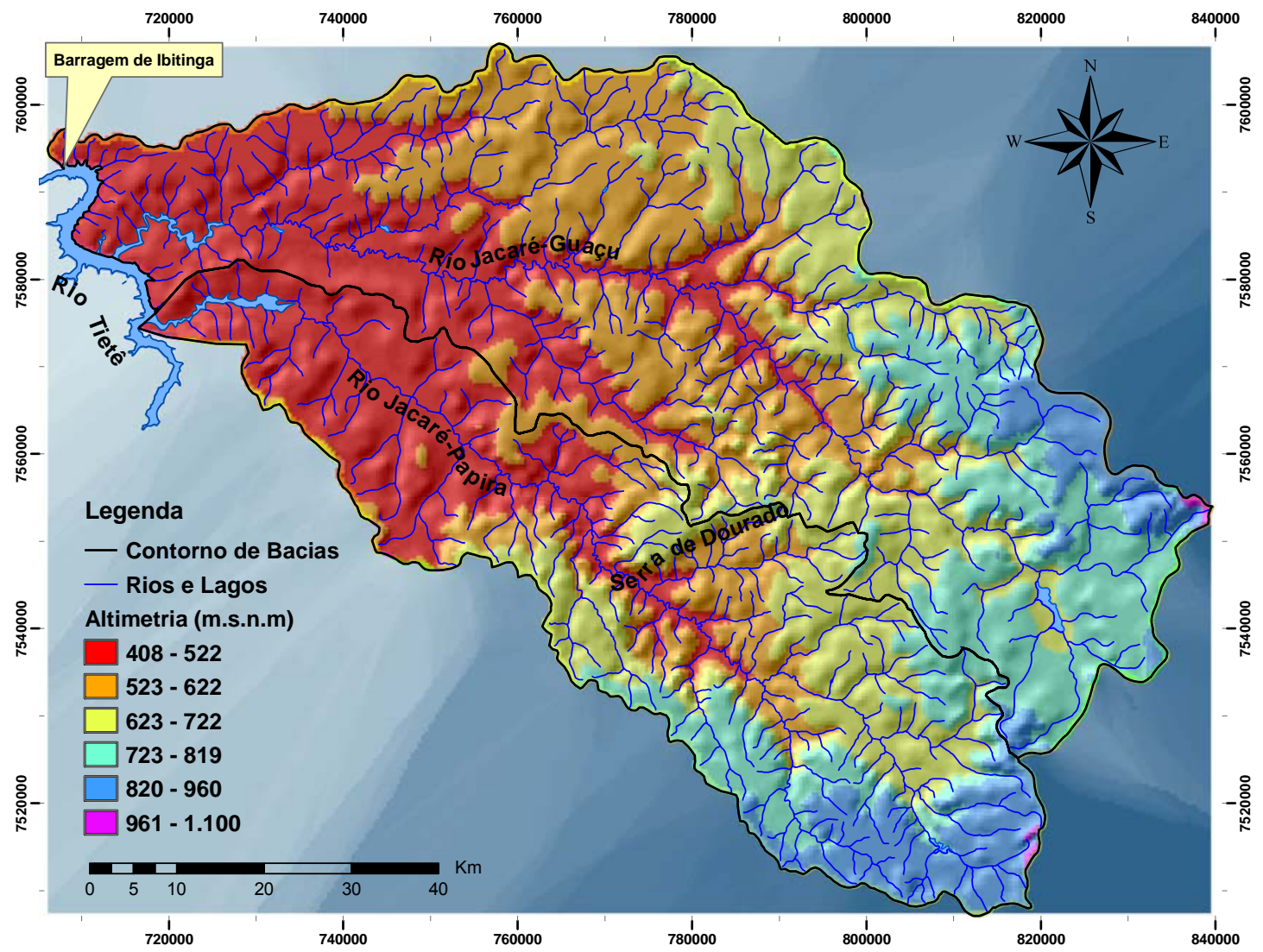

Figura 31 - Modelo digital de superfície das Bacias do Jacaré-Guaçu e Jacaré-

Pepira

\section{B. Geometria subterrânea}

Nesta etapa são descritos os passos realizados para a geração dos dados de base, topo e espessura do Aqüífero Guarani.

i. Interpolação dos dados vetoriais e geração dos respectivos rasters de conjunto de valores R1, R2 e R3: contorno estrutural de base da Formação Pirambóia (R1), isópacas da Formação Pirambóia (R2) e isópacas da Formação Botucatu (R3).

ii. Geração das cotas do topo do aqüífero (R4) a partir da soma dos valores dos três conjuntos anteriores $(R 4=R 1+R 2+R 3)$.

iii. Geração das cotas de topo da Formação Pirambóia (R5) a partir da soma dos dados de R1 e R2, R5 = R1 + R2. 
iv. Primeira correção dos dados de topo do aqüífero (R6), atribuindo-se a R6 os valores de R4, exceto onde a a Formação Pirambóia é aflorante, atribuindo-se os valores de R5:

$\mathrm{R} 6=\left\{\begin{array}{l}\mathrm{R} 4, \text { para região de Pirambóia não aflorante } \\ \text { R5, para região de Pirambóia aflorante }\end{array}\right.$, topo do Guarani.

v. Segunda correção dos dados de topo (R7) e correção dos dados de base (R8) do aqüífero, comparando-se os dados de topo (R6) com a altimetria (Ra).

As regiões de cota de topo $(\mathrm{R} 6)$, maiores que as cotas altimétricas, foram corrigidas por rebaixamento das respectivas cotas de topo (R6) e de base (R1), mantendo-se a espessura do aqüífero. Isso se deve ao fato de que, entre os conjuntos iniciais de dados (R1, R2 e R3), o de maior incerteza é o R1 (contorno estrutural de base da Formação Pirambóia), pois sua determinação está condicionada a informações de poços totalmente penetrantes no aqüífero. Assim, foram usadas as seguintes condições para gerar os dados finais de topo (R7) e de base (R8) do aqüífero:

$$
\begin{aligned}
& R 7=\left\{\begin{array}{l}
R 6, \text { para } R 6 \leq R a \\
R 6-(R 6-R a), \text { para } R 6>R a
\end{array} \quad\right. \text {, topo do aqüífero (Figura 32a), e } \\
& R 8=\left\{\begin{array}{l}
R 1, \text { para } R 6 \leq R a \\
R 1-(R 6-R a), \text { para } R 6>R a
\end{array}\right. \text {, base do aqüífero (Figura 32b). }
\end{aligned}
$$

vi. Geração dos dados de espessura do aqüífero (R9), a partir dos dados corrigidos de base e topo, R9 = R7 - R8 (Figura 32).

O aquifero apresenta um desnível de aproximadamente $660 \mathrm{~m}$, no sentido SE-NW, em concordância com os achados de CORRÊA (1995). 
(a)

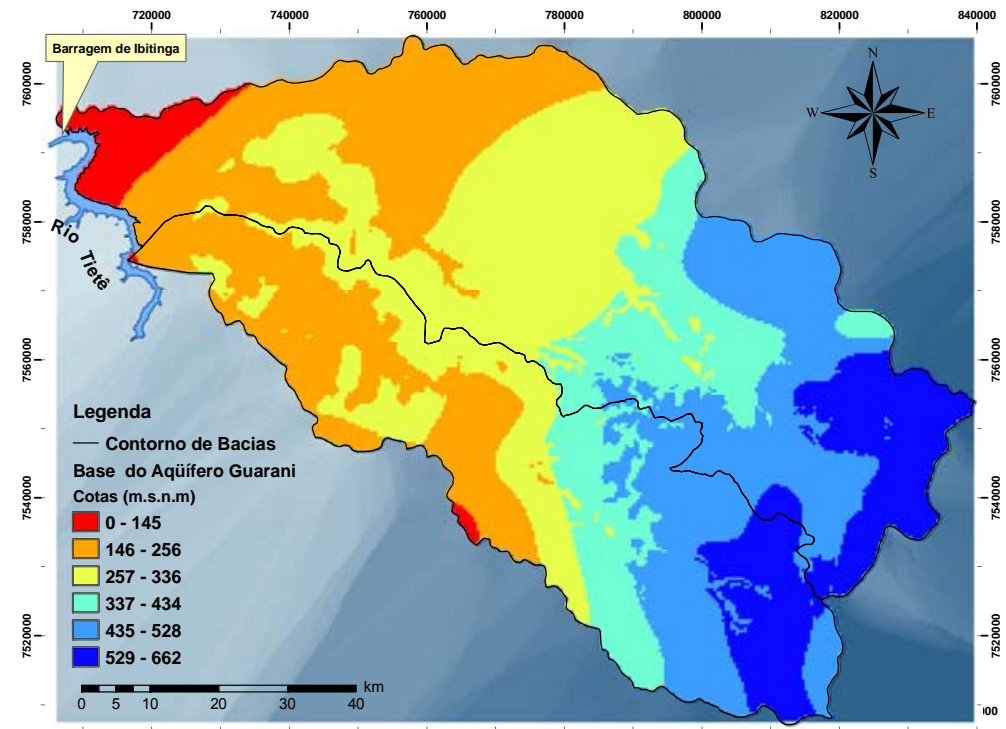

(b)

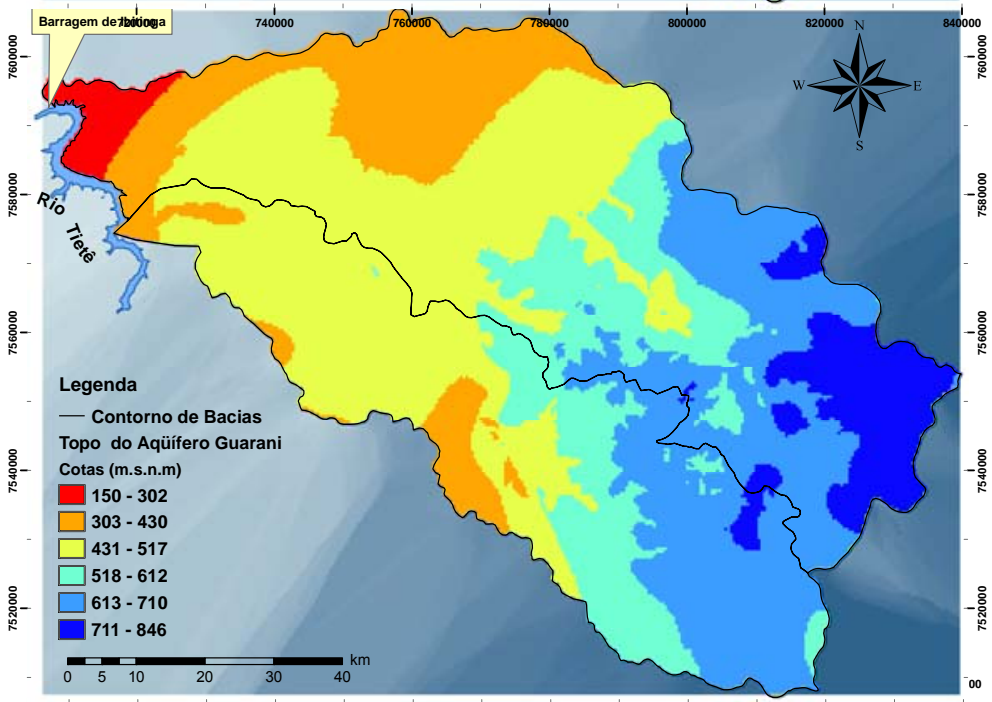

(c)

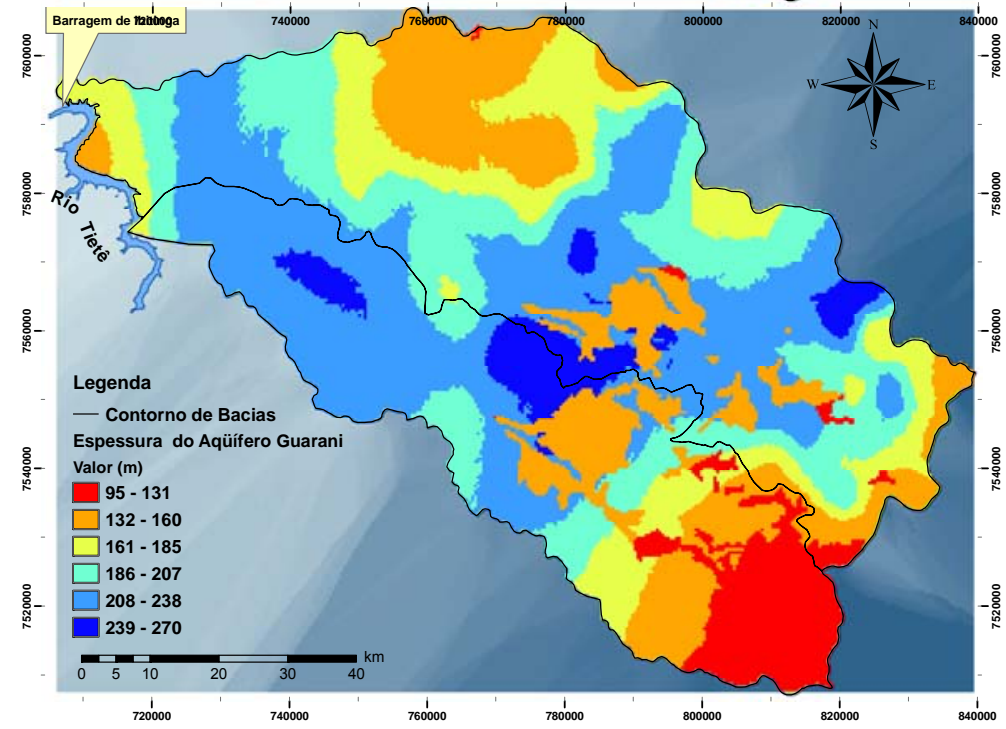

Figura 32 - Cotas de base e topo (em m.s.n.m) e espessura do Aqüífero Guarani (em $\mathrm{m})$, respectivamente (a), (b) e (c) 
A espessura do aqüífero (95 a 270 m) obtida para a área das bacias possui valor médio de $187 \mathrm{~m}$ com um desvio-padrão de $36 \mathrm{~m}$. Esse valor é inferior ao estimado para o Aqüífero Guarani como um todo $(250 \mathrm{~m})$, nos trabalhos de ROCHA (1997) e ARAÚJO et al. (1999), estando consistente com os valores estimados da espessura do aqüífero para a área de estudo por CORREAA (1995), (150 a $250 \mathrm{~m}$ ). A amplitude maior entre as espessuras obtidas e as encontradas por CORRÊA (1995) é justificada pela avaliação pontual de dados litoestratigraficos de poços, no referido trabalho. As espessuras médias de $191 \mathrm{~m}$, obtidas nas regiões de aqüífero livre, e 183 nas regiões de aqüífero confinado, não concordam com a expectativa de aqüífero mais espesso nas áreas confinadas, expectativa essa, atribuída provavelmente à ocorrência, nessas regiões, de poços com maior penetração no aqüífero.

As cotas de base e topo e espessura mostram, em geral, variações comuns ao longo do mergulho do aqüífero, que corroboram com o tratamento comum do aqüífero nos domínios das bacias.

\subsubsection{Superfície potenciométrica}

A estimativa da superfície potenciométrica para a região e seu entorno tem os objetivos de estudar o fluxo subterrâneo entre bacias e a interação rio-aqüífero. Para isso, foram interpolados dados de nível estático de 170 poços cadastrados na região (Figura 33). Para a área das duas bacias, o gradiente médio obtido é de 0,5\% e os valores variam de 0,01 a $3 \%$, com desvio-padrão de $0,3 \%$. A tendência do desnível preferencial, no sentido SE-NW, concordam com os achados nos trabalhos de DAEE (1974) e (CORRÊA, 1995)

Da distribuição dos contornos dos níveis piezométricos, observa-se uma tendência a um fluxo distinto entre bacias, apenas na parte montante da área de estudo. Nesta, observa-se tendência de fluxo lateral através do contorno, a sulsudeste da bacia do Jacaré-Pepira e a leste da bacia do Jacaré-Guaçu. A localização destes fluxos coincide com os achados de CORRÊA, 1995. Entretanto, não foram identificados fluxos laterais significativos nas direções N-S das duas bacias estudadas, como indicado pelo referido autor. 


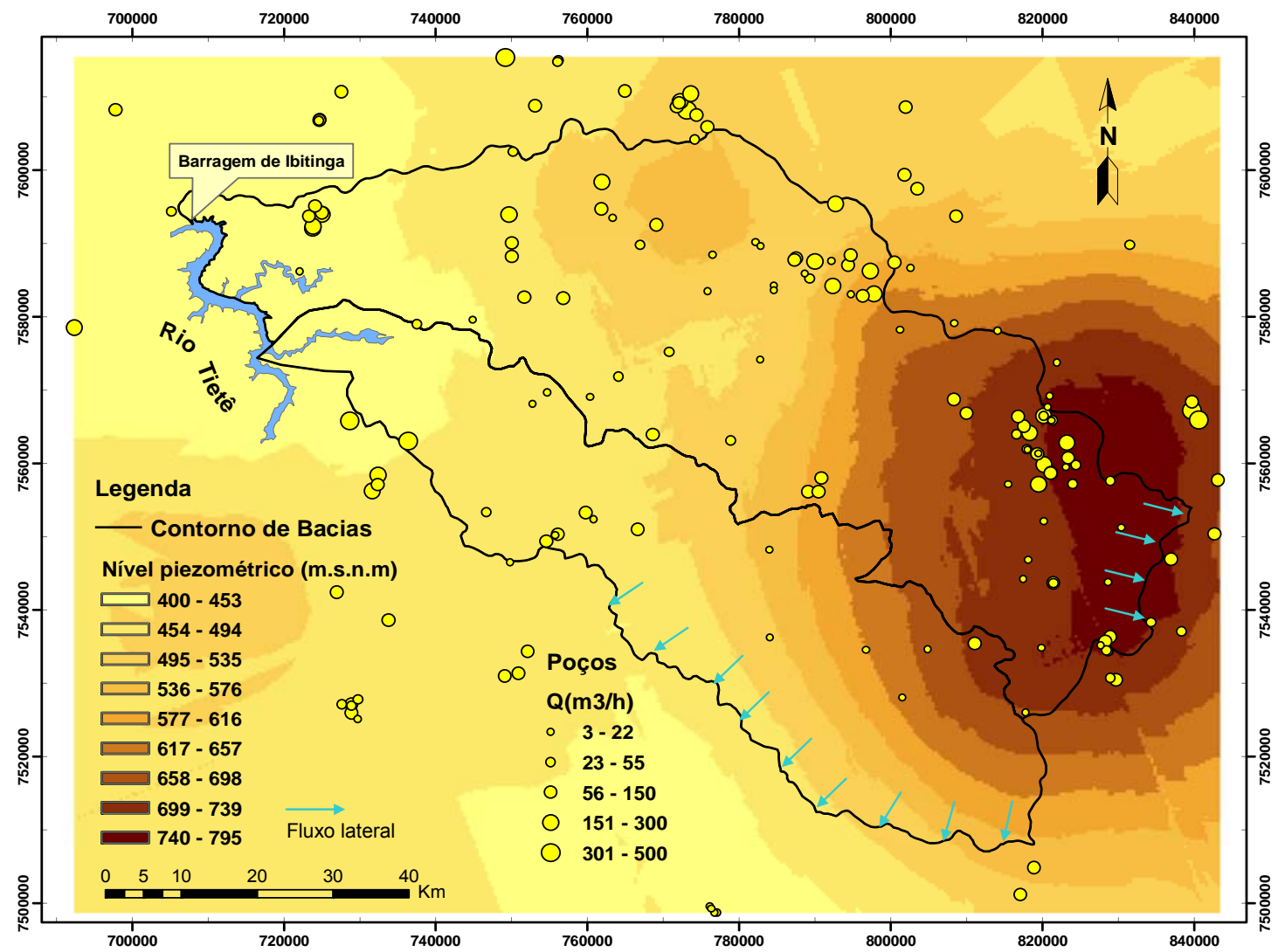

Figura 33 - Níveis piezométricos atribuídos à área das bacias e do seu entorno

Devido à necessidade de se avaliar espacialmente os erros na estimativa das cotas potenciométricas, durante a implementação e calibração do modelo numérico, foi gerada uma estimativa de erros atribuída à interpolação, obtida diretamente do método de interpolação utilizado (krigagem ordinária) (Figura 34). O erro médio obtido para a área das duas bacias foi de $28,2 \mathrm{~m}$ e valores mínimo e máximo de 25,1 e 45,1 m, respectivamente, com um desvio-padrão de 3,2 m. Os valores maiores se encontram na saída das bacias e na região sudeste da bacia do Jacaré-Pepira. 


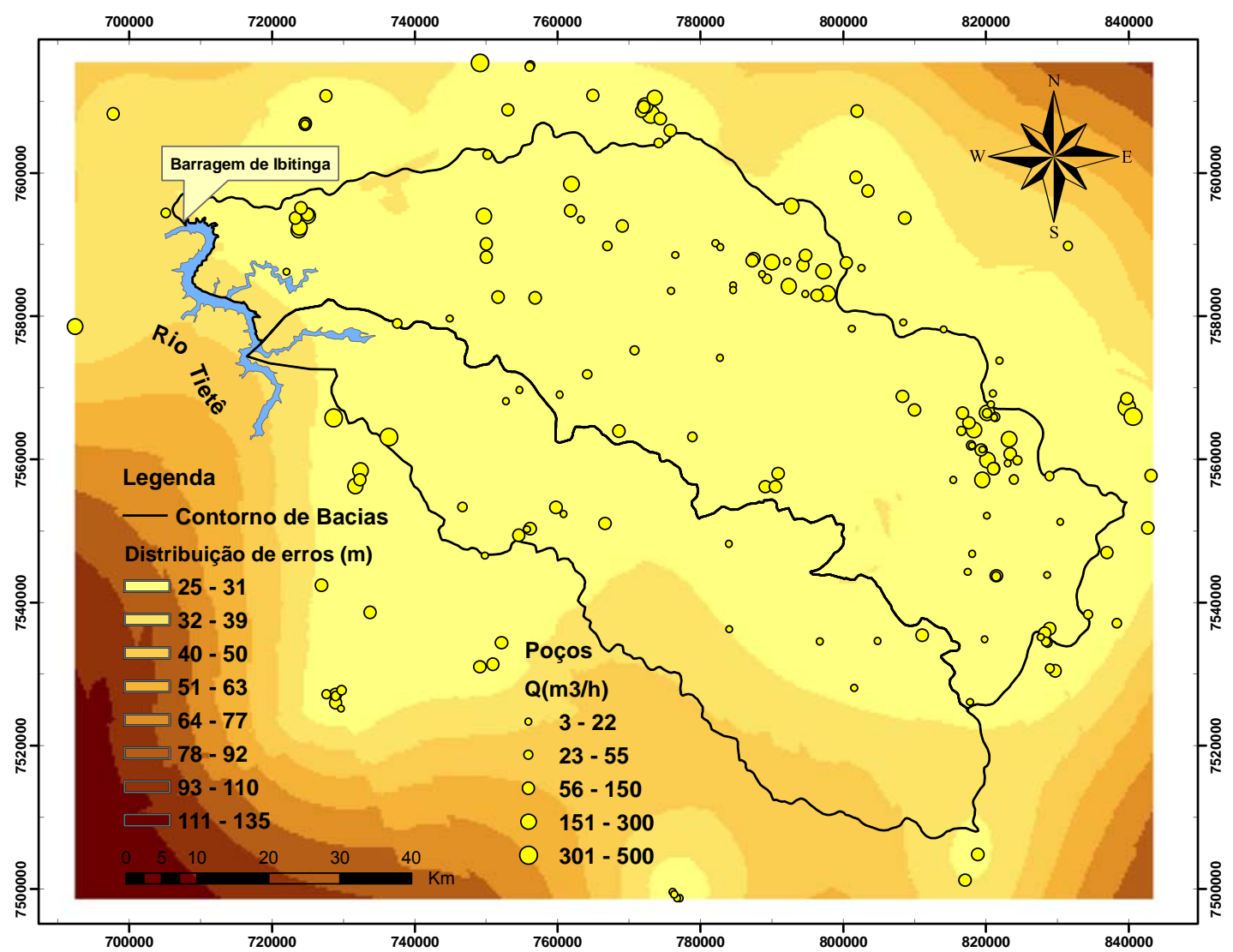

Figura 34 - Distribuição dos erros atribuídos à estimativa dos níveis piezométricos

\subsubsection{Perfis Hidrogeológicos}

São traçadas duas seções de perfis hidrogeológicos, A-B e C-D, respectivamente, longitudinal e transversal à área de estudo, aproximadamente nas direções NW-SE e N-S, (Figura 35). Os perfis foram obtidos diretamente dos dados interpolados das cotas planialtimétricas, de base, de topo, e de níveis piezométricos do aqüífero. O propósito é avaliar a coerência dos dados obtidos das interpolações (Figura 36).

Entre 100.000 e $105.000 \mathrm{~m}$ da origem do perfil longitudinal (A-B), e próximo à Represa do Lobo, observam-se cotas potenciométricas elevadas e cotas de topo do aqüífero significativamente abaixo do nível do solo, em zona de afloramento do aqüífero. Essa inconsistência local ocorre próxima a uma região 
de arenito/basalto intercalados. A ocorrência desta estrutura geológica provoca a presença de aqüíferos suspensos com níveis piezométricos e espessura significativamente variáveis com a distância (dados obtidos de poços), acarretando incertezas maiores na definição local dos contornos do aqüífero.

O valor médio da espessura ao longo da seção longitudinal (A-B) é de 205 $\mathrm{m}$, variando de 134 a $246 \mathrm{~m}$, e desvio-padrão de $30 \mathrm{~m}$, enquanto que ao longo do perfil transversal (C-D) a média é de 199 m, variando de 137 a 262 m, e desviopadrão de $36 \mathrm{~m}$. Esses valores guardam uma proporção semelhante à obtida entre as espessuras médias das regiões de aqüífero livre e confinado, 191 e 183 $\mathrm{m}$, respectivamente.

Os níveis potenciométricos nos perfis mostram-se coerentes, baseados em algumas regiões onde são determinados (rios e lagos) ou estimados com dados de nível estático e estratigrafia mais confiáveis.

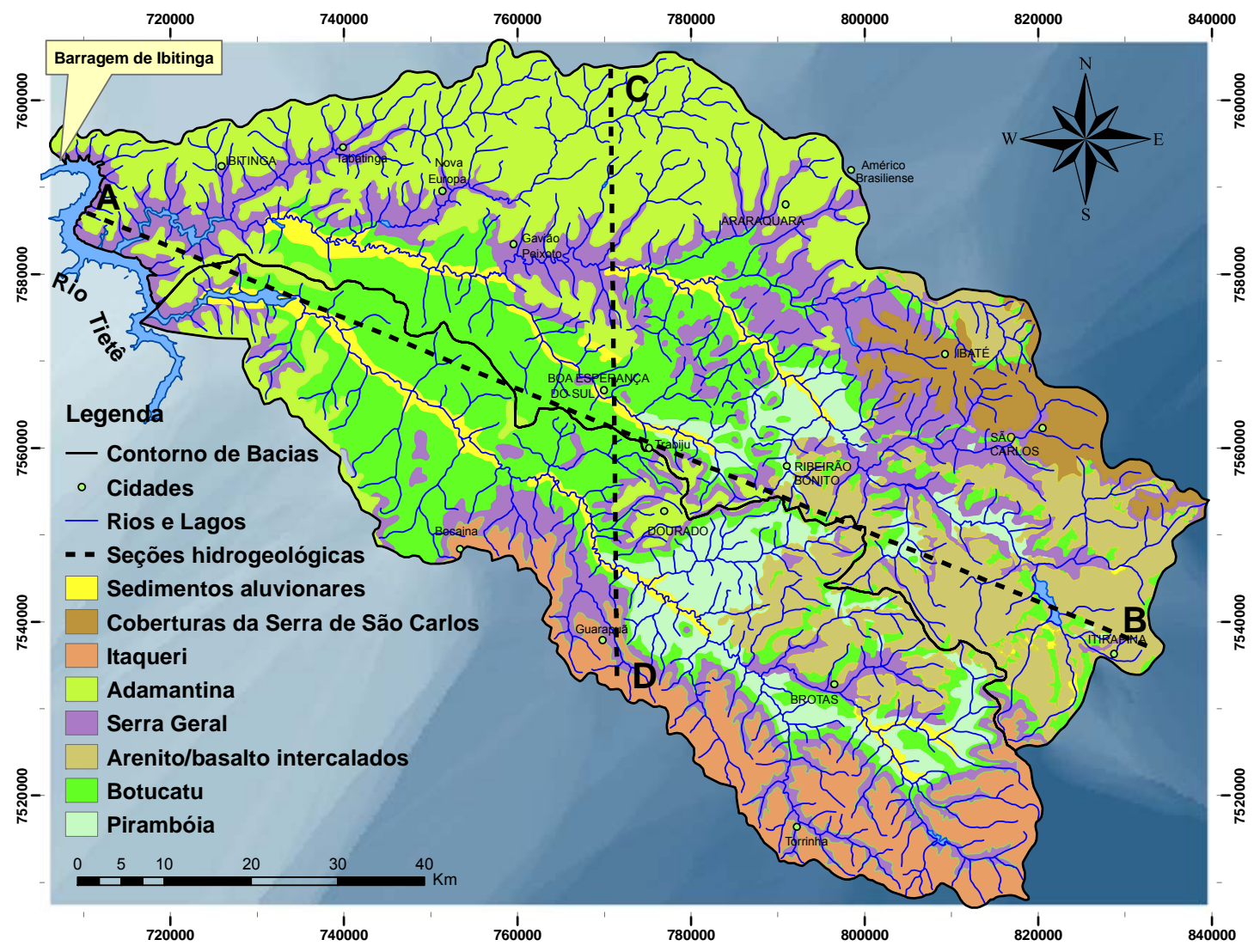

Figura 35 - Seções hidrogeológicas 
No perfil longitudinal, os primeiros 15.000 m apresentam um desnível de 300 $\mathrm{m}$ do aqüífero. Esse comportamento é coerente com a estratigrafia obtida de alguns poços do aqüífero Serra Geral na região, que apresentam comumente espessuras de 250 a 300 m de basaltos, sobre a Formação Botucatu. Este comportamento estratigráfico, juntamente com o elevado nível potenciométrico e a característica de semiconfinamento dos basaltos, indicam, apesar do mergulho do Aqüífero Guarani, a continuidade da interação rio-aqüífero na região jusante das bacias, correspondente à represa de Ibitinga.

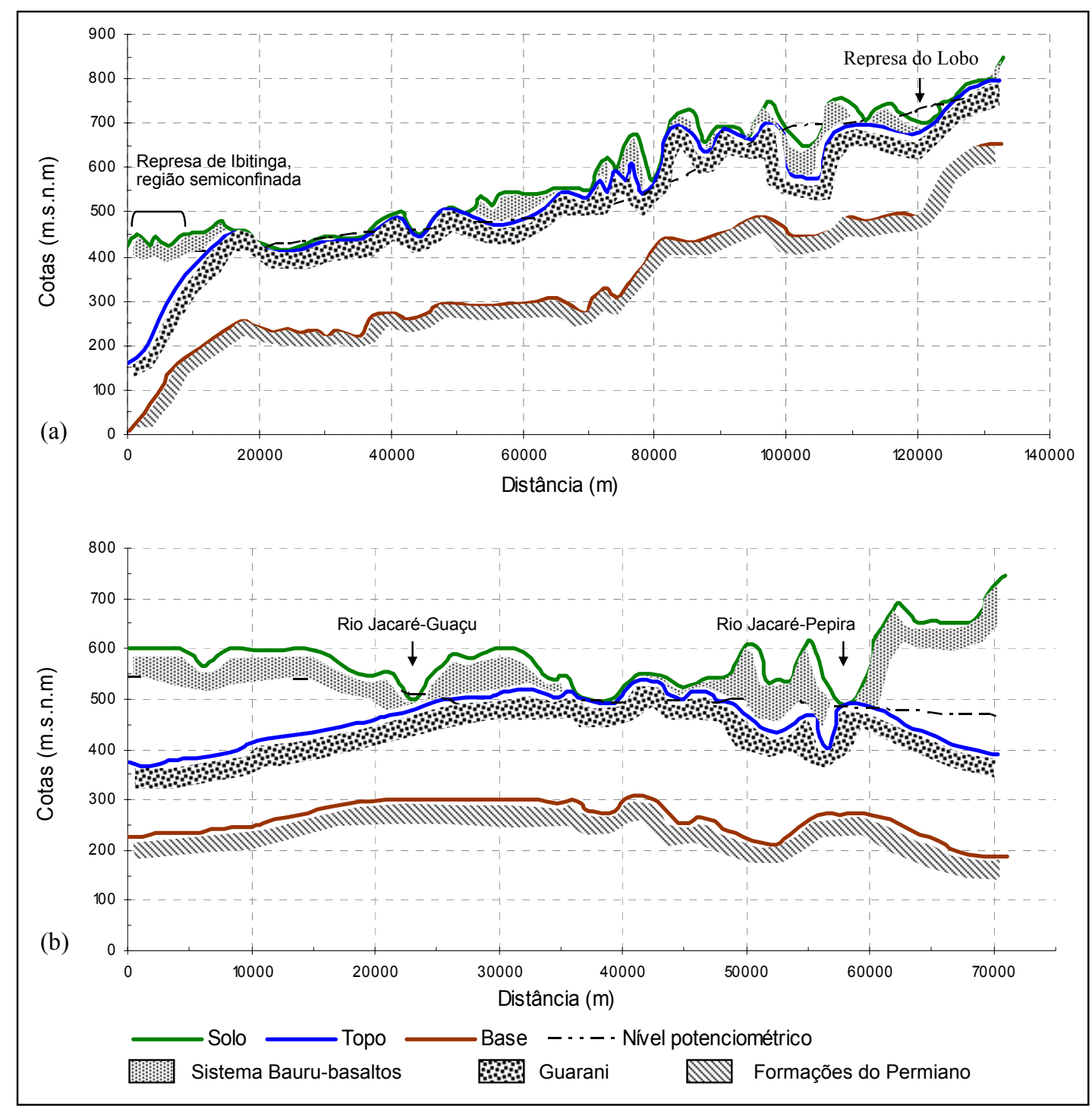

Figura 36 - Perfis hidrogeológicos com os valores de cotas de base e topo do Aqüífero Guarani e nível potenciométrico. (a) seção longitudinal (A-B), sentido NW-SE, (b) seção transversal (C-D), sentido N-S. 


\subsubsection{Interação rio-aqüífero}

A definição das zonas de interação rio-aqüífero tem o objetivo de estabelecer os trechos do Aqüífero Guarani que possuem carga hidráulica próxima a dos rios, as quais são tomadas no modelo numérico para atribuição de condição de contorno de $1^{\circ}$ tipo (carga constante). Elas são representadas por pontos ao longo do delineamento dos rios, e passados ao modelo numérico como dados do tipo $x, y, h$ (coordenadas de posição e valor de carga hidráulica).

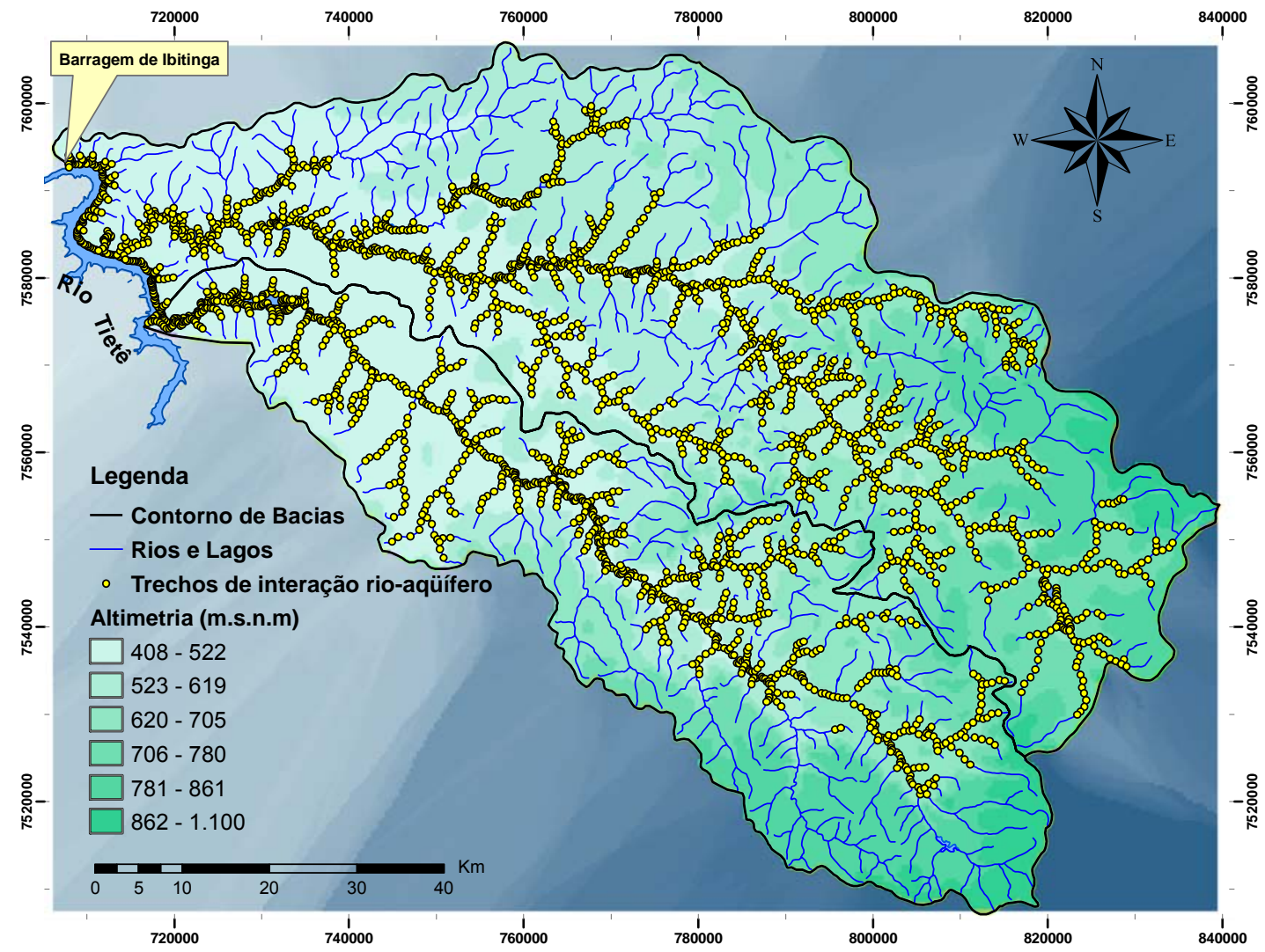

Figura 37 - Trechos de interação rio-aqüífero

A região de interação rio-aqüífero foi estabelecida comparando-se as cotas de superfície potenciométrica do aqüífero com as correspondentes cotas altimétricas no delineamento dos rios. Foram consideradas zonas de interação as regiões que apresentam diferença entre esses conjuntos, inferior ou igual ao erro médio estimado para a superfície potenciométrica $(28,2 \mathrm{~m})$ (Figura 37). Nessas condições, os pontos mais a montante nos trechos dos rios apresentam maior grau de incerteza. 
Para que as condições de contorno possam ser aplicadas corretamente ao modelo numérico, é necessário que os dados $x, y, h$ possuam valores de $h$ que diminuam, ou se mantenham constantes, de montante a jusante ao longo de todos os trechos de rio. Isso não é inteiramente possível utilizando as operações SIG disponíveis, que produz um conjunto de $x, y, h$, na direção rio a baixo, que freqüentemente inverte o sentido descendente de $h$. Isso é uma decorrência dos erros atribuídos às cotas planialtimétricas $(25 \mathrm{~m})$ e do espaçamento médio entre os pontos considerados ao longo dos rios (600 m).

Com o objetivo de gerar um conjunto de pontos $x, y, h$ com as características necessárias, foi selecionado um subconjunto de pontos com carga hidráulica descendente ao longo de todos os trechos de drenagem (utilizando-se o mapa potenciométrico), e elaborado um algoritmo para interpolação de valores $h$ para os demais pontos selecionados, perfazendo 371 trechos com 3.073 pontos (arquivo tipo shapefile). O algoritmo de interpolação, implementado em linguagem visual basic, é orientado a Arcobjetos e executável no próprio ambiente SIG (ArcGis). O aplicativo desenvolvido, além da interpolação, também converte o arquivo de pontos, de shapefile para ASCII, e exporta os dados em formato próprio do simulador numérico utilizado (SPA). O código fonte do aplicativo, instruções de instalação e utilização encontram-se no Apêndice B.

\subsection{MODELO NUMÉRICO}

A implementação do modelo conceitual foi realizada em modelo numérico bidimensional horizontal, heterogêneo e isotrópico com recarga distribuída, aplicado sob condições de aqüífero livre e confinado, tomando como domínio o contorno externo conjunto das bacias e cotas variáveis de base e de topo do aqüífero. Foram utilizadas condições de contorno de carga especificada (condição de $1^{\circ}$ tipo ou de Dirichlet) e de fluxo especificado (condição de $2^{\circ}$ tipo ou de Neumann). O método numérico utilizado foi o de elementos finitos (MEF) e na geração automática de malha não-estruturada utilizou-se o método de triangulação de Delaunay. O aplicativo de simulação numérica utilizado para a implementação desses métodos e técnicas foi o SPA (Simulador de Processos em Aqüíferos) 
(WENDLAND, 2003), um pacote de programas estruturado em módulos, baseado em sistema operacional Linux.

\subsubsection{Aquisição de dados}

Os dados georeferenciados, obtidos pelo SIG, foram convertidos em arquivo tipo ASCII e colocados em formatação adequada aos arquivos de entrada do CMA (WENDLAND, 2003) - módulo Construtor de Modelos de Aquifero do SPA. Os dados utilizados pelo simulador numérico são divididos em conjuntos representando os diversos parâmetros considerados (base e topo do aqüífero, carga hidráulica, vazão de poços etc); são todos reconhecidos apenas como pontos $x, y$ ou $x, y, z$, nos quais as duas primeiras coordenadas são de posição e a terceira, quando existente, é o valor individual do parâmetro no conjunto de dados. Os dados são classificados em dois grupos:

a) contornos internos e externos;

b) estruturas.

Os primeiros (contornos internos e externo) são os conjuntos de dados considerados na geração da malha, suas coordenadas de posição são representadas exatamente nas coordenadas de posição de nós da malha, enquanto os demais (estruturas) são atribuídos posteriormente aos nós da malha gerada, por interpolação linear. Foram considerados como contorno, apenas os rios, poços e limite das bacias, perfazendo 4.086 pontos. Entre os dados tipo estrutura, alguns foram passados ao modelo numérico já com interpolação dos dados originais (no ambiente SIG, utilizando-se método de krigagem), em um grid de 400x400 m. Posteriormente, esses dados foram mais uma vez interpolados aos nós da malha, no ambiente de simulação numérica (SPA). Isso se deve à existência de melhores recursos de análise da interpolação em ambiente SIG. Os dados tipo estrutura perfizeram 152.904 pontos (Tabela 13). Detalhes da distribuição espacial, na malha, dos dados tipo contorno e exemplos de dado tipo estrutura encontram-se na seção seguinte. 
Tabela 13 - Característica dos dados utilizados no modelo numérico

\begin{tabular}{l|c|c|c|c|r}
\multicolumn{1}{c|}{ Descrição } & Contorno & Estrutura & $\begin{array}{c}\text { Ambiente de } \\
\text { interpolação }\end{array}$ & Tipo & $\begin{array}{c}\text { Quantidade } \\
\text { de pontos }\end{array}$ \\
\hline \hline Contorno de bacias & $\mathrm{X}$ & & - & $\mathrm{X}, \mathrm{y}$ & 782 \\
\hline $\begin{array}{l}\text { Rios (trechos com } \\
\text { interação rio- aqüífero) }\end{array}$ & $\mathrm{X}$ & & - & $\mathrm{X}, \mathrm{y}, \mathrm{h}^{(1)}$ & 3.073 \\
\hline Poços & $\mathrm{X}$ & & - & $\mathrm{X}, \mathrm{y}, \mathrm{Q}^{(2)}$ & 231 \\
\hline Estações fluviométricas & & $\mathrm{X}$ & simulação & $\mathrm{X}, \mathrm{y}$ & 12 \\
\hline Nível estático & & $\mathrm{X}$ & SIG/simulação & $\mathrm{X}, \mathrm{y}, \mathrm{h}$ & 42.176 \\
\hline Planialtimetria & & $\mathrm{X}$ & SIG/simulação & $\mathrm{X}, \mathrm{y}, \mathrm{c}^{(3)}$ & 42.173 \\
\hline Base do aqǘffero & & $\mathrm{X}$ & SIG/simulação & $\mathrm{X}, \mathrm{y}, \mathrm{C}$ & 42.173 \\
\hline $\begin{array}{l}\text { Topo do aqüífero } \\
\text { confinado }\end{array}$ & & $\mathrm{X}$ & SIG/simulação & $\mathrm{X}, \mathrm{y}, \mathrm{C}$ & 22.451 \\
\hline Formação Serra Geral & & $\mathrm{X}$ & simulação & $\mathrm{X}, \mathrm{y}$ & 1.987 \\
\hline Formação Adamantina & & $\mathrm{X}$ & simulação & $\mathrm{X}, \mathrm{y}$ & 857 \\
\hline Formação Itaqueri & & $\mathrm{X}$ & simulação & $\mathrm{X}, \mathrm{y}$ & 432 \\
\hline $\begin{array}{l}\text { Sedimentos Serra de São } \\
\text { Carlos }\end{array}$ & & $\mathrm{X}$ & simulação & $\mathrm{X}, \mathrm{y}$ & 231 \\
\hline $\begin{array}{l}\text { Arenito/basalto } \\
\text { intercalados }\end{array}$ & & $\mathrm{X}$ & simulação & $\mathrm{x}, \mathrm{y}$ & 412 \\
\hline
\end{tabular}

${ }^{\text {(1) }}$ Carga hidráulica, ${ }^{(2)}$ Vazão do poço, ${ }^{(3)}$ Cota altimétrica

A formatação dos dados de entrada no padrão do simulador numérico (SPA) foi automatizada a partir de um aplicativo elaborado com esse fim, como descrito na seção 4.2.2.4.

Os dados temporais de entrada e saída, como taxas de recarga e vazões, foram utilizados em valores anuais.

\subsubsection{Geração de malha}

O desempenho computacional está relacionado também à qualidade da malha, que se caracteriza idealmente pela composição de triângulos eqüiláteros e da variação gradual de seus tamanhos. Após a geração da malha foram feitos ajustes automáticos (pelo gerador de malha) e manuais visando melhorar sua qualidade, sobretudo próximo a contornos de geometria mais complexa. Como forma de promover esses ajustes, preliminarmente foi estabelecido um espaçamento mínimo de $600 \mathrm{~m}$ entre os pontos dos contornos, inserindo-se os pontos nos trechos necessários. A definição deste valor se baseou na capacidade de representar as variações geométricas dos contornos, sem sobrecarregar a malha. 
O simulador numérico pode trabalhar com malhas contendo simultaneamente triângulos e quadriláteros (malha mista). Assim, após a triangularização, o gerador de malha avalia e converte as regiões possíveis em quadriláteros, como forma de diminuir posteriormente o esforço computacional da solução numérica. A seguir, são apresentados alguns detalhes da malha (Figura 38, Figura 39 e Figura 40)

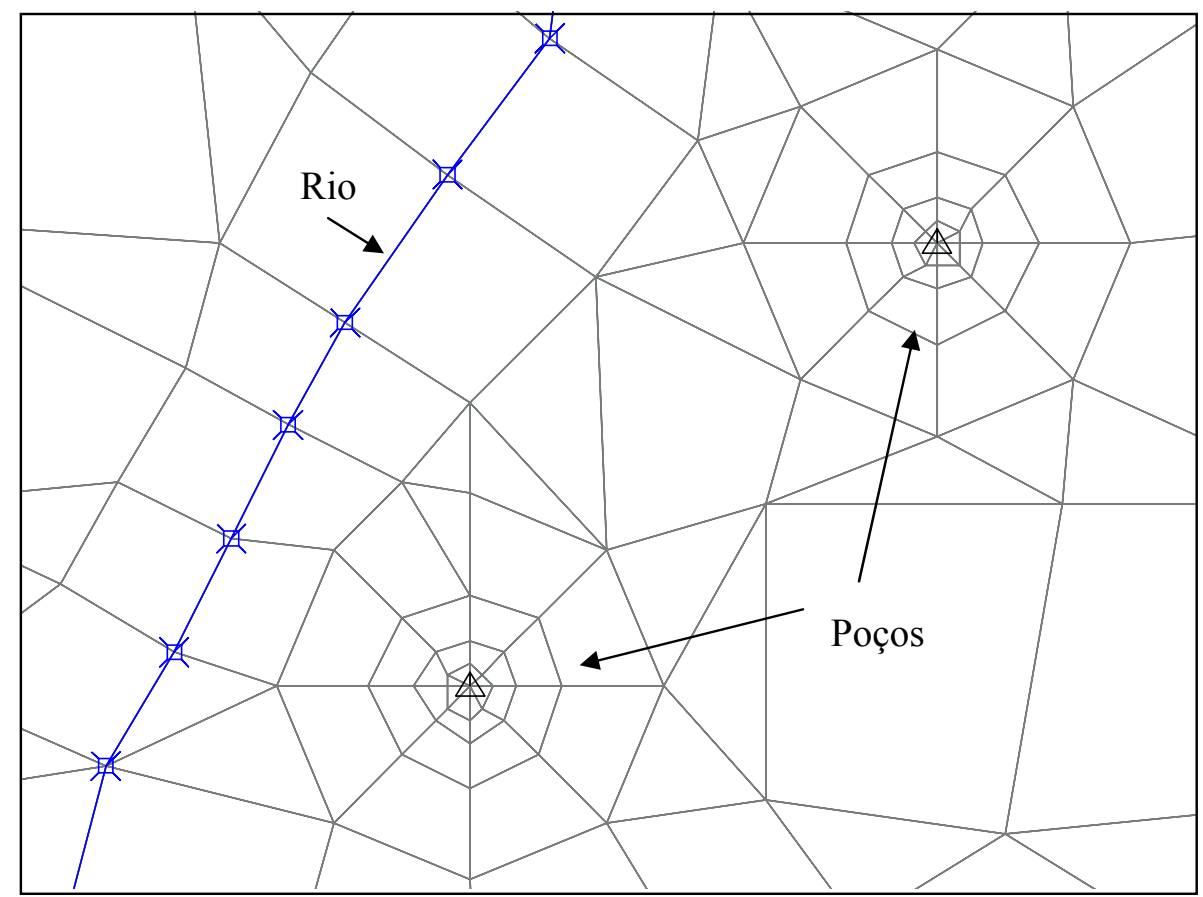

Figura 38 - Detalhe de poços e rio com configuração de malha mista 


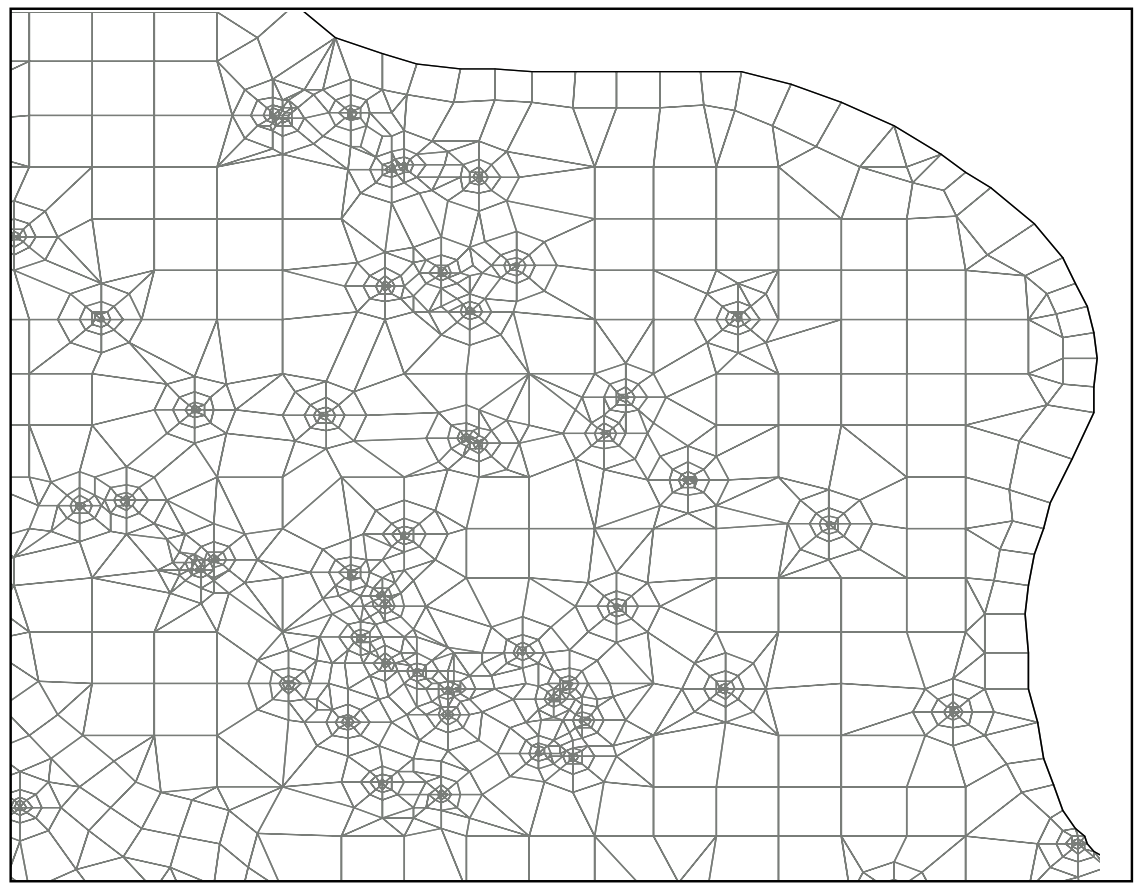

Figura 39 - Trecho da malha apresentando complexidade devido à elevada concentração de poços e contornos na região de São Carlos.

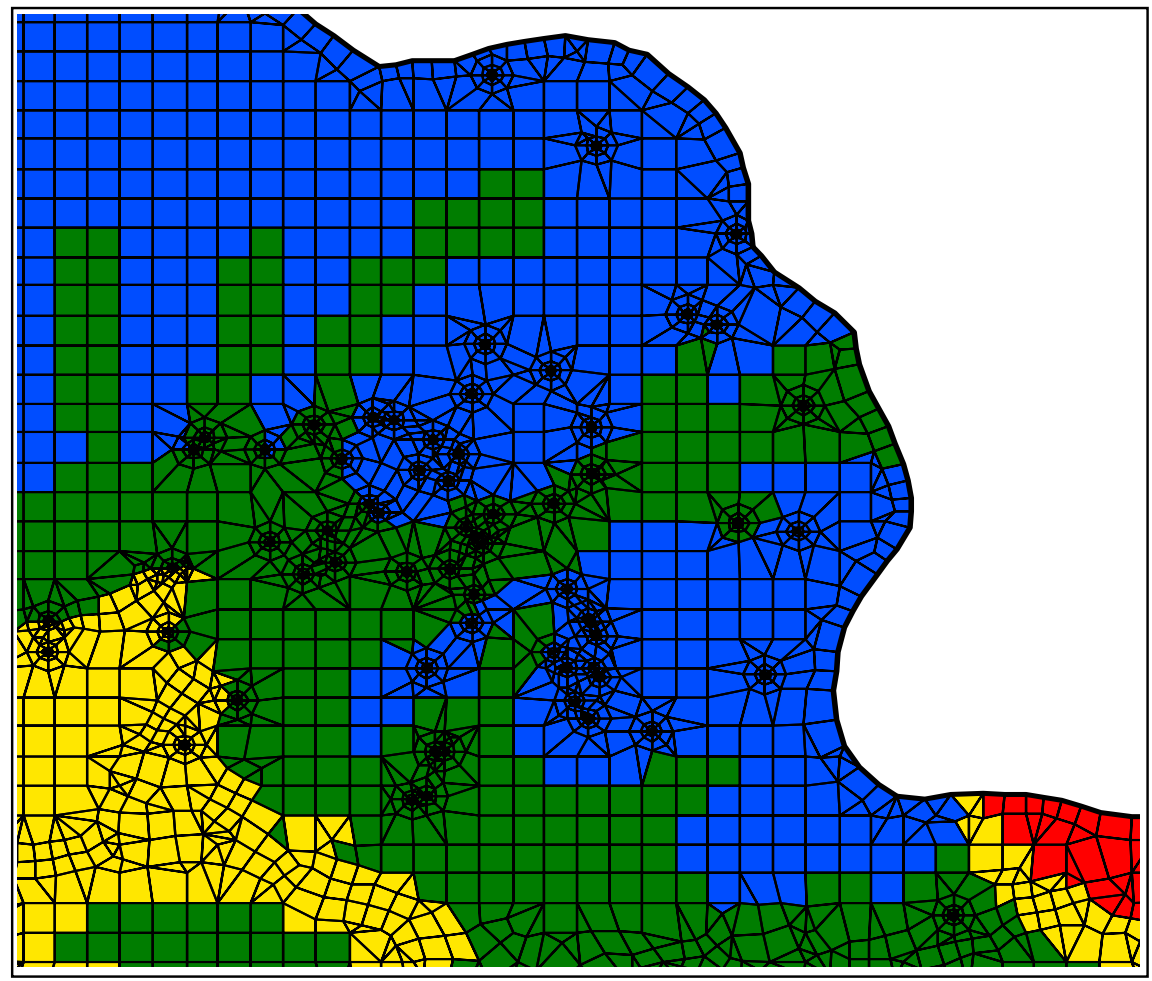

Figura 40 - Detalhe de zonas de recarga, na região de Araraquara, atribuídas à malha, como exemplo de dados tipo estrutura. 


\subsubsection{Recarga e condições de contorno}

A simulação da recarga, explotação de poços, drenagem do aqüífero aos rios e fluxo lateral foi feita pela atribuição de fontes e condições de contorno ao modelo numérico.

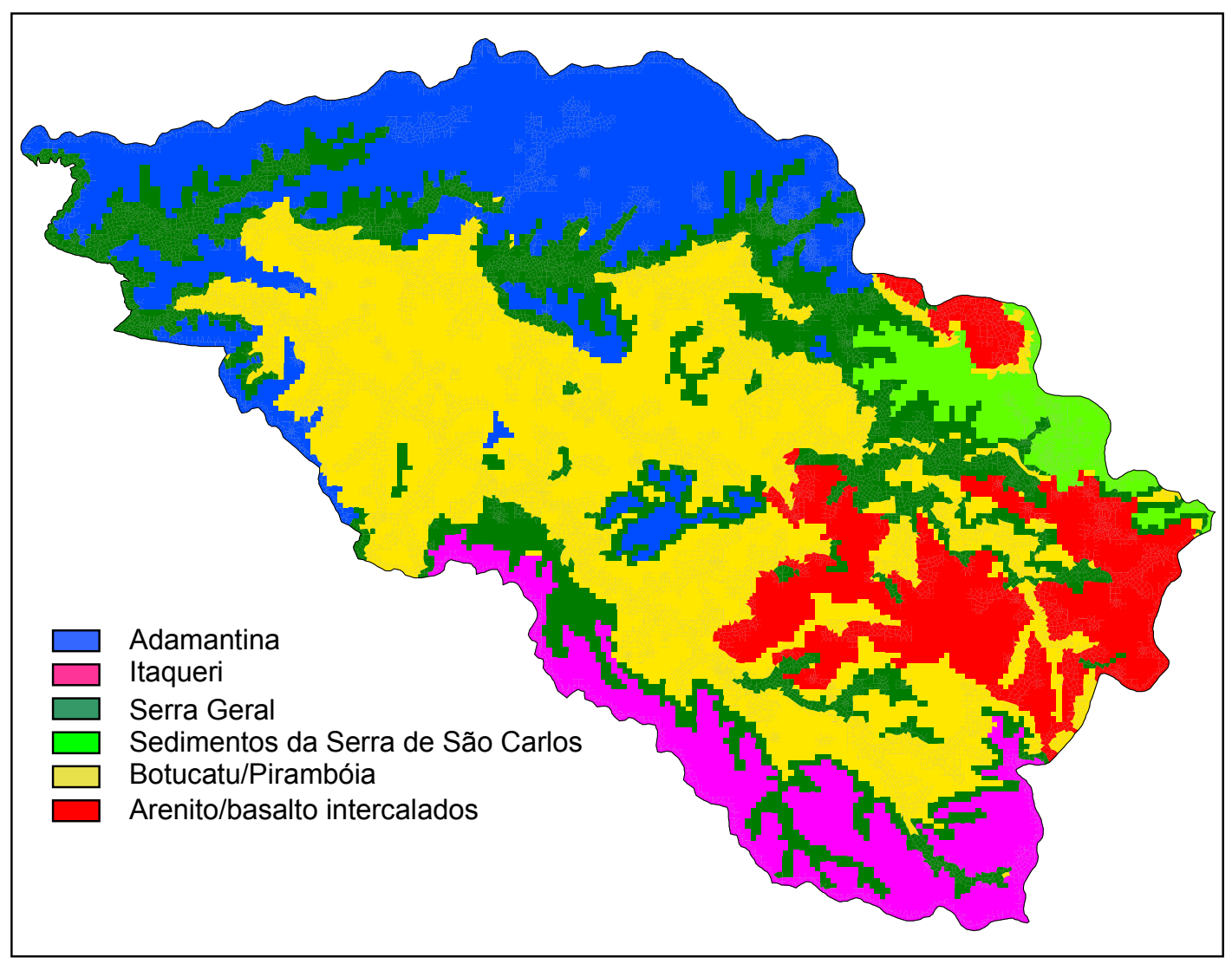

Figura 41 - Zonas de recarga atribuídas por formações

A recarga, atribuída como fonte, foi distribuída aos elementos da malha conforme sua localização em relação às estruturas geológicas (formações geológicas e estruturas afins), definindo as regiões de recarga. Os dados $x, y$ referentes à localização das estruturas geológicas foram convertidos em polígonos, estabelecendo os respectivos elementos da malha. Foram consideradas seis regiões de recarga, correspondentes às respectivas estruturas geológicas consideradas na área das bacias: formações Adamantina, Itaqueri e Serra Geral, Sedimentos da Serra de São Carlos, formações Botucatu/Pirambóia 
e arenito/basalto intercalados (Figura 41). Nas quatro primeiras regiões, o aqüífero é considerado semiconfinado (recarga indireta), enquanto nas duas últimas, o aqüífero é aflorante (recarga direta). Os valores de recarga atribuídos às seis regiões variaram durante a calibração do modelo.

As vazões dos 231 poços de captação foram atribuídas como fontes diretamente aos nós da malha, nas posições correspondentes às posições reais dos poços e especificadas na geração da malha. A descrição das vazões atribuídas foi feita na seção 3.2.3. No processo de calibração do modelo, as vazões dos poços foram desativadas, uma vez que a calibração foi realizada considerando níveis estáticos. Posteriormente, para avaliação da influência dos poços sobre os níveis estáticos, os mesmos foram ativados.

A drenagem do aqüífero aos rios e vice-versa foi simulada por condição de contorno de carga especificada (condição de $1^{\circ}$ tipo, ou de Dirichlet). Os pontos onde são atribuídos os valores de carga especificada coincidem exatamente com nós da malha. As vazões obtidas nesses pontos são uma reação do modelo à restrição da carga. Foram utilizadas condições de $1^{\circ}$ tipo em todos os pontos do aqüífero supostamente em interação com os rios, escolhidos segundo descrição no modelo conceitual, e complementados posteriormente, de modo a melhorar a geração da malha.

Os fluxos laterais são a transposição de manancial entre o domínio do aqüífero e sua vizinhança. Foram simulados por condição de contorno de fluxo especificado (condição de $2^{\circ}$ tipo ou de Neumann). A região de fluxo lateral foi estabelecida a partir da observação do comportamento do nível piezométrico no entorno das bacias (Figura 33). Segundo essa observação, duas regiões do aqüífero, identificadas com essa característica, se situam a montante das bacias, uma a leste da bacia do Jacaré-Guaçu e outra a sul-sudeste da bacia do JacaréPepira (Figura 42). Os pontos onde são atribuídos os valores de fluxo especificado coincidem exatamente com nós da malha, no seu contorno externo. Os valores de vazão foram atribuídos aplicando-se a relação de Darcy,

$$
\begin{aligned}
& q=-K \frac{d h}{d x} \quad,[\mathrm{~L} / \mathrm{T}], \mathrm{e} \\
& Q_{L}=q \cdot h_{e} \quad,\left[\mathrm{~L}^{3} / \mathrm{T} / \mathrm{L}\right],
\end{aligned}
$$


nos quais $Q_{L}$ é o fluxo lateral por unidade de comprimento e $h_{e}$, [L], é a espessura saturada do aqüífero. Identificada a extensao do trecho definido pela condição de contorno, $Q_{L}$ foi dividido entre os correspondentes nós da malha. Os gradientes hidráulicos foram medidos através do contorno externo das bacias, a partir dos dados interpolados dos níveis piezométricos, e à condutividade foi atribuído um valor médio. Foram aplicados valores iniciais de $4 \times 10^{-5} \mathrm{~m} / \mathrm{s}$ para condutividade e (6 a 8) $\times 10^{-3}$ para os gradientes. $Q_{L}$ foi posteriormente alterado durante a calibração do modelo.

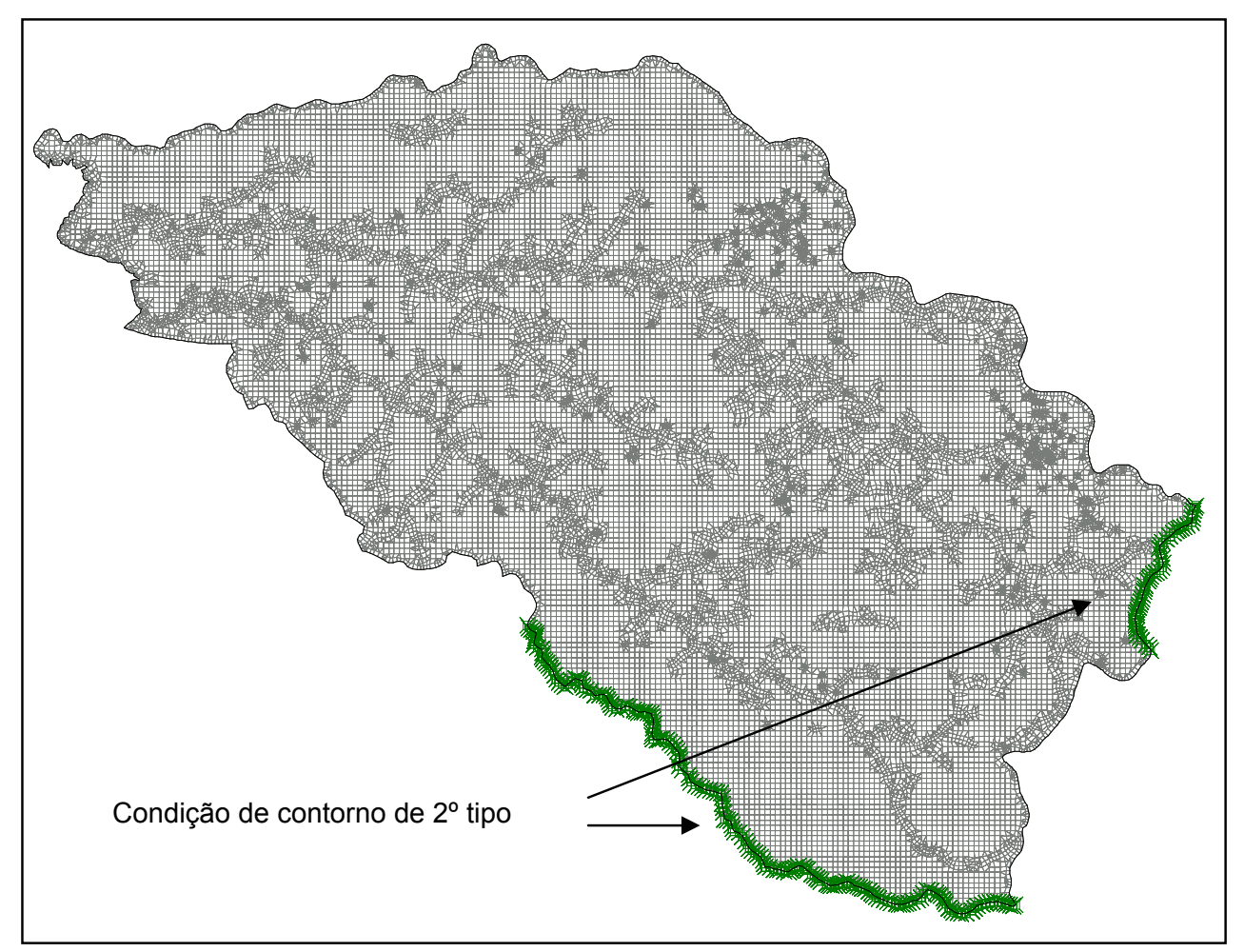

Figura 42 - Trechos da malha com atribuição de condição de contorno de $2^{\circ}$ tipo

\subsubsection{Calibração do modelo}

A calibração do modelo deu-se por meio da comparação entre dados calculados e estimados (ou observados) de dois conjuntos de referência (conjuntos-referência de calibração): 
a) carga hidráulica do aqüífero na área das duas bacias $(h)$;

b) fluxo de base ao longo dos dois rios principais $\left(Q_{b}\right)$.

Os dados de referência da carga hidráulica foram obtidos dos níveis estáticos de 99 poços contidos apenas na área das duas bacias. Eles são um subconjunto dos 170 poços na área das bacias e no seu entorno (Figura 33). Os dados de vazão de base foram obtidos da separação de fluxo de base de hidrogramas, como descrito no modelo conceitual. Os valores de fluxo de base foram determinados em 6 pontos ao longo do Rio Jacaré-Guaçu e 2 ao longo do Rio Jacaré-Pepira, correspondentes aos locais das respectivas estações fluviométricas (Figura 30).

Foram utilizados para a calibração, ajustes nos valores dos seguintes parâmetros (parâmetros de ajuste de calibração, PACs):

a) cargas hidráulicas dos pontos com suposta interação rio-aqüífero $\left(h_{R-A}\right)$;

b) recarga distribuída nas seis zonas de recarga $(R)$;

c) condutividade hidráulica $(K)$;

d) fluxo lateral $\left(Q_{L}\right)$.

Foi realizada uma seqüência iterativa de modificações desses valores. A seqüência de ajustes é esquematizada na Figura 43 e composta de três etapas. $\mathrm{Na}$ etapa 1, os parâmetros de ajuste são fornecidos ao modelo como um conjunto de dados iniciais para simulação; na etapa 2 (Cali), são avaliadas as respectivas raízes dos erros quadráticos médios (root mean square error, RMSE) entre os dados observados, ou estimados, (obs) ou (est) e dados calculados (calc) simultaneamente para os dois conjuntos-referência de calibração, $h$ e $Q_{b}$ :

RMSEH $=\sqrt{\frac{1}{n} \sum_{i=1}^{n}\left(h_{i}^{\text {obs }}-h_{i}^{\text {calc }}\right)^{2}}$

e

$$
R M S E Q=\sqrt{\frac{1}{n} \sum_{i=1}^{n}\left(Q_{b i}^{e s t}-Q_{b i}^{\text {calc }}\right)^{2}},
$$


nos quais $n$ é o número de observações. Na etapa 3, são efetuados os ajustes individuais sobre cada PAC, seguindo os passos de 1 a 4, indicados na Figura 43. A calibração utilizada foi do tipo semi-automática; os parâmetros $h_{R-A}, R$ e $Q_{L}$, foram ajustados manualmente e $K$, automaticamente, utilizando-se o método de minimização dos gradientes hidráulicos, entre os conjuntos observado e calculado, visando simultaneamente obter menores valores de RMSEH e $R M S E Q$, durante as etapas iterativas 2 e 3.

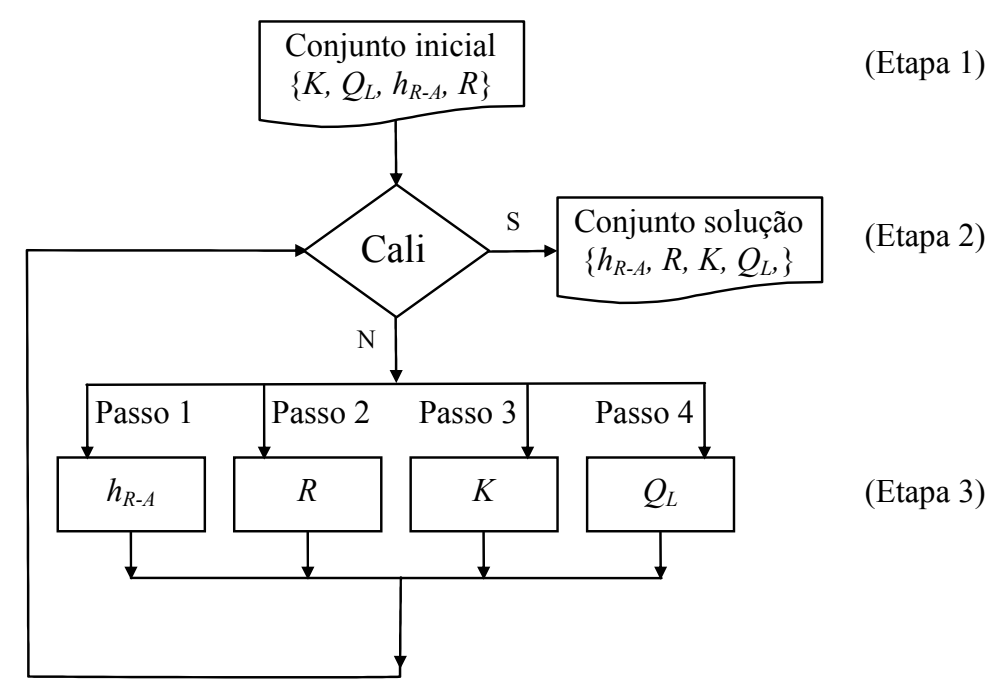

Figura 43 - Seqüência de ajustes de parâmetros utilizados na calibração

Às cargas hidráulicas $\left(h_{R-A}\right)$, foi estabelecida faixa de variação de até $10 \%$, conforme a incerteza atribuída aos níveis estáticos; a condutividade hidráulica $(K)$ foi permitida variar entre $0,2 \times 10^{-5}$ e $5 \times 10^{-5} \mathrm{~m} / \mathrm{s}(0,2$ a $4,3 \mathrm{~m} / \mathrm{d})$, variação admitida para a área de estudo; aos fluxos, lateral $\left(Q_{L}\right)$ e recarga por formação geológica $(R)$, não foram estabelecidos limites prévios de variação por ausência de dados experimentais. Contudo, foram estabelecidas recargas maiores através das formações Botucatu/Pirambóia e arenito/basalto intercalados que através do sistema Bauru-basaltos.

Como avaliação da calibração, foram estabelecidas comparações entre dados observados (ou estimados) e calculados de $h$ e $Q_{b}$ (Figura 44). 


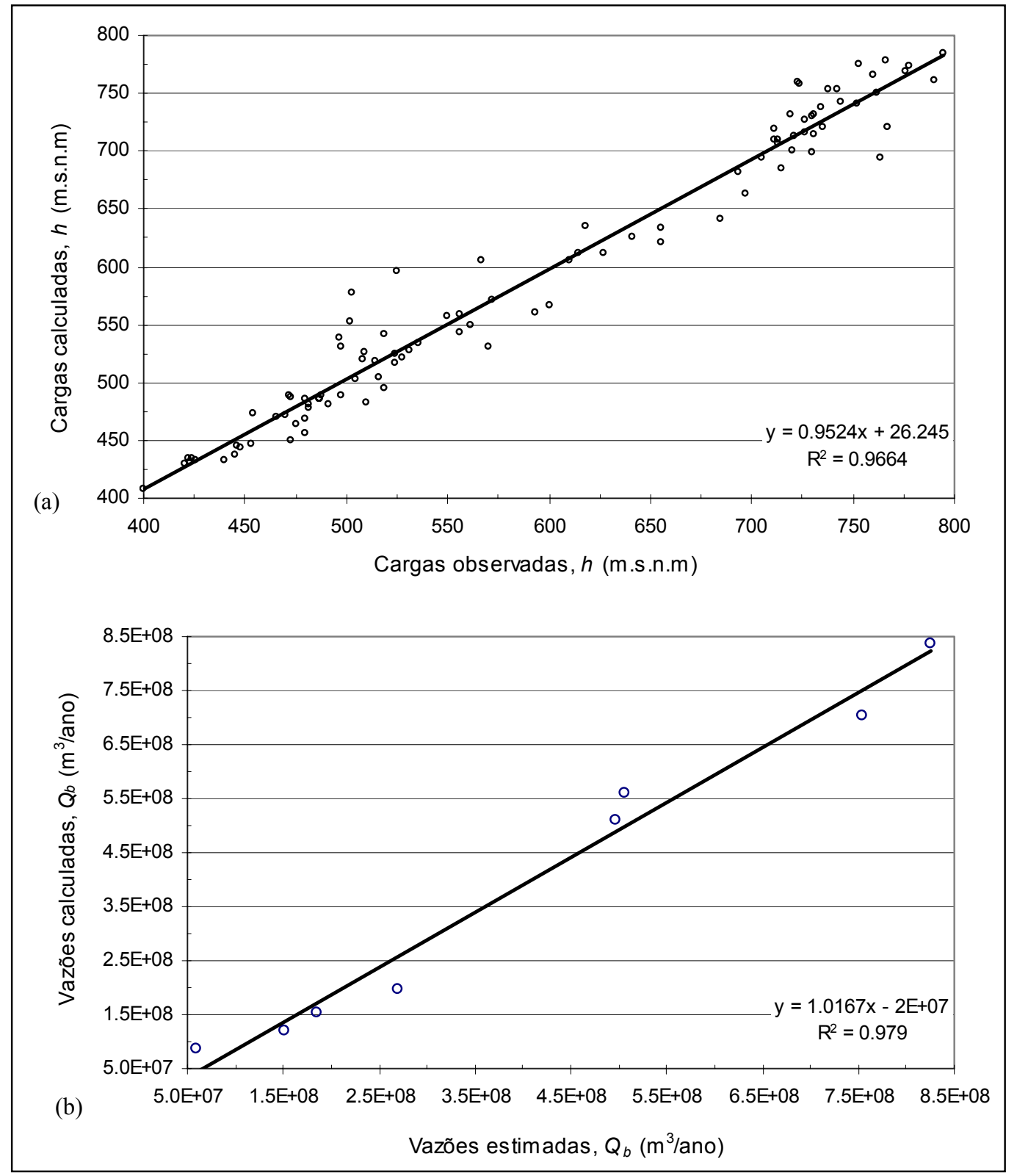

Figura 44 - Dados calculados versus observados (ou estimados) para o modelo calibrado: dados de carga hidráulica $(h)$ e vazão $\left(Q_{b}\right)$, figuras $(a)$ e (b), respectivamente

O coeficiente de correlação $R^{2}$ mostrou uma significativa extensão da relação linear entre dados calculados e observados para ambos os conjuntos $h$ e $Q_{b}, 0,97$ e 0,98 , respectivamente.

A inclinação da linha de melhor ajuste, dos conjuntos $h$ e $Q_{b}$, próxima à unidade, 0,95 e 1,02, respectivamente, é um indicador de baixos desvios obtidos 
entre dados calculados e observados, que, contudo, refletem a capacidade do modelo em simular vazões e cargas hidráulicas ante a complexidade hidrogeológica da área de estudo. Os valores de RMSEH e RMSEQ, relativos às respectivas variações totais observadas de $h$ e $Q_{b}$ foram muito semelhantes, 5,6\% e $5,4 \%$, respectivamente.

As maiores dispersões no conjunto $h$ encontram-se entre as cotas de 490$570 \mathrm{~m}, 710-720 \mathrm{~m}$ e 760-775 m, correspondentes a níveis estáticos de poços nas regiões de Araraquara, São Carlos, Itirapina e Brotas. Esta maior dispersão, correspondente a estas regiões, é atribuída a erros na determinação de nível estático, provenientes da significativa interferência conjunta da explotação de poços (regiões de Araraquara e São Carlos) e da incerteza da interação rioaqüífero (região de Itirapina, Brotas e parte de São Carlos) na área denominada de arenito/basalto intercalados.

Os valores especificados de carga hidráulica, nos locais de suposta interação rio-aqüífero, mais os níveis estáticos observados de 99 poços foram interpolados por krigagem, formando a distribuição estimada de carga hidráulica. Os valores calculados da distribuição de carga hidráulica, ao fim da calibração, são comparados aos valores estimados, na forma de isolinhas (Figura 45).

Os valores das isolinhas calculadas mostraram-se sensíveis às taxas de recarga, enquanto suas formas mostraram-se também sensíveis ao delineamento geral, proveniente da geometria das zonas de recarga, definida pelos contornos das formações e estruturas geológicas, e das zonas de interação rio-aqüífero.

Os valores de escoamento de base foram estimados nos locais das estações fluviométricas nos rios principais, segundo procedimento descrito na seção 4.1. Estes valores, juntamente com os demais componentes de escoamento total, encontram-se na Tabela 14. 


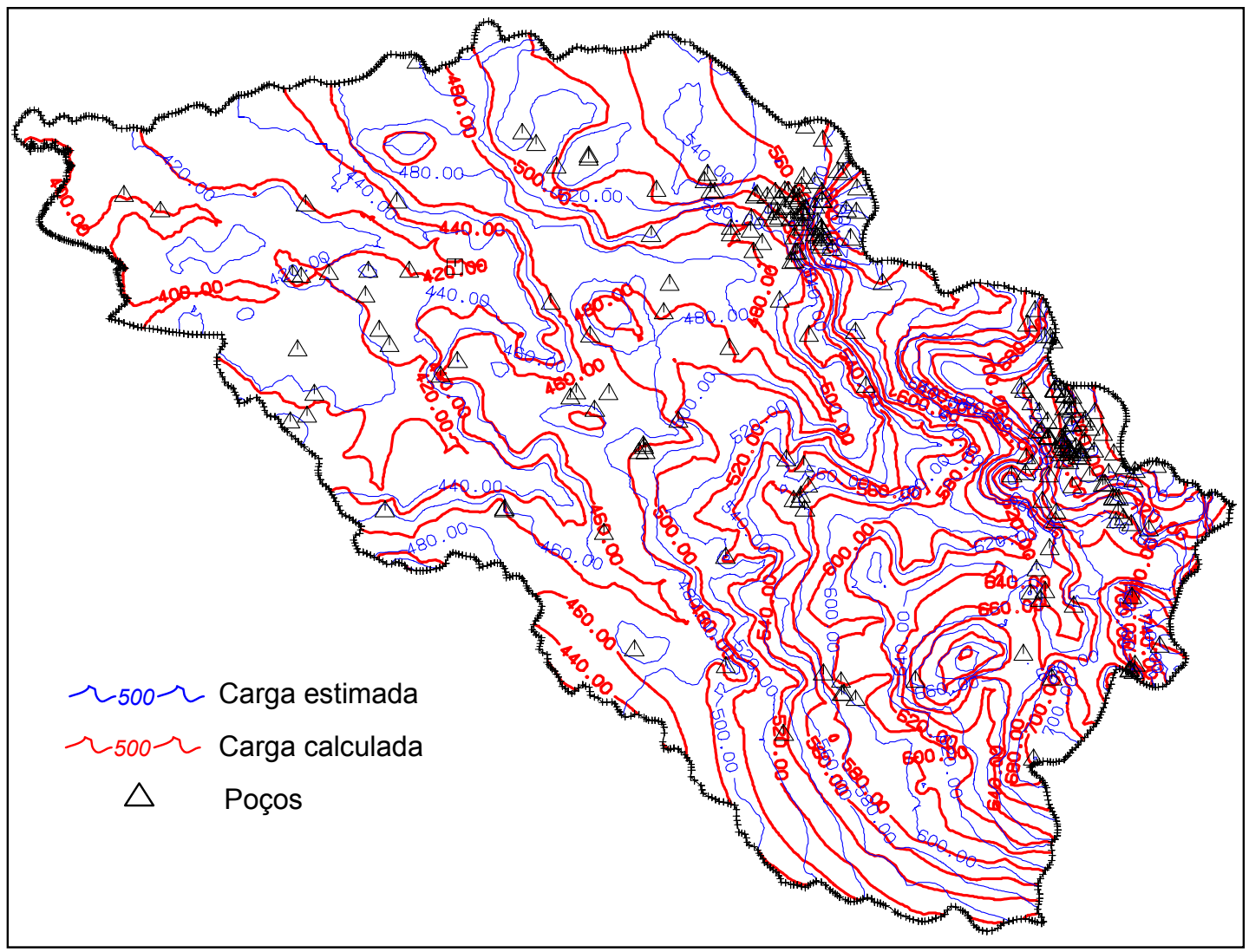

Figura 45 - Isolinhas de carga hidráulica estimada e calculada

Tabela 14 - Vazões estimadas ao longo dos rios, Jacaré-Guaçu (estações E1 a E6) e Jacaré-Pepira (estações E7 e E8)

\begin{tabular}{|c|c|c|c|c|c|c|c|c|}
\hline 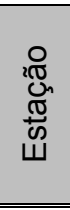 & $\begin{array}{c}Q_{t} \\
\left(\frac{10^{6} \mathrm{~m}^{3}}{\text { ano }}\right)\end{array}$ & $\begin{array}{c}Q_{b t} \\
\left(\frac{10^{6} \mathrm{~m}^{3}}{\text { ano }}\right)\end{array}$ & $\begin{array}{c}Q_{b B / b} \\
\left(\frac{10^{6} \mathrm{~m}^{3}}{\text { ano }}\right)\end{array}$ & $\begin{array}{c}Q_{b G} \\
\left(\frac{10^{6} \mathrm{~m}^{3}}{\text { ano }}\right)\end{array}$ & 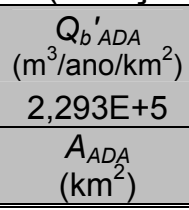 & 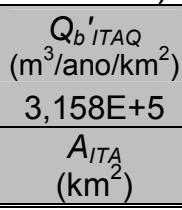 & $\begin{array}{c}\begin{array}{c}Q_{b}{ }^{\prime} s S C \\
\left(\mathrm{~m}^{3} / \mathrm{ano} / \mathrm{km}^{2}\right) \\
3,344 \mathrm{E}+5 \\
A_{S s C} \\
\left(\mathrm{~km}^{2}\right)\end{array} \\
\end{array}$ & $\begin{array}{c}Q_{b}^{\prime}{ }_{B O T} \\
(-) \\
0,9392 \\
A_{B O T} / A \\
(-) \\
\end{array}$ \\
\hline E1 & $1.481,8$ & 1050,0 & 225,0 & 825,0 & 793,5 & 9,6 & 119,5 & - \\
\hline E2 & $1.218,9$ & 889,2 & 135,6 & 753,6 & 404,0 & 9,6 & 119,5 & - \\
\hline E3 & 764,0 & 553,8 & 57,6 & 496,2 & 63,5 & 9,6 & 119,5 & - \\
\hline $\mathrm{E} 4^{*}$ & 359,5 & 282,7 & 13,9 & 268,8 & - & - & - & 0,7960 \\
\hline $\mathrm{E} 5^{*}$ & 246,5 & 199,0 & 13,9 & 185,1 & - & - & - & 0,7993 \\
\hline E6 ${ }^{*}$ & 199,6 & 164,9 & 13,9 & 151,0 & - & - & - & 0,8053 \\
\hline E7 & 792,9 & 692,9 & 185,9 & 507,0 & 72,0 & 536,5 & 0,0 & - \\
\hline E8 & 216,2 & 125,1 & 65,9 & 59,2 & 0,0 & 208,7 & 0,0 & - \\
\hline
\end{tabular}

$\left(^{*}\right)$ Vazão de base determinada com a Relação 20; as demais são determinadas com a Relação 19

Os escoamentos de base estimado e calculado encontram-se na Figura 46. 
Durante a calibração do conjunto $Q_{b}$, as modificações dos parâmetros de ajuste aplicados à região da bacia do Jacaré-Guaçu mostraram-se interferentes na calibração das vazões de base da bacia do Jacaré-Pepira. Assim, a calibração considerou o efeito conjunto das duas bacias visando à diminuição dos desvios entre valores calculados e estimados.

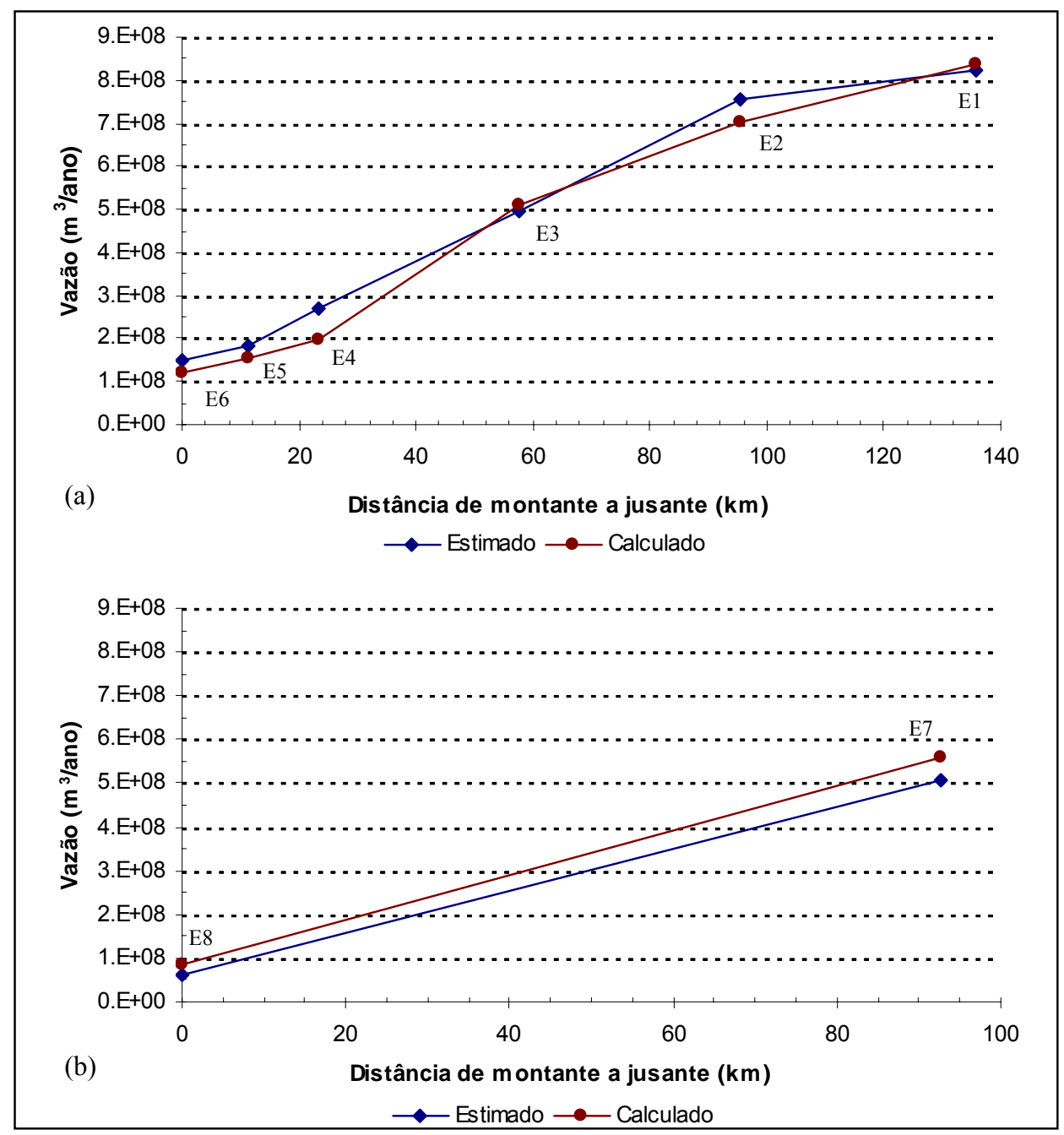

Figura 46 - Vazões de base estimada e calculada para o Aqüífero Guarani, referentes às estações fluviométricas ao longo dos rios Jacaré-Guaçu (E1 a E6) (a) e Jacaré-Pepira (E7 e E8) (b)

Apesar de não se tratar de um terceiro conjunto de referência de calibração, as regiões de escoamento de base positivo/negativo são também uma restrição na calibração, por sua sensibilidade aos parâmetros de ajuste e por ser a incidência de escoamento de base positivo teoricamente aceita apenas nas 
regiões de suposta interação rio-aqüífero, próximas a regiões onde o Guarani é semiconfinado pelas formações do sistema Bauru-basaltos. Durante a calibração do modelo, foi possível estabelecer trechos nos quais o escoamento de base possui valores positivos (injeção ou recarga do aqüífero) e negativo (drenagem ou descarga do aqüífero). Estes escoamentos obtidos são uma reação à especificação de carga hidráulica (condição de contorno de $1^{\circ}$ tipo, Figura 47 ).

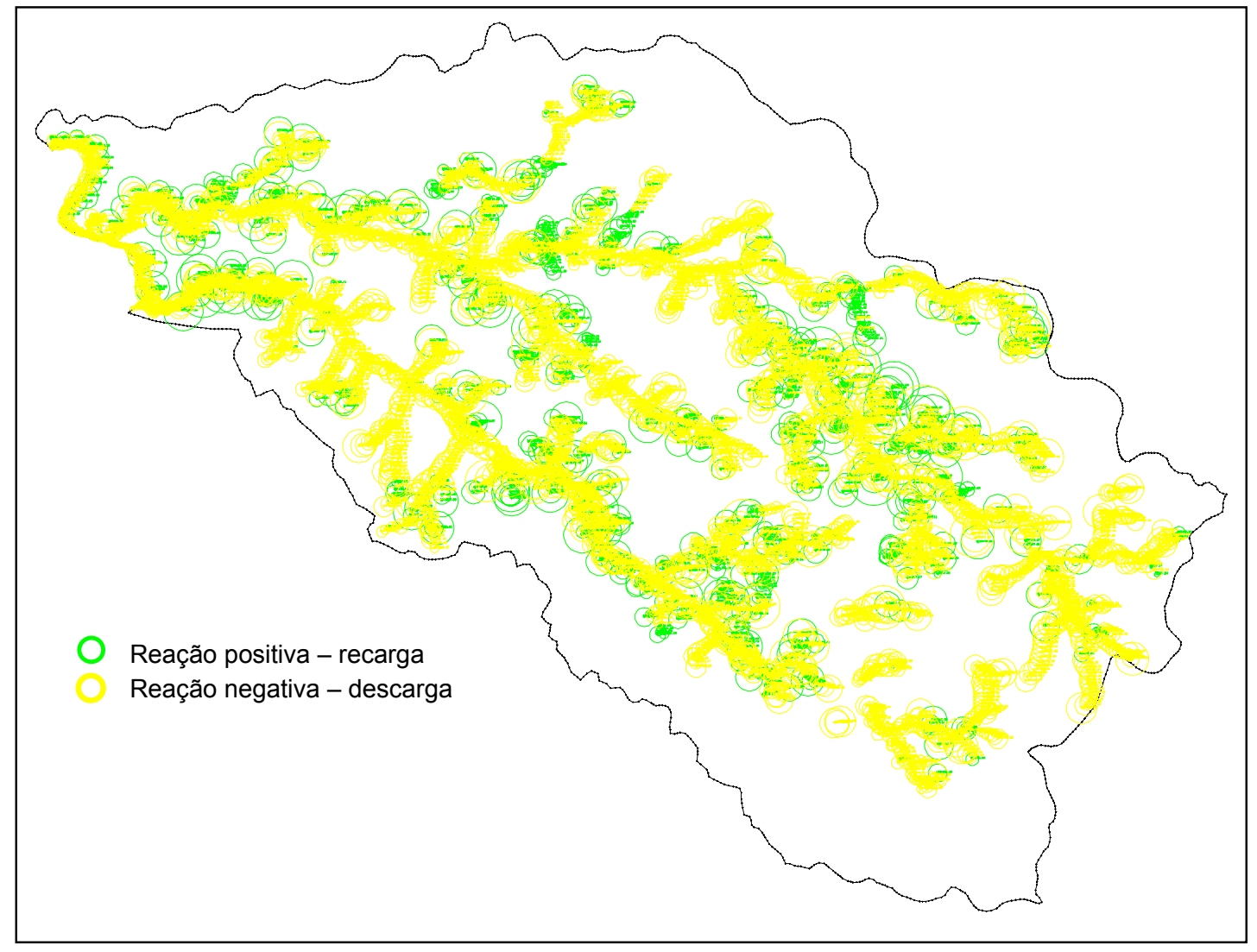

Figura 47 - Escoamentos de base decorrentes da especificação de cargas hidráulicas

Um esboço ilustrando estes escoamentos é apresentado na Figura 48.

O valor total obtido das vazões anuais de fluxo lateral $\left(Q_{L}\right)$ foi de $1,17 \times 10^{8}$ $\mathrm{m}^{3}$. 


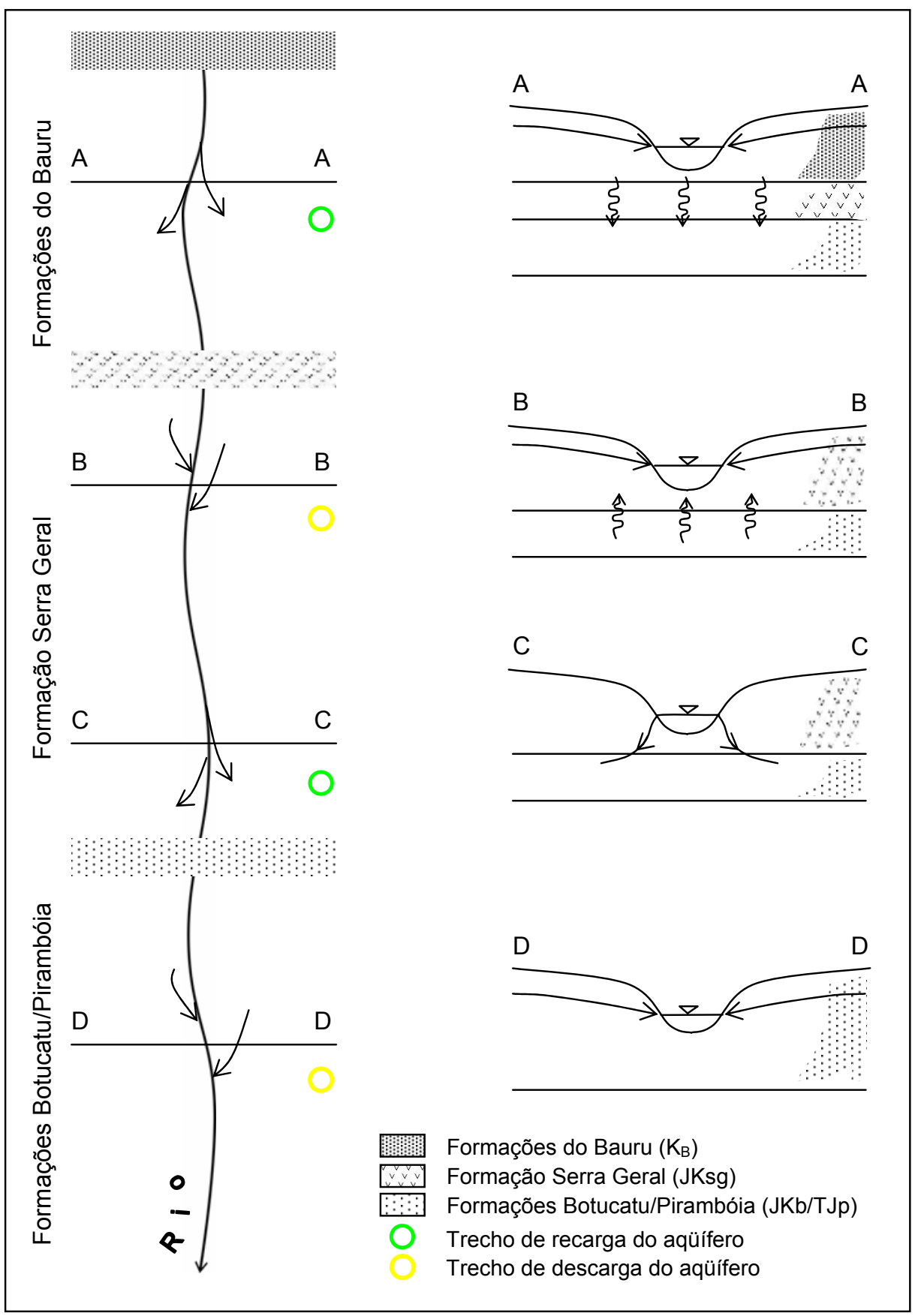

Figura 48 - Interacao rio-aqüífero (trechos de recarga e descarga), em relação às formações geológicas mostradas em seções, em plano (lado esquerdo) e em corte (lado direito)

O valor obtido da condutividade hidráulica média ${ }^{1}(K)$ foi de $2,4 \mathrm{~m} / \mathrm{d}$. Esse valor esta dentro dos limites mínimo e máximo de condutividade hidráulica $(0,2$ -

\footnotetext{
${ }^{1}$ Média ponderada em relação às áreas das células que compõem a malha do modelo numérico.
} 
4,6 $\mathrm{m} / \mathrm{d}$ ), indicados nos trabalhos anteriormente referidos sobre o tema (BORGHETTI et al., 2004; CORRÊA, 1995; DAEE, 1974) e próximo ao valor médio, referido por BORGHETTI et al. (2004), $3 \mathrm{~m} / \mathrm{d}$. A distribuição da condutividade hidráulica obtida para a área de estudo, após a calibração do modelo, encontra-se na Figura 49.

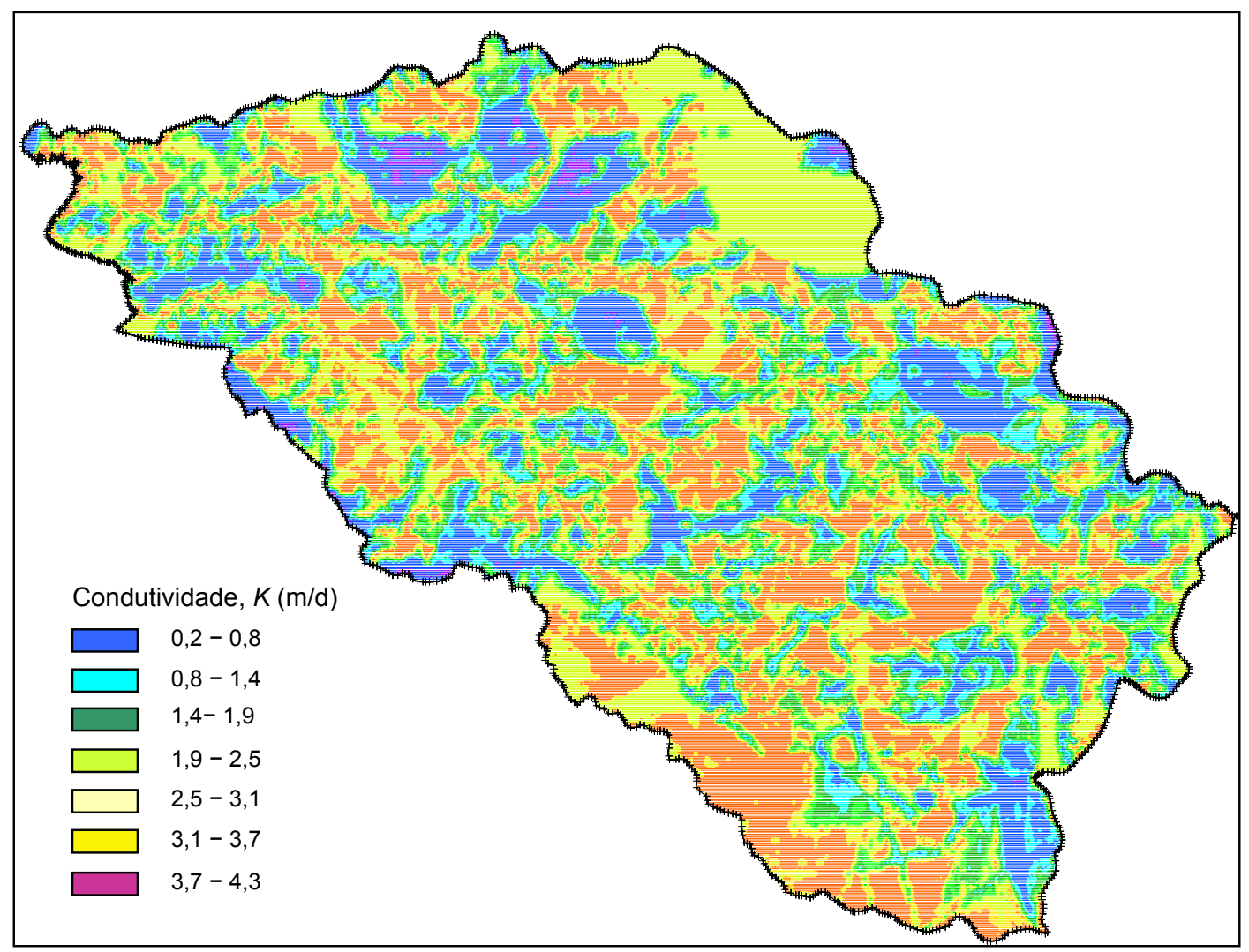

Figura 49 - Distribuição da condutividade hidráulica na área de estudo

A recarga total $\left(R_{t}\right)$ obtida para a área das bacias foi de $297,6 \mathrm{~mm}$. Couberam os seguintes valores percentuais de recarga por formação ou estrutura geológica: 53,8\%, Botucatu/Pirambóia, 20,5\%, arenito/basalto intercalados, 15,7\%, Serra Geral, 5,1\% Adamantina, 3,6\% Sedimentos da Serra de São Carlos e 1,3\%, Itaqueri. A descrição detalhada dos valores obtidos de recarga é apresentada adiante como resultados. 


\subsubsection{Análise de sensibilidade}

A análise de sensibilidade visou avaliar a influência individual dos parâmetros de ajuste de calibração (PACs) no processo de calibração do modelo, que tem como referências vazões de base e cargas hidráulicas.

$O$ efeito dos PACs foi avaliado em relação à sensibilidade de RMSEH e RMSEQ, Figura 50(a) e Figura 50(b), respectivamente. Do lado esquerdo da Figura 50 são avaliados os efeitos das recargas ( $R \_A l$ a $R \_S S C$ ), e do lado direito, o efeito das cargas de interação rio-aqüífero, condutividade e vazão lateral $\left(h_{R-A}, K\right.$ e $\left.Q_{L}\right)$.

O comportamento entre as variações de RMSEs e PACs mostrou-se predominantemente linear e simétrico em relação ao eixo zero de variação dos PACs, exceto ligeiramente pelo comportamento de $h_{R-A}$ e $K$. Contudo, valores médios foram utilizados para quantificar as variações entre RMSEs e PACs.

Diferentemente dos demais PACs, as cargas de interação rio-aqüífero $\left(h_{R-A}\right)$ foram permitidas variar apenas de $\pm 10 \%$. Isso se deve ao fato desta variação ser próxima à variação dos erros estimados para estas cargas ( 6 a 13\%, atribuídos à soma dos erros da superfície potenciométrica e cotas altimétricas). Além disso, devido a sua forte influência sobre as cargas hidráulicas calculadas (Figura 50(a)), a imposição de uma variação maior que $\pm 10 \%$ gera cargas hidráulicas calculadas de valor inferior à cota de base do aqüífero em algumas células na malha do modelo numérico (células secas), o que, em geral, faz com que a solução do sistema de equações não convirja.

Em relação à sensibilidade de RMSEH, os PACs, na seqüência de maior para menor influência, são: $h_{R-A}, K, R \_S S C, R \_A D, R \_S G, R \_A l, R \_B P, R \_I T$ e $Q_{L}$. Entre as recargas, o fator entre as contribuições de maior e menor influência é de 18,4 (razão entre as variações das RMSEHs de $R \_S S C$ e $R \_I T$ ) e desviopadrão médio das variações de RMSEH, ${ }^{1} \sigma_{ \pm 10}^{\mathrm{H}}=3$,8. Para todo o conjunto de PACs, o fator é de 187,6 (razão entre as variações das RMSEHs de $h_{R-A}$ e $Q_{L}$ ) e $\sigma_{ \pm 10}^{\mathrm{H}}=66,3$. Esse fator é muito superior aos demais fatores calculados para os demais PACs (o segundo maior fator, entre as variações das RMSEHs de $K$ e $Q_{L}$,

\footnotetext{
${ }^{1}$ Média dos desvios-padrão das variações de RMSEH para variações de PACs em -10 e +10\%
} 
é 19,3). Este comportamento de sensibilidade atribui às variações de RMSEH a característica de avaliar essencialmente a influência das cargas $h_{R-A}$ sobre o modelo.
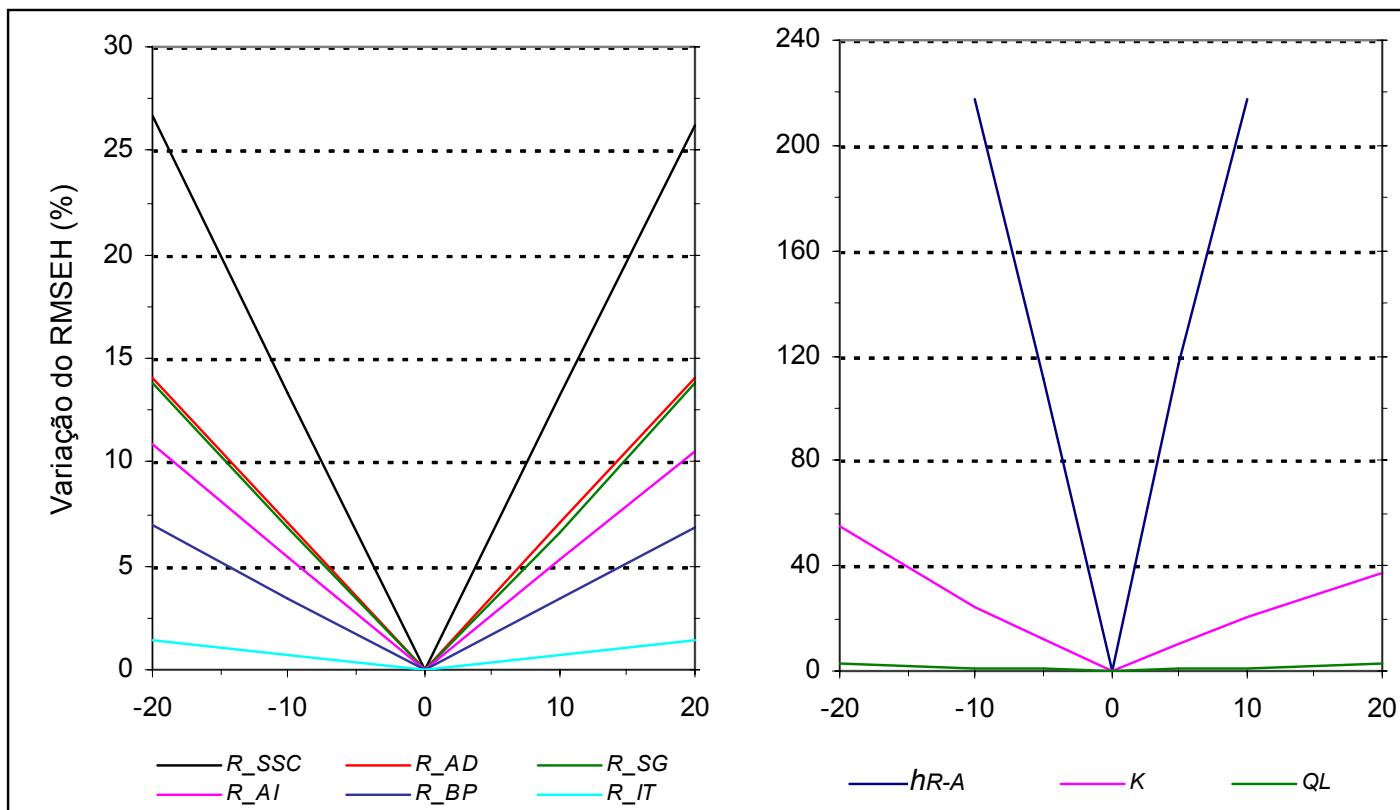

(a) Variação dos parâmetros de ajuste de calibração (\%)
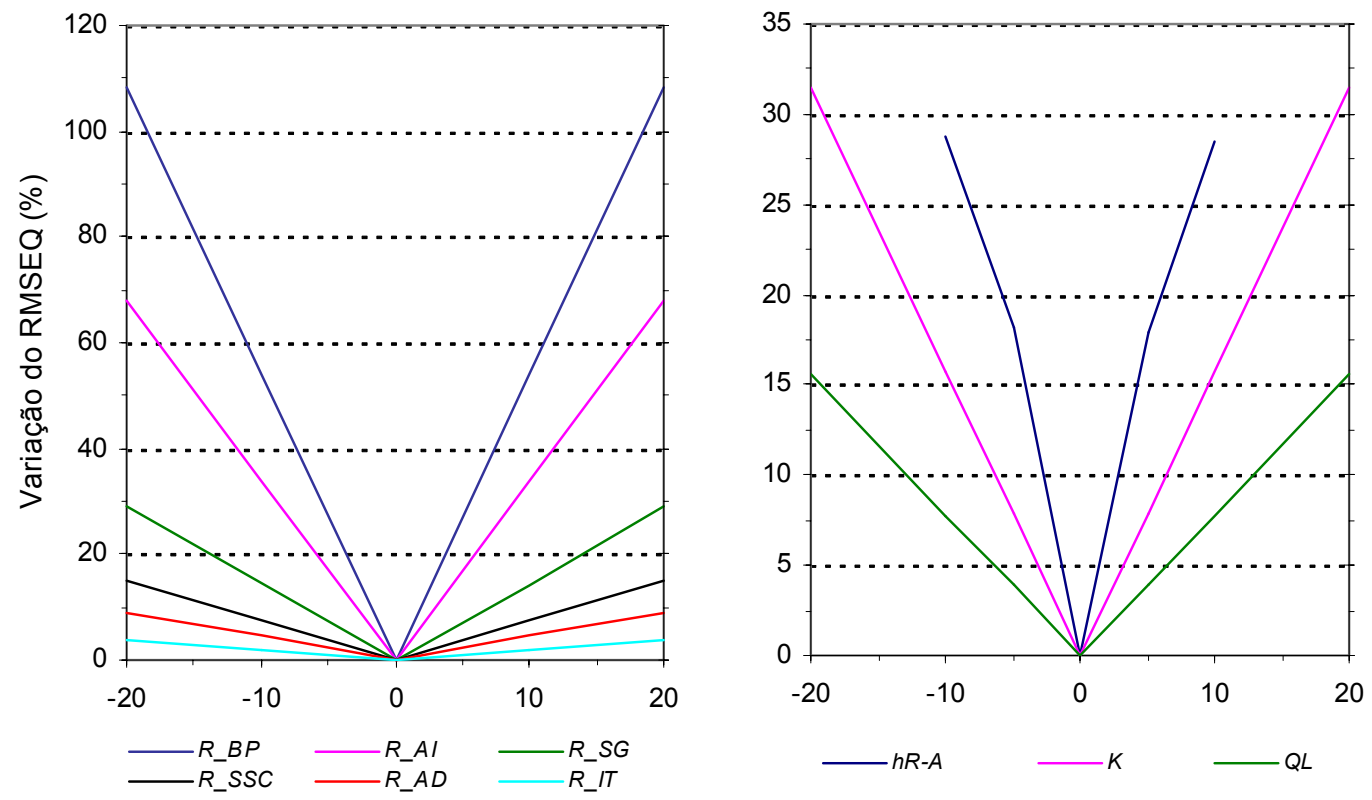

(b)

Variação dos parâmetros de ajuste de calibração (\%)

Figura 50 - Influência dos parâmetros de ajuste de calibração (PACs) em relação aos valores de RMSEH (a) e RMSEQ (b). 
Em relação à sensibilidade de RMSEQ, os PACs, na seqüência de maior para menor influência, são: $R \_B P, R \_A l, h_{R-A}, K, R \_S G, Q_{L}, R \_S S C, R \_A D$ e $R \_I T$. Entre as recargas, o fator entre as contribuições de maior e menor influência é de 30,4 (razão entre as variações das RMSEQs de $R \_B P$ e $R \_I T$ ), e correspondente $\sigma_{ \pm 10}^{Q}=18,8$. Esse fator é também o maior para todo o conjunto de PACs, que possui $\sigma_{ \pm 10}^{Q}=16,1$. Este comportamento de sensibilidade atribui uma influência mais igual dos PACs sobre as vazões de base que sobre as cargas hidráulicas.

As recargas influenciam predominantemente mais as vazões de base que as cargas hidráulicas. Isso é mensurado pela razão entre a variação de RMSEQ e RMSEH das recargas R_BP, R_AI, R_IT e R_SG, respectivamente, 15,6, 6,4, 2,5 e 2,1. A exceção coube às recargas R_AD e R_SSC, apresentando ambas, razão de 0,6 . Isso se deve possivelmente à heterogeneidade da distribuição dos poços de monitoramento, utilizados como conjunto-referência das cargas hidráulicas na calibração do modelo, cabendo à Formação Adamantina e Sedimentos da Serra de São Carlos uma quantidade relativamente elevada de poços (28 e 20, respectivamente) em comparação às demais formações e estrutura: Botucatu/Pirambóia, Serra Geral, arenito/basalto intercalados e Itaqueri (com 23, 18, 8 e 2 poços, respectivamente).

A influência das recargas sobre RMSEH mostrou-se significativamente relacionada à distribuição dos poços de monitoramento, enquanto que a influência das recargas sobre RMSEQ mostrou-se significativamente relacionada à magnitude das recargas relativas das formações. Estas características, juntamente com a descrita no parágrafo anterior, atribuem à sensibilidade RMSEQ uma melhor capacidade de avaliar o efeito das recargas.

A influência da condutividade mostrou-se significativa em relação às sensibilidades de RMSEH e RMSEQ, com predominância na primeira, e a vazão lateral mostrou-se significativa em relação à sensibilidade de RMSEQ, exercendo influência de pouco significado sobre o conjunto das cargas hidráulicas calculadas. A utilização conjunta de vazões de base e cargas hidráulicas na calibração do modelo resultou, de modo geral, na avaliação significativamente mais adequada da influência dos PACs em um dos conjuntos. 


\section{RESULTADOS E DISCUSSÃO}

Os resultados principais obtidos com a calibração do modelo foram as taxas de recarga do aqüífero (através das formações e estruturas geológicas), as drenagens através do fluxo de base ao longo dos rios e o fluxo lateral através do contorno do aqüífero. Dentre as drenagens por fluxo de base, foram determinadas as vazões de entrada e saída, correspondentes às regiões em que o aqüífero é carregado e descarregado, respectivamente.

Todos os valores de fluxo foram expressos para períodos anuais.

A recarga total $\left(R_{t}\right)$, obtida para a área das bacias foi de $297,6 \mathrm{~mm}$, distribuída entre as formações e estruturas geológicas e determinada pela relação

$$
R_{t}=\frac{1}{A_{t}} \sum_{i}^{n} R_{i} \cdot A_{i}
$$

cujos parâmetros estão indicados na Tabela 15.

Tabela 15 - Valores anuais de recarga do Aqüífero Guarani, distribuídos por formações e estruturas geológicas

\begin{tabular}{l|c|c|c|c|c}
\hline \multirow{2}{*}{$\begin{array}{l}\text { Formações e estruturas } \\
\text { geológicas }\end{array}$} & \multicolumn{2}{|c|}{$\begin{array}{c}\text { Recarga } \\
R_{i}(\mathrm{~mm})\end{array}$} & \multicolumn{2}{|c}{ Área } & \multicolumn{3}{c}{ Recarga } \\
\cline { 3 - 6 } & $A_{i}\left(\mathrm{~km}^{2}\right)$ & $(\%)$ & $\left(10^{8} \mathrm{~m}^{3}\right)$ & $(\%)$ \\
\hline \hline Botucatu/Piramboia & 465 & 2.321 & 34,4 & 10,793 & 53,8 \\
\hline Arenito/basalto intercalados & 530 & 778 & 11,5 & 4,123 & 20,5 \\
\hline Serra Geral & 215 & 1.470 & 21,8 & 3,161 & 15,7 \\
\hline Adamantina & 75 & 1.358 & 20,1 & 1,019 & 5,1 \\
\hline $\begin{array}{l}\text { Sedimentos da Serra de São } \\
\text { Carlos }\end{array}$ & 305 & 237 & 3,5 & 0,723 & 3,6 \\
\hline \begin{tabular}{l} 
Itaqueri \\
\hline \hline Totais
\end{tabular} & 45 & 584 & 8,7 & 0,263 & 1,3 \\
\hline
\end{tabular}


Os resultados obtidos de recarga indicam que, na área das bacias, esta se processa essencialmente na região de afloramento do aqüífero, através das formações identificadas como Botucatu/Pirambóia e arenito/basalto intercalados, correspondendo a $74,3 \%$ da recarga total. Este valor é significativamente distinto da proporção entre área de afloramento e área total do aqüífero (aproximadamente 46\%).

A recarga por zona variou de 530 a $45 \mathrm{~mm}$ respectivamente para as regiões de arenito/basalto intercalados e de Formação Itaqueri.

A recarga da região arenito/basalto intercalados $(530 \mathrm{~mm})$, superior a da região Botucatu/Pirambóia $(465 \mathrm{~mm}$ ) reforça a suposição, empregada pelo modelo conceitual, de que o contato extensivo entre arenito e basalto determina uma situação diferenciada de infiltração e recarga, que no caso dos resultados obtidos, aumenta a taxa média de recarga.

Entre as menores taxas de recarga, estão as obtidas através das formações Adamantina e Itaqueri, 75 e $45 \mathrm{~mm}$, respectivamente. Essas taxas de recarga sugerem neste sistema aqüífero um fluxo com comportamento quase exclusivamente horizontal que drena as nascentes dos rios, sobrando pouca água para percolar verticalmente através do basalto. Além disso, essas formações possuem relativamente maior teor de argila, o que acarreta em valores mais baixos de condutividade hidráulica.

As áreas de afloramento da Formação Serra Geral apresentam valores de recarga absoluto e relativo elevados, $215 \mathrm{~mm}$ e $15,7 \%$, respectivamente, considerando-se tratar de basaltos e por representar um aquitardo. Contrariamente a estes resultados, está o fato dos basaltos serem derrames de rochas consolidadas, e a favor está o fato de cursarem freqüentemente com fissuras e fraturas, representando um meio de drenança ao Aqüífero Guarani subjacente.

Os sedimentos da Serra de São Carlos, apesar de classificados como mais recentes que os da Formação Bauru, também são genericamente tratados como pertencentes ao sistema aqüífero Bauru-basaltos. Apesar disso, o valor obtido de taxa de recarga (305 mm) é significativamente mais elevado que os referentes às formações Adamantina e Itaqueri. Como possível explicação desse resultado, está o fato destes sedimentos serem menos consolidados e ocorrerem encravados principalmente entre as regiões de arenito/basalto intercalados e 
Botucatu/Pirambóia (Figura 13). Além disso, existem registros estratigráficos de ausência da Formação Serra Geral entre os sedimentos da Serra de São Carlos e a Formação Botucatu (PERRONI, 2005). Isso é verificado também em dados de poços, p.ex., poço 115, na região sudeste da cidade de São Carlos - poço de 209 $\mathrm{m}$ de profundidade, com $60 \mathrm{~m}$ iniciais de Formação Adamantina e o restante inteiramente na Formação Botucatu (Anexo A).

A partir dos dados da Tabela 9 (áreas de drenagem) e Tabela 14 (vazões), é realizado um balanço hídrico no domínio sobre o Aqüífero Guarani, abrangendo a área de drenagem das bacias, referente ao conjunto das estações fluviométricas E1 e E7 (5935 $\left.\mathrm{km}^{2}\right)$. Este primeiro balanço visa obter a evapotranspiração média $(E T)$ como estimativa:

$$
Q_{s}+Q_{b B / b}+R_{t}=P-E T
$$

no qual $Q_{s}=Q_{t}-Q_{b t}=89,6 \mathrm{~mm}$ e $Q_{b B / b}=69,2 \mathrm{~mm}$ são, respectivamente, os escoamentos superficial, total, de base total e de base das formações do sistema Bauru-basaltos, como definidos na seção $4.1 ; R_{t}=297,6 \mathrm{~mm}$ é a recarga total e $P=1371,2 \mathrm{~mm}$ é a precipitação média considerada para a área das bacias. Deste balanço, é obtida a evapotranspiração média, $E T=914,8 \mathrm{~mm}$. Este valor é significativamente próximo ao apresentado por BRAGA et al. (1991), 980 mm, para a evapotranspiração média nas regiões de precipitação em torno de 1400 $\mathrm{mm}$, na parte brasileira do Aqüífero Guarani.

Como forma de contornar a ausência de dados fluviométricos no exutório das bacias estudadas, o mesmo balanço anterior é aplicado agora à área total das bacias $\left(6748 \mathrm{~km}^{2}\right.$ ) visando estimar o escoamento superficial (do sistema Baur-basaltos e Formação Botucatu) e de base (do sistema Baur-basaltos), conjuntamente representados por $Q_{s b B / b B(c o m p)}$, na área de drenagem complementar à do balanço anterior $\left(813 \mathrm{~km}^{2}\right)$, Figura 51 .

$$
Q_{s(E 1 E 7)}+Q_{b B / b(E 1 E 7)}+Q_{s b B / b B(c o m p)}+R_{t}=P-E T
$$


no qual $Q_{s(E 1 E 7)}$ e $Q_{b B / b(E 1 E 7)}$ são, respectivamente, $78,8 \mathrm{~mm}$ e $60,9 \mathrm{~mm}$, o escoamento superficial total e o escoamento de base do sistema Bauru-basaltos (Tabela 14), captados pela área de drenagem referente às estações E1 e E7; $R_{t}=$ $297,6 \mathrm{~mm}$ e $P-E T=456,4 \mathrm{~mm}$. Deste segundo balanço, é obtido $Q_{s b B / b B(c o m p)}=$ $19,1 \mathrm{~mm}$.

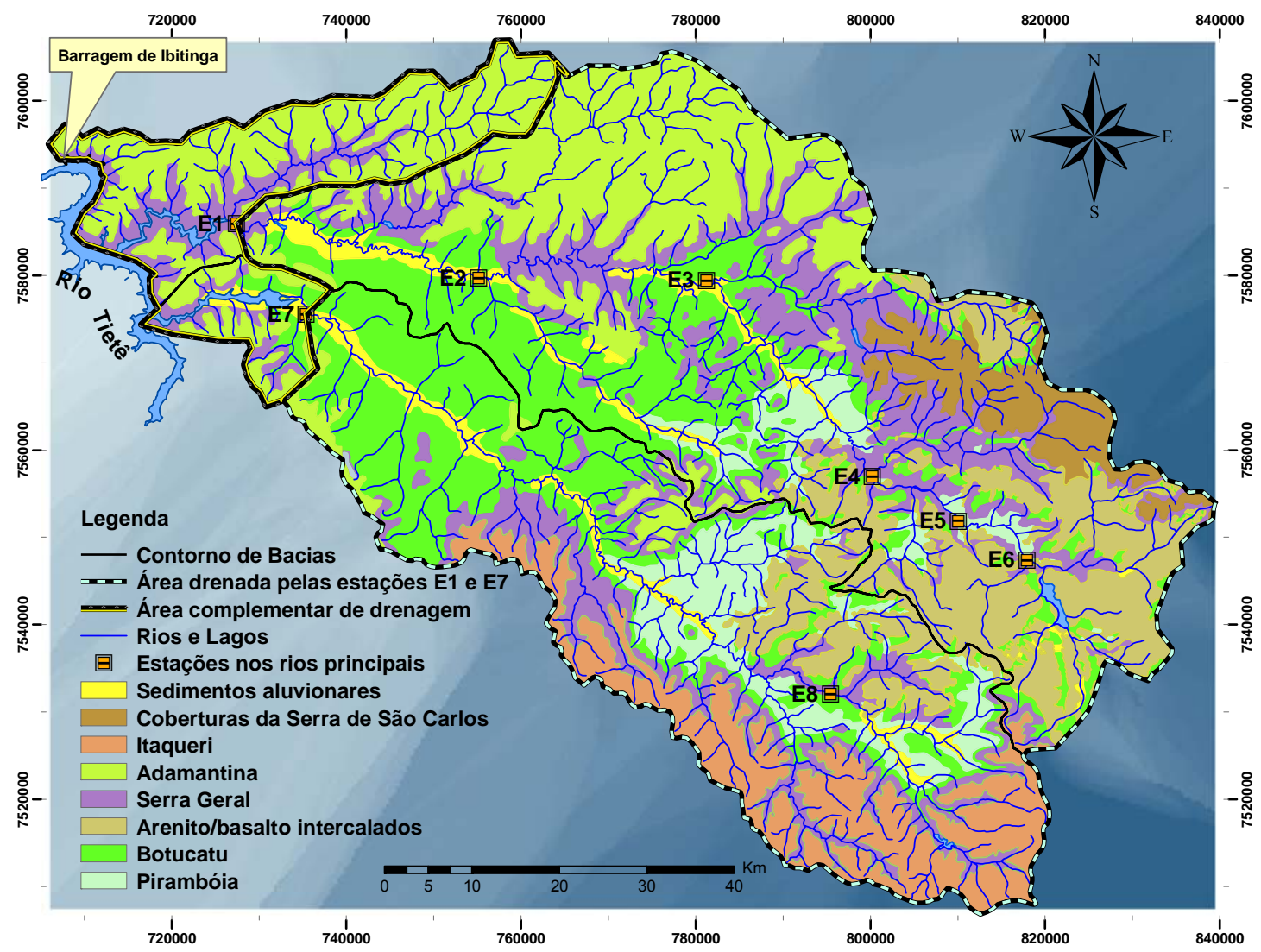

Figura 51 - Localização da área complementar de drenagem, em relação à área de drenagem correspondente às estações fluviométricas E1 e E7

Um terceiro balanço é aplicado simultaneamente ao domínio do Aqüífero Guarani (Formações Bortucatu/Pirambóia) e sobre o Aqüífero Guarani (sistema Bauru-basaltos), abrangendo a área total de drenagem das duas bacias (6748 $\left.\mathrm{km}^{2}\right)$, visando estimar a descarga profunda $\left(Q_{p r o}\right)$ :

$$
Q_{t(E 1 E 7)}+Q_{s b B / b B(c o m p)}+Q_{b G(c o m p)}+Q_{L}+Q_{p r o}=P-E T .
$$

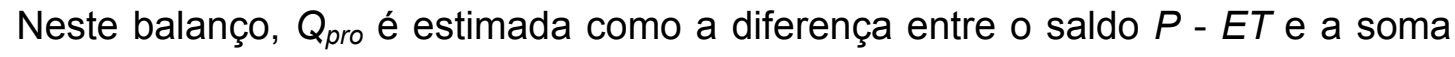
dos escoamentos estimados pelo modelo $\left(Q_{t(E 1 E 7)}+Q_{s b B / b B(c o m p)}+Q_{b G(c o m p)}+Q_{L}\right)$, 
no qual $Q_{t(E 1 E 7)}=337,1 \mathrm{~mm}$ é o escoamento total captado pela área de drenagem referente às estações E1 e E7 (Tabela 14); $Q_{s b B / b B(c o m p)}=19,1 \mathrm{~mm} ; Q_{b G(c o m p)}=$ $21,5 \mathrm{~mm}$ é o escoamento de base proveniente do Guarani na região complementar de drenagem, determinado no modelo numérico pelas vazões obtidas da aplicação das condições de carga constante nesta região; $Q_{L}=17,3$ $\mathrm{mm}$ é o escoamento lateral, determinado no modelo numérico pela aplicação da condição de vazão constante; $P$ - $E T=456,4 \mathrm{~mm}$. Deste balanço, é obtido $Q_{p r o}=$ $61,4 \mathrm{~mm}$.

Algumas simplificações foram utilizadas nos balanços anteriores:

a) no primeiro balanço, os valores médios de $P$ e $R_{t}$ foram considerados os mesmos quando considerada toda a área de estudo e quando considerada apenas a área de drenagem referente às estações fluviométricas E1 e E7. Favorável a essa simplificação é o fato da área complementar de drenagem representar apenas $12 \%$ da área total de estudo;

b) no primeiro e segundo balanços, são desconsideradas possíveis contribuições da descarga de poços do Guarani em $Q_{s}$. Favorável a essa simplificação é o fato da explotação por poços representar pequena parcela em relação à $Q_{s}$ (em torno de $11 \%$ ), bem como, parte indeterminada desta contribuição ser ainda evapotranspirada;

c) no segundo e terceiro balanços, a evapotranspiração média $E T$ obtida para a área de drenagem referente às estações fluviométricas E1 e E7 foi mantida para a área total das bacias. Favorável a essa simplificação é o fato da área complementar de drenagem representar pequena parcela da área total das bacias;

d) em todos os três balanços, são desconsideradas possíveis contribuições do Guarani nas vazões de base das bacias-referência do sistema Bauru-basaltos. Favorável a essa simplificação é o fato da pequena incidência de interação rioaqüífero nestas bacias, identificada apenas na parte jusante da bacia-referência correspondente à estação E9 (Figura 30 e Figura 37).

O valor obtido para a vazão de base positiva ou injeção, que recarrega o

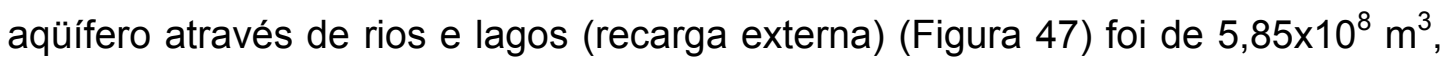
correspondente a $29,1 \%$ da recarga total $\left(20,08 \times 10^{8} \mathrm{~m}^{3}\right)$ O valor significativo deste tipo de recarga e a sua localização na área das bacias são importantes aos 
estudos que visam à preservação e uso racional do aqüífero, uma vez que, nestas regiões o aqüífero é potencialmente mais vulnerável.

A inclusão dos poços foi realizada no modelo calibrado (sem poços). Desconsiderando-se o efeito dos poços sobre os valores anteriormente obtidos de

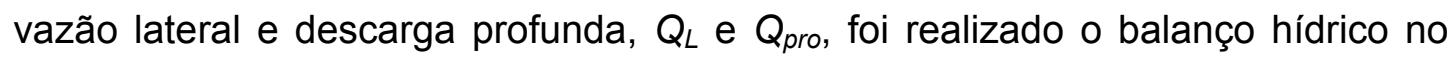
domínio do Aqüífero Guarani (meio saturado) para a área total das bacias. Neste balanço, o efeito dos poços foi atribuído exclusivamente sobre as vazões de base. Os componentes de entrada e saídas do balanço são descritos na Tabela 16.

Tabela 16 -Balanço hídrico com valores anuais obtidos para o Aqüífero Guarani para a área total de estudo

\begin{tabular}{l|c|c|c}
\hline Entrada & $\left(10^{8} \mathrm{~m}^{3}\right)$ & $(\mathrm{mm})$ & $(\%)$ \\
\hline \hline Recarga $\left(R_{t}\right)$ & 20,08 & 297,6 & 100 \\
\hline Saídas & $\left(10^{8} \mathrm{~m}^{3}\right)$ & $(\mathrm{mm})$ & $(\%)$ \\
\hline \hline Rios e lagos $\left(Q_{b}\right)$ & 14,09 & 208,8 & 70,2 \\
\hline Descarga profunda $\left(Q_{\text {pro }}\right)$ & 4,14 & 61,4 & 20,6 \\
\hline Fluxo lateral $\left(Q_{L}\right)$ & 1,17 & 17,3 & 5,8 \\
\hline Poços $\left(Q_{P}\right)$ & 0,68 & 10,1 & 3,4 \\
\hline
\end{tabular}

O balanço hídrico, esquematizado entre entradas e saídas (Tabela 16), possui a recarga como única entrada, e como saídas, o escoamento de base $\left(Q_{b}\right)$, igual a $70,2 \%$ da recarga total $\left(R_{t}\right)$, e o restante, dividido entre a descarga profunda $\left(Q_{\text {pro }}\right)$, fluxo lateral $\left(Q_{L}\right)$ e explotação por poços $\left(Q_{P}\right)$. Esse resultado indica que o Aqüífero Guarani na área de estudo essencialmente drena a sua recarga através dos rios. O valor de $208,8 \mathrm{~mm}$, obtido para a descarga através de rios e lagos, concorda com o valor apresentado por REBOUÇAS (1976), que atribui a esta descarga $15 \%$ da precipitação média em áreas de afloramento do aqüífero - o que corresponderia, na área total de estudo, a aproximadamente 206 $\mathrm{mm}$. Isso atribui ao sistema de recarga, na área de estudo, característica de recarga essencialmente de regiões onde o aqüífero é aflorante.

A descarga profunda constitui a segunda maior saída. Ela corresponde à parte da recarga que deixa o aqüífero através da sua região principal de descarga, próxima ao Rio Tietê. Ela pode ser drenada através dos basaltos 
fissurados e com intrusões de arenitos existentes nesta região, bem como, através da estrutura do Permiano que compõe a base do aqüífero, sendo esta última contribuição provavelmente menor que a anterior devido à baixa condutividade atribuída a esta estrutura.

O escoamento lateral constitui a terceira maior saída. Ele é a parte da recarga que deixa o aqüífero, se transpondo ao o domínio de outras bacias através do contorno lateral da área de estudo (Figura 42). Essas saídas acontecem à leste e sul-sudeste da área de estudo na direção respectivamente das bacias do Rio Piracicaba e rios Jaú e Piracicaba. Essa estimativa é reforçada pela boa coincidência dos níveis estáticos entre os conjuntos estimado e calculado, nas proximidades dos trechos de fluxo lateral (Figura 45), contudo, a proximidade de poços próximos à saída leste (Figura 18) contribui desfavoravelmente para a garantia desta estimativa.

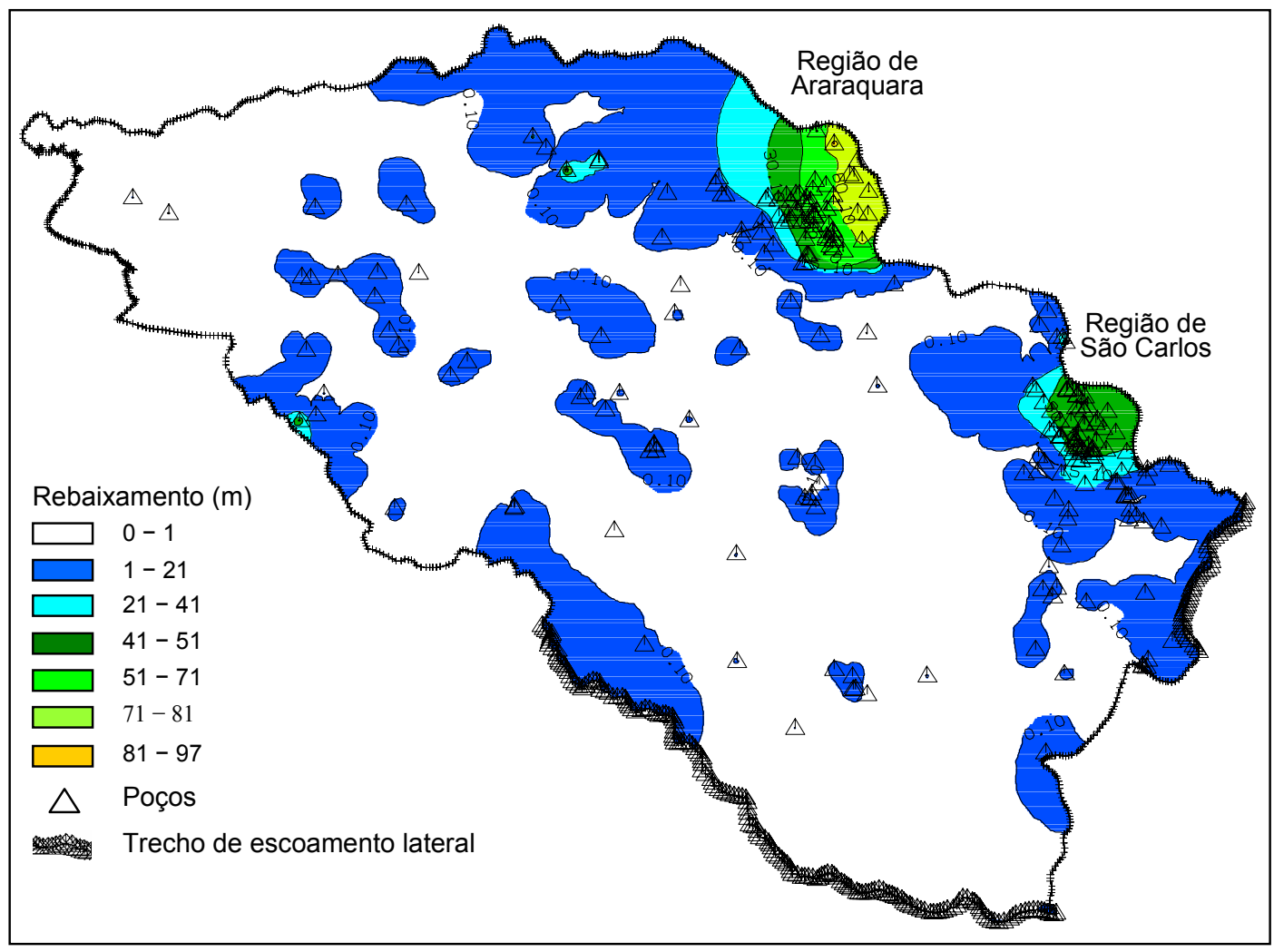

Figura 52 - Efeito dos poços sobre os níveis estáticos - rebaixamento da carga hidráulica

Os poços são a menor das saídas. Apesar disso, a ação conjunta local destes poços em algumas regiões, como nas proximidades das cidades de 
Araraquara e São Carlos, mostra efeitos sobre o nível estático, com tendência regional. Tal avaliação decorre da simulação do efeito dos poços em relação aos níveis estáticos do modelo calibrado. A simulação do rebaixamento da carga hidráulica, em relação à situação sem poços, é apresentada na Figura 52.

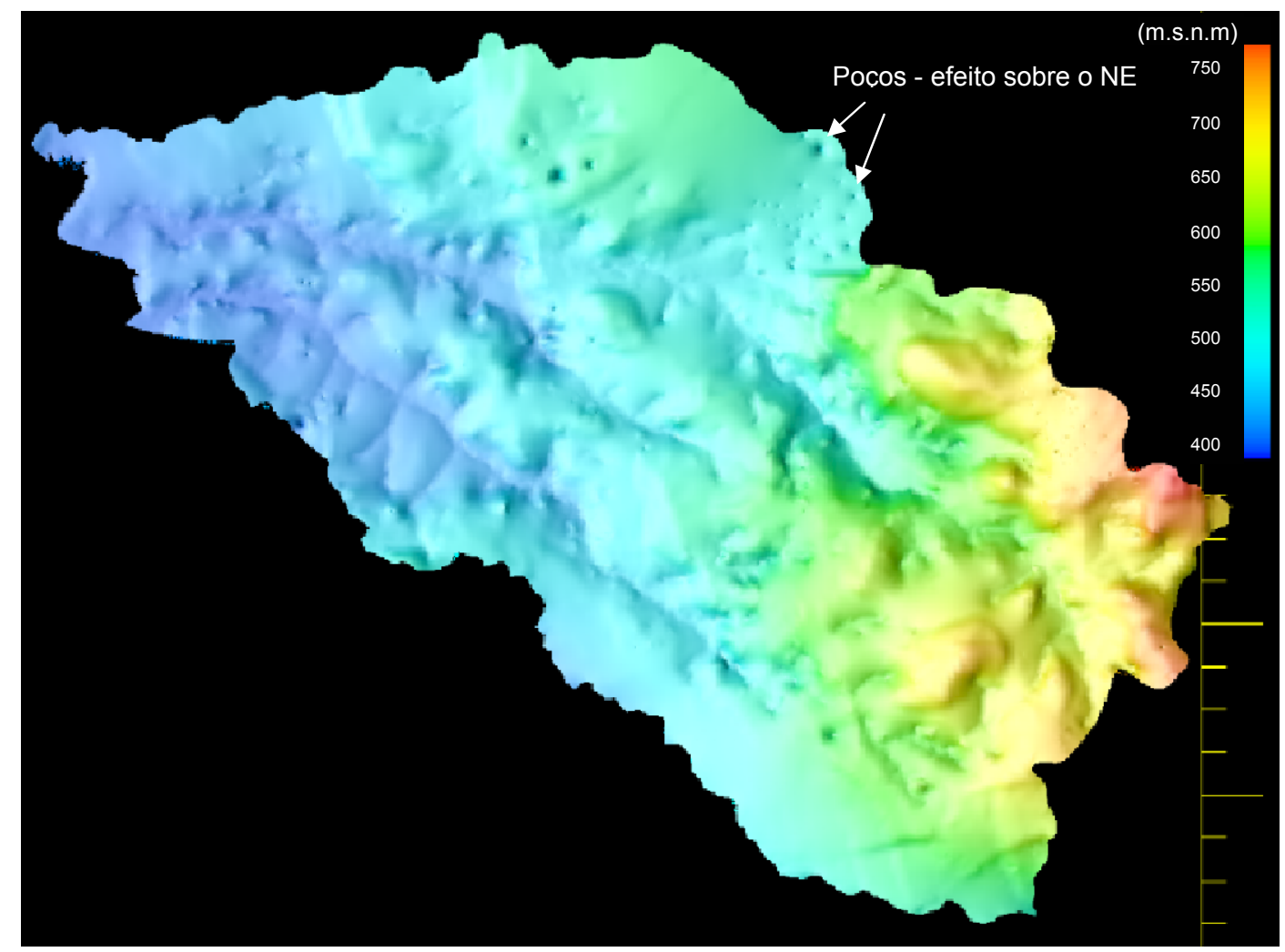

Figura 53 - Superfície piezométrica do Aqüífero Guarani (cotas em m.s.n.m) e o efeito local de poços sobre o rebaixamento dos níveis estáticos (NE)

Na região de Araraquara, o rebaixamento simulado é na sua maior extensão inferior a $41 \mathrm{~m}$, mas com regiões alcançando até $81 \mathrm{~m}$. Localmente, na base dos rebaixamento de alguns poços (Figura 53), valores mais elevados são obtidos alcançando rebaixamento máximo de $97 \mathrm{~m}$. Na segunda maior região de rebaixamentos, região de São Carlos, são obtidos rebaixamentos de até $51 \mathrm{~m}$, que apesar de menos intensos que na região anterior, se estende até o leste da área de estudo, na região de Itirapina. Tomando-se como exemplo a região de Araraquara, os achados são em boa proporção concordantes com a campanha de medições de níveis em alguns poços dessa região. Considerando-se o valor máximo medido de rebaixamento do nível estático, $50 \mathrm{~m}$, e que são comuns rebaixamentos de $25 \mathrm{~m}$ do nível dinâmico para poços nessa região, obtem-se um 
rebaixamento total de $75 \mathrm{~m}$. O que é um valor significativamente representativo dos valores simulados, sobretudo considerando-se o pequeno número de medições nessa região (cinco poços).

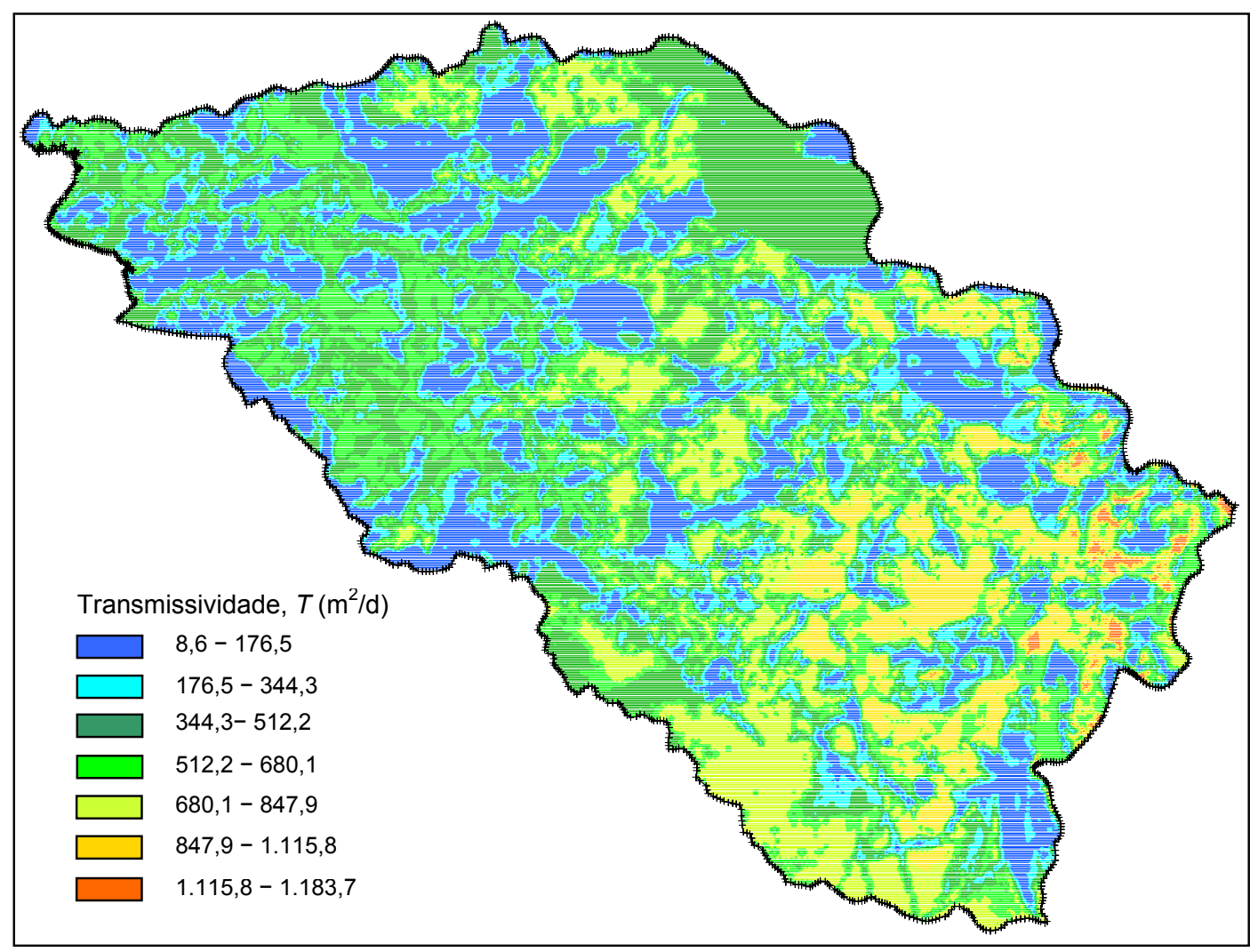

Figura 54 - Distribuição da transmissividade na área de estudo

A transmissividade para a área de estudo, obtida pela expressão $T=K \cdot b$, sendo $b$ a espessura saturada do aqüífero, alcançou valor médio ${ }^{1}$ de $411,6 \mathrm{~m}^{2} / \mathrm{d}$, variando entre 8,6 e $1.183,7 \mathrm{~m}^{2} / \mathrm{d}$ (Figura 54). O valor médio obtido está dentro dos limites mais comumente aceitos para o Aqüífero Guarani, 150 a $800 \mathrm{~m}^{2} / \mathrm{d}$ (BORGHETTI et al., 2004), contudo, os valores extremos obtidos ultrapassam os valores de mínimo e máximo esperados, indicados nos referidos trabalhos, 17 a $800 \mathrm{~m}^{2} / \mathrm{d}$ (BORGHETTI et al., 2004; IPT, 2003; CORRÊA, 1995; DAEE, 1974) e 2,4 a $552 \mathrm{~m}^{2} / \mathrm{d}$ (para a Formação Botucatu, ARAÚJO et al., 1999). Isso é atribuído ao fato dos valores obtidos de transmissividade serem valores pontuais, calculados para toda a área de estudo, enquanto os da bibliografia refletem

\footnotetext{
${ }^{1}$ Média ponderada em relação às áreas das células que compõem a malha do modelo numérico.
} 
valores tomados em poucos pontos, obtidos originalmente de testes de bombeamento e, ainda, ao fato do modelo poder, localmente, apresentar resultados não consistentes. Entretanto, os valores de transmissividade acima dos $800 \mathrm{~m}^{2} / \mathrm{d}$ ocorrem em menos de $10 \%$ da área das bacias.

O modelo conceitual que utilizou as formações e estruturas geológicas como recarga foi capaz de representar satisfatoriamente a recarga e o sistema de fluxo do aqüífero, baseado nas vazões de base e cargas hidráulicas, utilizadas como referência. Isso é verificado por meio dos bons resultados obtidos de $R^{2} \mathrm{e}$ correspondente coeficiente de inclinação, e da sensibilidade dos PACs na calibração do modelo. Contudo, as estimativas obtidas são de aspecto regional para o domínio das bacias.

A complexidade hidrogeológica da área de estudo e os erros associados aos dados do modelo impõe características localizadas que não são representadas satisfatoriamente pelo modelo. Como exemplo deste comportamento, é o fato das cargas de interação rio-aqüífero $\left(h_{R-A}\right)$, que uma vez postas a variar na faixa de erro estimado (até 13\%), gera rebaixamentos do nível estático abaixo da base do aqüífero em algumas regiões onde o erro absoluto estimado $\left(\Delta h_{R-A}\right)$ é inferior à espessura do aqüífero. Assim, na análise de sensibilidade, a avaliação do referido parâmetro é possível apenas em até 10\%. Esse comportamento é uma indicação de inconsistência na atribuição de valores locais de condutividade, recarga ou descarga e características dimensionais do aqüífero. 


\section{CONCLUSÕES}

Este trabalho estimou a recarga e o sistema de fluxo do Aqüifero Guarani no âmbito das bacias dos rios Jacaré-Guaçu e Jacaré-Pepira por meio de um modelo numérico bi-dimensional, heterogêneo, em regime estacionário. Para isso, foi realizado um extenso levantamento de dados com suporte SIG e estabelecido um modelo conceitual que considerou os principais fenômenos encontrados na área de estudo, envolvendo inicialmente a recarga, descarga pelos rios e fluxo lateral. Posteriormente, após a calibração e análise de sensibilidade do modelo, foi avaliada a interferência de poços sobre os níveis estáticos e estimada a descarga profunda por meio de balanço hídrico.

A estratégia adotada pelo modelo conceitual estabeleceu zonas de recarga correspondentes a seis formações e estruturas geológicas na área de estudo, perfazendo zonas de aqüífero livre e semiconfinado. Por meio de sua aplicação, foi alcançado o objetivo central deste trabalho, de estimar a recarga e o sistema de fluxo do Aqüífero Guarani na área de estudo, apresentando os seguintes resultados em relação às recargas e descargas:

a) Existência de significativa interação entre as recargas provenientes das duas bacias, e interação de fluxo subterrâneo lateral entre bacias circunvizinhas. Este achado não corrobora com a idéia de abordar, na região, o estudo de bacias hidrográficas como unidades hidrologicamente independentes.

b) A recarga se processa essencialmente através da região de afloramento do aqüífero $(74,3 \%$ da recarga total), sendo esta proporção significativamente distinta da proporção entre área de afloramento e área total (aproximadamente $46 \%)$.

c) A recarga por zona variou de 45 a $530 \mathrm{~mm}$, sendo as menores taxas atribuídas às formações Adamantina e Itaqueri, e as maiores, às formações Botucatu e Pirambóia aflorantes, que apresentaram aumento dessas taxas 
quando cursando na presença de basaltos, em região denominada de arenito/basaltos intercalados.

d) O Aqüífero Guarani na área de estudo essencialmente drena a sua recarga através dos rios como escoamento de base $(70,2 \%$ da recarga total), cabendo à descarga profunda e descarga lateral contribuições sensivelmente menores $(20,6 \%$ e $5,8 \%$, respectivamente) e o restante $(3,4 \%)$, atribuído à ação de poços.

e) Apesar do aqüífero essencialmente abastecer os rios, o valor obtido para a vazão de base positiva (injeção do aqüífero) é significativo $(29,1 \%$ da recarga total), uma vez que, os trechos nos quais ocorre injeção o aqüífero é potencialmente mais vulnerável.

Apesar dos poços se constituírem na menor das saídas, a ação local conjunta destes, em algumas regiões, como nas proximidades das cidades de Araraquara e São Carlos, mostrou rebaixamentos dos níveis estáticos com tendência regional.

A complexidade hidrogeológica da área de estudo e os erros associados aos dados do modelo desenvolvido impõem características localizadas que não são representadas satisfatoriamente pelo modelo, atribuindo a este uma aplicação, sobretudo, regional no âmbito das bacias estudadas.

Como sugestões para ampliar o estudo sobre o sistema de fluxo do aqüífero no âmbito das bacias, sugere-se o estudo do efeito hidráulico da intercalação dos basaltos no arenito, preponderante na região montante das bacias, e o estudo sobre o comportamento do aqüífero no seu exutório (incluindo a obtenção de dados fluviométricos nas saídas das bacias), visando investigar a interação entre o aqüífero, sua camada semiconfinante e sua descarga profunda na bacia do Tietê. $O$ entendimento melhor destas questões representaria significativa contribuição ao modelo elaborado neste trabalho. 


\section{REFERÊNCIAS}

ALLISON, G. B.; COOK, P. G.; BARNETI, S. R.; WALKER, G. R.; JOLLY, I. D.; HUGHES, M. W. (1990). Lanclarence and river salinisation in the western Murray Basin, Australia. Journal of Hydrology, v.119, p. 1-20.

ALMEIDA, F.F.M.; BARBOSA, O. (1953). Geologia das quadrículas de Piracicaba e Rio Claro, Estado de São Paulo. Rio de Janeiro: DNPM/DGM. Boletim 143.

ANA - AGÊNCIA NACIONAL DE ÁGUAS. (2005). Disponibilidade e demandas de recursos hídricos no Brasil. 134 p. Agência Nacional de Águas, Brasília - DF.

ANDERSON, M. P.; WOESSNER, W. W. (1992). Applied Groundwater Modeling Simulation of Flow and Advective Transport. San Diego, USA: Academic Press. $381 \mathrm{p}$.

ARAÚJO, L. M.; FRANÇA, A. B.; POTTER, P. E. (1999). Hydrogeology of the Mercosul aquifer system in the Paraná and Chaco-Paraná Basins, South America, and comparison with the Navajo-Nugget aquifer system, USA. Hydrogeology Journal, v. 7(3), p. 313-336

ARNOLD, J. G.; ALLEN, P. M.; MUTTIAH, R.; BERNHARDT, G. (1995). Automated base flow separation and recession analysis techniques. Ground Water, v. 33, p. 1010-1018.

ARNOLD, J. G.; ALLEN, P. M. (1999). Automated methods for estimating baseflow and groundwater recharge from streamflow records. Journal of the American Water Resources Association, v. 35, p. 411-424. 
BEAR, J. (1979). Hydraulics of Groundwater. New York: McGraw-Hill. 569 p.

BORGHETTI, N. R. B.; BORGHETTI, J. R.; ROSA FILHO, E. F. (2004). Aqüífero Guarani - a verdadeira integração dos países do Mercosul. Curitiba: Nova Editora. 214 p.

BOUR, O.; DAVY, P. (1998). On the connectivity of three-dimensional fault networks. Water Resources Research, v. 34, p. 2611-2622.

BRAGA, B. P. F.; CONEJO, J. G. L.; PALOS, J. C. F. (1991). Balanço hídrico do Estado de São Paulo. Unesco, Montevidéu.

CAMPOS, H. C. N. S. (1999). Modelación conceptual y matamática del Acuífero Guaraní, Cono Sur. Mapa Hidrogeológico do Aqüífero Guarani. Acta Geológica Leopoldensia, v. 23(4), p. 3-50.

CEY, E. E; RUDOLPH, D. L.; PARKING, G. W.; ARAVENA, R. (1998). Quantifying Groundwater Discharge to a Small Perennial Stream in Southern Ontario, Canada. Journal of Hydrology, v. 210, p. 21-37.

CHANG, H. K. Uso atual e potencial do Sistema Aqüífero Guarani: atividade 3 do Projeto Aqüífero Guarani. Brasil: Agência Nacional de Águas, 2001. Disponível em: <http://www.ana.gov.br/guarani/gestao/gest_cbasico.htm>. Acesso em: 25 mar. 2004.

CHERKAUER, D.; McBRIDE, J. (1988). A Remotely-operated seepage meter for use in large lakes and rivers. Ground Water, v. 26, p. 165-177.

CONTIM NETO, D. (1987). Balanço hídrico em bacia hidrográfica situada em região de carga do aqüífero Botucatu. 130 p. Tese (Doutorado) - Escola de Engenharia de São Carlos, Universidade de São Paulo, São Carlos. 1987. 
COOK, P. G.; HATTON, T. J.; PIDSLEY, D.; HEREZEG, A. L.; HELD, A.; O'GRADY, A.; EAMUS, D. (1998). Water balance of a tropical woodland ecosystem, northern Australia: a combination of micro-meteorological, soil physical, and groundwater chemical approaches. Journal of Hydrology, v. 210, p. 161-177.

COOK, P. G.; WALKER, G. R.; BUSELLI, G. POTTS, I.; DODDS, A. R. (1992). Spatial variability of groundwater recharge in a semiarid region. Journal of Hydrology, v. 111, p. 195-112.

CORRÊA, U. M. P. (1995). Estudo das águas subterrâneas das bacias hidrográficas dos rios Jacaré-Guaçu e Jacaré-Pepira no Estado de São Paulo. 3 v, 107 p. Dissertação (Mestrado) - Escola de Engenharia de São Carlos, Universidade de São Paulo, São Carlos. 1995.

COTTAS, L.R., BARCELOS, J.H. (1981). Novas considerações sobre a geologia da região de Itaqueri da Serra. In: Simpósio Regional de Geologia, 3, Curitiba. Atas... Curitiba: SBG. v. 2, p. 70-76.

CUNHA, A. T. (2003). Estimativa experimental da taxa de recarga na zona de afloramento do Aqüifero Guarani, para a região de São Carlos - SP. 117 p. Dissertação (Mestrado) - Escola de Engenharia de São Carlos, Universidade de São Paulo, São Carlos. 2003.

DAEE - DEPARTAMENTO DE ÁGUAS E ENERGIA ELÉTRICA. (1974). Estudo de Águas Subterrâneas: Região Administrativa $n^{\circ} 6$, Ribeirão Preto. São Paulo: v. 4.

- (1998). Os aqüiferos Botucatu e Pirambóia no Estado de São Paulo: novos mapas de isóbatas do topo, espessura e nível d'água. São Paulo.

DNM - DEPARTAMENTO NACIONAL DE METEOROLOGIA - MINISTÉRIO DA AGRICULTURA E REFORMA AGRÁRIA, SECRETARIA NACIONAL DE IRRIGAÇÃO. (1992). Normas climatológicas, 1961-1990, Brasília, p. 1-84. 
De VRIES, J. J.; SIMMERS, I. 2002. Groundwater recharge: an overview of processes and challenges. Hydrogeology Journal, v. 10, p. 5-17.

DOMENICO, P. A. (1972). Concepts and Models in Groundwater Hydrology. New York : McGraw-Hill. 405 p.

ESRI. (2002). Software ARCVIEW . vs. 8.3. CA, USA. Manual Arcmap. 229 p.

FERNANDES, L.A. (1998). Estratigrafia e evolução geológica da parte oriental da Bacia Bauru (Ks, Brasil). 216 p. Tese (Doutorado) - Instituto de Geociências, Universidade de São Paulo, São Paulo. 1998.

FORTUNA, A. O. (2000). Técnicas computacionais para dinâmica dos fluidos. São Paulo : Edusp. 426 p.

FRANKE, O. L.; REILLY, T. E.; BENNETT, G. D. (1987). Definition of boundary and initial conditions in the analysis of saturated ground-water flow systems; an introduction US.Geological Survey, Techniques of Water-Resources Investigation, v. $5,15 \mathrm{p}$.

FREEZE, R. A; CHERRY, J. A. (1979). Groundwater. Prentice-Hall, Englewood Cliffs, NJ. 604 p.

FREITAS, A. L. S. de. (1996). Caracterização do aqüífero Botucatu na região do lixão de São Carlos. 113 p. Dissertação (Mestrado) - Escola de Engenharia de São Carlos, Universidade de São Paulo, São Carlos. 1996.

GELHAR, L. W. (1986). Stochastic subsurface hydrology from theory to applications. Water Resources Research, v. 22, p. 135S-145S.

GIAMPÁ, C. E. Q.; SOUZA, J. C. (1982). Potencial aqüífero dos basaltos da Formação Serra Geral no Estado de São Paulo. In: Congresso Brasileiro de Águas Subterrâneas, 2. Salvador, BA, ABAS, Anais. p. 3-15. 
GEF - GLOBAL ENVIRONMENT FACILITY. (2002). Environmental protection and sustainable development of the Guarani aquifer system project. Report 23490, GEF/BIRD.

HEALY, R. W.; COOK, P. G. (2002). Using groundwater level to estimate recharge. Hydrogeology Journal, v. 10, p. 91-109.

HEATH, R. C. (1983). Basic ground-water hydrology. US. Geological Survey, Water Supply Paper 2220. 84 p.

HILLEL, D. (1980) Fundamentals of soil physics, New York : Academic Press. 413 p.

IPT - INSTITUTO DE PESQUISAS TECNOLÓGICAS. (1981). Mapa Geológico do Estado de São Paulo. Escala 1:500.000. São Paulo. IPT Monografias, 6. Publicação 1 184, v.2.

- (1993). Geologia das folhas Campinas (SF.23-Y-A) e Ribeirão Preto (SF.23-V-C). São Paulo. IPT. Rel. 31723.

- (2003). Diagnóstico da situação atual dos recursos hídricos e estabelecimento de diretrizes técnicas para a elaboração do Plano da Bacia Hidrográfica do Tietê/Jacaré. IPT. Relatório 40.674. São Paulo.

IH - INSTITUTE OF HYDROLOGY. (1980). Low flow studies, Institute of Hydrology. Report 1. Wallingford, U.K.

JOHNSTON, C. D. (1987). Preferred water flow and localised recharge in a variable regolith. Journal of Hydrology. v. 94, p. 129-142.

JORGENSEN, D. G. (1989). Accounting for intracell flow in models with emphasis on water-table recharge and stream-aquifer interaction - Part 1, problems and concepts. . Water Resources Research. v. 25, p. 669-676. 
KINZELBACH W.; AESCHBACH W.; ALBERICH C.; GONI, I. B.; BEYERLE, U.; BRUNNER, P.; CHIANG, W. H.; RUEEDI, J.; ZOELLMANN, K. (2002). A survey of methods for groundwater recharge in arid and semi-arid regions. Early Warning and Assessment Report Series, UNEP/DEWA/RS.02-2. United Nations. Environment Programme, Nairobi, Kenya.

KRABBENHOFT, D. P.; ANDERSON, M. P.; BOESER, C. J. (1990). Estimating ground-water exchange with lakes. 2. Calibration of three-dimensional, solute transport model to a stable isotope plume. Water Resources Research. v. 26, p. 2455-2462.

KRISHNAMURTHI, N.; SUNADA, D. K.; LONGENBAUGH, R. A. (1977). Mathematical modeling of natural groundwater recharge. Water Resources Research. v. 13, p. 720-724.

LEDUC, C.; FAVREAU, G.; SCHROETER, P. (2001). Long-term rise in a Sahelian water table: the Continental Terminal in southwest. Journal of Hydrology, v. 243, p. 43-54.

LERNER, D. N.; ISSAR, A.S.; SIMMERS, I. (1990). Groundwater recharge. A guide to understanding and estimating natural recharges. IAH Int Contrib Hydrog, Hannover. 345 p.

LINSLEY, R. K.; FRANZINI, J. B. (1978). Engenharia de Recursos Hídricos. São Paulo: Editora McGraw-Hill do Brasil e Editora da Universidade de São Paulo. 798 p.

MARSILY, G. (1986). Quantitative Hydrogeology. Academic Press, 440 p.

MATOS, I. S. (1987). Aplicação de um modelo de balanço hídrico na Bacia do Rio Jacaré-Guaçu. 189 p. Dissertação (Mestrado) - Escola de Engenharia de São Carlos, Universidade de São Paulo, São Carlos. 1987. 
MATOS, S.L.F. de. (1995). O contato entre o Grupo Passa Dois e a Formação Pirambóia na borda leste da Bacia do Paraná no Estado de São Paulo. 110 p. Dissertação (Mestrado) - Instituto de Geociências, Universidade de São Paulo, São Paulo. 1995.

MEIER, P. M.; CARRERA, J.; SANCHEZ-VILA, X. (1998). An evaluation of Jacob's method for the interpretation of pumping tests in heterogeneous formations. Water Resources Research. v. 34, p. 1011-1025.

MELO, M. S. de. (1995). A Formação Rio Claro e depósitos associados: sedimentação neocenozóica na Depressão Periférica Paulista. 114 p. Tese (Doutorado) - Instituto de Geociências, Universidade de São Paulo, São Paulo. 1995.

MONTENEGRO, S. M. G. L.; MONTENEGRO, A. A. A.; MACKAY, R. (1999). Caracterização da variabilidade espacial de parâmetros hidráulicos em solos aluviais no Estado de Pernambuco. Revista Brasileira de Recursos Hídricos. v. 4, n. 2, p. 3-20.

MORRIS, D. A.; JOHNSON, A. I. (1967). Summary of hydrology and physical properties of rock and soil materials. US.Geological Survey, Water Supplay Paper 1839. $13 \mathrm{p}$.

NEUMAN, S. P. (1979). Perspective on "delayed yield". Water Resources Research. v. 15, p. 899-908.

NATHAN, R. J.; McMAHON, T. A. (1990). Evaluation of Automated Techniques for Base Flow and Recession Analysis. Water Resources Research. v. 26, p. 14651473.

OAS/GEF - ORGANISATION OF AMERICAN STATES I GLOBAL ENVIRONMENT FACILITY. (2001). Proyecto para la Protección Ambiental y Desarrollo Sostenible Integrado del SAG. Montevideo. 133 p. 
PENMAN, H. L. (1956). Evaporation: an introductory survey. Netherlands. Journal of Agricultural Science, Cambridge, v. 4, p. 9-29.

PERRONI, J. C. A. (2005). Avaliação do consumo de energia elétrica para produção de água subterrânea: o caso do abastecimento público da cidade de São Carlos - SP. 143 p. Dissertação (Mestrado) - Escola de Engenharia de São Carlos, Universidade de São Paulo, São Carlos. 2005.

PIUCI, J.; DINIZ, H. N. (1985). Conhecimento do Aqüífero Botucatu na Cidade de Araraquara - SP. Revista do Instituto Geológico. v. 6, p. 23-44.

PONÇANO, W.L. et al. (1982). A Formação Itaqueri e depósitos correlatos no Estado de São Paulo. In: Congresso Brasileiro de Geologia, 32. Salvador, BA, SBG, Anais, v.4, p. 1339-1350.

PORTELA FILHO, C. V.; FERREIRA, F. J. F.; ROSA FILHO, E. F.; BUNCHMANN FILHO, A. C.; ROSTIROLLA, S. P. (2002). Estudo preliminar da conexão entre os Aqüíferos Serra Geral e Guarani com base em dados aeromagnetométricos e hidroquímicos. In: XII Congresso Brasileiro de Águas Subterrâneas, Florianópolis SC. Publicação em CD-ROM.

REBOUÇAS, A. C. (1976). Recursos hídricos subterrâneos da Bacia do Paraná. 143 p. Tese (Livre Docência) - Instituto de Geociências, Universidade de São Paulo, São Paulo. 1976.

RICE, R.C.; BOWMAN, R. S.; JAYNES, D. B. (1986). Percolation of water below an irrigated field. Soil. Sci. Am. J. v. 50, p. 855-859.

RORABOUGH, M. I. (1964). Estimating changes in bank storage and groundwater contribution to streamflow. Int. Assoc. Sci. Hydrol. v. 63, p. 432-441.

ROCHA, G. (1997). O grande manancial do Cone Sul. Estudos Avançados, Universidade de São Paulo, São Paulo. v. 30, p. 191-213. 
ROSA FILHO, E. F.; HINDI, E. C.; GIUSTI, D. A.; ROSTIROLA, S. P.; FERREIRA, F. J. F.; BITTENCOURT, A. V. L. (2003) Sistema Aqüífero Guarani Considerações preliminares sobre a influência do Arco de Ponta Grossa no Fluxo das águas subterrâneas. Águas Subterrâneas, São Paulo. v. 17, p. 91-111.

SALAMA, R. B.; BATTLE, G. A.; FARRINGTON, P.; WILSON, V. (1994). Basin geomorphological controls on the mechanism of recharge and discharge and its effect on salt storage and mobilization - comparative study using geophysical surveys. Journal of Hydrology, v. 155, p. 1-26.

SANFORD, W. (2002). Recharge and groundwater models: an overview. Hydrogeology Journal. v. 10, p. 110-120.

SANT'ANNA NETO, J.L. (1995). As chuvas no Estado de São Paulo: contribuição ao estudo da variabilidade e tendência da pluviosidade na perspectiva da análise geográfica. 253 p. Tese (Doutorado) - Faculdade de Filosofia, Letras e Ciências Humanas - Seção de Geografia, Universidade de São Paulo, São Paulo. 1995.

SCANLON, B.R.; HEALY, R. W.; COOK, P. G. (2002). Choosing appropriate techniques for quantifying groundwater recharge. Hydrogeology Journal, v 10(1), p. 18-39.

SCHNEIDER, R. L. et al. (1974). Revisão estratigráfica da Bacia do Paraná. In: $28^{\circ}$ CSBG, Porto Alegre - RS. Anais, p. 229-236.

SMA - SECRETARIA DE ESTADO DO MEIO AMBIENTE. (2004). Um exemplo de solução integrada para a criação de áreas de proteção de captações destinadas ao abastecimento público com usos de modelos de sustentabilidade e sistemas avançados de suporte de tecnologia de informação. Rel. 11.04.04. São Paulo - SP.

SILVA, R. B. G. (1983). Estudo hidroquímico e istotópico das águas subterrâneas do aqüífero Botucatu no Estado de São Paulo. 110 p. Tese (Doutorado) - Instituto de Geociências, Universidade de São Paulo, São Paulo. 1983. 
SOARES, P. C. et al. (1980). Ensaio de caracterização do Cretáceo no Estado de São Paulo: Grupo Bauru. Revista Brasileira de Geociências, v.10(3), p. 177-185.

SOARES, P. G. (1975). Divisão Estratigráfica do Mesozóico no Estado de São Paulo. Rev. Bras. Geol, v. 10, p. 177-175.

STEENHUIS, T. S.; JACKSON, C. D.; KUNG, S. K. J; BRUTSAERT, W. (1985). Measurement of groundwater recharge on Eastern Long Island. Journal of Hydrology, v. 79, p. 145-169.

STOERTZ, M. W.; BRADBURY, K. R. (1989). Mapping recharge areas using a ground-water flow model - a case study. Ground Water, v. 27, p. 220-229.

SWENSON, F. A. (1968). New theory of recharge to the artesian basin of the Dakotas. Geological Society of America Bull, v.79, p. 163-182.

TEISSEDRE, J.; SANCHES, J. L.; LOPES, M. F. C. (1982). Geometria e condições de exploração do Aqüífero Botucatu no Estado de São Paulo. $2^{\circ}$ CABAS, Salvador - BA, Anais, p. 53-63.

THORNTHWAITE, C. W. (1948). An approach toward a rational classification of climate. Geographical Review, New York, v. 38, n.1, p. 55-94.

VIVES, L.; CAMPOS, H.; CANDELA, L.; GUARRACINO, L. (2001). Modelación Del Acuífero Guaraní. Boletín Geológico y Minero. v. 112, p. 51-64.

WENDLAND, E. (2003). Desenvolvimento do pacote computacional SPA (Simulação de Processos em Aqüíferos). Relatório de Pesquisa, Processo FAPESP 02/09696-3, Departamento de Hidráulica e Saneamento, Escola de Engenharia de São Carlos, Universidade de São Paulo, 78 p.

WENDLAND, E.; CUNHA, A. T. (2003). Estimativa experimental da taxa de recarga para a Zona de Afloramento do Aqüifero Guarani, na região de São Carlos - SP. Rev. Bras. Rec. Híd., v. 1, p. 1-12. 
WINTER, T. C. (2001). The concept of hydrologic landscapes. J. Am Water Resour Assoc., v. 37, p. 335-349.

ZHENG, C.; WANG, H. F.; ANDERSON, M. P.; BRADBURY, K. R. (1988). Analysis of interceptor ditches for control of groundwater pollution. Journal of Hydrology, v. 98, p. 67-81. 
APÊNDICE A - Hidrogramas 
Hidrograma de vazão total $\left(Q_{t}\right)$ com separação de vazão de base total $\left(Q_{b t}\right)$

Dados da estação fluviométrica E1 - Rio Jacaré-Guaçu

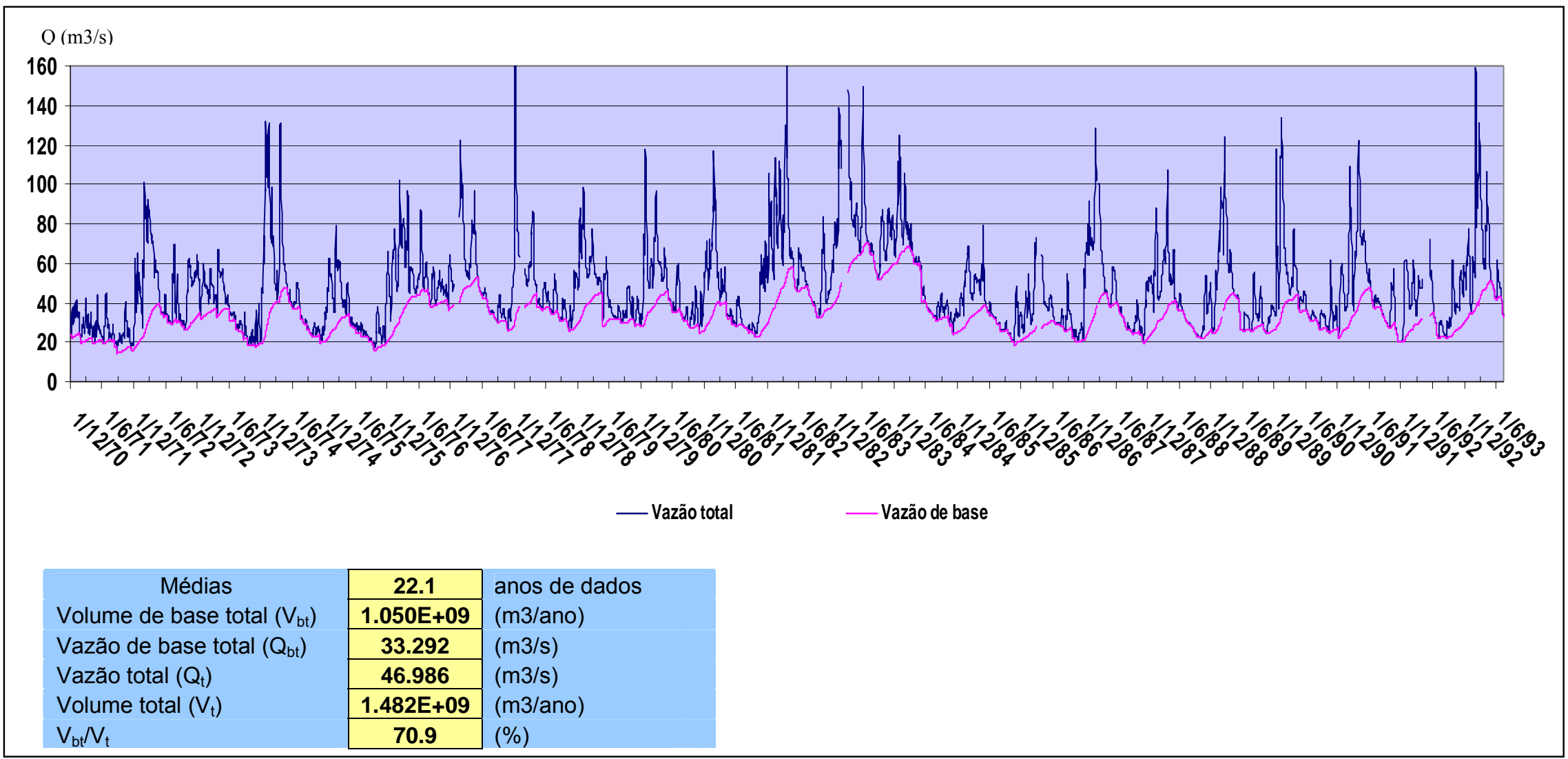

Figura 55 - Hidrograma da estação E1 - Rio Jacaré-Guaçu 
Hidrograma de vazão total $\left(Q_{t}\right)$ com separação de vazão de base total $\left(Q_{b t}\right)$

Dados da estação fluviométrica E2 - Rio Jacaré-Guaçu

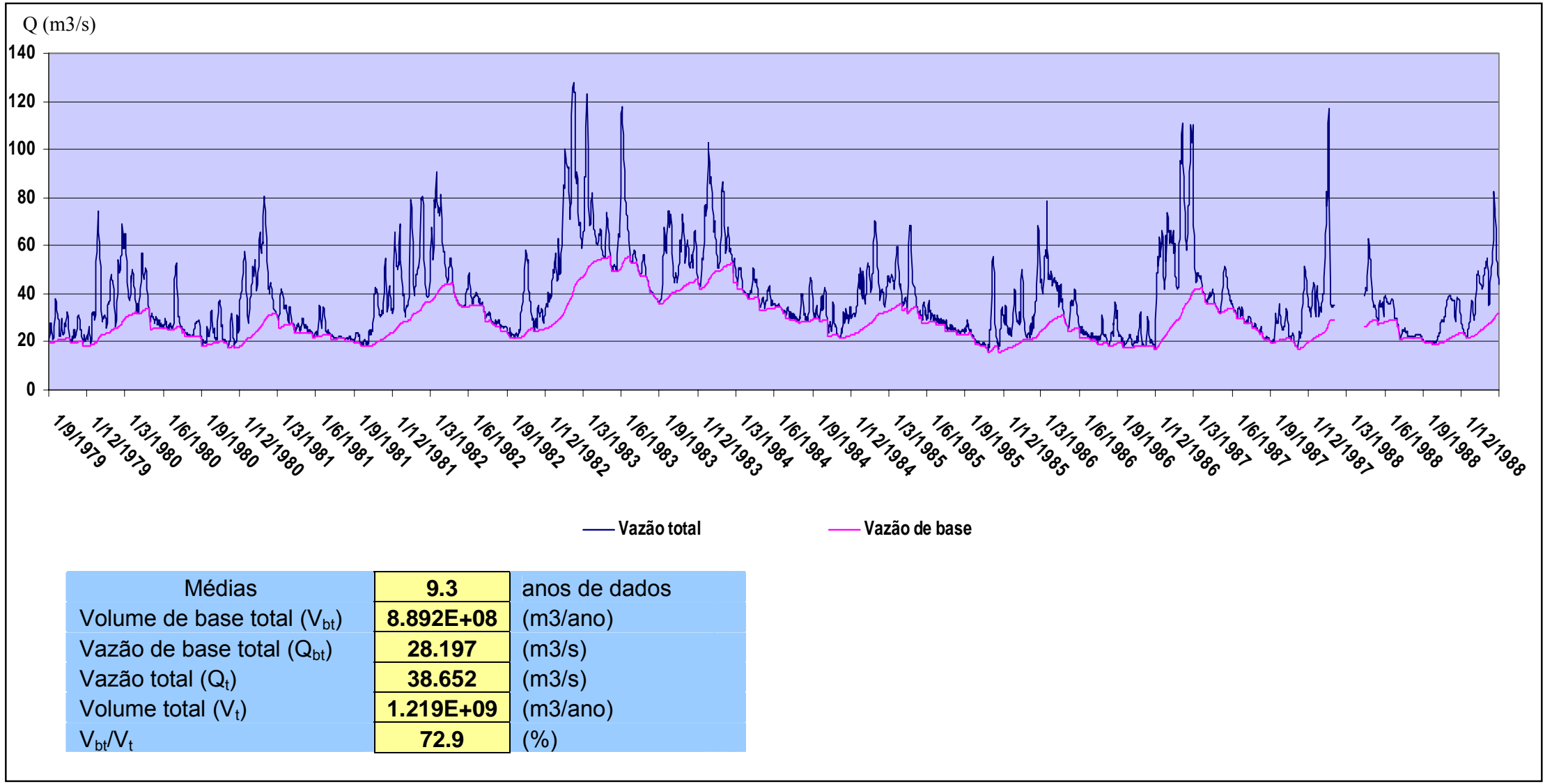

Figura 56 - Hidrograma da estação E2 - Rio Jacaré-Guaçu 
Hidrograma de vazão total $\left(Q_{t}\right)$ com separação de vazão de base total $\left(Q_{b t}\right)$

Dados da estação fluviométrica E3 - Rio Jacaré-Guaçu

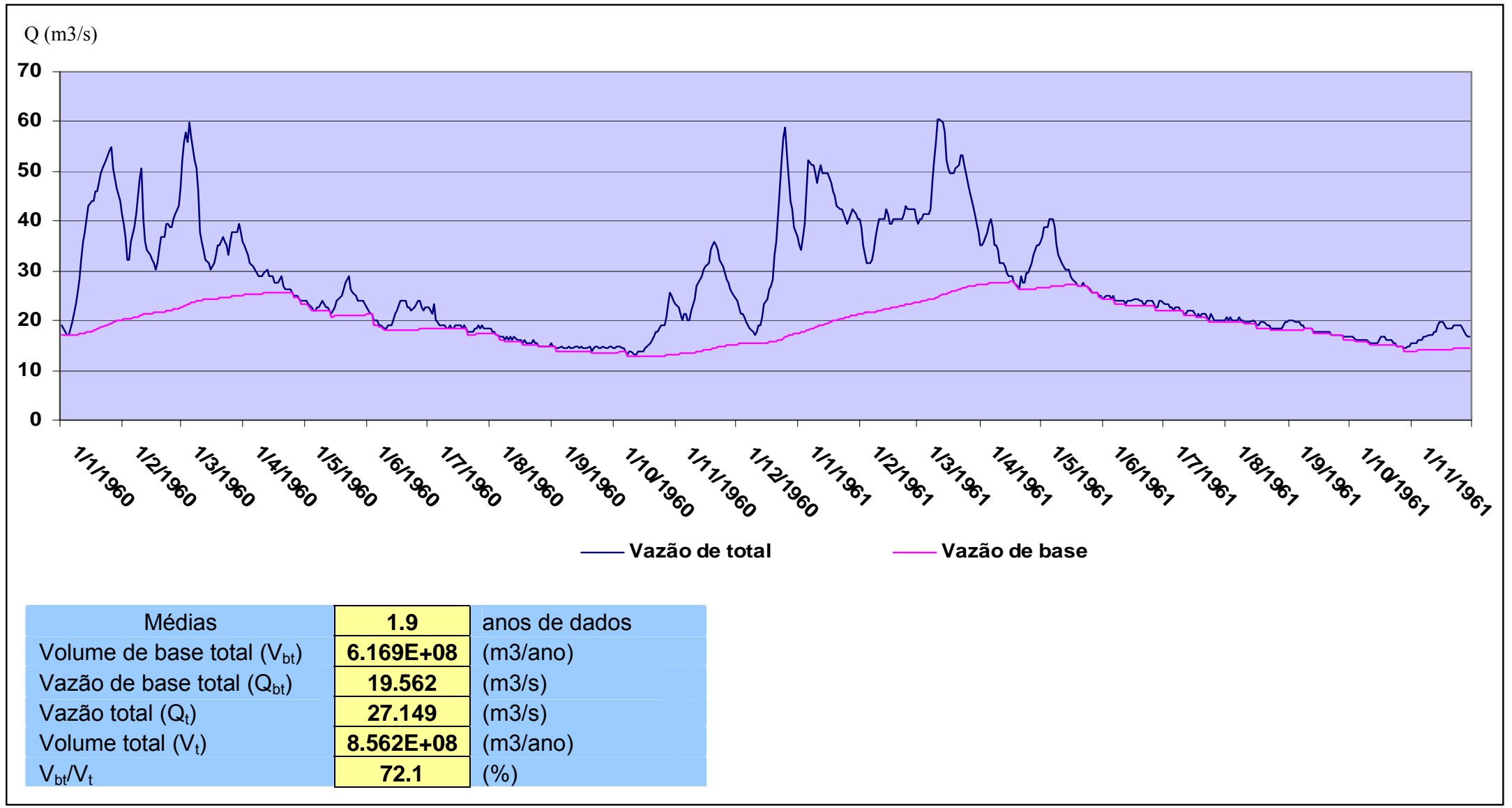

Figura 57 - Hidrograma da estação E3 - Rio Jacaré-Guaçu 
Hidrograma de vazão total $\left(Q_{t}\right)$ com separação de vazão de base total $\left(Q_{b t}\right)$

Dados da estação fluviométrica E4 - Rio Jacaré-Guaçu

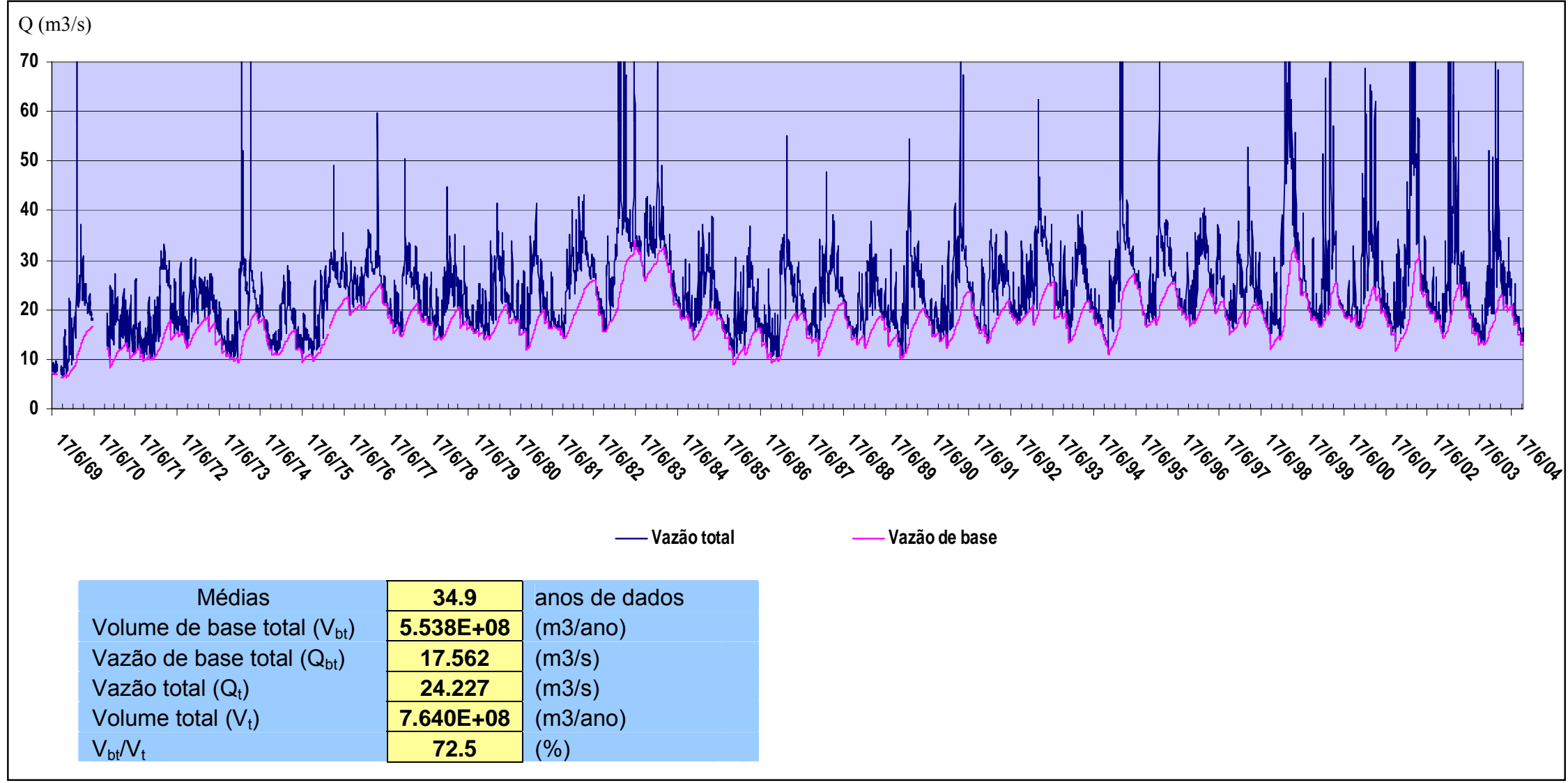

Figura 58 - Hidrograma da estação E4 - Rio Jacaré-Guaçu 
Hidrograma de vazão total $\left(Q_{t}\right)$ com separação de vazão de base total $\left(Q_{b t}\right)$

Dados da estação fluviométrica E5 - Rio Jacaré-Guaçu

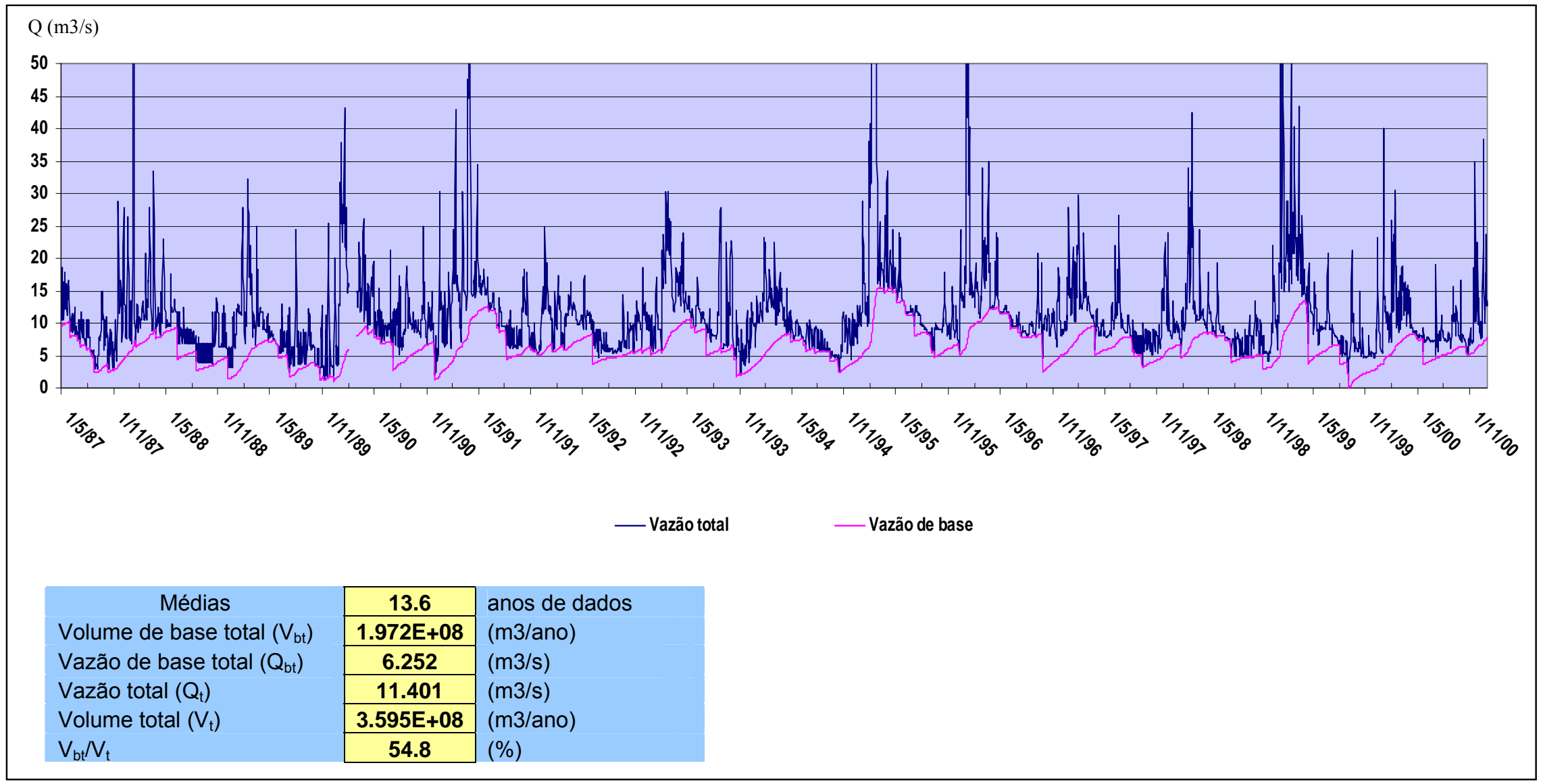

Figura 59 - Hidrograma da estação E5 - Rio Jacaré-Guaçu 
Hidrograma de vazão total $\left(Q_{t}\right)$ com separação de vazão de base total $\left(Q_{b t}\right)$

Dados da estação fluviométrica E6 - Rio Jacaré -Guaçu

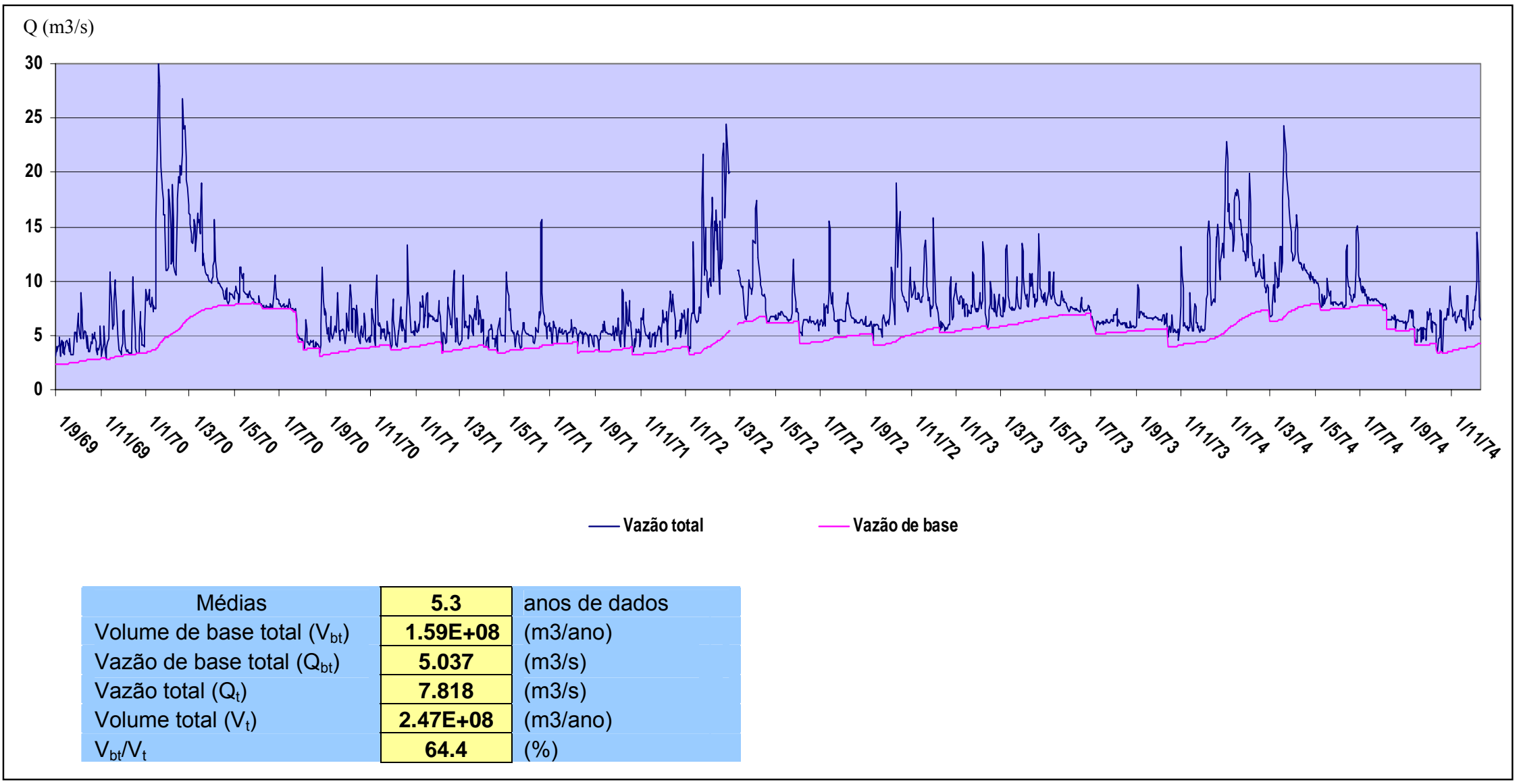

Figura 60 - Hidrograma da estação E6 - Rio Jacaré-Guaçu 
Hidrograma de vazão total $\left(Q_{t}\right)$ com separação de vazão de base total $\left(Q_{b t}\right)$

Dados da estação fluviométrica E7 - Rio Jacaré-Pepira

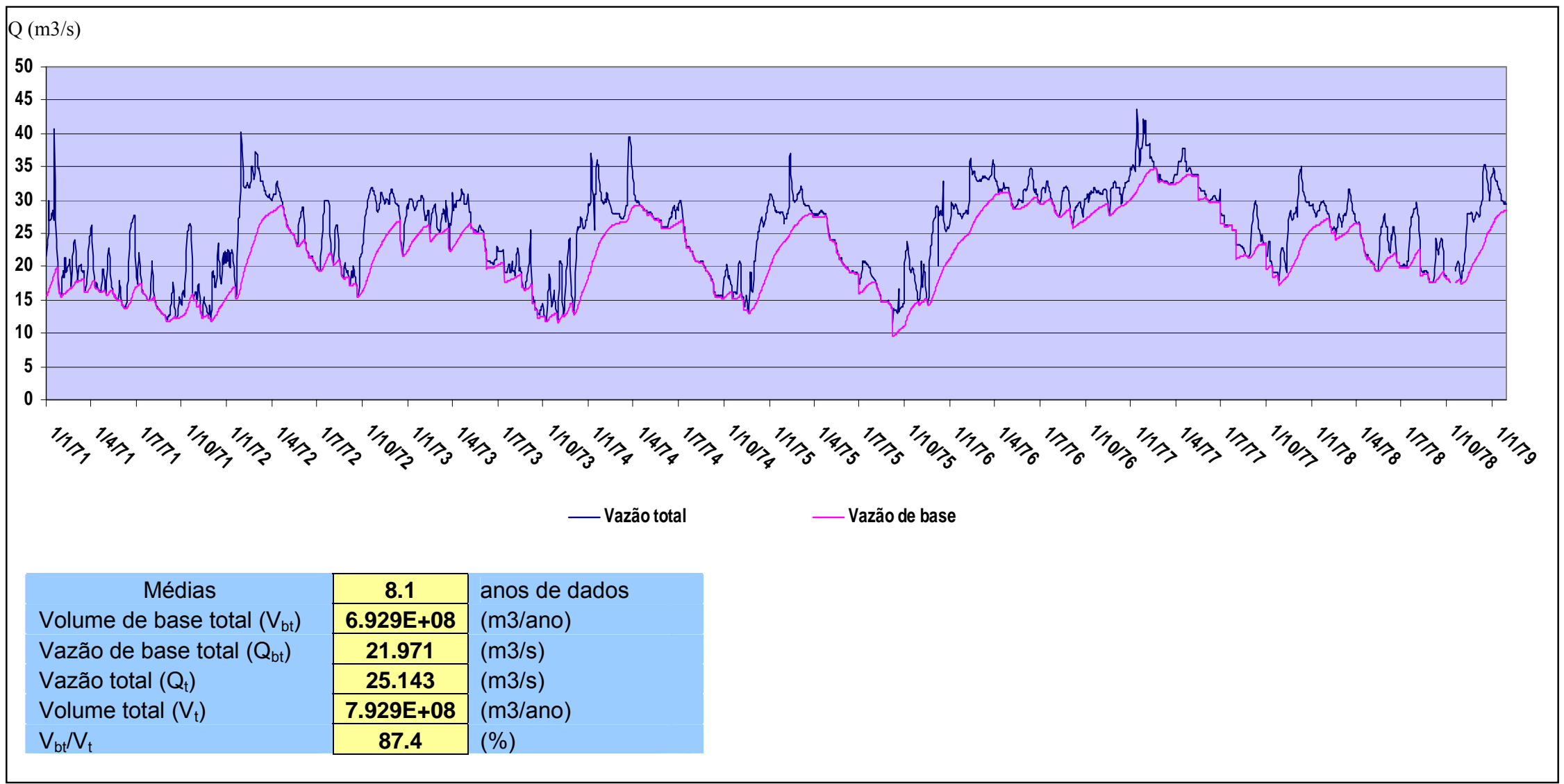

Figura 61 - Hidrograma da estação E7 - Rio Jacaré-Pepira 
Hidrograma de vazão total $\left(Q_{t}\right)$ com separação de vazão de base total $\left(Q_{b t}\right)$

Dados da estação fluviométrica E8 - Rio Jacaré-Pepira

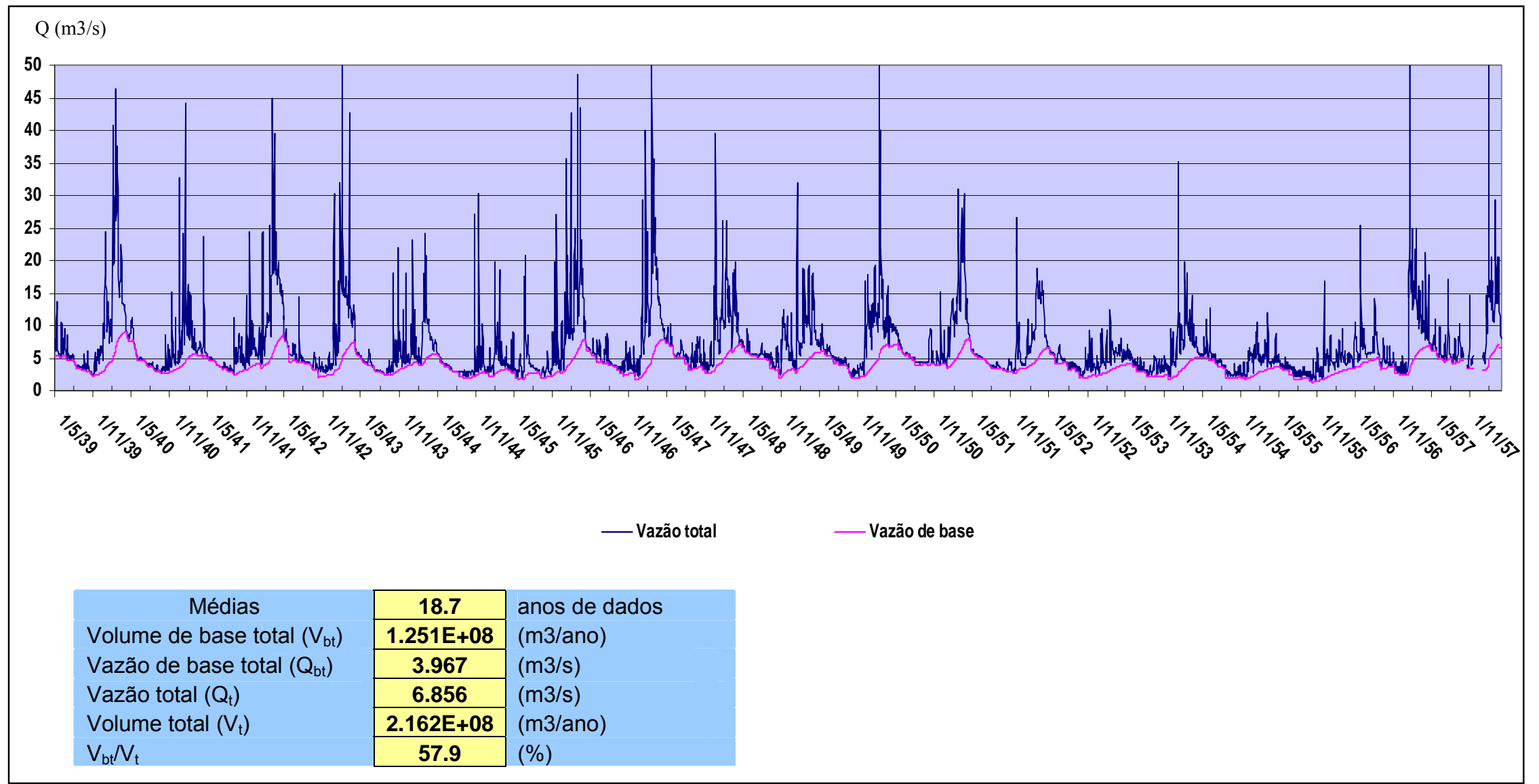

Figura 62 - Hidrograma da estação E8 - Rio Jacaré-Pepira 
Hidrograma de vazão total $\left(Q_{t}\right)$ com separação de vazão de base $\left(Q_{b}\right)$

Dados da estação fluviométrica E9 - Rio São João

Sub-bacia referência do Jacaré-Guaçu

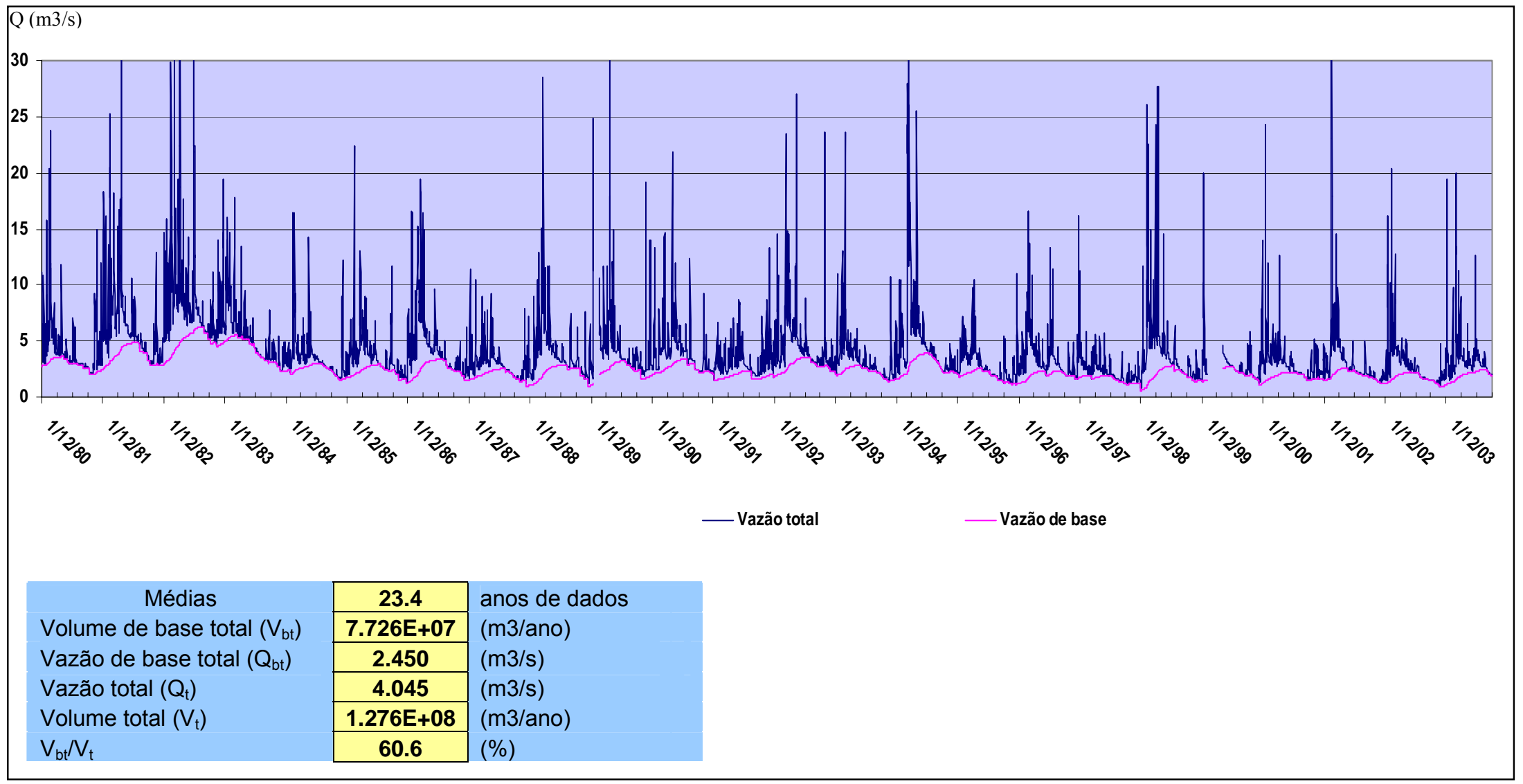

Figura 63 - Hidrograma da estação E9 - Rio São João, tributário do Jacaré-Guaçu 
Hidrograma de vazão total $\left(Q_{\mathrm{t}}\right)$ com separação de vazão de base $\left(\mathrm{Q}_{\mathrm{b}}\right)$

Dados da estação fluviométrica E10 - Ribeirão Pinheiros/Cachoeira

Sub-bacia referência do Jacaré-Pepira

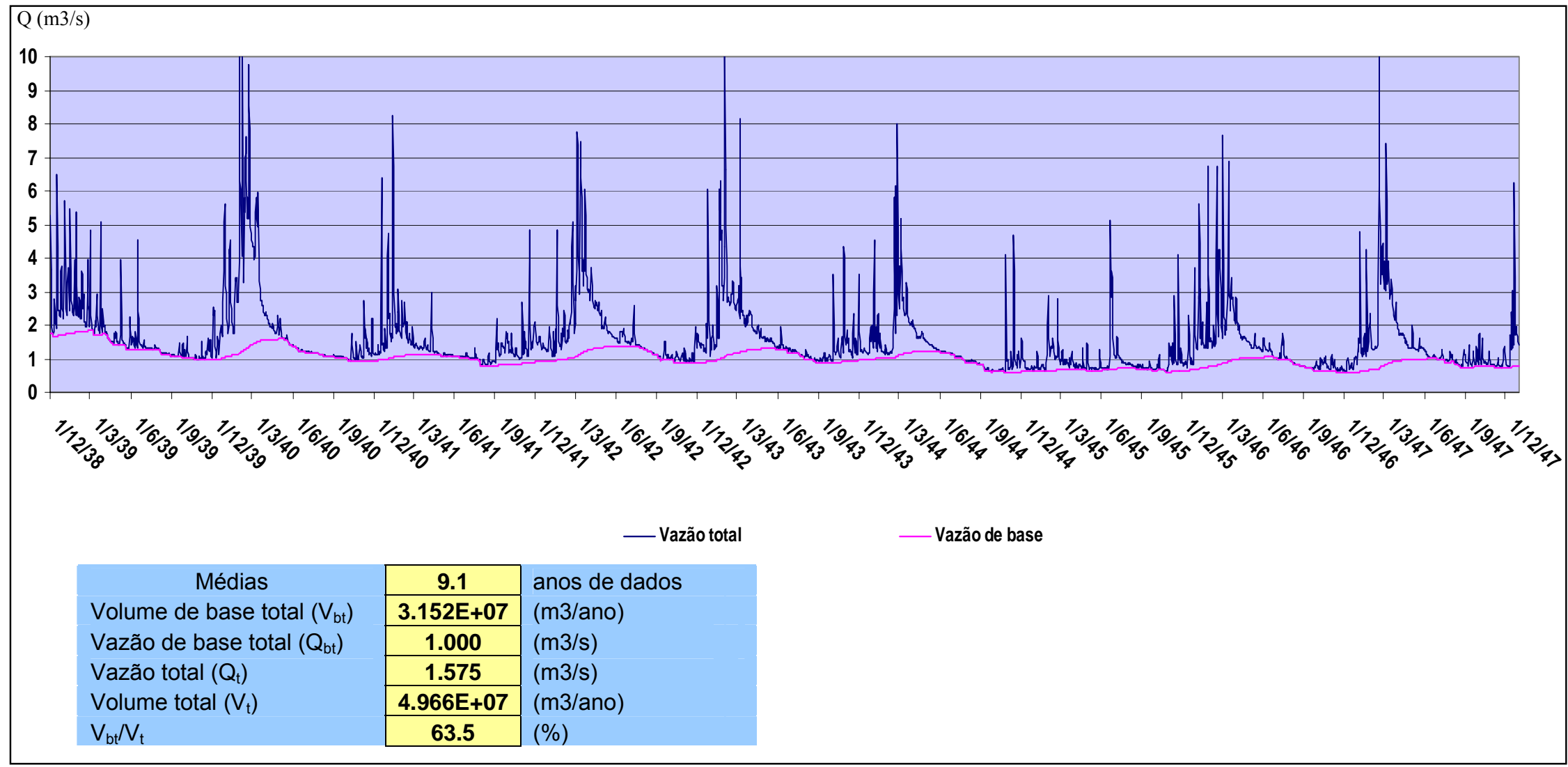

Figura 64 - Hidrograma da estação E10 - Ribeirão Pinheiros, tributário do Jacaré-Pepira 
Hidrograma de vazão total $\left(Q_{t}\right)$ com separação de vazão de base $\left(Q_{b}\right)$

Dados da estação fluviométrica E11 - Ribeirão da Onça

Sub-bacia referência do Jacaré-Guaçu

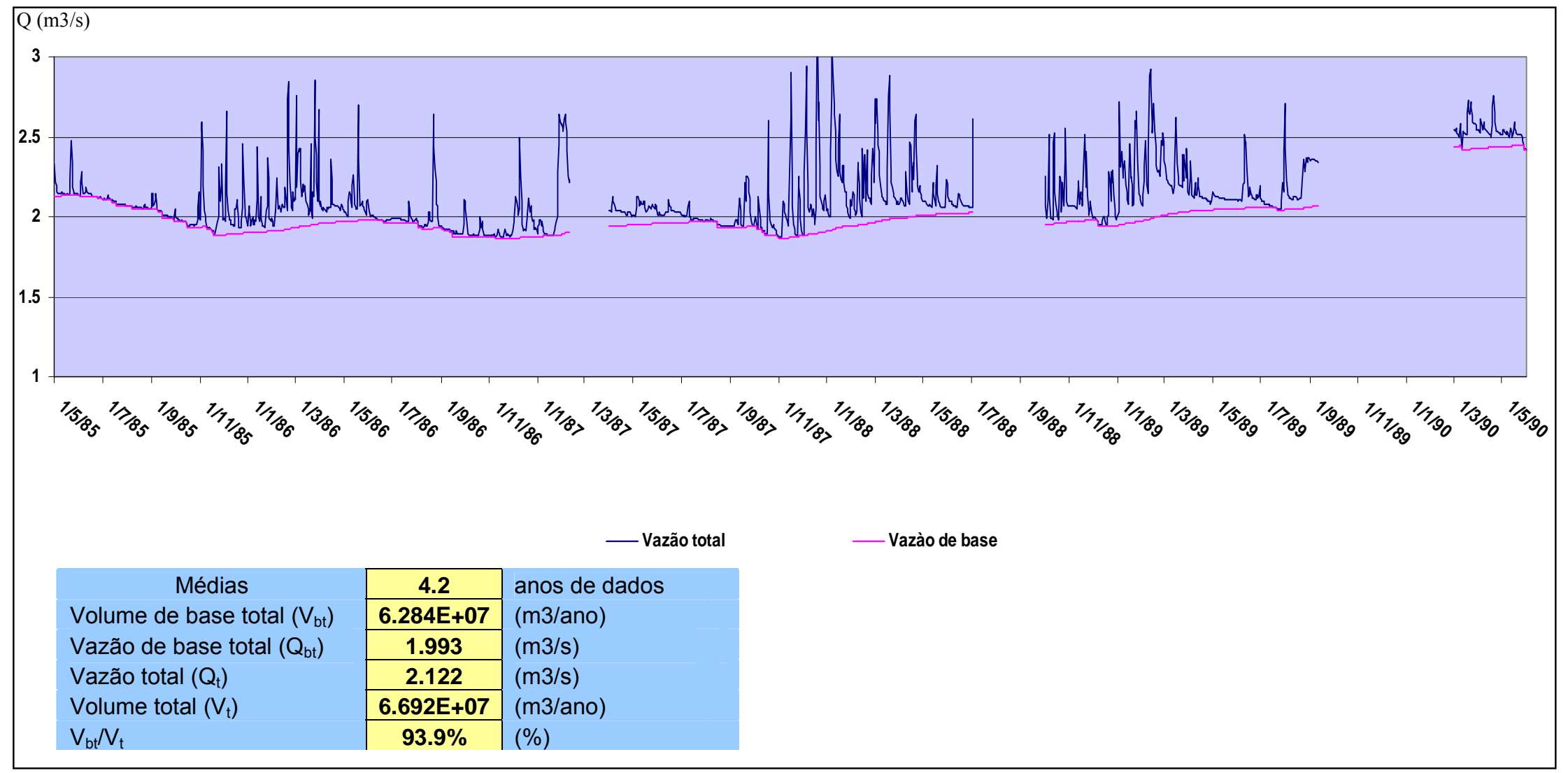

Figura 65 - Hidrograma da estação E11 - Ribeirão da Onça, tributário do Jacaré-Guaçu 
Hidrograma de vazão total $\left(Q_{t}\right)$ com separação de vazão de base $\left(Q_{b}\right)$

Dados da estação fluviométrica E12 - Córrego do Gregório

Sub-bacia referência do Jacaré-Guaçu

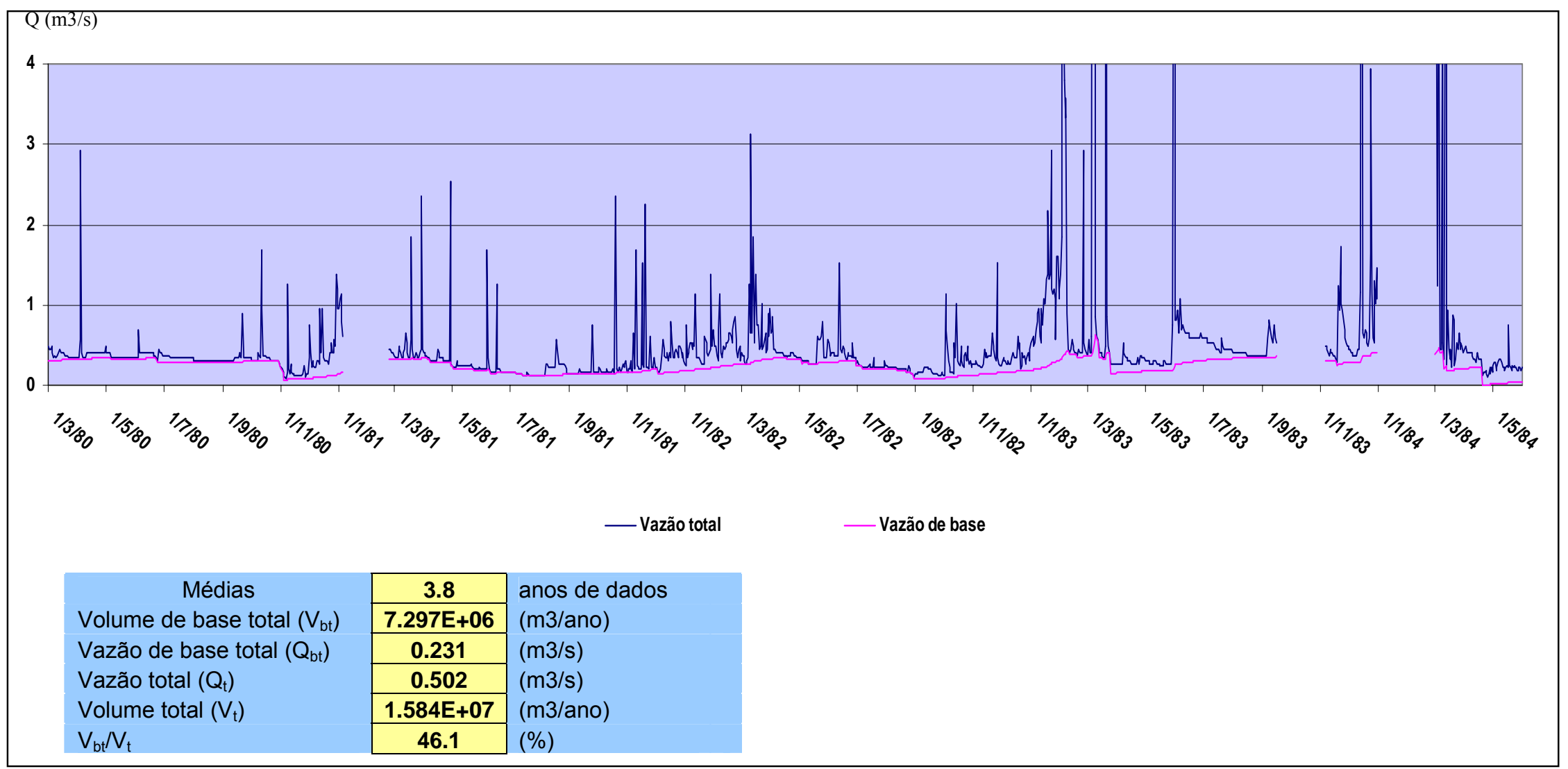

Figura 66 - Hidrograma da estação E12 - Córrego do Gregório, tributário do Jacaré-Guaçu 


\section{APÊNDICE B - Programas - Interpolacão de cargas hidráulicas e exportação de dados em formato SPA}


Instruções para instalação e utilização do aplicativo de interpolação de cargas hidráulicas e exportação de dados para arquivo ASCII, em ambiente ArcGis (compatível com versões 8x e 9x)

O aplicativo elaborado em linguagem Visual Basic é composto de dois módulos: um de interpolação dos valores de carga e outro que permite exportar os dados de um arquivo shapefile (de pontos $x, y, z$ ) para um arquivo texto, segundo formatação específica.

\section{Módulo de Interpolação}

Na tabela de atributos da layer (formato shapefile) que contém os pontos a terem suas cargas interpoladas, devem ser criados quatro campos (ou colunas) com os seguintes nomes: "Coord_X", "Coord_Y", "Trecho" e "Carga" . O uso de caixa-alta, ordem e posição em que os campos se encontram na tabela são indiferentes. Abaixo, segue a formatação e conteúdo necessários a cada campo:

1. Os campos "Coord_X" e "Coord_Y" (formato numérico inteiro) devem conter respectivamente as coordenadas (UTM) de cada ponto. Todos os pontos devem possuir coordenadas.

2. "Trecho" (formato numérico inteiro) deve conter as identificações de início de cada trecho; essa identificação deve constar apenas no primeiro ponto de cada trecho, a identificação pode ser um numero qualquer (\# 0), compatível com a característica do campo. Um trecho é definido como um conjunto de pontos que possui necessariamente cargas conhecidas nos pontos extremos, entre esses, pode possuir quaisquer outros pontos com ou sem valor de carga conhecido.

3. "Carga" (formato string) deve conter os valores de carga, atribuídos de modo crescente ou constante (do alto para baixo da tabela), representando o sentido jusante para montante das cargas nos rios. Os pontos de carga desconhecida (a interpolar) devem permanecer em branco. O caracter utilizado para separação decimal deve ser o mesmo configurado para o computador. Caso necessário, pode-se utilizar o recurso "localizer \& trocar" (em opções da tabela de atributos) para automatizar possíveis conversões de ponto para vírgula ou vice-versa. A geração dos campos deve parecer como na tabela abaixo.

No ArcMap, antes de executar o módulo, a layer contendo os dados a interpolar deve ocupar a primeira posição na área de dados (data frame).

Depois de iniciado, o módulo faz a leitura dos dados e verifica sua consistência segundo as definições acima. Assim, cada trecho é verificado quanto a possuir: 
a) existência de coordenadas em todos os pontos;

b) uma identificação (apenas no respectivo primeiro ponto, na coluna "Trecho");

c) cargas conhecidas necessariamente nos pontos extremos;

d) cargas crescentes (ou constantes), condição exigida apenas ao longo de cada trecho e não intertrechos.

Garantida a consistência dos dados, a interpolação linear (em cada trecho) é realizada entre cada par de cargas conhecidas (subtrechos). Os valores de carga (calculados e conhecidos) são dispostos no campo "Carga_Intr".

\begin{tabular}{|c|c|c|c|c|c|c|c|}
\hline \multicolumn{6}{|c|}{ 囲 Attributes of Riosjg_SPA } & $\square$ & $\mathrm{X}$ \\
\hline FID & Shape ${ }^{*}$ & Coord_X & Coord_Y & Trecho & Carga & Carga_Intr & 스 \\
\hline 497 & Point & 766087 & 7582883 & 11300 & 497 & 497 & \\
\hline 498 & Point & 765772 & 7583226 & 0 & & 500,528466 & \\
\hline 49 & Point & 765702 & 7583812 & 0 & 505 & 505 & \\
\hline 500 & Point & 766584 & 7582842 & 11400 & 497,2 & 497,2 & \\
\hline 50 & Point & 766930 & 7583043 & 0 & & 498,509888 & 0 \\
\hline 502 & Point & 767305 & 7583394 & 0 & & 500,191300 & \\
\hline 50 & Point & 767617 & 7583762 & 0 & & 501,770644 & \\
\hline 50 & Point & 767946 & 7584216 & 0 & & 503,606028 & \\
\hline 50 & Point & 768181 & 7584732 & 0 & & 505,462092 & \\
\hline 508 & Point & 768298 & 7585187 & 0 & 507 & 507 & \\
\hline 507 & Point & 768216 & 7585541 & 0 & & 515,141905 & \\
\hline 508 & Point & 767935 & 7585928 & 0 & & 525,857958 & \\
\hline 50 & Point & 767700 & 7586336 & 0 & & 536,407785 & \\
\hline 510 & Point & 767535 & 7586779 & 0 & 547 & 547 & \\
\hline 511 & Point & 768298 & 7585187 & 11401 & 507 & 507 & \\
\hline 512 & Point & 768654 & 7585390 & 0 & & 516,997546 & \\
\hline 513 & Point & 768959 & 7585836 & 0 & & 530,178821 & \\
\hline 51 & Point & 769217 & 7586431 & & 546 & 546 & $v$ \\
\hline$\leq$ & & & & & & $>$ & \\
\hline Record: $\mathbf{1 4}$ & 1 & 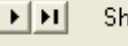 & W: All & elected & cords 1 & 1840 Select & ed.) \\
\hline
\end{tabular}

Tabela de atributos contendo valores interpolados de carga hidráulica, obtidos pelo aplicativo.

A instalação do módulo de interpolação no ambiente ArcGis é feita a partir do ArcMap seguindo os passos abaixo; os módulos devem ser instalados separadamente, um por vez:

- na barra de ferramenta Tools -> Customize...;

- na janela "Customize", abrir a paleta "Toolbars" -> New..

- em "Toolbar Name" atribuir um nome para uma nova ferramenta e em "Save in", selecionar o próprio arquivo .mxd no qual estão os dados;

- na paleta Comands, escolher a categoria UIControls -> New UIControl...;

- na janela "New UIControl “ (opção UIBittonControl) -> Create;

- em Comands, alterar o nome do botão Project. UIBittonContro11 (clik sobre ele e editar um nome qualquer desejado - Project. nome do botão; 
- $\quad$ arrastar o botão criado, de Comands para a ferramenta criada, nesta, clik-D -> Image and Text; fechar a janela "Customize";

- sobre a ferramenta criada, clik-D -> View Source ; no ambiente visual basic, inserir o código do módulo entre as duas linhas de comando: Private Sub nome do botão_Click() e End Sub. Com isso, não se deve deixar duplicado os comandos Private... (acima) nem o End Sub (abaixo).

\section{Módulo de exportação de dados}

A exportação de arquivos shapfile para arquivos de texto (ASCII), seguindo formatação específica (formato utilizado pelo simulador de processos em aqüíferos SPA), a partir do ArcMap, necessita que na tabela de atributos do respectivo arquivo shapefile (de pontos) sejam adicionados os seguintes campos: "Coord_X", "Coord_Y", "Trecho" e "Carga_Intr". As características dos campos são as mesmas, como referido no módulo de interpolação, e o campo "Carga_Intr" pode ser do tipo numérico ou string (valendo as mesmas observações em relação à colocação dos dados em campos desses tipos). Diferentemente do módulo de interpolação, agora o campo "Trecho" não possui qualquer tipo de restrição para preenchimento, podendo inclusive não possuir qualquer registro de identificação de trechos, apesar disso o campo é necessário. Alem da existência dos campos com os referidos nomes, este módulo checa apenas a condição de todos os pontos possuírem coordenadas.

O módulo permite gerar os dados também em ordem inversa a da tabela de atributos, bem como, com diferentes números de casas decimais para o valor de cargas. A formatação com que os dados são listados em arquivo texto pode ser facilmente alterada a partir do código-fonte do referido módulo. A instalação deste módulo segue os mesmos passos descritos na instalação do módulo anterior.

\section{Código Fonte}

Private Sub Interpolacao_de_Cargas_Click()

'Declaraçào de variáveis das principais classes e objetos do sistema ArcGIS ("ArcObjects")

Dim pmxdoc As IMxDocument

Set pmxdoc $=$ ThisDocument

Dim pmap As IMap

Set pmap = pmxdoc.FocusMap

Dim player As ILayer

Set player $=$ pmap $\cdot$ Layer $(0)$ 
Dim pflayer As IFeatureLayer

Set pflayer $=$ player

Dim pfclass As IFeatureClass

Set pfclass $=$ pflayer.FeatureClass

Dim pfield As IField

Set pfield $=$ New Field

Dim pfieldedit As IFieldEdit

Set pfieldedit $=$ pfield

pfieldedit.Name = "Carga_Intr"

pfieldedit.Type $=$ esriFieldTypeDouble

Dim pfields As IFields

Set pfields $=$ pfclass. Fields

'Declaração de demais variáveis do programa

Dim mensagem(6) As String

Dim i As Integer, j As Integer, jr As Integer, x As Integer, totreg As Integer

Dim poscampox As Integer

Dim poscampoy As Integer

Dim poscampotr As Integer

Dim poscampocar As Integer

Dim poscampocari As Integer

Dim $\mathrm{h}$ As Double, h1 As Double, h2 As Double

Dim nx1 As Double, ny1 As Double, nx2 As Double, ny2 As Double

Dim dist_t As Double, dist_i As Double, incpiez As Double

Dim ponteiro(1 To 5000, 1 To 5) As Double, a As Double, c As Double

mensagem(1) = "Formação incorreta de campos"

mensagem(2) = "Trecho sem identificação"

mensagem(3) = "Trecho sem definição de carga INICIAL ou com dupla

identificação"

mensagem(4) = "Trecho sem definição de carga FINAL"

mensagem(5) = "Carga posterior menor que anterior ou trecho sem identificação"

mensagem(6) = "Verificação de dados e interpolação de cargas concluídas com sucesso!"

\& vbCrLf $\&$ vbCrLf \& " $\quad$ Reabra a tabela de atributos para visualizar os dados."

'Criação de campo (nova coluna a ser preenchida com cargas interpoladas)

Dim intposfield As Integer

intposfield = pfields.FindField("Carga_Intr")

If intposfield $=-1$ Then pfclass.AddField pfieldedit

'Else

'Exit Sub

End If

'Ativacão de cursor no 10 registro da tabela de atributos (ArcMap)

Dim pfcursor As IFeatureCursor

Set pfcursor $=$ pfclass. Update $($ Nothing, False $)$ 


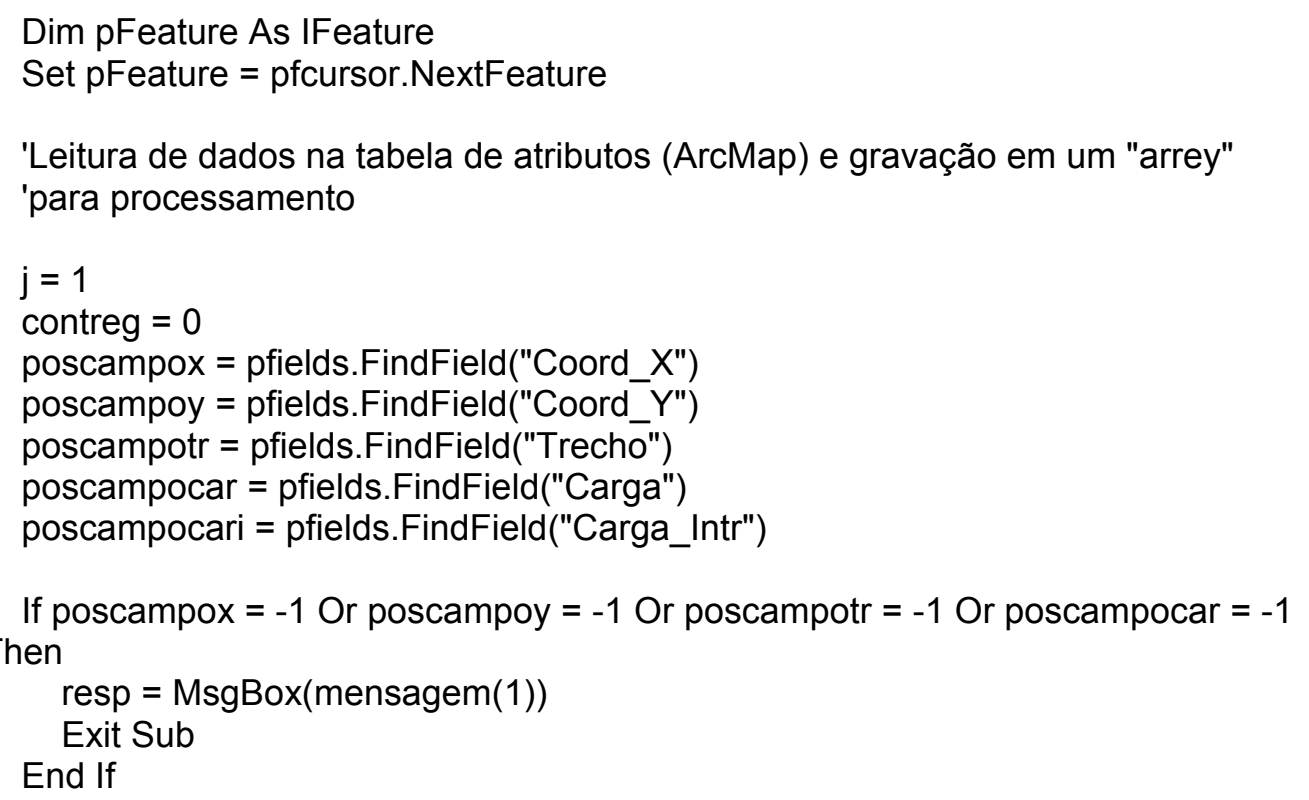

Do Until pFeature Is Nothing

ponteiro $(\mathrm{j}, 1)=p$ Feature.Value $($ poscampox $)$

ponteiro $(\mathrm{j}, 2)=p$ Feature.Value (poscampoy)

ponteiro $(j, 3)=$ pFeature.Value (poscampotr)

If Not $p F e a t u r e$. Value (poscampocar) $="$ " Then

ponteiro $(j, 4)=p F e a t u r e$. Value $($ poscampocar $)$

Else

ponteiro(j, 4) = 99999 'ou Empty

End If

ponteiro(j, 5) $=$ pFeature.Value (poscampocari)

Set $p F e a t u r e=$ pfcursor. NextFeature

$\mathrm{j}=\mathrm{j}+1$

totreg $=$ totreg +1

Loop

'Verificação de consistência de dados

If ponteiro $(1,3)=0$ Then 'Empty Then resp $=$ MsgBox $($ mensagem(2) \& " (ID: 0)")

Exit Sub

End If

If ponteiro $(1,4)=99999$ Then

resp = MsgBox(mensagem(3) \& " (ID: 0)")

Exit Sub

End If

$\mathrm{j}=2$

Do While $\mathrm{j}<=$ totreg

If ponteiro(j, 3) $>0$ Then

$\mathrm{j}=\mathrm{j}-1$

If ponteiro(j, 4) $=99999$ Then

resp = MsgBox (mensagem(4) \& " (ID: " \& j - 1 \& ")") 

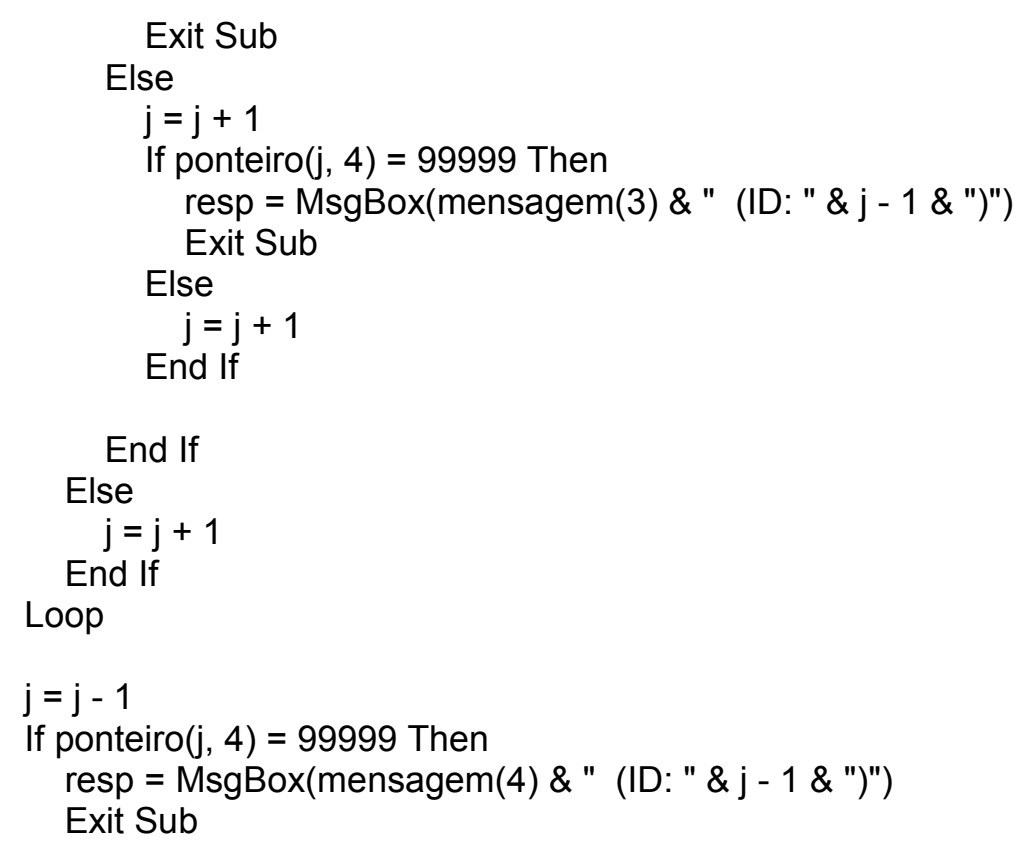

End If

$\mathrm{j}=1$

Do While ponteiro(j, 3) $>0$ And $\mathrm{j}<=$ totreg

$\mathrm{h} 1 \mathrm{=}$ ponteiro $(\mathrm{j}, 4)$

$\mathrm{j}=\mathrm{j}+1$

If ponteiro(j, 3) $>0$ Then

resp = MsgBox (mensagem(2) \& " (ID: " \& j - 1 \& ")")

Exit Sub

End If

Do While ponteiro(j, 3) $=0$ And $\mathrm{j}<=$ totreg

If ponteiro(j, 4) <> 99999 Then

$\mathrm{h} 2=$ ponteiro $(\mathrm{j}, 4)$

If h2 $<$ h1 Then

resp = MsgBox(mensagem(5) \& " (ID: " \& j - 1 \& ")")

Exit Sub

Else

$\mathrm{h} 1=\mathrm{h} 2$

End If

End If

$\mathrm{j}=\mathrm{j}+1$

Loop

Loop

'Identificação de subtrechos a interpolar (trechos contendo cargas conhecidas 'apenas nos pontos extremos)

$\mathrm{j}=1$

Do While $\mathrm{j}<=$ totreg

$\mathrm{j}=\mathrm{j}+1$

If ponteiro(j, 4) = 99999 Then $j=j-1$

Else

Do While ponteiro(j, 4) <> 99999 And j <= totreg 


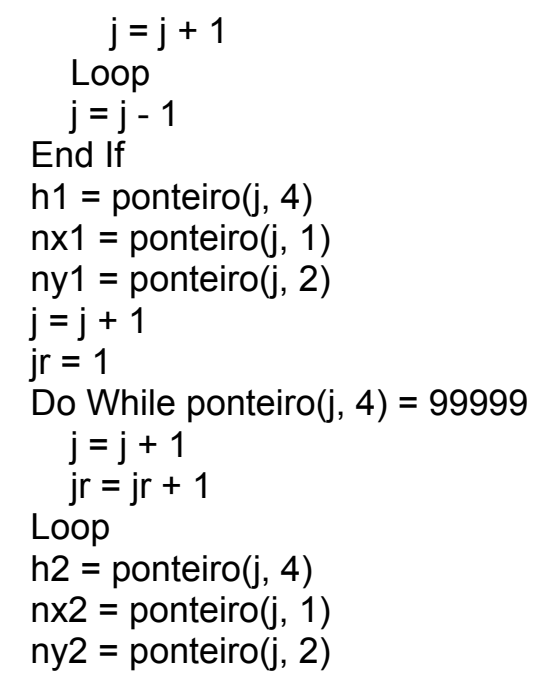

'Interpolação de cargas nos subtrechos, a partir dos valores extremos conhecidos

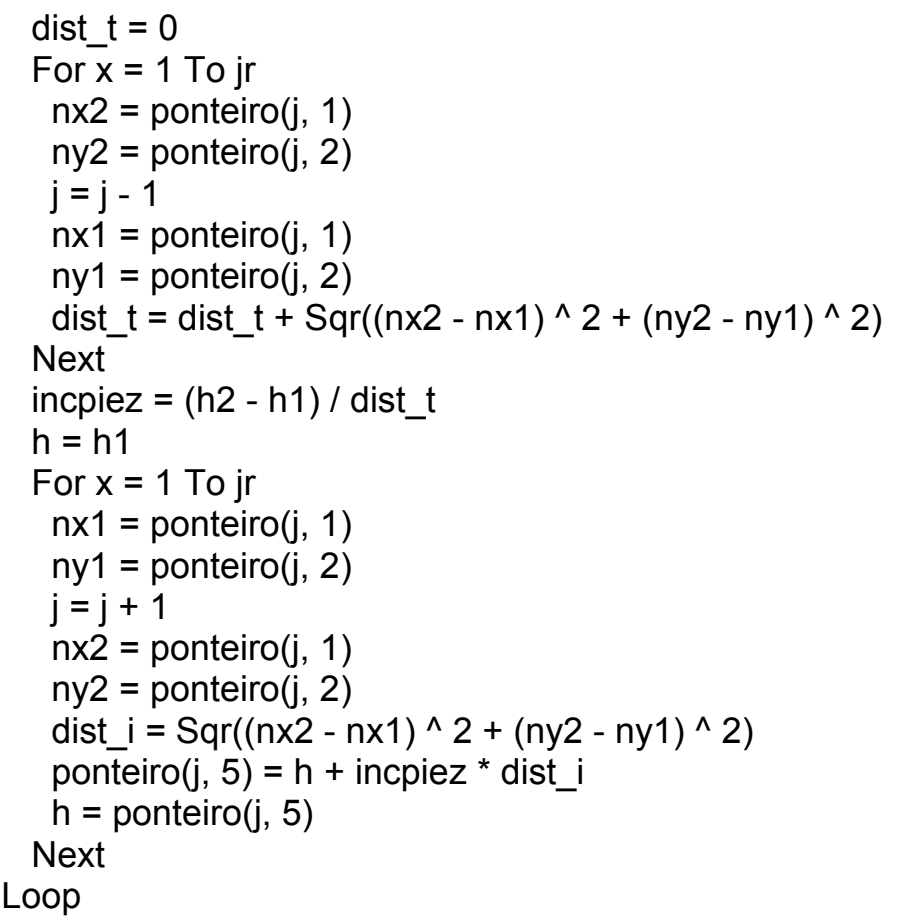

'Colocação de dados interpolados na tabela de atributos (ArcMap)

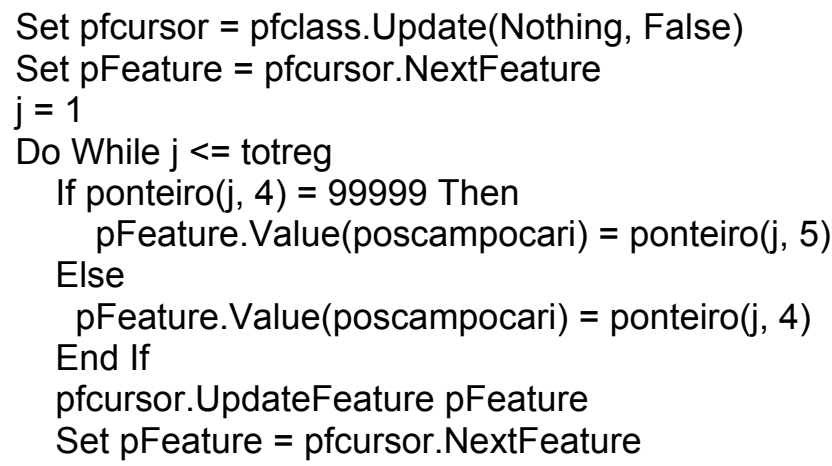




$$
\begin{aligned}
& \quad \mathrm{j}=\mathrm{j}+1 \\
& \text { Loop } \\
& \text { resp = MsgBox(mensagem(6)) } \\
& \text { End Sub }
\end{aligned}
$$

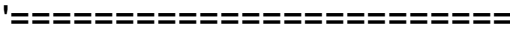

Private Sub SPA_Click()

'Declaraçào de variáveis das principais classes e objetos do sistema ArcGIS ("ArcObjects")

Dim pmxdoc As IMxDocument

Set pmxdoc $=$ ThisDocument

Dim pmap As IMap

Set pmap = pmxdoc.FocusMap

Dim player As ILayer

Set player $=$ pmap. Layer $(0)$

Dim pflayer As IFeatureLayer

Set pflayer $=$ player

Dim pfclass As IFeatureClass

Set pfclass $=$ pflayer.FeatureClass

Dim pfield As IField

Set pfield $=$ New Field

Dim pfieldedit As IFieldEdit

Set pfieldedit $=$ pfield

pfieldedit.Name = "Carga_Intr"

pfieldedit.Type $=$ esriFieldTypeDouble

Dim pfields As IFields

Set pfields $=$ pfclass. Fields

'Declaração de demais variáveis do programa

Dim mensagem(2) As String

Dim j As Integer, CasasDecimais As Integer, totreg As Integer

Dim poscampox As Integer

Dim poscampoy As Integer

Dim poscampotr As Integer

Dim poscampocari As Integer

Dim casadec As Integer

Dim Casaprod As Double, Parteint As Double, Partedec As Double, decm As

Double

Dim Decprod As Double, Decarred As Double

Dim ponteiro(1 To 5000, 1 To 5) As Double, a As Double, c As Double

pet = "c:Ispa.txt" 'Endereço onde o arquivo TXT será gerado"

mensagem(1) = "Formação incorreta de campos"

mensagem(2) = "Arquivo de texto (formato SPA) gerado com sucesso!"

\& vbCrLf \& vbCrLf \& " Endereço: " \& pet '\& CurDir("c") \& "Nome do prg" 
'Ativacão de cursor no 10 registro da tabela de atributos (ArcMap)

Dim pfcursor As IFeatureCursor

Set pfcursor $=$ pfclass. Update (Nothing, False $)$

Dim pFeature As IFeature

Set pFeature $=$ pfcursor. NextFeature

'Leitura de dados na tabela de atributos (ArcMap) e gravação em um "arrey"

'para processamento

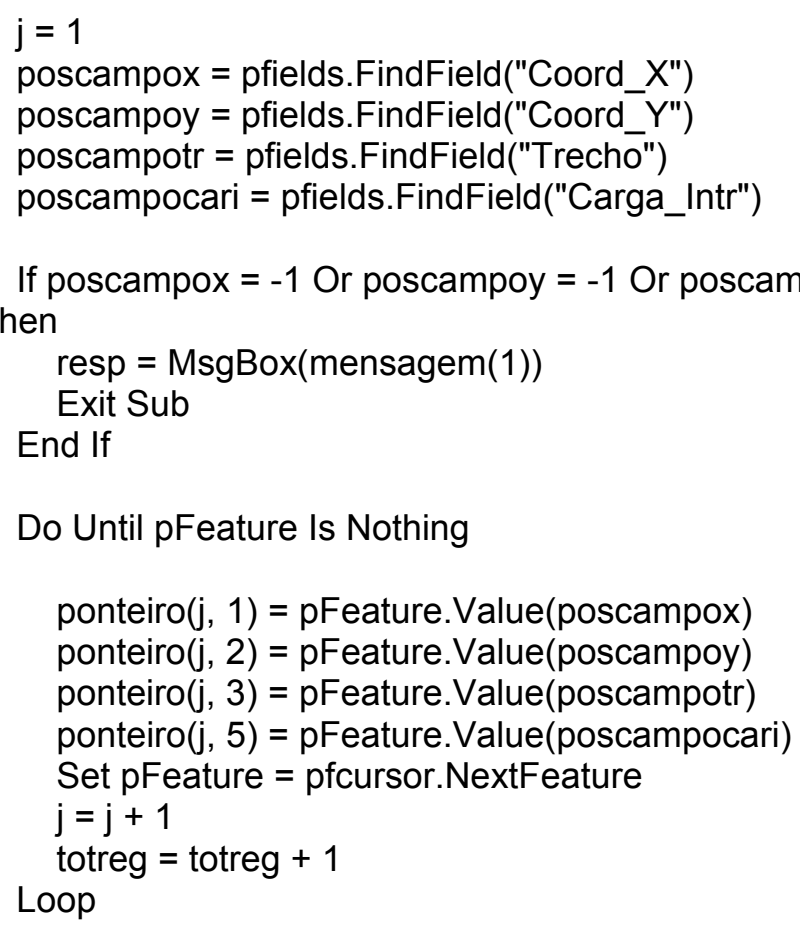

'Colocação de dados em arquivo TXT (formato SPA)

Set fs = CreateObject("Scripting.FileSystemObject")

Set $a b=$ fs.CreateTextFile(pet, True) '(CurDir("c") \& "lspa.txt", True)

'("c:larqteste.txt", True)

$\mathrm{j}=1$

CasasDecimais = 6 'Quantidade de casas decimais que se deseja expressar a Carga

Do While $\mathrm{j}<=$ totreg

If ponteiro(j, 3) $>0$ Then ab.WriteLine (Space $(0))$ ab.WriteLine (Space(6) + CStr(ponteiro(j, 3))) ab.WriteLine (Space(6) + CStr(ponteiro(j, 1)) + Space(3) + CStr(ponteiro(j, 2)) + 


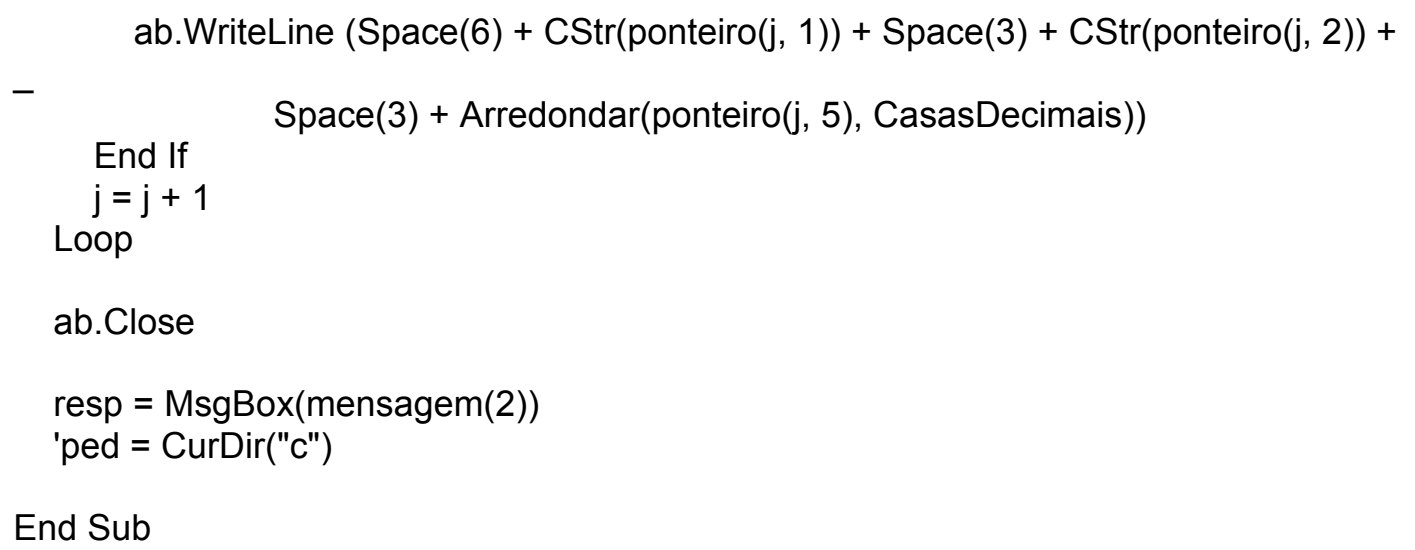

Function Arredondar(Valor As Double, Casas As Integer) As String Parteint $=$ Fix (Valor)

Partedec $=$ Valor - Parteint

Casaprod $=10^{\wedge}$ Casas

Decprod $=$ Partedec ${ }^{*}$ Casaprod

If Decprod + $0.5>$ Fix(Decprod $)+1$ Then

Decarred $=($ Fix $($ Decprod $)+1) \quad$ '/ Casaprod

Else

Decarred $=$ Fix $($ Decprod $) \quad$ '/ Casaprod

End If

If Decarred $=$ Casaprod Then

Parteint $=$ Parteint +1

Decarred $=0$

End If

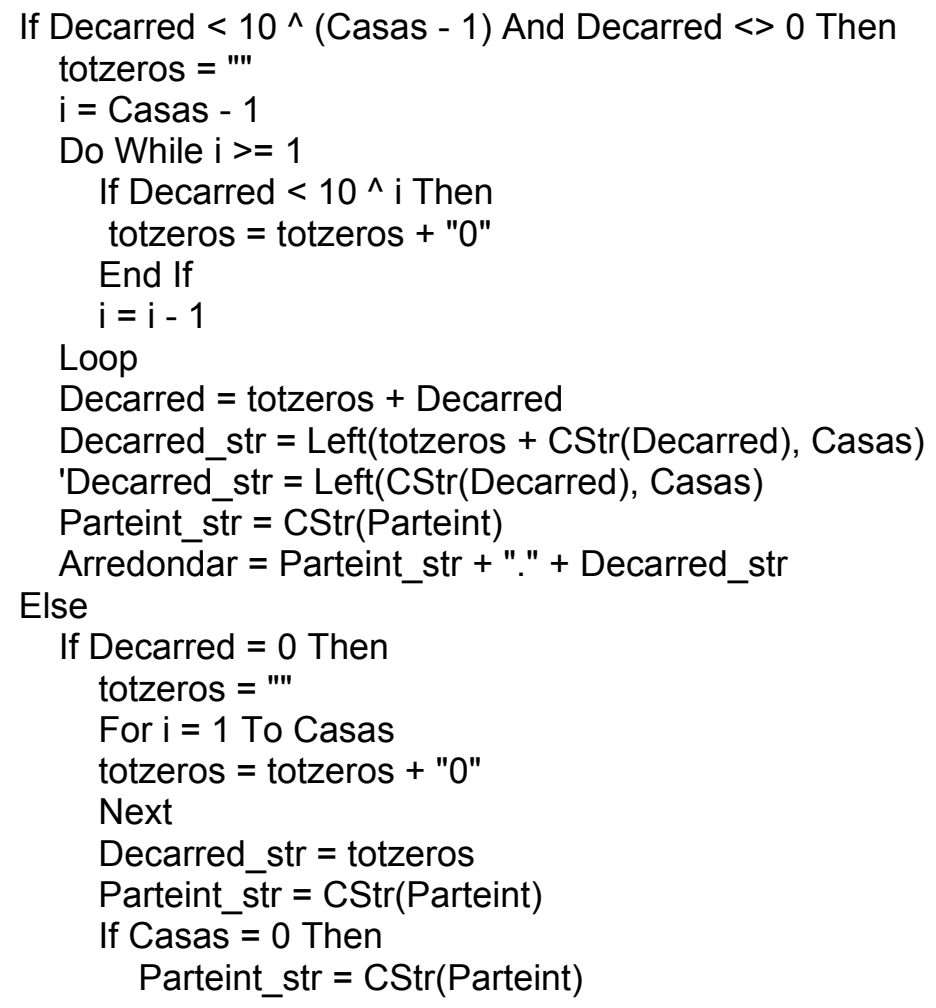




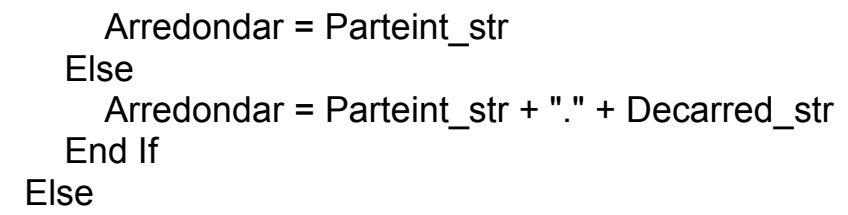

Decarred_str $=$ Left $($ CStr $($ Decarred $)$, Casas $)$

Parteint $\overline{s t r}=$ CStr(Parteint)

Arredondar = Parteint_str + "." + Decarred_str

End If

\section{End If}

\section{End Function}

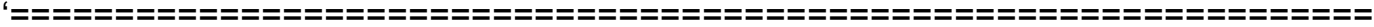




\section{ANEXO A - Poços - dados para calibração}




$\begin{array}{ccccc}\text { No. } & \text { Cidade } & \begin{array}{c}\text { UTM-E } \\ (\mathbf{k m})\end{array} & \begin{array}{c}\text { UTM-N } \\ \mathbf{( k m )}\end{array} & \begin{array}{c}\text { NE } \\ \text { (m.s.n.m) }\end{array} \\ 1 & \text { Matão } & 772300 & 7609400 & 513 \\ 2 & \text { Matão } & 771780 & 7608640 & 543 \\ 3 & \text { Matão } & 773100 & 7608200 & 551 \\ 4 & \text { Matão } & 774400 & 7607550 & 513 \\ 5 & \text { Matão } & 775800 & 7605900 & 524 \\ 6 & \text { Matão } & 753100 & 7608800 & 435 \\ 7 & \text { Pederneiras } & 729750 & 7527750 & 494 \\ 8 & \text { Pederneiras } & 728950 & 7527150 & 442 \\ 9 & \text { Pederneiras } & 728950 & 7526950 & 450 \\ 10 & \text { Pederneiras } & 727650 & 7527150 & 474 \\ 11 & \text { Pederneiras } & 728950 & 7525950 & 448 \\ 12 & \text { Pederneiras } & 729700 & 7525150 & 499 \\ 13 & \text { Jaú } & 752150 & 7534350 & 480 \\ 14 & \text { Jaú } & 750950 & 7531350 & 493 \\ 15 & \text { Ibitinga } & 724100 & 7595119 & 424 \\ 16 & \text { Ibitinga } & 722100 & 7586200 & 400 \\ 17 & \text { Ibitinga } & 723850 & 7592350 & 423 \\ 18 & \text { Ibitinga } & 705166 & 7594381 & 424 \\ 19 & \text { Ibitinga } & 724990 & 7594000 & 425 \\ 20 & \text { Ibitinga } & 723770 & 7592010 & 420 \\ 21 & \text { Ibitinga } & 723297 & 7593708 & 426 \\ 22 & \text { Ibitinga } & 725000 & 7594200 & 422 \\ 23 & \text { Itápolis } & 724747 & 7606924 & 430 \\ 24 & \text { Itápolis } & 724672 & 7606773 & 414 \\ 25 & \text { Itápolis } & 724651 & 7606745 & 402 \\ 26 & \text { Itápolis } & 727593 & 7610712 & 460 \\ 27 & \text { Borborema } & 697810 & 7608250 & 427 \\ 28 & \text { São Pedro } & 817093 & 7501172 & 517 \\ 29 & \text { São Pedro } & 818885 & 7504830 & 546 \\ 30 & \text { Analândia } & 836964 & 7546946 & 780 \\ 31 & \text { Itirapina } & 834311 & 7538322 & 794 \\ 32 & \text { Itirapina } & 829730 & 7530470 & 689 \\ & & & & \end{array}$

Estratigrafia
bau12;sg247;bt359;pi
sg247;bt
sg360;bt
bau68;sg438;bt570;pi
bau100;sg420;bt520;pi
sg120;bt
bt
sg121;bt275,pi
bt
bt
bt
bt
sg302;bt420,pi
sg325;bt450,pi
sg290;bt430;sil
sg193;bt
sg255;bt/pi
ad32;sg481;bt
sg290;bt430;sil
sg255;bt/pi
ad34;sg381bt/pi
sg290;bt432;sil
sg223;bt
sg275;bt
sg244;bt
bau54;sg320;bt/pi
sg352;bt
bt133;irat;tuba;sill
pi
solo20;sil50;pi
solo12;btl64;pi
bt24;sil153;bt/pi

$\begin{array}{cccc}\text { Profund. } & \text { Cota } & \mathbf{Q}(\mathbf{m} \mathbf{3} / \mathbf{h}) & \begin{array}{c}\text { Data } \\ \text { Const/T.bomb }\end{array} \\ 442 & 540 & 243.7 & 1985 \\ 300 & 580 & 80 & 1973 \\ 375 & 570 & 720 & 1961 \\ 580 & 600 & - & - \\ 622 & 650 & 126.43 & 1986 \\ 300 & 460 & - & - \\ 255 & 520 & 25 & 1975 \\ 319 & 480 & 100 & 1996 \\ 155 & 480 & 50 & 1969 \\ 214 & 555 & 25 & 1975 \\ 93 & 450 & 72 & 1956 \\ 162 & 501 & 20 & 1969 \\ 552 & 535 & 141.4 & 1985 \\ 530 & 561 & 135 & 1985 \\ 433 & 460 & - & - \\ 195 & 440 & 8 & 1998 \\ 417 & 500 & 198 & - \\ 482 & 450 & 28 & 1999 \\ 434 & 460 & 230 & 1978 \\ 417 & 475 & 200 & 1986 \\ 464 & 512 & 95.3 & 1995 \\ 434 & 460 & 100 & 1978 \\ 323 & 452 & 90 & 1986 \\ 292 & 466 & 90 & 1984 \\ 262 & 453 & 48 & 1982 \\ 539 & 552 & - & - \\ 452 & 452 & 60 & 1996 \\ 448 & 522 & - & - \\ 150 & 575 & - & - \\ 86 & 835 & - & - \\ 185 & 819 & 55 & 2003 \\ 120 & 730 & - & - \\ & & & \end{array}$




\begin{tabular}{|c|c|c|c|c|c|c|c|c|c|}
\hline No. & Cidade & $\begin{array}{l}\text { UTM-E } \\
(\mathrm{km})\end{array}$ & $\begin{array}{l}\text { UTM-N } \\
(\mathrm{km})\end{array}$ & $\begin{array}{c}\mathrm{NE} \\
\text { (m.s.n.m) }\end{array}$ & Estratigrafia & Profund. & Cota & $\mathrm{Q}(\mathrm{m} 3 / \mathrm{h})$ & $\begin{array}{c}\text { Data } \\
\text { Const/T.bomb }\end{array}$ \\
\hline 33 & Itirapina & 828654 & 7534387 & 753 & bt20;pi88;sil & 94 & 780 & 25.5 & 1998 \\
\hline 34 & Itirapina & 828428 & 7534515 & 755 & bt18;sil32;pi & 93 & 780 & 25.5 & 1998 \\
\hline 35 & Itirapina & 827703 & 7535165 & 735 & bt & 87 & 765 & 8.4 & 1969 \\
\hline 36 & Itirapina & 838342 & 7537096 & 720 & solo6;bt/pi & 153 & 860 & 34 & 1998 \\
\hline 37 & Itirapina & 828269 & 7535701 & 760 & $\mathrm{bt} / \mathrm{pi}$ & 110 & 770 & 80 & 1984 \\
\hline 38 & Itirapina & 828980 & 7530760 & 690 & bt24;sil53;bt & 120 & 730 & 25 & 1985 \\
\hline 39 & Itirapina & 821458 & 7543663 & 697 & pi82;sil146;pi175sil & 176 & 730 & 50 & 1987 \\
\hline 40 & Itirapina & 821453 & 7543696 & 697 & bt76;sg148;pi174;sil & 185 & 730 & 100 & 1995 \\
\hline 41 & Itirapina & 828952 & 7536367 & 767 & bt/pi80;sil94;bt & 191 & 780 & 120 & 1992 \\
\hline 42 & Itirapina & 828258 & 7535719 & 764 & sol6;bt/pi155 & 155 & 770 & 144 & 1999 \\
\hline 43 & Itirapina & 817781 & 7526051 & 721 & ita44;sg94;bt/pi & 283 & 910 & 11 & 1999 \\
\hline 44 & Itaju & 728700 & 7565800 & 452 & ad42;sg296;intrep324;sg340;bt434;pi & 480 & 502 & 450 & 1997 \\
\hline 45 & Araraquara & 790010 & 7587550 & 519 & sol18;sg138;bt144;sil148;bt/pi386;sil & 390 & 610 & 230 & 2001;tb2004 \\
\hline 46 & Araraquara & 784630 & 7584260 & 473 & bt101;sil & 103 & 495 & 6.3 & 2000 \\
\hline 47 & Araraquara & 784610 & 7583620 & 488 & bt & 72 & 510 & 6 & 1999 \\
\hline 48 & Araraquara & 797800 & 7583150 & 655 & $\begin{array}{c}\text { ad23;sg34;bt192; } \\
\text { sil282;pi360;sil }\end{array}$ & 362 & 720 & 193 & 1998 \\
\hline 49 & Araraquara & 794400 & 7587080 & 567 & sg115;bt & 300 & 645 & 72 & 1973 \\
\hline 50 & Araraquara & 792160 & 7587660 & 502 & ad22;sg163;bt/pi & 306 & 660 & 20 & 2002 \\
\hline 51 & Araraquara & 789310 & 7585210 & 508 & bau36;sg142;bt232;pi & 274 & 630 & 30 & 2002 \\
\hline 52 & Araraquara & 787500 & 7588000 & 498 & $\begin{array}{c}\text { sol22;sg154;sil166; } \\
\text { sg236;bt/pi }\end{array}$ & 366 & 635 & 150 & 1999 \\
\hline 53 & Araraquara & 787290 & 7587750 & 509 & ad29;sg198;bt & 360 & 630 & 150 & 1990 \\
\hline 54 & Araraquara & 792400 & 7584200 & 497 & ad10;sg192;bt/pi406 & 406 & 650 & 224 & 1995 \\
\hline 55 & Araraquara & 788690 & 7585870 & 528 & bt27;sg85;bt & 130 & 618 & 12 & 1997 \\
\hline 56 & Araraquara & 797300 & 7586250 & 618 & $\mathrm{bt} / \mathrm{pi} 252 ; \mathrm{sg}$ & 256 & 650 & 180 & $1982 \mathrm{c} / \mathrm{tb}$ \\
\hline 57 & Araraquara & 792780 & 7595400 & 503 & $\begin{array}{l}\text { solr,adp4;,sg240; } \\
\text { bt/pi446;sil }\end{array}$ & 453 & 660 & 250 & 1999 \\
\hline 58 & Araraquara & 749700 & 7593950 & 519 & ad28;sg157;gua & 405 & 660 & 220 & 1992c/tb \\
\hline 59 & Araraquara & 782150 & 7590200 & 550 & ad60;sg140;gua & 160 & 660 & 10 & 1974;tb2001 \\
\hline
\end{tabular}




\begin{tabular}{|c|c|c|c|c|c|c|c|c|c|}
\hline No. & Cidade & $\begin{array}{l}\text { UTM-E } \\
(\mathbf{k m})\end{array}$ & $\begin{array}{c}\text { UTM-N } \\
\text { (km) }\end{array}$ & $\begin{array}{c}\text { NE } \\
\text { (m.s.n.m) }\end{array}$ & Estratigrafia & Profund. & Cota & $\mathrm{Q}(\mathrm{m} 3 / \mathrm{h})$ & $\begin{array}{c}\text { Data } \\
\text { Const/T.bomb }\end{array}$ \\
\hline 60 & Araraquara & 800473 & 7587433 & 600 & gua & 217 & 720 & - & $2004 \mathrm{med}$ \\
\hline 61 & Araraquara & 782850 & 7589650 & 556 & bau60;sil84;intrt94;sc131;bt & 180 & 660 & 10 & 1973 \\
\hline 62 & Araraquara & 796334 & 7582862 & 641 & bau82;bt242;sil250;pi & 333 & 710 & - & - \\
\hline 63 & Araraquara & 794713 & 7588433 & 525 & bau26;sg150;bt/pi & 413 & 665 & - & - \\
\hline 64 & Matão & 749210 & 7615350 & 476 & ad43;sg167;bt/pi387;sil389 & 389 & 540 & 400 & 2004 \\
\hline 65 & Matão & 756193 & 7614990 & 469 & al10;sg228;bt & 230 & 502 & 45 & 1999;tb2002 \\
\hline 66 & Matão & 756100 & 7614777 & 471 & al10;sg229;bt & 229 & 505 & 45 & 1999;tb2003 \\
\hline 67 & Matão & 772100 & 7609200 & 505 & ad10;sg222;bt & 302 & 550 & 60 & 1973 \\
\hline 68 & Matão & 773650 & 7610450 & 495 & sg359;bt/pi & 540 & 600 & 197 & 1998 \\
\hline 69 & Matão & 765000 & 7610800 & 468 & sol20;sg202;bt & 352 & 500 & 68 & 1992;tb1998 \\
\hline 70 & Matão & 774200 & 7604200 & 535 & bau36;sg320;bt & 603 & 620 & 50 & 2001 \\
\hline 71 & Matão & 761953 & 7598397 & 524 & bau97;sg282;bt/pi & 362 & 610 & 185 & 2003 \\
\hline 72 & Matão & 761828 & 7594742 & 531 & ad30;sg150;bt & 250 & 605 & 90 & 2000 \\
\hline 73 & Gav Peixoto & 769090 & 7592570 & 561 & ad57;sg97;bt & 273 & 617 & 80 & 2002 \\
\hline 74 & Gav Peixoto & 767000 & 7589800 & 556 & ad7;sg167;bt & 320 & 610 & 40 & 2001 \\
\hline 75 & Gav Peixoto & 763330 & 7593490 & 514 & sg106;gua & 114 & 550 & 11 & 1999 \\
\hline 76 & Gav Peixoto & 756849 & 7582575 & 453 & sg182;bt/pi & 322 & 514 & - & - \\
\hline 77 & Gav Peixoto & 751679 & 7582658 & 445 & bau20,sg48;bt126;pi & 212 & 510 & - & - \\
\hline 78 & Brotas & 801550 & 7528060 & 610 & sg16;bt90;pi150;sil & 156 & 756 & 22.3 & 2002 \\
\hline 79 & Brotas & 818125 & 7546816 & 685 & bt & 50 & 690 & 3 & 1995 \\
\hline 80 & Brotas & 817482 & 7544229 & 715 & $\mathrm{bt} / \mathrm{pi}$ & 103 & 730 & 13 & 1996 \\
\hline 81 & Brotas & 811094 & 7535423 & 730 & bt34;pi & 160 & 750 & - & - \\
\hline 82 & Bocaina & 746720 & 7553340 & 475 & sol;10bt & 142 & 514 & 35 & 1999 \\
\hline 83 & Bocaina & 749850 & 7546500 & 535 & bt & 120 & 580 & 9 & 2001 \\
\hline 84 & Bocaina & 759790 & 7553310 & 454 & sg122;bt222;pi & 320 & 500 & 150 & 1999 \\
\hline 85 & Bocaina & 760860 & 7552360 & 466 & sg171;bt/pi & 174 & 555 & 5 & 2003 \\
\hline 86 & Bocaina & 756150 & 7550300 & 487 & sg80;bt/pi309;per & 312 & 560 & 70 & 1980 \\
\hline 87 & Bocaina & 755750 & 7550200 & 487 & sg107;bt & 110 & 575 & 13 & 1970 \\
\hline 88 & Bocaina & 754590 & 7549375 & 487 & sg80;bt & 309 & 560 & - & - \\
\hline 89 & Boa Esp Sul & 754720 & 7569690 & 482 & bt/pi & 150 & 545 & 10 & 1985 \\
\hline 90 & Boa Esp Sul & 752810 & 7568090 & 480 & bt/pi & 100 & 505 & 8 & 1988 \\
\hline 91 & Boa Esp Sul & 764150 & 7571840 & 473 & $\mathrm{bt} / \mathrm{pi}$ & 104 & 525 & 30 & 1994 \\
\hline
\end{tabular}




\begin{tabular}{|c|c|c|c|c|c|c|c|c|c|}
\hline No. & Cidade & $\begin{array}{l}\text { UTM-E } \\
(\mathrm{km})\end{array}$ & $\begin{array}{l}\text { UTM-N } \\
(\mathrm{km})\end{array}$ & $\begin{array}{c}\mathrm{NE} \\
\text { (m.s.n.m) }\end{array}$ & Estratigrafia & Profund. & Cota & $\mathrm{Q}(\mathrm{m} 3 / \mathrm{h})$ & $\begin{array}{c}\text { Data } \\
\text { Const/T.bomb }\end{array}$ \\
\hline 92 & Boa Esp Sul & 737570 & 7578990 & 440 & $\mathrm{bt} / \mathrm{pi}$ & 153 & 501 & 50 & 1992 \\
\hline 93 & Boa Esp Sul & 744914 & 7579611 & 446 & $\mathrm{bt} / \mathrm{pi}$ & 152 & 489 & 11 & 1988 \\
\hline 94 & Boa Esp Sul & 782800 & 7574150 & 472 & bt & 130 & 505 & 15 & 1989 \\
\hline 95 & Boa Esp Sul & 760350 & 7569050 & 491 & bt & 103 & 500 & 18 & 1985 \\
\hline 96 & Boa Esp Sul & 770800 & 7575200 & 524 & sol18;sg72;bt & 174 & 573 & 36 & 1985 \\
\hline 97 & Boa Esp Sul & 768600 & 7563914 & 498 & bt48;pi96;sil & 97 & 540 & - & - \\
\hline 98 & Bariri & 736400 & 7563050 & 448 & $\mathrm{bt} / \mathrm{pi}$ & 250 & 450 & 400 & 2004 \\
\hline 99 & Bariri & 732400 & 7558400 & 445 & bau20,sg220;bt/pi & 420 & 450 & 300 & 1989 \\
\hline 100 & Bariir & 731700 & 7556250 & 450 & ad27;sg224;bt/pi & 400 & 450 & 250 & 1988 \\
\hline 101 & Bariri & 732343 & 7557105 & 449 & bau27;sg224;bt/pi & 400 & 450 & - & - \\
\hline 102 & São Carlos & 831533 & 7589814 & 553 & bt46;sil112;bt207;sil & 208 & 640 & 30 & 1994 \\
\hline 103 & São Carlos & 816776 & 7566427 & 731 & fsc46;sg140;bt & 272 & 870 & 70 & 1999 \\
\hline 104 & São Carlos & 820999 & 7569214 & 780 & itaq17;sg47;bt & 167 & 880 & 16 & 1983 \\
\hline 105 & São Carlos & 817603 & 7565073 & 719 & itaq50;sg199;bt442;sil444;pi & 457 & 878 & 137 & 1999 \\
\hline 106 & São Carlos & 820180 & 7566443 & 742 & bau40;sg145;bt233;sil & 235 & 870 & 35 & 199 \\
\hline 107 & São Carlos & 818337 & 7564123 & 734 & bau45;sg275;bt/pi & 465 & 880 & 260 & 1992 \\
\hline 108 & São Carlos & 820171 & 7566484 & 738 & itaq36;sg146;bt230;pi & 356 & 870 & 200 & 1999 \\
\hline 109 & São Carlos & 820728 & 7567673 & 781 & bau52;sg116;bt & 226 & 885 & 12 & 1996 \\
\hline 110 & São Carlos & 814080 & 7578092 & 665 & sg140;bt & 170 & 730 & 3 & - \\
\hline 111 & São Carlos & 821207 & 7565853 & 724 & it35;sg159;bt & 210 & 845 & 15 & 1985 \\
\hline 112 & São Carlos & 821329 & 7565898 & 723 & it30;sg185;bt & 242 & 845 & 30 & 1987 \\
\hline 113 & São Carlos & 819326 & 7561272 & 726 & sol4;sg130;bt/pi & 280 & 830 & 60 & 1996 \\
\hline 114 & São Carlos & 819508 & 7561325 & 730 & bau15;sg118;bt & 130 & 830 & 7 & 1957 \\
\hline 115 & São Carlos & 823068 & 7559454 & 760 & ad60;bt & 209 & 880 & 15 & 1991 \\
\hline 116 & São Carlos & 823970 & 7557186 & 776 & bau64;sil130;bt184;sil & 187 & 818 & 40 & 1996 \\
\hline 117 & São Carlos & 823390 & 7560762 & 778 & sg52;bt/pi276;sil & 290 & 830 & 122 & 1987 \\
\hline 118 & São Carlos & 818038 & 7561863 & 711 & sg185;bt213 & 213 & 810 & 22 & 1992 \\
\hline 119 & São Carlos & 820231 & 7559865 & 752 & it23;sg78;bt196pi259;sil261;pi & 344 & 855 & 216 & 1992 \\
\hline 120 & São Carlos & 819494 & 7557142 & 735 & bt47;sil109;bt144;sil257;bt/pi & 393 & 800 & 192 & 1994 \\
\hline 121 & São Carlos & 824414 & 7559821 & 753 & it30;sg84;bt220;pi & 300 & 860 & 30 & 1995 \\
\hline 122 & São Carlos & 823269 & 7562789 & 766 & it66;sg252;bt452;sil & 484 & 910 & 265 & 1996 \\
\hline 123 & São Carlos & 821127 & 7558719 & 744 & it60;sg86;bt/pi & 292 & 850 & 118 & 1998 \\
\hline
\end{tabular}




$\begin{array}{lcccc}\text { No. } & \text { Cidade } & \begin{array}{c}\text { UTM-E } \\ (\mathrm{km})\end{array} & \begin{array}{c}\text { UTM-N } \\ (\mathrm{km})\end{array} & \begin{array}{c}\text { NE } \\ (\mathrm{m} . \text { s.n.m })\end{array} \\ 124 & \text { São Carlos } & 828943 & 7557640 & 795 \\ 125 & \text { São Carlos } & 817950 & 7561927 & 726 \\ 126 & \text { São Carlos } & 816606 & 7563956 & 711 \\ 127 & \text { São Carlos } & 821076 & 7558700 & 740 \\ 128 & \text { Amr.Brasiliense } & 808616 & 7593712 & 525 \\ 129 & \text { Rincão } & 801993 & 7608615 & 516 \\ 130 & \text { Sta Lúcia } & 803511 & 7597504 & 534 \\ 131 & \text { Amr.Brasiliense } & 801820 & 7599383 & 531 \\ 132 & \text { Ibate } & 809995 & 7566850 & 713 \\ 133 & \text { Ibate } & 808308 & 7568730 & 713 \\ 134 & \text { Nova Europ } & 750072 & 7590068 & 482 \\ 135 & \text { Nova Europ } & 750043 & 7588223 & 470 \\ 136 & \text { Boracéia } & 726968 & 7542414 & 509 \\ 137 & \text { Itapui } & 733788 & 7538621 & 447 \\ 138 & \text { Rib Bonito } & 790879 & 7557978 & 593 \\ 139 & \text { Rib Bonito } & 789124 & 7556163 & 572 \\ 140 & \text { Rib Bonito } & 790492 & 7556138 & 600 \\ 141 & \text { Jaú } & 749135 & 7530998 & 461 \\ 142 & \text { Dourado } & 766660 & 7551021 & 480 \\ 143 & \text { lacanga } & 692430 & 7578540 & 432 \\ 144 & \text { Dois correg } & 777160 & 7498710 & 436 \\ 145 & \text { Dois correg } & 776360 & 7499250 & 453 \\ 146 & \text { Dois correg } & 776800 & 7498720 & 439 \\ 147 & \text { Dois correg } & 776145 & 7499574 & 460 \\ 148 & \text { Dois correg } & 784102 & 7536230 & 510 \\ 149 & \text { Descalvado } & 840632 & 7565941 & 724 \\ 150 & \text { Descalvado } & 839731 & 7567228 & 758 \\ 151 & \text { Descalvado } & 839728 & 7568429 & 709 \\ 152 & \text { Sao Carlos } & 821918 & 7573782 & 760\end{array}$

Estratigrafia
ad60;sg147;bt/pi
sg159;bt
fsc39;sg256;bt
ita60;sg86;bt/pi292;sil
bau16;sg220;bt/pi370;sil
sg102;bt
sg133;bt
bau38;sg156;bt/pi
cen22;sg54;bt246;
pi350;sil
bau58;sg160;
sol19;sg260;bt/pi
bau28;sg213;
sol6sg212;bt
alu7;sg151;bt
bt/pi
bt19;pi
pi65;sil
sg330;bt434;pi
ad20;sg262;bt452;pi
sol40;pi
sol4;pi
sol5;pi
cen27;pi
bt/pi
sol4;sg76;bt/pi
sol48;sg222;bt;
pi286;sil
gua

$\begin{array}{cccc}\text { Profund. } & \text { Cota } & \mathrm{Q}(\mathrm{m} 3 / \mathrm{h}) & \begin{array}{c}\text { Data } \\ \text { Const/T.bomb }\end{array} \\ 243 & 945 & 40 & 1997 \\ 245 & 810 & 30 & 1996 \\ 356 & 850 & 40 & 2000 \\ 295.5 & 840 & 100 & - \\ 377 & 691 & - & - \\ 223 & 550 & - & - \\ 250 & 635 & - & - \\ 381 & 705 & - & - \\ 356 & 820 & - & - \\ 254 & 836 & - & - \\ 343 & 520 & - & - \\ 305 & 530 & - & - \\ 254 & 520 & - & - \\ 158 & 450 & - & - \\ 85 & 645 & - & - \\ 109 & 573 & - & - \\ 66 & 640 & - & - \\ 530 & 530 & - & - \\ 294 & 480 & - & - \\ 565 & 442 & 300 & 2000 \\ 154 & 470 & 11 & 2002 \\ 100 & 485 & 6 & 1983 \\ 100 & 475 & 7 & 1982 \\ 100 & 490 & 12 & 1996 \\ 66 & 510 & 3 & 1998 \\ 300 & 800 & 402 & 2003 \\ 288 & 820 & 468 & 2003 \\ 353 & 872 & 72 & 1997 \\ 90 & 780 & 5 & - \\ & & & \end{array}$


191

\begin{tabular}{|c|c|c|c|c|c|c|c|c|c|}
\hline No. & Cidade & $\begin{array}{l}\text { UTM-E } \\
(\mathbf{k m})\end{array}$ & $\begin{array}{l}\text { UTM-N } \\
\text { (km) }\end{array}$ & $\begin{array}{c}\text { NE } \\
\text { (m.s.n.m) }\end{array}$ & Estratigrafia & Profund. & Cota & $Q(m 3 / h)$ & $\begin{array}{c}\text { Data } \\
\text { Const/T.bomb }\end{array}$ \\
\hline 153 & Sao Carlos & 830421 & 7551215 & 790 & gua & 100 & 800 & 5 & - \\
\hline 154 & Sao Carlos & 820186 & 7552119 & 720 & gua & 201 & 860 & 5 & - \\
\hline 155 & Sao Carlos & 815449 & 7557130 & 705 & gua & 112 & 760 & 5 & - \\
\hline 156 & Itirapina & 828627 & 7543818 & 762 & gua & 108 & 785 & 13 & - \\
\hline 157 & Brotas & 819842 & 7534837 & 731 & gua & 58 & 740 & 3 & - \\
\hline 158 & Tabatinga & 750220 & 7602500 & 480 & gua & 240 & 580 & 34 & - \\
\hline 159 & Araraquara & 775900 & 7583500 & 505 & gua & 150 & 589 & 10 & - \\
\hline 160 & Araraquara & 776500 & 7588500 & 536 & gua & 116 & 560 & 14 & - \\
\hline 161 & Araraquara & 794750 & 7583100 & 655 & gua & 62 & 690 & 12 & - \\
\hline 162 & Ibate & 808400 & 7579110 & 618 & gua & 84 & 620 & 10 & - \\
\hline 163 & Araraquara & 801250 & 7578240 & 627 & gua & 60 & 645 & 10 & - \\
\hline 164 & Araraquara & 802600 & 7586700 & 564 & gua & 60 & 580 & 3 & - \\
\hline 165 & Trabiju & 778910 & 7563130 & 516 & gua & 104 & 520 & 36 & - \\
\hline 166 & Rib. Bonito & 784050 & 7548220 & 570 & gua & 50 & 580 & 5 & - \\
\hline 167 & Brotas & 804880 & 7534640 & 694 & gua & 147 & 700 & 3 & - \\
\hline 168 & Brotas & 796730 & 7534550 & 615 & gua & 204 & 675 & 10 & - \\
\hline 169 & Analândia & 843142 & 7557722 & 700 & gua & 100 & 750 & - & - \\
\hline 170 & Analândia & 842655 & 7550396 & 625 & gua & 90 & 700 & - & - \\
\hline
\end{tabular}


ANEXO B - Poços - dados de explotação 


\section{Aqüífero}

Frm Botucatu

Frm Botucatu

Frm Botucatu

Frm Botucatu - Pirambóia

Frm Botucatu - Pirambóia

Frm Botucatu - Pirambóia

Frm Pirambóia

Frm Serra Geral - Botucatu Frm Botucatu

Frm Botucatu - Pirambóia

Frm Botucatu - Pirambóia

Frm Botucatu - Pirambóia

Frm Botucatu - Pirambóia

Frm Botucatu - Pirambóia Frm Pirambóia

Frm Botucatu - Pirambóia

Frm Botucatu - Pirambóia

Frm Botucatu - Pirambóia

Frm Serra Geral - Botucatu Frm Botucatu

Frm Botucatu - Pirambóia

Frm Botucatu - Pirambóia

Frm Botucatu - Pirambóia

Frm Botucatu - Pirambóia

Frm Botucatu

Frm Botucatu

Frm Botucatu - Pirambóia

Frm Botucatu - Pirambóia

Frm Botucatu

Frm Botucatu

Frm Botucatu - Pirambóia

Frm Botucatu - Pirambóia

Frm Botucatu

\begin{tabular}{|c|c|c|c|c|}
\hline $\begin{array}{l}\text { UTM-E } \\
\text { (km) }\end{array}$ & $\begin{array}{l}\text { UTM-N } \\
\text { (km) }\end{array}$ & $\begin{array}{c}Q \\
(\mathrm{~m} 3 / \mathrm{h})\end{array}$ & h/dia & Dia/mês \\
\hline 794750 & 7535370 & 5.0 & 6.0 & - \\
\hline 799420 & 7566960 & 5.0 & 3.0 & - \\
\hline 763320 & 7593500 & 20.0 & 10.0 & - \\
\hline 764900 & 7576100 & 250.0 & 10.0 & - \\
\hline 777290 & 7575010 & 60.0 & 10.0 & - \\
\hline 767030 & 7565690 & 80.0 & 6.0 & - \\
\hline 790440 & 7528770 & 3.0 & 4.0 & - \\
\hline 718170 & 7587920 & 13.3 & 20.0 & - \\
\hline 765490 & 7591020 & 300.0 & 10.0 & - \\
\hline 796360 & 7590520 & 60.0 & 20.0 & - \\
\hline 737160 & 7570970 & 250.0 & 10.0 & - \\
\hline 738200 & 7563700 & 300.0 & 20.0 & - \\
\hline 767710 & 7566240 & 2.0 & 3.0 & - \\
\hline 787120 & 7581710 & 2.0 & 2.0 & - \\
\hline 792300 & 7554880 & 1.0 & 3.0 & - \\
\hline 784450 & 7571150 & - & - & - \\
\hline 789900 & 7585450 & - & - & - \\
\hline 790710 & 7558930 & - & - & - \\
\hline 789750 & 7586100 & - & - & - \\
\hline 792180 & 7554330 & - & - & - \\
\hline 739000 & 7566100 & - & - & - \\
\hline 748080 & 7587190 & - & - & - \\
\hline 769250 & 7572480 & - & - & - \\
\hline 770750 & 7550800 & - & - & - \\
\hline 793200 & 7572550 & 20.0 & 20.0 & 30.0 \\
\hline 792730 & 7553370 & - & - & - \\
\hline 771250 & 7566150 & - & - & - \\
\hline 774050 & 7538050 & - & - & - \\
\hline 738100 & 7586850 & - & - & - \\
\hline 794580 & 7584220 & - & - & - \\
\hline 791900 & 7581580 & 200.0 & - & - \\
\hline 791580 & 7583290 & 250.0 & 20.0 & 30.0 \\
\hline 769740 & 7564310 & 40,0 & - & - \\
\hline
\end{tabular}

\section{Condição}

Lic.Perfuração. Lic.Perfuração. Lic.Perfuração Lic.Perfuração. Lic.Perfuração. Lic.Perfuração. Lic.Perfuração. Impl. Autorizada Lic.Perfuração. Lic.Perfuração. Lic.Perfuração. Lic.Perfuração. Lic.Perfuração. Lic.Perfuração. Lic.Perfuração. Lic.Perfuração. Lic.Perfuração. Lic.Perfuração. Lic.Perfuração. Lic.Perfuração. Lic.Perfuração. Lic.Perfuração. Lic.Perfuração. Lic.Perfuração. Lic.Perfuração. Lic.Perfuração. Lic.Perfuração. Lic.Perfuração. Lic.Perfuração. Lic.Perfuração. Lic.Perfuração. Lic.Perfuração. Lic.Perfuração. 


\begin{tabular}{|c|c|c|c|c|c|c|c|c|}
\hline Aqüífero & $\begin{array}{c}\text { UTM-E } \\
\text { (km) }\end{array}$ & $\begin{array}{l}\text { UTM-N } \\
\text { (km) }\end{array}$ & $\begin{array}{c}Q \\
(\mathrm{~m} 3 / \mathrm{h})\end{array}$ & h/dia & Dia/mês & Usuário & Uso & Condição \\
\hline Frm Botucatu & 790000 & 7576300 & 20.0 & 20.0 & 30.0 & Público & Agric. & Lic.Perfuração. \\
\hline Frm Botucatu & 794700 & 7583950 & - & - & - & Comerciant & Sanit. & Lic.Perfuração. \\
\hline Frm Botucatu & 792660 & 7558260 & - & - & - & Público & & Lic.Perfuração. \\
\hline Frm Serra Geral - Botucatu & 792300 & 7586180 & - & - & - & Comerciant & Sanit. & Lic.Perfuração. \\
\hline Frm Botucatu & 775100 & 7560250 & - & - & - & Público & Sanit. & Lic.Perfuração. \\
\hline Frm Botucatu & 750220 & 7602500 & 34.0 & 11.0 & 30.0 & Rural & Agric. & Portaria \\
\hline Frm Botucatu & 761820 & 7594740 & 90.0 & 12.0 & 30.0 & Irrigante & Agric. & Portaria \\
\hline Frm Botucatu - Pirambóia & 794700 & 7593950 & 200.0 & 20.0 & 30.0 & Público & Ab.Publ & Portaria \\
\hline Frm Botucatu - Pirambóia & 792780 & 7595400 & 320.0 & 12.0 & 30.0 & Público & Ab.Publ & Portaria \\
\hline Frm Botucatu - Pirambóia & 797270 & 7592150 & 40.0 & 13.0 & 22.0 & Industrial & San/Ind & Portaria \\
\hline Frm Serra Geral - Botucatu & 722100 & 7586200 & 8.0 & 8.0 & - & Rural & Sanit. & Portaria \\
\hline Frm Botucatu & 744640 & 7576920 & 24.0 & 8.0 & 30.0 & Irrigante & Agric. & Portaria \\
\hline Frm Botucatu & 736650 & 7579170 & 22.0 & 8.0 & 30.0 & Irrigante & Agric. & Portaria \\
\hline Frm Botucatu & 737570 & 7578990 & 33.0 & 8.0 & 30.0 & Irrigante & Agric. & Portaria \\
\hline Frm Botucatu & 744910 & 7579610 & 22.0 & 8.0 & 30.0 & Irrigante & Agric. & Portaria \\
\hline Frm Botucatu & 740610 & 7579330 & 4.0 & 8.0 & 30.0 & Irrigante & Agric. & Portaria \\
\hline Frm Botucatu & 746150 & 7573150 & 23.0 & 8.0 & 30.0 & Irrigante & Agric. & Portaria \\
\hline Frm Botucatu & 747230 & 7571440 & 20.0 & 8.0 & 30.0 & Irrigante & Agric. & Portaria \\
\hline Frm Botucatu & 749390 & 7579590 & 13.0 & 8.0 & 30.0 & Irrigante & Agric. & Portaria \\
\hline Frm Botucatu - Pirambóia & 754720 & 7569690 & 10.0 & 2.0 & 30.0 & Rural & Agric. & Portaria \\
\hline Frm Botucatu - Pirambóia & 752810 & 7568090 & 8.0 & 3.0 & 30.0 & Rural & Agric. & Portaria \\
\hline Frm Botucatu & 775900 & 7583500 & 10.0 & 2.0 & 30.0 & Irrigante & Agric. & Portaria \\
\hline Frm Botucatu - Pirambóia & 782100 & 7590200 & 10.0 & 2.0 & - & Concession & Sanit. & Portaria \\
\hline Frm Botucatu - Pirambóia & 776500 & 7588500 & 14.0 & 2.0 & - & Rural & San/Ind & Portaria \\
\hline Frm Botucatu - Pirambóia & 769060 & 7591940 & 62.0 & 4.0 & 30.0 & Industrial & San/Ind & Portaria \\
\hline Frm Botucatu & 781770 & 7589450 & 8.9 & 4.0 & 30.0 & Rural & Sanit. & Portaria \\
\hline Frm Botucatu & 769090 & 7592250 & 80.0 & 4.0 & 30.0 & Industrial & Indust. & Portaria \\
\hline Frm Botucatu & 782900 & 7588250 & 5.5 & 2.0 & 30.0 & Concession & Sanit. & Portaria \\
\hline Frm Botucatu & 782450 & 7588250 & 5.5 & 2.0 & 30.0 & Concession & Sanit. & Portaria \\
\hline Frm Botucatu & 777910 & 7578150 & 4.0 & 1.0 & 30.0 & Rural & Sanit. & Cadastrado \\
\hline Frm Botucatu - Pirambóia & 787290 & 7587750 & 88.0 & 20.0 & - & Industrial & San/Ind & Portaria \\
\hline Frm Botucatu - Pirambóia & 794600 & 7588200 & 162.0 & 12.0 & 30.0 & Público & Ab.Publ & Portaria \\
\hline Frm Botucatu - Pirambóia & 796900 & 7590300 & 174,0 & 11,0 & 30,0 & Público & Ab.Publ & Portaria \\
\hline
\end{tabular}




\begin{tabular}{|c|c|c|c|c|c|c|c|c|}
\hline Aqüífero & $\begin{array}{l}\text { UTM-E } \\
(\mathbf{k m})\end{array}$ & $\begin{array}{l}\text { UTM-N } \\
\text { (km) }\end{array}$ & $\begin{array}{c}Q \\
(m 3 / h)\end{array}$ & h/dia & Dia/mês & Usuário & Uso & Condição \\
\hline Frm Botucatu & 792000 & 7585300 & 8.0 & 9.0 & 30.0 & Comerciant & Sanit. & Portaria \\
\hline Frm Botucatu & 794600 & 7587250 & 28.0 & 20.0 & 30.0 & Industrial & San/Ind & Portaria \\
\hline Frm Botucatu & 794650 & 7587250 & 50.0 & 20.0 & 30.0 & Industrial & San/Ind & Portaria \\
\hline Frm Botucatu & 786890 & 7585330 & 19.8 & 8.0 & - & Rural & Rural & Portaria \\
\hline Frm Botucatu - Pirambóia & 793910 & 7586650 & 175.0 & 20.0 & 30.0 & Público & Ab.Publ & Portaria \\
\hline Frm Botucatu - Pirambóia & 788600 & 7587750 & 155.0 & 20.0 & 30.0 & Público & Ab.Publ & Portaria \\
\hline Frm Botucatu - Pirambóia & 797300 & 7586250 & 180.0 & 8.0 & 30.0 & Público & Ab.Publ & Portaria \\
\hline Frm Botucatu - Pirambóia & 791200 & 7585250 & 177.0 & 18.0 & 30.0 & Público & Ab.Publ & Portaria \\
\hline Frm Botucatu - Pirambóia & 795700 & 7582000 & 330.0 & 15.0 & 30.0 & Público & Ab.Publ & Portaria \\
\hline Frm Pirambóia & 792400 & 7584200 & 250.0 & 20.0 & 30.0 & Industrial & San/Ind & Portaria \\
\hline Frm Pirambóia & 792450 & 7584800 & 250.0 & 20.0 & 30.0 & Industrial & San/Ind & Portaria \\
\hline Frm Botucatu - Pirambóia & 792650 & 7589900 & 338.0 & 19.0 & 30.0 & Público & Ab.Publ & Portaria \\
\hline Frm Botucatu & 792480 & 7585950 & 15.0 & 20.0 & - & Comunit & San/Ind & Licença Operação \\
\hline Frm Botucatu & 794650 & 7583300 & 12.0 & 20.0 & - & Industrial & Indust. & Licença Operação \\
\hline Frm Botucatu & 794750 & 7583100 & 12.0 & 20.0 & - & Industrial & San/Ind & Licença Operação \\
\hline $\begin{array}{c}\text { Serra Geral - Botucatu - } \\
\text { Pirambóia }\end{array}$ & 789500 & 7588250 & 5.0 & 20.0 & - & Outros & Sanit. & Licença Operação \\
\hline Frm Botucatu & 791700 & 7587950 & 2.0 & 20.0 & - & Avicultor & Sanit. & Portaria \\
\hline Frm Botucatu - Pirambóia & 798500 & 7588650 & 350.0 & 20.0 & 30.0 & Público & Ab.Publ & Portaria \\
\hline Frm Botucatu & 794550 & 7584300 & 12.0 & 10.0 & - & Industrial & Indust. & Portaria \\
\hline Frm Botucatu & 790700 & 7586450 & 16.5 & 20.0 & 30.0 & Outros & Sanit. & Portaria \\
\hline Frm Botucatu & 794290 & 7582600 & 6.5 & 12.0 & - & Comerciant & Sanit. & Portaria \\
\hline Frm Botucatu & 791450 & 7587320 & 15.0 & 20.0 & - & Outros & Sanit. & Portaria \\
\hline Frm Botucatu & 792400 & 7588900 & 26.0 & 4.0 & 30.0 & Industrial & San/Ind & Portaria \\
\hline Frm Botucatu & 786820 & 7584020 & 9.6 & 2.0 & - & Rural & Sanit. & Portaria \\
\hline Frm Botucatu & 788690 & 7585870 & 12.0 & 1.0 & - & Rural & Sanit. & Portaria \\
\hline Frm Botucatu & 791570 & 7580670 & 130.0 & 17.0 & - & Industrial & San/Ind & Portaria \\
\hline Frm Botucatu & 791300 & 7580590 & 60.0 & 6.0 & - & Industrial & San/Ind & Portaria \\
\hline Frm Botucatu & 791730 & 7581590 & 140.0 & 15.0 & - & Industrial & San/Ind & Portaria \\
\hline Frm Botucatu & 790970 & 7588350 & 3.2 & 3.0 & - & Outros & Sanit. & Portaria \\
\hline Frm Botucatu & 792810 & 7586430 & 160.0 & 20.0 & - & Industrial & Sanit. & Portaria \\
\hline Frm Botucatu - Pirambóia & 793900 & 7583600 & 180.0 & 20.0 & - & Irrig/Aqui & Agric. & Portaria \\
\hline Frm Botucatu - Pirambóia & 787500 & 7588000 & 150,0 & 20,0 & - & Industrial & San/Ind & Portaria \\
\hline
\end{tabular}




\begin{tabular}{|c|c|c|c|c|c|c|c|c|}
\hline Aqüífero & $\begin{array}{l}\text { UTM-E } \\
\text { (km) }\end{array}$ & $\begin{array}{c}\text { UTM-N } \\
\text { (km) }\end{array}$ & $\begin{array}{c}Q \\
(m 3 / h)\end{array}$ & h/dia & Dia/mês & Usuário & Uso & Condição \\
\hline Frm Botucatu & 790600 & 7588400 & 8.0 & 10.0 & - & Comunit & Sanit. & Portaria \\
\hline Frm Botucatu & 789310 & 7585210 & 30.0 & 11.0 & 30.0 & Público & Sanit. & Portaria \\
\hline Frm Botucatu - Pirambóia & 794150 & 7584900 & 5.0 & 10.0 & 24.0 & Industrial & San/Ind & Portaria \\
\hline Frm Botucatu & 801250 & 7578240 & 10.5 & 2.0 & 30.0 & Rural & Sanit. & Portaria \\
\hline Frm Botucatu & 794550 & 7582250 & 5.0 & 4.0 & 30.0 & Comerciant & Sanit. & Cadastrado \\
\hline Frm Botucatu - Pirambóia & 797800 & 7583150 & 350.0 & 20.0 & 30.0 & Público & Ab.Publ & Portaria \\
\hline Frm Botucatu & 784610 & 7583620 & 6.0 & 20.0 & 30.0 & Público & Sanit. & Portaria \\
\hline Frm Botucatu - Pirambóia & 784630 & 7584260 & 50.0 & 8.0 & 30.0 & Público & Agric. & Portaria \\
\hline Frm Botucatu - Pirambóia & 790010 & 7587550 & 230.0 & 20.0 & 30.0 & Público & Ab.Publ & Portaria \\
\hline Frm Botucatu & 794150 & 7583300 & 80.0 & 16.0 & 30.0 & Comerciant & San/Ind & Portaria \\
\hline Frm Botucatu & 791970 & 7587100 & 3.0 & 8.0 & 30.0 & Urbano & Sanit. & Portaria \\
\hline Frm Botucatu & 792610 & 7585820 & 6.0 & 6.0 & 30.0 & Comerciant & Sanit. & Portaria \\
\hline Frm Botucatu & 793100 & 7556000 & 2.0 & 6.0 & 30.0 & Industrial & San/Ind & Portaria \\
\hline Frm Botucatu - Pirambóia & 788090 & 7582630 & 14.4 & 2.0 & 30.0 & Industrial & San/Ind & Portaria \\
\hline Frm Botucatu & 790520 & 7586640 & 5.0 & 20.0 & 30.0 & Comunit & Sanit. & Portaria \\
\hline Frm Botucatu & 798290 & 7572860 & 4.0 & 20.0 & 30.0 & Industrial & Sanit. & Portaria \\
\hline Frm Botucatu & 792160 & 7587660 & 20.0 & 20.0 & 30.0 & Comerciant & Sanit. & Portaria \\
\hline Frm Botucatu & 793850 & 7589350 & 3.0 & 20.0 & 30.0 & Comerciant & Sanit. & Impl. Autorizada \\
\hline Frm Botucatu & 798400 & 7586080 & 1.5 & 3.0 & 30.0 & Urbano & Sanit. & Cadastrado \\
\hline Frm Botucatu - Pirambóia & 736400 & 7563050 & 400.0 & 20.0 & 30.0 & Rural & Agric. & Portaria \\
\hline Frm Botucatu & 746720 & 7553340 & 35.0 & 20.0 & 30.0 & Irrigante & Agric. & Portaria \\
\hline Frm Botucatu & 759850 & 7553480 & 8.0 & 20.0 & - & Industrial & Sanit. & Licença Operação \\
\hline Frm Botucatu & 775320 & 7559710 & 12.0 & 4.0 & - & Público & Ab.Publ & Portaria \\
\hline Frm Botucatu & 775050 & 7560450 & 99.2 & 4.0 & - & Público & Ab.Publ & Portaria \\
\hline Frm Botucatu - Pirambóia & 759790 & 7553310 & 150.0 & 20.0 & - & Industrial & Indust. & Portaria \\
\hline Frm Botucatu & 774600 & 7559750 & 2.0 & 2.0 & 30.0 & Rural & Sanit. & Portaria \\
\hline Frm Botucatu & 778910 & 7563130 & 3.6 & 1.0 & 30.0 & Rural & Sanit. & Cadastrado \\
\hline Frm Botucatu & 791550 & 7554420 & 26.0 & 1.0 & 18.0 & Rural & Sanit. & Portaria \\
\hline Frm Pirambóia & 784050 & 7548220 & 5.0 & 8.0 & 30.0 & Pecuarista & Rural & Portaria \\
\hline Frm Botucatu - Pirambóia & 784100 & 7536230 & 3.0 & 20.0 & - & Concession & Sanit. & Portaria \\
\hline Frm Botucatu & 804880 & 7534640 & 3.0 & 6.0 & - & Rural & Sanit. & Portaria \\
\hline Frm Botucatu & 798300 & 7532550 & 2.0 & 8.0 & 30.0 & Rural & Sanit. & Portaria \\
\hline Frm Botucatu & 796730 & 7534550 & 10,0 & 4,0 & 30,0 & Urbano & Sanit. & Portaria \\
\hline
\end{tabular}




\begin{tabular}{ccc}
$\begin{array}{c}\text { Aqüífero } \\
\text { Frm Pirambóia }\end{array}$ & $\begin{array}{c}\text { UTM-E } \\
(\mathbf{k m})\end{array}$ & $\begin{array}{c}\text { UTM-N } \\
\mathbf{( k m )}\end{array}$ \\
Frm Pirambóia & 796790 & 7533120 \\
Frm Botucatu - Pirambóia & 896990 & 7533150 \\
Frm Botucatu - Pirambóia & 818577 & 7537565 \\
Frm Botucatu - Pirambóia & 819326 & 7563485 \\
Frm Botucatu - Pirambóia & 817653 & 7558455 \\
Frm Botucatu & 826859 & 7552036 \\
Frm Botucatu & 819940 & 7571827 \\
Frm Botucatu & 820794 & 7559432 \\
Frm Pirambóia & 822212 & 7542850 \\
Frm Botucatu & 828800 & 7535572 \\
Frm Pirambóia & 819549 & 7549162 \\
Frm Botucatu & 821973 & 7564210 \\
Frm Botucatu - Pirambóia & 817130 & 7573699 \\
Frm Botucatu - Pirambóia & 820081 & 7566497 \\
Frm Botucatu & 831315 & 7558157 \\
Frm Botucatu - Pirambóia & 826040 & 7557414 \\
Frm Botucatu - Pirambóia & 822054 & 7565769 \\
Frm Botucatu - Pirambóia & 825429 & 7561722 \\
Frm Botucatu & 816775 & 7566426 \\
Frm Botucatu & 824542 & 7564120 \\
Frm Botucatu & 817603 & 7565073 \\
Frm Botucatu & 820179 & 7566443 \\
Frm Botucatu & 818416 & 7564120 \\
Frm Botucatu & 820171 & 7566483 \\
Frm Botucatu & 821154 & 7564503 \\
Frm Botucatu & 821207 & 7565852 \\
Frm Botucatu & 821329 & 7565897 \\
Frm Botucatu & 816404 & 7566901 \\
Frm Botucatu & 821691 & 7564662 \\
Frm Botucatu & 817953 & 7575278 \\
Frm Botucatu - Pirambóia & 822394 & 7564724 \\
Frm Botucatu & 199790 & 7572760 \\
\hline & & \\
\hline
\end{tabular}

$\begin{array}{cc}\mathbf{Q} & \text { h/dia } \\ (\mathbf{m} 3 / \mathbf{h}) & \\ 5.5 & 2.0 \\ 3.0 & 6.0 \\ 30.0 & 8.0 \\ 7.0 & 20.0 \\ 200.0 & 18.0 \\ - & - \\ - & - \\ - & - \\ - & - \\ - & - \\ - & - \\ - & - \\ - & - \\ - & - \\ - & - \\ - & - \\ - & - \\ 70.0 & - \\ 160.0 & 20.0 \\ 70.0 & 10.0 \\ 103.7 & 20.0 \\ 137.2 & 14.0 \\ 35.5 & - \\ 260.0 & 20.0 \\ 200.0 & 20.0 \\ 5.5 & 8.0 \\ 15.0 & 20.0 \\ 30.0 & 20.0 \\ 31.5 & 20.0 \\ 11.5 & 20.0 \\ 4.0 & 1.0 \\ 115.0 & 7.0 \\ - & - \\ & \end{array}$

Dia/mês
30.0
30.0
-
-
-
-
-
-
-
-
-
-
-
-
-
-
-
-
30.0
-
-
-
-
-
-
-
-
-
26.0
30.0
30.0
30.0
-

Usuário
Urbano
Condominio
Rural
Loteador
Loteador
Loteador
Rural
Rural

Uso

Sanit.

Sanit.

Rural

Sanit.

Sanit.

Sanit.

Sanit.

Comerciant

Pecuarista

Urbano

Rural

Público

Rural

Público

Loteador

Comerciant

Outros

Loteador

Público

Público

Público

Público

Público

Público

Comerciant

Industrial

Industrial

Industrial

Industrial

Rural

Industria

Condominio

Sanit.

Sanit.

Sanit.

San/Ind

Indust.

Sanit.

\section{Condição}

Portaria

Portaria

Lic.Perfuração.

Impl. Autorizada

Impl. Autorizada

Impl. Autorizada

Lic.Perfuração.

Lic.Perfuração.

Lic.Perfuração.

Lic.Perfuração.

Lic.Perfuração.

Lic.Perfuração.

Lic.Perfuração.

Lic.Perfuração.

Lic.Perfuração.

Lic.Perfuração.

Lic.Perfuração.

Lic.Perfuração.

Lic.Perfuração.

Ab.Publ

Licença Operação

Ab.Publ Licença Operação

Ab.Publ Licença Operação

Ab.Publ Licença Operação

San/Ind

San/Ind

San/Ind

Pesquis
Portaria

Portaria

Portaria

Portaria

Portaria

Portaria

Portaria

Cadastrado 


\begin{tabular}{|c|c|c|c|c|c|c|c|c|}
\hline Aqüífero & $\begin{array}{c}\text { UTM-E } \\
\text { (km) }\end{array}$ & $\begin{array}{c}\text { UTM-N } \\
\text { (km) }\end{array}$ & $\begin{array}{c}\mathrm{Q} \\
(\mathrm{m} 3 / \mathrm{h})\end{array}$ & h/dia & Dia/mês & Usuário & Uso & Condição \\
\hline Frm Botucatu & 819011 & 7572384 & 25.0 & 15.0 & 30.0 & Condominio & Sanit. & Portaria \\
\hline Frm Botucatu & 820822 & 7566508 & 60.0 & 7.0 & 30.0 & Industrial & San/Ind & Portaria \\
\hline Frm Botucatu - Pirambóia & 828952 & 7536367 & 90.0 & 20.0 & 30.0 & Público & Ab.Publ & Portaria \\
\hline Frm Botucatu & 823969 & 7557185 & 40.0 & 18.0 & 30.0 & Industrial & San/Ind & Portaria \\
\hline Frm Botucatu & 822961 & 7559027 & 40.0 & 12.0 & - & Público & Sanit. & Licença Operação \\
\hline Frm Botucatu & 821340 & 7561603 & 52.2 & 19.0 & - & Público & Ab.Publ & Licença Operação \\
\hline Frm Botucatu & 823389 & 7560762 & 122.2 & 19.0 & - & Público & Ab.Publ & Licença Operação \\
\hline Frm Botucatu & 820231 & 7559865 & 215.7 & 20.0 & - & Público & Ab.Publ & Licença Operação \\
\hline Frm Botucatu & 819493 & 7557141 & 191.7 & 19.0 & - & Público & Ab.Publ & Licença Operação \\
\hline Frm Botucatu & 824413 & 7559820 & 30.0 & 5.0 & - & Público & Ab.Publ & Licença Operação \\
\hline Frm Botucatu & 823269 & 7562788 & 264.6 & 20.0 & - & Público & Ab.Publ & Licença Operação \\
\hline Frm Botucatu & 821127 & 7558718 & 118.5 & 18.0 & - & Público & Ab.Publ & Licença Operação \\
\hline Frm Botucatu - Pirambóia & 828942 & 7557640 & 40.0 & 12.0 & - & Condominio & Sanit. & Portaria \\
\hline Frm Botucatu - Pirambóia & 820822 & 7561163 & 30.0 & 6.0 & - & Industrial & Indust. & Portaria \\
\hline Frm Botucatu & 818653 & 7561999 & 30.0 & 5.0 & - & Comerciant & Sanit. & Portaria \\
\hline Frm Botucatu - Pirambóia & 828503 & 7551821 & 5.0 & 20.0 & - & Industrial & Rural & Portaria \\
\hline Frm Botucatu & 820564 & 7562995 & 30.0 & 20.0 & - & Comunit & Sanit. & Portaria \\
\hline Frm Botucatu & 824068 & 7562246 & 12.0 & 20.0 & - & Comunit & Sanit. & Portaria \\
\hline Frm Botucatu & 821148 & 7560800 & 37.5 & 8.0 & - & Industrial & San/Ind & Portaria \\
\hline Frm Botucatu & 821112 & 7560901 & 50.0 & 6.0 & - & Industrial & San/Ind & Portaria \\
\hline Frm Botucatu & 816988 & 7559112 & 11.8 & 6.0 & - & Industrial & Sanit. & Portaria \\
\hline Frm Pirambóia & 827806 & 7558015 & 20.0 & 10.0 & - & Comerciant & Dessed & Portaria \\
\hline Frm Botucatu & 821468 & 7560016 & 16.0 & 20.0 & - & Industrial & San/Ind & Portaria \\
\hline Frm Botucatu & 821692 & 7558596 & 2.0 & 20.0 & 30.0 & Industrial & Sanit. & Portaria \\
\hline Frm Pirambóia & 830421 & 7551215 & 5.0 & 10.0 & 30.0 & Rural & Sanit. & Portaria \\
\hline Frm Botucatu - Pirambóia & 826615 & 7559554 & 10.0 & 10.0 & - & Industrial & Sanit. & Portaria \\
\hline Frm Botucatu & 822787 & 7559704 & 6.0 & 5.0 & - & Industrial & San/Ind & Portaria \\
\hline Frm Botucatu & 822914 & 7559869 & 15.0 & 4.0 & - & Industrial & San/Ind & Portaria \\
\hline Frm Botucatu & 820923 & 7560408 & 10.0 & 20.0 & 26.0 & Industrial & San/Ind & Portaria \\
\hline Frm Botucatu - Pirambóia & 825632 & 7556199 & 6.5 & 2.0 & - & Comerciant & Sanit. & Portaria \\
\hline Frm Botucatu & 822052 & 7562656 & 20.0 & 5.0 & - & Industrial & San/Ind & Portaria \\
\hline Frm Botucatu & 821935 & 7562731 & 12.0 & 8.0 & - & Industrial & San/Ind & Portaria \\
\hline Frm Botucatu - Pirambóia & 207380 & 7555290 & 4,5 & 1,0 & - & Rural L & Sanit. & Portaria \\
\hline
\end{tabular}




\begin{tabular}{|c|c|c|c|c|c|c|c|c|c|}
\hline No & Aqüífero & $\begin{array}{c}\text { UTM-E } \\
(\mathbf{k m})\end{array}$ & $\begin{array}{c}\text { UTM-N } \\
\text { (km) }\end{array}$ & $\begin{array}{c}\mathrm{Q} \\
(\mathrm{m} 3 / \mathrm{h})\end{array}$ & h/dia & Dia/mês & Usuário & Uso & Condição \\
\hline 198 & Frm Botucatu - Pirambóia & 826493 & 7554673 & 4.0 & 1.0 & 30.0 & Rural & Sanit. & Portaria \\
\hline 199 & Frm Botucatu - Pirambóia & 818125 & 7546816 & 3.0 & 10.0 & 30.0 & Rural & Sanit. & Portaria \\
\hline 200 & Frm Botucatu - Pirambóia & 817482 & 7544229 & 13.0 & 6.0 & 30.0 & Rural & Sanit. & Portaria \\
\hline 201 & Frm Botucatu & 818793 & 7554356 & 3.0 & 20.0 & 30.0 & Rural & Sanit. & Portaria \\
\hline 202 & Frm Pirambóia & 820305 & 7553106 & 5.0 & 20.0 & 30.0 & Rural & Sanit. & Portaria \\
\hline 203 & Frm Botucatu & 820186 & 7552119 & 5.0 & 20.0 & 30.0 & Rural & Sanit. & Portaria \\
\hline 204 & Frm Botucatu & 827685 & 7552424 & 2.5 & 24.0 & 30.0 & Comerciant & Sanit. & Portaria \\
\hline 205 & Frm Botucatu & 826842 & 7554650 & 3.6 & 1.0 & 30.0 & Rural & Sanit. & Portaria \\
\hline 206 & Frm Botucatu & 815449 & 7557130 & 5.0 & 4.0 & 30.0 & Outros & Sanit. & Portaria \\
\hline 207 & Frm Botucatu & 827139 & 7554568 & 1.1 & 4.0 & 30.0 & Rural & Sanit. & Cadastrado \\
\hline 208 & Frm Botucatu & 821750 & 7559805 & 5.0 & 5.0 & 30.0 & Comerciant & Sanit. & Portaria \\
\hline 209 & Frm Botucatu - Pirambóia & 821821 & 7559822 & 12.0 & 4.0 & 30.0 & Comunit & Sanit. & Portaria \\
\hline 210 & Frm Botucatu & 828741 & 7556597 & 8.0 & 5.0 & 30.0 & Rural & Sanit. & Portaria \\
\hline 211 & Frm Botucatu & 822048 & 7555940 & 5.5 & 7.0 & 30.0 & Industrial & Sanit. & Portaria \\
\hline 212 & Frm Botucatu - Pirambóia & 821759 & 7559514 & 130.0 & 20.0 & - & Público & Ab.Publ & Licença Operação \\
\hline 213 & Frm Botucatu - Pirambóia & 825398 & 7556098 & 1.3 & 6.0 & 30.0 & Outros & Sanit. & Portaria \\
\hline 214 & Frm Botucatu & 816961 & 7557401 & 5.0 & 4.0 & 30.0 & Minerador & Sanit. & Portaria \\
\hline 215 & Frm Botucatu & 823455 & 7563211 & 9.9 & 1.0 & 24.0 & Industrial & San/Ind & Portaria \\
\hline 216 & Frm Botucatu - Pirambóia & 828627 & 7543818 & 13.0 & 7.0 & 30.0 & Rural & Sanit. & Portaria \\
\hline 217 & Frm Botucatu & 821152 & 7560119 & 16.0 & 20.0 & - & Industrial & San/Ind & Portaria \\
\hline 218 & Frm Pirambóia & 828428 & 7535787 & 70.0 & 4.0 & 30.0 & Público & Ab.Publ & Portaria \\
\hline 219 & Frm Botucatu - Pirambóia & 828294 & 7535682 & 143.9 & 20.0 & 30.0 & Público & Ab.Publ & Portaria \\
\hline 220 & Frm Botucatu - Pirambóia & 817781 & 7526050 & 10.5 & 20.0 & 30.0 & Público & Ab.Publ & Portaria \\
\hline 221 & Frm Pirambóia & 831638 & 7538463 & 150.0 & 10.0 & - & Rural & Agric. & Lic.Perfuração. \\
\hline 222 & Frm Botucatu - Pirambóia & 822478 & 7560257 & - & - & - & Público & Ab.Publ & Lic.Perfuração. \\
\hline 223 & Frm Pirambóia & 819052 & 7544457 & - & - & - & Rural & Sanit. & Lic.Perfuração. \\
\hline 224 & Frm Botucatu & 822643 & 7559089 & 30.0 & 20.0 & - & Industrial & San/Ind & Portaria \\
\hline 225 & Frm Serra Geral - Botucatu & 819508 & 7561325 & 8.0 & 20.0 & - & Industrial & San/Ind & Portaria \\
\hline 226 & Frm Bauru - Serra Geral & 819383 & 7561209 & 14.2 & 20.0 & - & Industrial & San/Ind & Portaria \\
\hline 227 & Frm Botucatu & 819325 & 7561272 & 60.0 & 20.0 & - & Industrial & San/Ind & Portaria \\
\hline 228 & Frm Botucatu - Pirambóia & 823067 & 7559453 & 15.0 & 8.0 & - & Industrial & San/Ind & Portaria \\
\hline 229 & Frm Botucatu & 827054 & 7553170 & 4.0 & 3.0 & - & Comerciant & Sanit. & Portaria \\
\hline
\end{tabular}




$\begin{array}{cccccccccc}\text { No } & \text { Aqǘfero } & \begin{array}{c}\text { UTM-E } \\ \mathbf{( k m )}\end{array} & \begin{array}{c}\text { UTM-N } \\ \mathbf{( k m )}\end{array} & \begin{array}{c}\mathbf{Q} \\ (\mathbf{m} 3 \mathbf{h})\end{array} & \mathbf{h} / \mathbf{d i a} & \text { Dia/mês } & \text { Usuário } & \text { Uso } & \text { Condição } \\ 230 & \text { Frm Botucatu } & 198770 & 7562280 & 5,1 & 11,0 & 30,0 & \text { Outros } & \text { Sanit. } & \text { Portaria } \\ 231 & \text { Frm Botucatu - Pirambóia } & 819842 & 7534837 & 3.0 & 20.0 & - & \text { Concession } & \text { Sanit. } & \text { Portaria }\end{array}$

